This report was prepared as an account of work sponsored by an agency of the United States Government. Neither the United States Government nor any agency thereof, nor any of their employees, makes any warranty, express or implied, or assumes any legal liability or responsibility for the accuracy, completeness, or usefulness of any information, apparatus, product, or process disclosed, or represents that its use would not infringe privately owned rights. Reference herein to any specific commercial product, process, or service by trade name, trademark, manufacturer, or otherwise does not necessarily constitute or imply its endorsement, recommendation, or favoring by the United States Government or any agency thereof. The views and opinions of authors expressed herein do not necessarily state or reflect those of the United States Government or any agency thereof.

\title{
Idaho National Engineering Laboratory Radiological Environmental Surveillance Program 1995 Annual Report
}

\author{
Maria Miles \\ Roger N. Wilhelmsen \\ Bryan W. Borsella \\ Kelly C. Wright
}

Published August 1996

\section{Idaho National Engineering Laboratory Lockheed Martin Idaho Technologies Idaho Falls, Idaho 83415}

Prepared for the

U.S. Department of Energy Assistant Secretary for Environmental Management Under DOE Idaho Operations Office

Contract DE-AC07-94ID13223 


\section{DISCLAIMER}

Portions of this document may be illegible in electronic image products. Images are produced from the best available original document. 


\begin{abstract}
This report describes calendar year 1995 environmental surveillance activities of Environmental Monitoring and Water Resources of Lockheed Martin Idaho Technologies Company, performed at the following Waste Management Facilities: the Radioactive Waste Management Complex, the Waste Experimental Reduction Facility, the Mixed Waste Storage Facility, and two surplus facilities. Results of the sampling performed by the Radiological Environmental Surveillance Program, Site Environmental Surveillance Program, and the United States Geological Survey at these facilities are included in this report. The primary purposes of monitoring are to evaluate environmental conditions, to provide and interpret data, to verify compliance with applicable regulations or standards, and to ensure protection of human health and the environment. This report compares 1995 environmental surveillance data with U.S. Department of Energy Derived Concentration Guides and with data from previous years.
\end{abstract}




\section{SUMMARY}

During calendar year 1995, the Radiological Environmental Surveillance Program (RESP) conducted environmental surveillance at specific Waste Management Facilities at the U.S. Department of Energy Idaho National Engineering Laboratory (INEL). These facilities include the Mixed Waste Storage Facility (MWSF), the Radioactive Waste Management Complex (RWMC), and the Waste Experimental Reduction Facility (WERF). RESP also conducted environmental surveillance at two contaminated surplus facilities: the Organic-Moderated Reactor Experiment and the Stationary Low-Power Reactor No. 1 (SL-1). This report presents the results for 1995 air, water, soil, biotic, and ambient radiation monitoring activities. In addition, this report discusses current methods and monitoring programs of RESP, along with groundwater monitoring at RWMC by the United States Geological Survey (USGS).

Analysis results for samples collected at the RWMC showed an overall increase in the number of positive measurements of $\mathrm{Sr}-90$ and transuranic radionuclides in most media collected from April through September (second and third quarters). No unusual trends were noted in air and water samples collected during the first and fourth quarters. These concentrations were below action levels and most concentrations were at or near detection limits. Soil and vegetation samples are not collected during those quarters. Media collected at the other monitored facilities showed no unusual trends.

In 1995, the concentrations of gross-beta activity in airborne particulate material at the MWSF, RWMC, and WERF were below U.S. Department of Energy's Derived Concentration Guides (DCGs) for airborne release to a public area. Gamma spectrometric analyses did not detect any gamma-emitting radionuclides in airborne particulates at the MWSF, RWMC, or WERF.

There were no significant statistical differences between concentrations of gross-beta activity in airborne particulates at the RWMC and those measured at the control location (Experimental Breeder Reactor No. I). These concentrations were consistent with historical values. All air samples collected during 1995 were submitted for alpha- and beta-emitting radionuclide analysis. Airborne Sr-90 was detected in the first, third, and fourth quarter at a maximum of $0.002 \%$ of the DCG for airbome releases to the public. During the third and fourth quarter, airborne Am-241 was detected at a maximum of $0.4 \%$ of the DCG. During the third quarter, airborne Pu-238 was detected at a maximum of $0.07 \%$ of the DCG. $\mathrm{Pu}-239,-240$ was also detected in the third quarter at a maximum of $0.37 \%$ of the DCG. Ambient air samples collected in the second quarter were invalidated because of evidence of cross-contamination during analysis (see Appendix $\mathrm{A}$ for a further explanation).

Surface runoff samples were collected from the RWMC during the first, second, and fourth quarters of 1995 and submitted for gamma analysis. No man-made, gamma-emitting radionuclides were detected in these runoff samples. Also, samples were analyzed during the second quarter for specific alpha analysis. Am-241 was detected at the Surface Disposal Area (SDA), Transuranic Storage Area (TSA)-2, and TSA-4 locations. The maximum concentration represents $0.4 \%$ of the DCG in water. Pu-239, -240 was detected at the SDA and TSA-4 locations. This concentration represents $0.13 \%$ of the DCG in water. Sr-90 was also detected at SDA, TSA-3, TSA-4, and at the control location at T-12. The maximum concentration represented $0.09 \%$ of the applicable DCG.

Beginning in the fourth quarter of 1994, surface runoff was collected from WERF seepage basins on a quarterly basis and analyzed for gamma-emitting radionuclides. No man-made, gamma-emitting radionuclides were detected in any of the samples collected during 1995.

During 1995, soil samples were collected from TSA. Cs-137 was the only gamma-emitting radionuclide detected in TSA soil samples. The concentrations detected were comparable to historical 
values and are within the range of concentrations attributed to fallout. Selected soil samples were submitted for alpha- and beta-emitting radionuclide analyses. Sr-90, $\mathrm{Pu}-239,-240$, and $\mathrm{Am}-241$ were detected in soils collected at TSA. These concentrations were all less than the Environmental Concentration Guide (see Appendix D for discussion on the Environmental Concentration Guide) and were comparable to historical concentrations found in the SWEPP area.

Crested wheatgrass was collected from four of the five major areas of the RWMC. The TSA Pad was not sampled due to construction on the Pad. No man-made, gamma activity was detected in any of the samples collected. Pu-239, -240, and Am-241 were detected in the vegetation samples submitted for specific alpha analysis. These concentrations were within the range of results reported by the Radiological and Environmental Sciences Laboratory for vegetation samples collected at the RWMC. Sr-90 results were invalidated due to evidence of cross-contamination during analysis (see Appendix A). No small mammal samples were collected during 1995 because the population was not sufficient to obtain a representative sample in all five areas.

Around the current waste disposal pit and at localized areas within the SDA, thermoluminescent dosimeter (TLD) data showed exposures that were lower than those seen in 1994. This is probably a result of increased soil cover in the active disposal pit. Stations located on the east end of TSA showed an increase in exposure during 1995 and are likely to continue to increase as the TSA-Retrieval Experiment waste movement continues and the amount of waste in Type II storage buildings increases. The maximum six-month ionizing radiation exposure measured by TLDs at the RWMC have, in general, decreased over time since 1974, with the exception of the active disposal pit.

Analysis of the WERF TLD data from November 1982 to November 1995 shows that the six-month exposures measured immediately around the WERF waste storage area varied in proportion to the amount of waste stored there and in general were higher than all other exposures measured at WERF. Exposures at the WERF storage area returned to near background levels during 1995.

Surface radiation was routinely monitored at RWMC and at the SL-1 surplus facility. No areas at the RWMC exceeded $1 \mathrm{mR} / \mathrm{h}$ at $0.9 \mathrm{~m}(3 \mathrm{ft})$. No areas with levels exceeding the SL-1 administrative control limit during the spring survey $(20 \mathrm{mR} / \mathrm{h}$ gamma/beta at contact) were identified. However, a beta particle was identified that exceeded the SL-1 control limit during the fall survey and was remediated by a Radiological Control Technician supporting the survey.

The USGS wells located at the RWMC were monitored regularly for selected volatile organic compounds, specific conductance, chloride, and sodium. No maximum contaminant levels were exceeded for volatile organic compounds or radiological analyses. No positive detections of gamma-emitting radionuclides occurred in any of the wells.

Tritium was detected in three of eight RWMC wells monitored by the USGS, with a maximum concentration of less than $0.1 \%$ of the DCG. Tritium is attributed to past disposals from wastewater operations at the Idaho Chemical Processing Plant and the Test Reactor Area. The concentrations detected in 1995 were similar to results reported in previous years. Sr-90 was detected in a duplicate sample collected at Well 87 . The concentration was $2.7 \pm 0.8 \mathrm{E}-9 \mu \mathrm{Ci} / \mathrm{mL}$, which is $0.27 \%$ of the $\mathrm{DCG}$. 


\section{ACKNOWLEDGMENTS}

The authors wish to thank all of the people who contributed to the preparation of this report: Matthew R. Hankins, Curtiss Peterson, Dennis McBride, Maurice McLain, Bill Wallowingbull, Linda Hodges, and Donna Bates for assisting in sample collection and preparation; Bob Bates for data management; Teresa Meachum for contributing to the statistical sections of this report; the Radiation Measurements Laboratory and the Radiation and Environmental Measurement Systems, especially Tom C. Sorensen and Mark Huntley, for providing analyses and results; the United States Geological Survey, especially Betty Tucker and Brennon Orr, for providing the data on groundwater monitoring; Paul Ritter and Leah Street for reviewing this report; Gwenna Hill and Ralph Clark for editing this report; and Connie Bates for preparing the document. 
viii 


\section{CONTENTS}

ABSTRACT $\ldots \ldots \ldots \ldots \ldots \ldots \ldots \ldots \ldots \ldots \ldots \ldots \ldots \ldots \ldots \ldots \ldots \ldots \ldots \ldots \ldots \ldots \ldots \ldots \ldots$

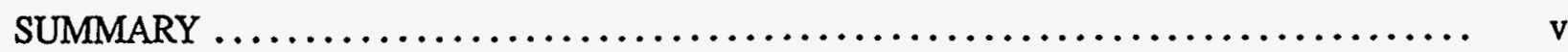

ACKNOWLEDGMENTS $\ldots \ldots \ldots \ldots \ldots \ldots \ldots \ldots \ldots \ldots \ldots \ldots \ldots \ldots \ldots \ldots \ldots \ldots \ldots \ldots \ldots$

ACRONYMS $\ldots \ldots \ldots \ldots \ldots \ldots \ldots \ldots \ldots \ldots \ldots \ldots \ldots \ldots \ldots \ldots \ldots \ldots \ldots \ldots \ldots \ldots \ldots \ldots$

1. INTRODUCTION $\ldots \ldots \ldots \ldots \ldots \ldots \ldots \ldots \ldots \ldots \ldots \ldots \ldots \ldots \ldots \ldots \ldots \ldots \ldots$

1.1 Overview of Monitoring Activities $\ldots \ldots \ldots \ldots \ldots \ldots \ldots \ldots \ldots \ldots \ldots \ldots \ldots \ldots \ldots$

1.1.1 Radiological Environmental Surveillance of Waste Management Facilities .. 3

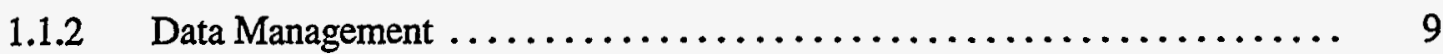

1.1.3 Quality Assurance..$\ldots \ldots \ldots \ldots \ldots \ldots \ldots \ldots \ldots \ldots \ldots \ldots \ldots \ldots$

1.1.4 Monitoring Activities Review ...................... 9

1.2 Description of Waste Management Facilities $\ldots \ldots \ldots \ldots \ldots \ldots \ldots \ldots \ldots \ldots \ldots$

1.2.1 Radioactive Waste Management Complex $\ldots \ldots \ldots \ldots \ldots \ldots \ldots \ldots \ldots$

1.2.2 Waste Experimental Reduction Facility $\ldots \ldots \ldots \ldots \ldots \ldots \ldots \ldots \ldots, \quad 12$

1.2.3 Mixed Waste Storage Facility $\ldots \ldots \ldots \ldots \ldots \ldots \ldots \ldots \ldots \ldots \ldots \ldots \ldots \ldots$

1.2.4 Stationary Low-Power No. 1 Surplus Area $\ldots \ldots \ldots \ldots \ldots \ldots \ldots \ldots$

1.2.5 Organic-Moderated Reactor Experiment $\ldots \ldots \ldots \ldots \ldots \ldots \ldots \ldots \ldots \ldots$

2. MONITORING METHODS AND RESULTS $\ldots \ldots \ldots \ldots \ldots \ldots \ldots \ldots \ldots \ldots \ldots \ldots \ldots$

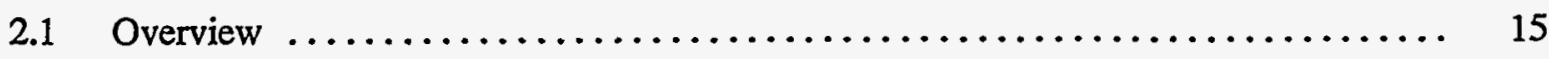

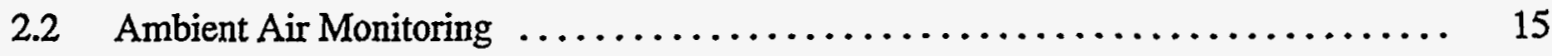

2.2.1 Air Monitoring Program Designs and Methods ............... 15

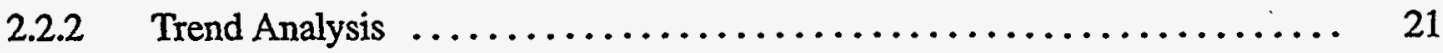

2.2.3 Comparisons by Facility $\ldots \ldots \ldots \ldots \ldots \ldots \ldots \ldots \ldots \ldots \ldots \ldots \ldots \ldots \ldots \ldots \ldots$

2.2.4 Radioactive Waste Management Complex ................. 28

2.2.5 Waste Experimental Reduction Facility $\ldots \ldots \ldots \ldots \ldots \ldots \ldots \ldots \ldots \ldots . . . \ldots \ldots$

2.2.6 Mixed Waste Storage Facility $\ldots \ldots \ldots \ldots \ldots \ldots \ldots \ldots \ldots \ldots \ldots \ldots \ldots \ldots$ 


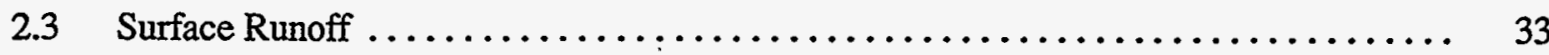

2.3.1 Radioactive Waste Management Complex $\ldots \ldots \ldots \ldots \ldots \ldots \ldots \ldots \ldots . \ldots \ldots$

2.3.2 Waste Experimental Reduction Facility $\ldots \ldots \ldots \ldots \ldots \ldots \ldots \ldots \ldots \ldots$

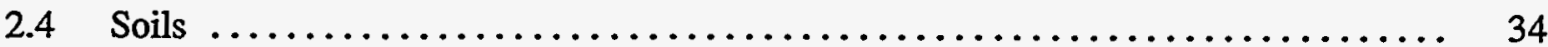

2.4.1 Radioactive Waste Management Complex .................. 38

2.4.2 Waste Experimental Reduction Facility ................... 39

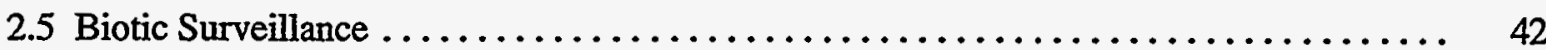

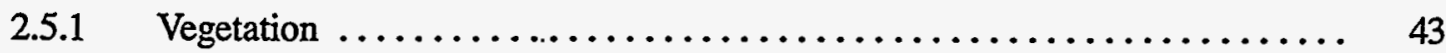

2.5.2 Radioactivity in Small Mammals $\ldots \ldots \ldots \ldots \ldots \ldots \ldots \ldots \ldots \ldots . \ldots . \ldots 4$

2.5.3 Soil Excavated by Small Mammals $\ldots \ldots \ldots \ldots \ldots \ldots \ldots \ldots \ldots \ldots . \ldots 44$

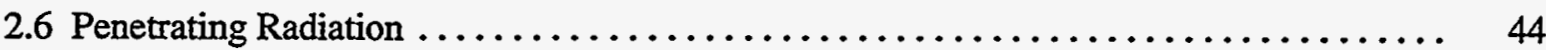

2.6.1 Trend Analysis $\ldots \ldots \ldots \ldots \ldots \ldots \ldots \ldots \ldots \ldots \ldots \ldots \ldots \ldots \ldots \ldots \ldots \ldots \ldots$

2.6.2 Statistical Comparisons by Facility $\ldots \ldots \ldots \ldots \ldots \ldots \ldots \ldots \ldots \ldots \ldots$

2.6.3 Seasonal Change $\ldots \ldots \ldots \ldots \ldots \ldots \ldots \ldots \ldots \ldots \ldots \ldots \ldots \ldots \ldots \ldots \ldots$

2.6.4 Radioactive Waste Management Complex ................... 49

2.6.5 Waste Experimental Reduction Facility $\ldots \ldots \ldots \ldots \ldots \ldots \ldots \ldots \ldots \ldots$

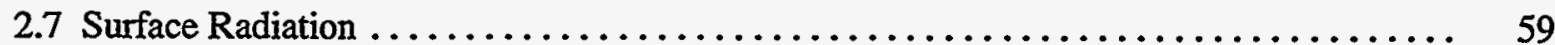

2.7.1 Radioactive Waste Management Complex ................... 59

2.7.2 Stationary Low-Power Reactor No. $1 \ldots \ldots \ldots \ldots \ldots \ldots \ldots \ldots \ldots \ldots$

2.7.3 Organic-Moderated Reactor Experiment $\ldots \ldots \ldots \ldots \ldots \ldots \ldots \ldots \ldots \ldots$

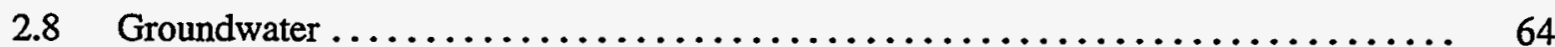

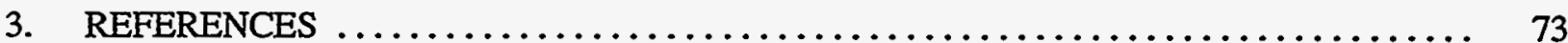

Appendix A-Quality Assurance $\ldots \ldots \ldots \ldots \ldots \ldots \ldots \ldots \ldots \ldots \ldots \ldots \ldots \ldots \ldots \ldots \ldots \ldots \ldots \ldots$

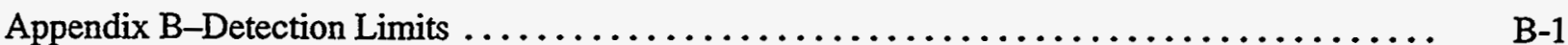

Appendix C-Statistical Analysis Methods $\ldots \ldots \ldots \ldots \ldots \ldots \ldots \ldots \ldots \ldots \ldots \ldots \ldots \ldots \ldots \ldots \ldots \ldots, \ldots \ldots$

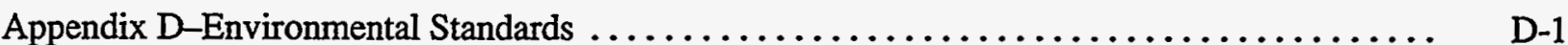




\section{FIGURES}

1. Idaho National Engineering Laboratory location map $\ldots \ldots \ldots \ldots \ldots \ldots \ldots \ldots \ldots$

2. Map of the Radioactive Waste Management Complex $\ldots \ldots \ldots \ldots \ldots \ldots \ldots \ldots \ldots$

3. Aerial photograph of the Radioactive Waste Management Complex

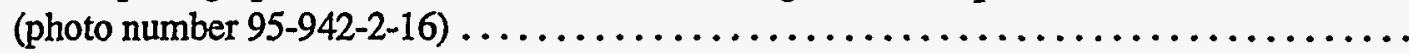

4. Aerial photograph of the Stored Waste Examination Pilot Plant

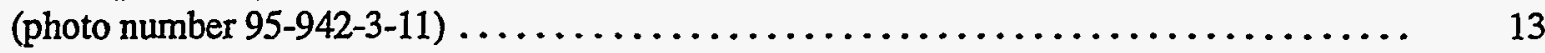

5. Aerial photograph of the Waste Experimental Reduction Facility

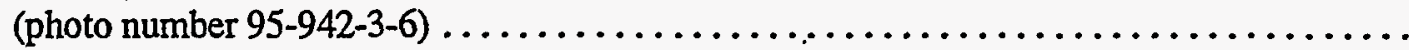

6. Collecting a particulate air filter from an SP air monitor

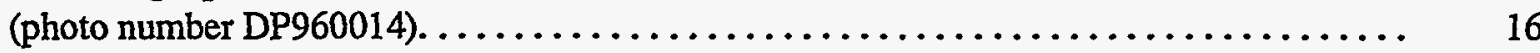

7. $\mathrm{PM}_{10}$ air monitor $\ldots \ldots \ldots \ldots \ldots \ldots \ldots \ldots \ldots \ldots \ldots \ldots \ldots \ldots \ldots \ldots \ldots \ldots \ldots \ldots \ldots \ldots \ldots \ldots \ldots \ldots$

8. Collecting a particulate air filter from a $\mathrm{PM}_{10}$ air monitor (photo number 95-309-1-1) $\ldots . \quad 18$

9. RWMC SP and $\mathrm{PM}_{10}$ air monitoring locations $\ldots \ldots \ldots \ldots \ldots \ldots \ldots \ldots \ldots \ldots \ldots \ldots \ldots$

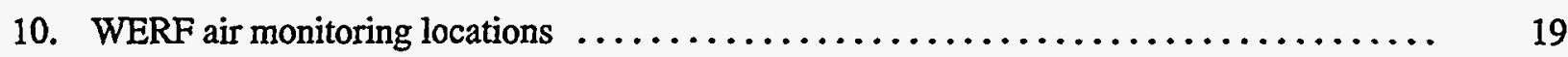

11. WERF air monitoring control location at the Main Guard Gate ............. 20

12. Gross-alpha concentrations by monitor type for Locations $2.0,20.0,26.0$, and 300 using

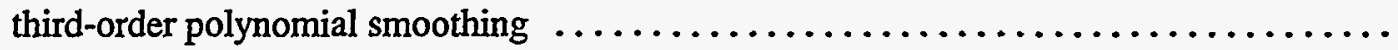

13. Gross-beta concentrations by monitor type for Locations $2.0,20.0,26.0$, and 300 using

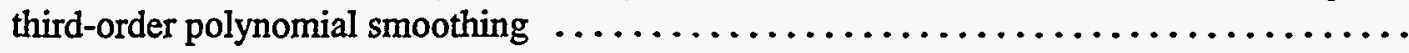

14. Gross-alpha concentrations for $\mathrm{PM}_{10}$ air monitors using second-order polynomial smoothing

15. Gross-alpha concentrations for SP air monitors using second-order polynomial smoothing

16. Gross-beta concentrations for $\mathrm{PM}_{10}$ air monitors using second-order polynomial smoothing

17. Gross-beta concentrations for SP air monitors using second-order polynomial smoothing

18. 1994 and 1995 box and whisker plots of the gross-alpha concentrations (non-outlier)

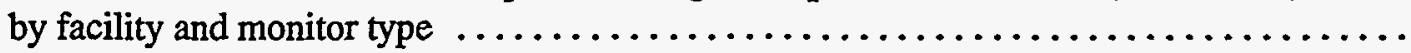

19. 1994 and 1995 box and whisker plots of the gross-beta concentrations (non-outlier) by facility and monitor type 
20. 1994 and 1995 box and whisker plots of the gross-alpha concentrations (outlier) by

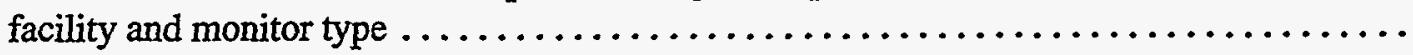

21. 1994 and 1995 box and whisker plots of the gross-beta concentrations (outlier) by

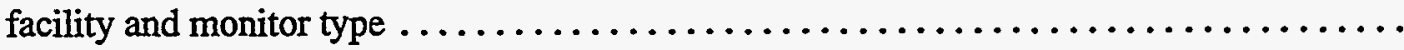

22. Quarterly averages of RWMC gross-beta air concentrations since 1985

23. Gross-beta concentration (Cs-137 equivalent) trends for SDA air filters during each semimonthly period of 1995

24. Gross-beta concentration (Cs-137 equivalent) trends for SWEPP air filters during each

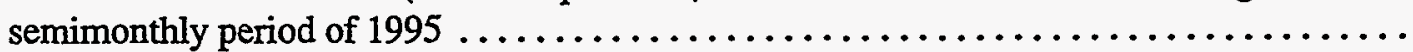

25. SESP monthly average gross-beta concentrations ( $L V$ air monitors) $\ldots \ldots \ldots \ldots \ldots \ldots$

26. Am-241 and $\mathrm{Pu}-239,-240$ quarterly composite concentrations for air filters at RWMC locations

27. Quarterly average of gross-beta air concentrations measured at WERF

28. Maximum gross-beta concentrations (Cs-137 equivalent) for WERF air filters during each semimonthly period of 1995

29. Maximum gross-beta concentrations (Cs-137 equivalent) for MWSF air filters during each semimonthly period of 1995

30. RWMC surface runoff collection (photo number $91-317-1-1) \ldots \ldots \ldots \ldots \ldots \ldots \ldots \ldots$

31. Sampling locations for surface runoff $\ldots \ldots \ldots \ldots \ldots \ldots \ldots \ldots \ldots \ldots \ldots \ldots \ldots \ldots \ldots$

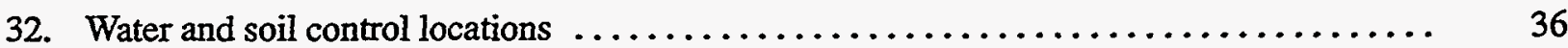

33. WERF surface runoff sampling locations $\ldots \ldots \ldots \ldots \ldots \ldots \ldots \ldots \ldots \ldots \ldots \ldots \ldots \ldots$

34. Soil sample collection (photo number $95-309-1-10) \ldots \ldots \ldots \ldots \ldots \ldots \ldots \ldots \ldots \ldots$

35. Five major areas of the RWMC used for vegetation, mammal, and soil collection ....... 39

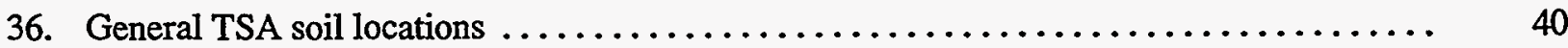

37. WERF TLD, soil, and vegetation locations $\ldots \ldots \ldots \ldots \ldots \ldots \ldots \ldots \ldots \ldots \ldots \ldots \ldots \ldots \ldots \ldots$

38. Collecting vegetation at the RWMC (photo number DP960016) $\ldots \ldots \ldots \ldots \ldots \ldots \ldots \ldots$

39. Placement of a TLD at a facility perimeter station (photo number DP960019) ....... 45

40. TLD exposure data from SDA, TSA, and WERF using negative exponential

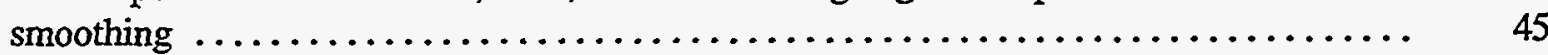

41. 1994 box and whisker plots of the TLD exposure by facility $\ldots \ldots \ldots \ldots \ldots \ldots \ldots \ldots$. 47 
42. 1995 box and whisker plots of the TLD exposure by facility $\ldots \ldots \ldots \ldots \ldots \ldots \ldots . . \ldots 7$

43. 1995 exposure trends for the spring and fall average TLD measurements ......... 48

44. 1994 exposure trend for the spring and fall average TLD measurements $\ldots \ldots \ldots \ldots .48$

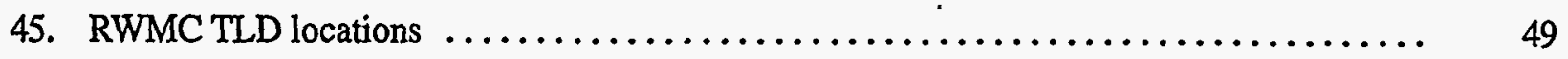

46. Six-month exposures measured by TLDs on the northwest border of the SDA ....... 50

47. Six-month exposures measured by TLDs on the northeast border of the SDA $\ldots \ldots \ldots \ldots$

48. Six-month exposures measured by TLDs on the south border of the SDA $\ldots \ldots \ldots \ldots \ldots$

49. Six-month exposures measured by TLDs on the southwest border of the SDA $\ldots \ldots \ldots \ldots$

50. Six-month exposures measured by TLDs on the southeast border of the SDA $\ldots \ldots \ldots . \quad 52$

51. Six-month exposures measured by TLDs on the west border of the SDA $\ldots \ldots \ldots \ldots \ldots . \quad 52$

52. Six-month exposures measured by two of the four TLDs on the east border of the

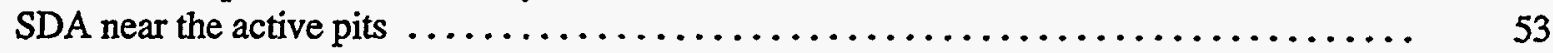

53. Six-month exposures measured by two of the four TLDs on the east border of the

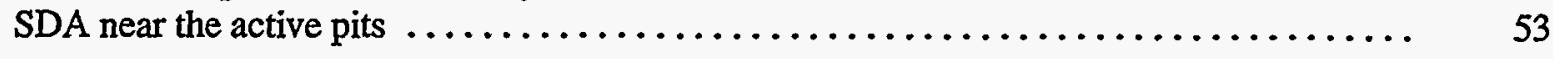

54. Six-month exposures measured by TLDs on the north border of the TSA $\ldots \ldots \ldots \ldots . \quad 56$

55. Six-month exposures measured by two of the four TLDs on the south and southeast

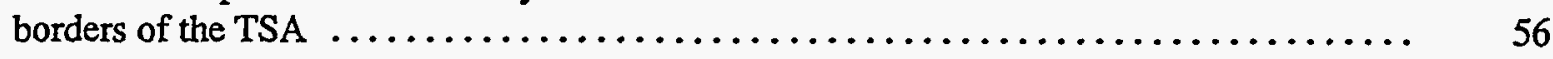

56. Six-month exposures measured by TLDs on the south border of the TSA $\ldots \ldots \ldots \ldots . \quad 57$

57. Six-month exposures measured by TLDs on the east and northeast borders of the

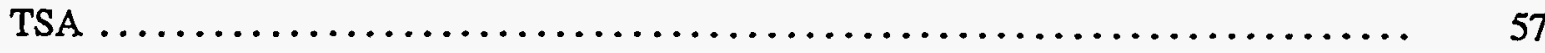

58. Six-month exposures measured by TLDs north of TSA $\ldots \ldots \ldots \ldots \ldots \ldots \ldots \ldots \ldots$

59. Six-month exposures measured by TLDs located 500 and 400 m northeast of

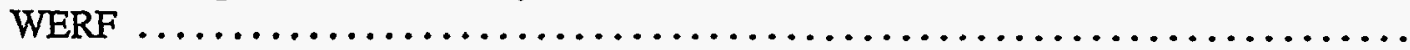

60. Six-month exposures measured by TLDs located 300 and 200 m northeast of WERF

61. Six-month exposures measured by TLDs located northeast and southeast of the 50-m

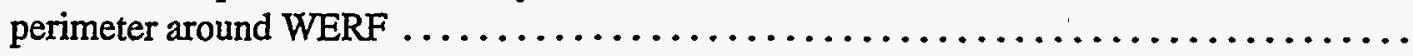

62. Six-month exposures measured by TLDs located northwest and southwest of the $50-\mathrm{m}$

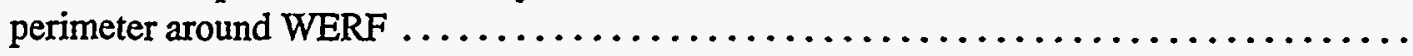

63. Six-month exposures measured by TLDs located northwest, southwest, and southeast

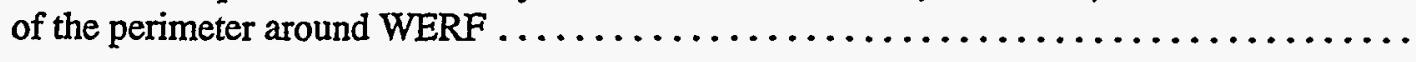


64. VRM-1 and HHD-440 meter radiation detector system (photo number DP960017) ..... 62

65. Results of 1995 spring and fall RWMC surface radiation surveys .............. 63

66. Global positioning system (photo number $92-561-1-2) \ldots \ldots \ldots \ldots \ldots \ldots \ldots \ldots \ldots$

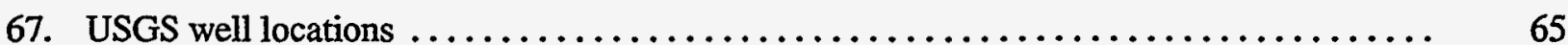

68. Carbon tetrachloride concentrations in Wells 87,88 , and $90 \ldots \ldots \ldots \ldots \ldots \ldots \ldots \ldots$

69. Tritium concentrations in RWMC Wells $\ldots \ldots \ldots \ldots \ldots \ldots \ldots \ldots \ldots \ldots \ldots \ldots \ldots \ldots \ldots \ldots \ldots \ldots$

\section{TABLES}

1. Radiological Environmental Surveillance Program activities performed at Waste

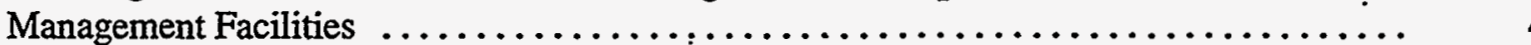

2. Summary statistics for gross-alpha concentrations $(\mathrm{E}-15 \mu \mathrm{Ci} / \mathrm{cc}) \ldots \ldots \ldots \ldots \ldots \ldots \ldots$

3. Summary statistics for gross-beta concentrations $(\mathrm{E}-15 \mu \mathrm{Ci} / \mathrm{cc}) \ldots \ldots \ldots \ldots \ldots \ldots \ldots$

4. Specific radionuclide results for TSA soils $\ldots \ldots \ldots \ldots \ldots \ldots \ldots \ldots \ldots \ldots \ldots \ldots \ldots$

5. Summary statistics for 1995 TLD 6-month exposures (all concentration values

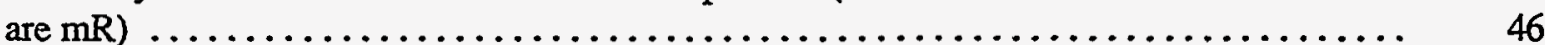

6. Results of chemical analyses of subsurface water at the RWMC in $1995 \ldots \ldots \ldots \ldots \ldots$

7. Concentrations $(\mu \mathrm{g} / \mathrm{L})$ of selected volatile organic compounds in groundwater $\ldots \ldots \ldots \ldots$

8. Results of radiochemical analyses of RWMC subsurface water $\ldots \ldots \ldots \ldots \ldots \ldots \ldots \ldots$

A-1. Results of radiochemical analysis of spiked vegetation submitted by RESP in $1995 \ldots \ldots$ A-6

A-2. Results of radiochemical analysis of air filters submitted by RESP in $1995 \ldots \ldots \ldots \ldots$ A-7

B-1. RESP samples for radiochemical analysis $\ldots \ldots \ldots \ldots \ldots \ldots \ldots \ldots \ldots \ldots \ldots \ldots \ldots \ldots \ldots$

B-2. RESP air, water, and soil samples for gamma spectrometry $\ldots \ldots \ldots \ldots \ldots \ldots \ldots \ldots$ B-5

B-3. RESP biotic samples for gamma spectrometry $\ldots \ldots \ldots \ldots \ldots \ldots \ldots \ldots \ldots \ldots \ldots \ldots$

B-4. Description of RESP samples for gamma spectrometry analysis $\ldots \ldots \ldots \ldots \ldots \ldots \ldots$ B-8

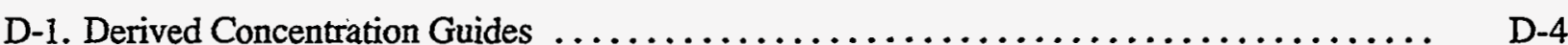

D-2. Environmental Concentration Guidelines for common radionuclides found in environmental soil samples collected at the RWMC $\ldots \ldots \ldots \ldots \ldots \ldots \ldots \ldots \ldots \ldots \ldots \ldots$

D-3. Standards for volatile organic compounds $\ldots \ldots \ldots \ldots \ldots \ldots \ldots \ldots \ldots \ldots \ldots \ldots \ldots \ldots \ldots$

D-4. Applicable radiological drinking water standards $\ldots \ldots \ldots \ldots \ldots \ldots \ldots \ldots \ldots \ldots \ldots \ldots \ldots$ 


\title{
ACRONYMS
}

\author{
ANL-W Argonne National Laboratory-West \\ ARA Auxiliary Reactor Area \\ C\&S Certified and Segregated Waste Storage \\ CFA Central Facilities Area \\ CFR Code of Federal Regulations \\ CV coefficient of variation \\ DCG Derived Concentration Guide \\ DOE U.S. Department of Energy \\ DOE-ID U.S. Department of Energy Idaho Operations Office \\ DQO data quality objectives \\ EBR-I Experimental Breeder Reactor No. I \\ EFS Experimental Field Station \\ ESP Environmental Surveillance Program \\ ESRP Eastern Snake River Plain
}

FAAT Federal Aviation Administration Tower

ICPP Idaho Chemical Processing Plant

INEL Idaho National Engineering Laboratory

LLW low-level radioactive waste

LV low-volume

MAR Monitoring Activities Review

MCL maximum contaminant level

MWSF Mixed Waste Storage Facility

NRF Naval Reactors Facility

NRTS National Reactor Testing Station

OMRE Organic-Moderated Reactor Experiment

PBF Power Burst Facility

PER Power Excursion Reactor

$\mathrm{PM}_{10} \quad$ particulate matter $\leq 10 \mu \mathrm{m}$

QA quality assurance

QC quality control

RESL Radiological and Environmental Sciences Laboratory

RESP Radiological Environmental Surveillance Program

RML Radiation Measurements Laboratory

RWMC Radioactive Waste Management Complex 
SDA Subsurface Disposal Area

SESP Site Environmental Surveillance Program

SL-1 Stationary Low-Power Reactor No. 1

SP suspended particulate

SPERT Special Power Excursion Reactor Test

SWEPP Stored Waste Examination Pilot Plant

TAN Test Area North

TLD thermoluminescent dosimeter

TRA Test Reactor Area

TRU transuranic

TSA Transuranic Storage Area

USGS United States Geological Survey

VOC volatile organic compound

VRM-1 vehicle-mounted roadway monitor number one

WERF Waste Experimental Reduction Facility

WIPP Waste Isolation Pilot Plant 


\section{Annual Report-1995 \\ Environmental Surveillance for Waste Management Facilities at the Idaho National Engineering Laboratory}

\section{INTRODUCTION}

The Idaho National Engineering Laboratory (INEL) was founded in 1949 as the National Reactor Testing Station (NRTS) to provide an isolated location where various kinds of nuclear reactors and support facilities could be built and tested. The testing programs primarily demonstrated that nuclear power could be used safely for generating electricity and for other peaceful uses. Three of the nation's commercial power reactor designs - the pressurized water reactor, the boiling water reactor, and the liquid metal-cooled breeder reactor-were first demonstrated at the INEL. Fifty-two test reactors were constructed at the INEL over the years, and most were phased out when they completed their mission. In 1974, the NRTS was named a national engineering laboratory to reflect the expanding applications of applied science and engineering capabilities to non-nuclear research. The INEL is owned by the U.S. Department of Energy (DOE), and Lockheed Martin Idaho Technologies Company is the prime contractor.

The INEL, located on the Eastern Snake River Plain (ESRP) in southeastern Idaho, covers approximately $2,300 \mathrm{~km}^{2}\left(890 \mathrm{mi}^{2}\right)$ of typical western sagebrush flats almost $1.6 \mathrm{~km}$ (1 mile) above sea level. The land is bordered on the north and west by three mountain ranges and on the south by three towering buttes. Air masses entering the ESRP from any direction have first crossed a mountain barrier, and precipitated a large percentage of moisture contained in the air. Average precipitation is $22 \mathrm{~cm}$ (8.7 in) with maximum levels occurring in winter and late spring. Thus, the region exhibits semiarid characteristics. The local northeast-southwest orientation of the ESRP and the bordering mountain ranges tend to channel the prevailing west winds so that a southwest wind (daytime) predominates over the INEL. The second-most frequent winds (nighttime) come from the northeast. The region's relatively dry air and infrequent low clouds permit intense solar heating of the surface during the day and rapid cooling at night. These factors combine to give a large diurnal range of temperatures near the ground. Because of the moderating influence of the Pacific Ocean, most of the air masses flowing over this area are usually warmer during winter and cooler in the summer than air masses flowing at a similar latitude east of the Continental Divide. The Centennial and Bitterroot Mountain ranges keep most of the shallow, but intensely cold winter air masses from entering the ESRP when they move southward from Canada. Occasionally, cold air spills over the mountains. When this happens, the cold air is held in the ESRP by the surrounding mountains, and the INEL experiences low temperatures for periods lasting a week or longer. The annual average temperature is $5.6^{\circ} \mathrm{C}\left(42.1^{\circ} \mathrm{F}\right)$, with recorded extremes of -43.9 and $39.4^{\circ} \mathrm{C}\left(-47.0\right.$ and $\left.102.9^{\circ} \mathrm{F}\right) .^{1}$

Subsurface geology at the INEL consists of successive layers of basalt and sedimentary strata, overlaid at the surface by wind- and water-deposited sediments. The primary groundwater source in the region is the Eastern Snake River Plain Aquifer. Most of the INEL is located in the Mud Lake-Lost River Basin (Pioneer Basin), which is a closed drainage basin. Surface water within the Pioneer Basin includes that from the Big Lost River, Birch Creek, and Little Lost River, all of which drain mountain watersheds located to the north and northwest of the INEL. Local rainfall and snowmelt contribute to 
surface water, mainly during the spring months. In high-flow years, the surface water can flow onto the site in any of the three surface water drainages (i.e., Big Lost River, Birch Creek, and Little Lost River). Birch Creek flows into the Birch Creek Playa on the north end of the INEL. The portion of the inflowing water that is not lost to evapotranspiration infiltrates into the subsurface. The Little Lost River flows onsite during high-flow years, and a portion infiltrates into the subsurface. Both aquifer and surface waters are used for irrigation outside the INEL. The Eastern Snake River Plain Aquifer is used as a drinking water source both on and off the INEL.

INEL soils are derived from silicic volcanic and Paleozoic sedimentary rocks from nearby mountains and buttes and are underlain by basalt. Basalt outcrops are common. Soils in the southern part of the INEL are gravelly to rocky and generally shallow. In general, INEL soils have formed as a result of alluvial or aeolian deposition over basaltic lava flows.

The INEL lies within an area designated as a sagebrush ecosystem. This broad ecosystem occupies vast plains and plateaus created from lava flows, ancient lake beds, and broad basins of alluvium. It is characterized by shrubs with an understory of perennial grasses and herbs. The flora in areas surrounding the waste management areas are typical of those found elsewhere on the INEL. ${ }^{2}$ The dominant and most conspicuous plant on the INEL is sagebrush, which covers approximately $80 \%$ of the area. Crested wheatgrass seedings are also found throughout the INEL and have existed for 25 or more years, with little evidence of re-invasion by native species. Limited dispersal from the native community and abundant seed production by the crested wheatgrass perpetuate this community. Areas occupied by crested wheatgrass support a lower density of birds, mammals, and reptiles than do areas dominated by sagebrush. 3,4

Thirty-nine species of mammals are found on the INEL, 18 of which are rodents. The Townsend's ground squirrel, least chipmunk, Great Basin pocket mouse, Ord's kangaroo rat, and montane vole are the most common small mammals on the site. These rodents are relatively common throughout sagebrush regions of the Intermountain West. Game species such as sage grouse and antelope are frequently seen in these areas.

In 1994, the U.S. Department of Energy Idaho Operations Office (DOE-ID) divided the Radiological and Environmental Sciences Laboratory-Environmental Surveillance Program (RESL-ESP) into two programs, offsite and onsite, and transferred the operation of the two parts to contractors. The offsite program and all ecological and radioecological research previously performed by the Environmental Sciences Branch of RESL was officially transferred to the Environmental Science and Research Foundation on April 5, 1994. On January 1, 1994, the onsite program [Site Environmental Surveillance Program (SESP)] was transferred to the EG\&G Idaho Environmental Monitoring Program as an interim measure until Lockheed Martin Idaho was awarded the contract to operate the INEL on October 1, 1994. These two contractor-operated programs comprise the INEL-ESP. To ensure a smooth transition of the two portions of the RESL-ESP with minimal data discontinuities, the successor contractors (Environmental Science and Research Foundation and Lockheed Martin Idaho) continued sampling in the same manner and at the same locations as the RESL-ESP through the end of calendar year 1995.

The Radiological Environmental Surveillance Program (RESP) activities are structured to support DOE-ID in maintaining an integrated INEL environmental monitoring program. The National Oceanic and Atmospheric Administration cooperates with DOE on a meteorology monitoring network. The United States Geological Survey (USGS) routinely monitors groundwater at the INEL, including wells in and adjacent to waste management areas. 
RESP, conducted by the Environmental Monitoring and Water Resources Unit, has the following general objectives: (a) provide indications of confinement integrity at radioactive waste storage and disposal facilities, (b) ensure compliance with applicable requirements regarding environmental surveillance of radioactivity at DOE Waste Management Facilities, (c) identify trends in concentrations of radioactivity in environmental media near INEL Waste Management Facilities, (d) make monitoring data available to other programs conducting activities such as performance assessments, pathways analyses, and dose estimations.

These stated program objectives are to be interpreted as including the program objectives identified in DOE Order 5400.1, Chapter IV; and DOE Order 5820.2A, Chapter II; for environmental surveillance of DOE Waste Management facilities. ${ }^{5,6}$

\subsection{Overview of Monitoring Activities}

\subsubsection{Radiological Environmental Surveillance of Waste Management Facilities}

A comprehensive radiological monitoring program is conducted at INEL Waste Management Facilities. This program includes routine and special studies of radioactive materials in air, water, soil, and biota (vegetation and small mammals) and ambient radiation monitoring (see Table 1).

The Waste Management Facilities monitored by RESP at the INEL (see Figure 1) include the Mixed Waste Storage Facility (MWSF), the Organic-Moderated Reactor Experiment (OMRE) area, Radioactive Waste Management Complex (RWMC), the Stationary Low-Power Reactor No. 1 (SL-1) surplus area, and the Waste Experimental Reduction Facility (WERF).

The RWMC is used to dispose of low-level radioactive waste (LLW) and to store transuranic (TRU) waste received from the INEL and other DOE sites. Other waste management activities normally conducted at the MWSF, and WERF include waste reduction and incineration, mixed waste storage, TRU waste certification and processing, research, and technology development.

Airborne transport is the most likely near-term pathway for radionuclide migration from the active RWMC and WERF facilities. Consequently, more extensive air monitoring is conducted at these facilities to detect airborne transport of radionuclides.

Surface water runoff sampling is conducted quarterly at the RWMC and WERF if sufficient water is available. The resulting samples are analyzed to determine radionuclide concentrations in runoff and to determine if radionuclide transport from the area is possible during runoff conditions. Generally, runoff does not flow from the RWMC except during rapid snowmelt or after heavy rainfalls.

RESP is responsible for routine soil monitoring at the RWMC and WERF. A preliminary assessment of surface soils was conducted at all EG\&G Idaho-operated facilities during 1989 . The SESP is responsible for conducting periodic soil monitoring outside the RWMC and WERF. Soil sampling and analysis help determine whether RWMC and WERF operations contribute to soil contamination and help determine long-term trends. Surface soils that have not been recontoured at the RWMC demonstrate radionuclide levels slightly above background due either to past transportation and handling of radioactive wastes, past flooding, or migration from buried waste. ${ }^{7}$ Surface soils at WERF could possibly become contaminated by deposition of radionuclides in airborne effluents or as a result of radioactive waste handling. 
Table 1. Radiological Environmental Surveillance Program activities performed at Waste Management Facilities.

\begin{tabular}{|c|c|c|c|c|}
\hline Facility & $\begin{array}{c}\text { Sample } \\
\text { type/measurement }\end{array}$ & Description & Frequency of analysis & Type of analysis \\
\hline \multicolumn{5}{|l|}{ RWMC } \\
\hline \multirow[t]{9}{*}{ SDA } & Air & & & \\
\hline & - $\mathrm{PM}_{10} \mathrm{a}^{\mathrm{a}}$ & $\begin{array}{l}8 \text { air monitors operated at } 0.11 \mathrm{~m}^{3} / \mathrm{min} \\
\text { (includes } 1 \text { control and } 1 \text { replicate) }\end{array}$ & $\begin{array}{l}\text { Semimonthly } \\
\text { Semimonthly } \\
\text { Monthly } \\
\text { Quarterly }\end{array}$ & $\begin{array}{l}\text { Gross alpha } \\
\text { Gross beta } \\
\text { Gamma spectrometry } \\
\text { Radiochemistryb }\end{array}$ \\
\hline & $\begin{array}{l}\text { - Suspended } \\
\text { Particulate }\end{array}$ & 1 air monitor operated at $0.14 \mathrm{~m}^{3} / \mathrm{min}$ & $\begin{array}{l}\text { Semimonthly } \\
\text { Semimonthly } \\
\text { Monthly } \\
\text { Quarterly }\end{array}$ & $\begin{array}{l}\text { Gross alpha } \\
\text { Gross beta } \\
\text { Gamma spectrometry } \\
\text { Radiochemistryb }\end{array}$ \\
\hline & Surface Water & One 4-L sample from SDA and control location & $\begin{array}{l}\text { Quarterly, but depends } \\
\text { on precipitation }\end{array}$ & $\begin{array}{l}\text { Gross alpha } \\
\text { Gross beta } \\
\text { Gamma spectrometry } \\
\text { Radiochemistryb,c,d }\end{array}$ \\
\hline & $\begin{array}{l}\text { Groundwater } \\
\text { (sampled by the USGS) }\end{array}$ & 2-L samples from each of 6 wells & $\begin{array}{l}65-\mathrm{m} \text { well annually, } 183-\mathrm{m} \\
\text { wells quarterly, Production well } \\
\text { monthly }\end{array}$ & $\begin{array}{l}\text { Gamma spectrometry } \\
\mathrm{H}-3, \mathrm{Sr}-90, \mathrm{Pu}-238 \\
\mathrm{Pu}-239,-240, \mathrm{Am}-241 \\
\text { Specific conductance } \\
\text { Chloride, sodium, nitrate }\end{array}$ \\
\hline & Direct Radiation & & & \\
\hline & - Surface gamma activity & Truck-mounted VRM-1 detector system & Semiannually & External radiation levels \\
\hline & $\begin{array}{l}\text { - Ionizing Radiation } \\
\text { (conducted by RESP } \\
\text { and SESP) }\end{array}$ & $\begin{array}{l}15 \text { TLD packets (SESP), } 4 \text { TLD packets (RESP) } \\
\text { and } 7 \text { background communities (SESP/ESRF) }\end{array}$ & Semiannually & $\begin{array}{l}\text { External radiation } \\
\text { levels }\end{array}$ \\
\hline & Small Mammal & $\begin{array}{l}3 \text { composites in each of } 5 \text { major areas (plus } 1 \text { control } \\
\text { area) }\end{array}$ & $\begin{array}{l}\text { Annually, but species } \\
\text { sampled varies each year } \\
\text { depending on availability }\end{array}$ & $\begin{array}{l}\text { Gamma spectrometry } \\
\text { Radiochemistryb }\end{array}$ \\
\hline
\end{tabular}


Table 1. (continued).

\begin{tabular}{|c|c|c|c|c|}
\hline Facility & $\begin{array}{c}\text { Sample } \\
\text { type/measurement } \\
\end{array}$ & Description & Frequency of analysis & Type of analysis \\
\hline & Soil & $\begin{array}{l}5 \text { surface locations in each of } 5 \text { major areas } \\
\text { (plus } 1 \text { control area) }\end{array}$ & Triennially & $\begin{array}{l}\text { Gamma spectrometry } \\
\text { Radiochemistryb }\end{array}$ \\
\hline & Vegetation & $\begin{array}{l}3 \text { composites in each of } 5 \text { major areas (plus } 1 \text { control } \\
\text { area) }\end{array}$ & $\begin{array}{l}\text { Annually, but species } \\
\text { sampled varies each } \\
\text { year as determined by availability }\end{array}$ & $\begin{array}{l}\text { Gamma spectrometry } \\
\text { Radiochemistryb }\end{array}$ \\
\hline & Visual Inspection & Tour SDA and TSA & Monthly & $\begin{array}{l}\text { Results reported for any } \\
\text { required corrective action }\end{array}$ \\
\hline \multirow[t]{8}{*}{ SWEPP } & Air & & & \\
\hline & - $\mathrm{PM}_{10}{ }^{\mathrm{a}}$ & 5 air monitors operated at $0.11 \mathrm{~m}^{3} / \mathrm{min}$ & $\begin{array}{l}\text { Semimonthly } \\
\text { Semimonthly } \\
\text { Monthly } \\
\text { Quarterly }\end{array}$ & $\begin{array}{l}\text { Gross alpha } \\
\text { Gross beta } \\
\text { Gamma spectrometry } \\
\text { Radiochemistryb }\end{array}$ \\
\hline & - Suspended & 2 air monitors operated at $0.14 \mathrm{~m}^{3} / \mathrm{min}$ & $\begin{array}{l}\text { Semimonthly } \\
\text { Semimonthly } \\
\text { Monthly } \\
\text { Quarterly }\end{array}$ & $\begin{array}{l}\text { Gross alpha } \\
\text { Gross beta } \\
\text { Gamma spectrometry } \\
\text { Radiochemistryb }\end{array}$ \\
\hline & Surface Water & $\begin{array}{l}\text { One 4-L sample from TSA-1, TSA-2, TSA-3, } \\
\text { TSA-4, and control locations }\end{array}$ & $\begin{array}{l}\text { Quarterly, but depends } \\
\text { on precipitation }\end{array}$ & $\begin{array}{l}\text { Gross alpha } \\
\text { Gross beta } \\
\text { Gamma spectrometry } \\
\text { Radiochemistryb }\end{array}$ \\
\hline & Soil & 9 locations sampled (plus 2 control areas) & Triennially & $\begin{array}{l}\text { Gamma spectrometry } \\
\text { Radiochemistryb }\end{array}$ \\
\hline & \multicolumn{4}{|l|}{ Direct Radiation } \\
\hline & $\begin{array}{l}\text { - Surface gamma } \\
\text { activity }\end{array}$ & Truck-mounted VRM-1 detector system & Semiannually & External radiation levels \\
\hline & $\begin{array}{l}\text { - Ionizing radiation } \\
\text { (conducted by RESP } \\
\text { and SESP) }\end{array}$ & $\begin{array}{l}9 \text { TLD packets (SESP), } 3 \text { TLD packets (RESP) } \\
\text { and } 7 \text { background communities (SESP/ESRF) }\end{array}$ & Semiannually & $\begin{array}{l}\text { External radiation } \\
\text { levels }\end{array}$ \\
\hline
\end{tabular}


Table 1. (continued).

\begin{tabular}{|c|c|c|c|c|}
\hline Facility & $\begin{array}{c}\text { Sample } \\
\text { type/measurement }\end{array}$ & Description & Frequency of analysis & Type of analysis \\
\hline \multirow[t]{7}{*}{ WERF } & Air & & & \\
\hline & - $\mathrm{PM}_{10} \mathrm{a}^{\mathrm{a}}$ & $\begin{array}{l}3 \text { air monitors operated at } 0.11 \mathrm{~m}^{3} / \mathrm{min} \\
\text { (includes } 1 \text { control) }\end{array}$ & $\begin{array}{l}\text { Semimonthly } \\
\text { Semimonthly } \\
\text { Monthly }\end{array}$ & $\begin{array}{l}\text { Gross alpha } \\
\text { Gross beta } \\
\text { Gamma spectrometry }\end{array}$ \\
\hline & $\begin{array}{l}\text { - Suspended } \\
\text { Particulate }\end{array}$ & 1 air monitor operated at $0.14 \mathrm{~m}^{3} / \mathrm{min}$ & $\begin{array}{l}\text { Semimonthly } \\
\text { Semimonthly } \\
\text { Monthly }\end{array}$ & $\begin{array}{l}\text { Gross alpha } \\
\text { Gross beta } \\
\text { Gamma spectrometry }\end{array}$ \\
\hline & Direct Radiation & & & \\
\hline & $\begin{array}{l}\text { - Ionizing radiation } \\
\text { conducted by RESP } \\
\text { and SESP }\end{array}$ & $\begin{array}{l}11 \text { TLD packets (RESP) and } 7 \text { background } \\
\text { communities (SESP/ESRF) }\end{array}$ & Semiannually & $\begin{array}{l}\text { External radiation } \\
\text { levels }\end{array}$ \\
\hline & $\begin{array}{l}\text { Soil } \\
\text { - Surface Soils } \\
\text { - Seepage Basins }\end{array}$ & $\begin{array}{l}15 \text { surface locations } \\
3 \text { locations }\end{array}$ & $\begin{array}{l}\text { Trienniallye } \\
\text { Annually }\end{array}$ & $\begin{array}{l}\text { Gamma spectrometrye } \\
\text { Gamma spectrometry }\end{array}$ \\
\hline & Vegetation & 15 locations (includes 3 controls) & Triennially & Gamma spectrometry \\
\hline \multirow[t]{2}{*}{ MWSF } & Air & & & \\
\hline & - $\mathrm{PM}_{10} \mathrm{a}^{\mathrm{a}}$ & 1 air monitor operated at $0.11 \mathrm{~m}^{3} / \mathrm{min}$ & $\begin{array}{l}\text { Semimonthly } \\
\text { Semimonthly } \\
\text { Monthly }\end{array}$ & $\begin{array}{l}\text { Gross alpha } \\
\text { Gross beta } \\
\text { Gamma spectrometry }\end{array}$ \\
\hline \multirow[t]{3}{*}{ SL-1 } & Direct Radiation & & & \\
\hline & $\begin{array}{l}\text { - Surface gamma } \\
\text { activity }\end{array}$ & Hand-held HHD-440 & Semiannually & $\begin{array}{l}\text { External radiation } \\
\text { levels }\end{array}$ \\
\hline & Visual Inspection & Tour SL-1 & Semiannually & $\begin{array}{l}\text { Results reported for any } \\
\text { required corrective action }\end{array}$ \\
\hline
\end{tabular}


Table 1. (continued).

\begin{tabular}{|c|c|c|c|c|}
\hline Facility & $\begin{array}{c}\text { Sample } \\
\text { type/measurement }\end{array}$ & Description & Frequency of analysis & Type of analysis \\
\hline \multirow[t]{3}{*}{ OMRE } & Direct Radiation & & & \\
\hline & $\begin{array}{l}\text { - Surface gamma } \\
\text { activity }\end{array}$ & Truck-mounted detector system & Annually & External radiation levels \\
\hline & Visual Inspection & Tour OMRE & Annually & $\begin{array}{l}\text { Results reported for any } \\
\text { required corrective action }\end{array}$ \\
\hline \multicolumn{5}{|c|}{$\begin{array}{l}\text { a. } \mathrm{PM}_{10} \text { air monitoring started in July } 1992 \text {. } \\
\text { b. Analysis for Am-241, Pu-238, Pu-239,-240, U-235, U-238, and Sr-90, } \\
\text { c. Samples for radiochemical analyses usually taken during second quarter only. } \\
\text { d. Exact number of samples may vary, due to availability. } \\
\text { e. Sampling frequency may vary if air radioactivity levels increase. }\end{array}$} \\
\hline
\end{tabular}




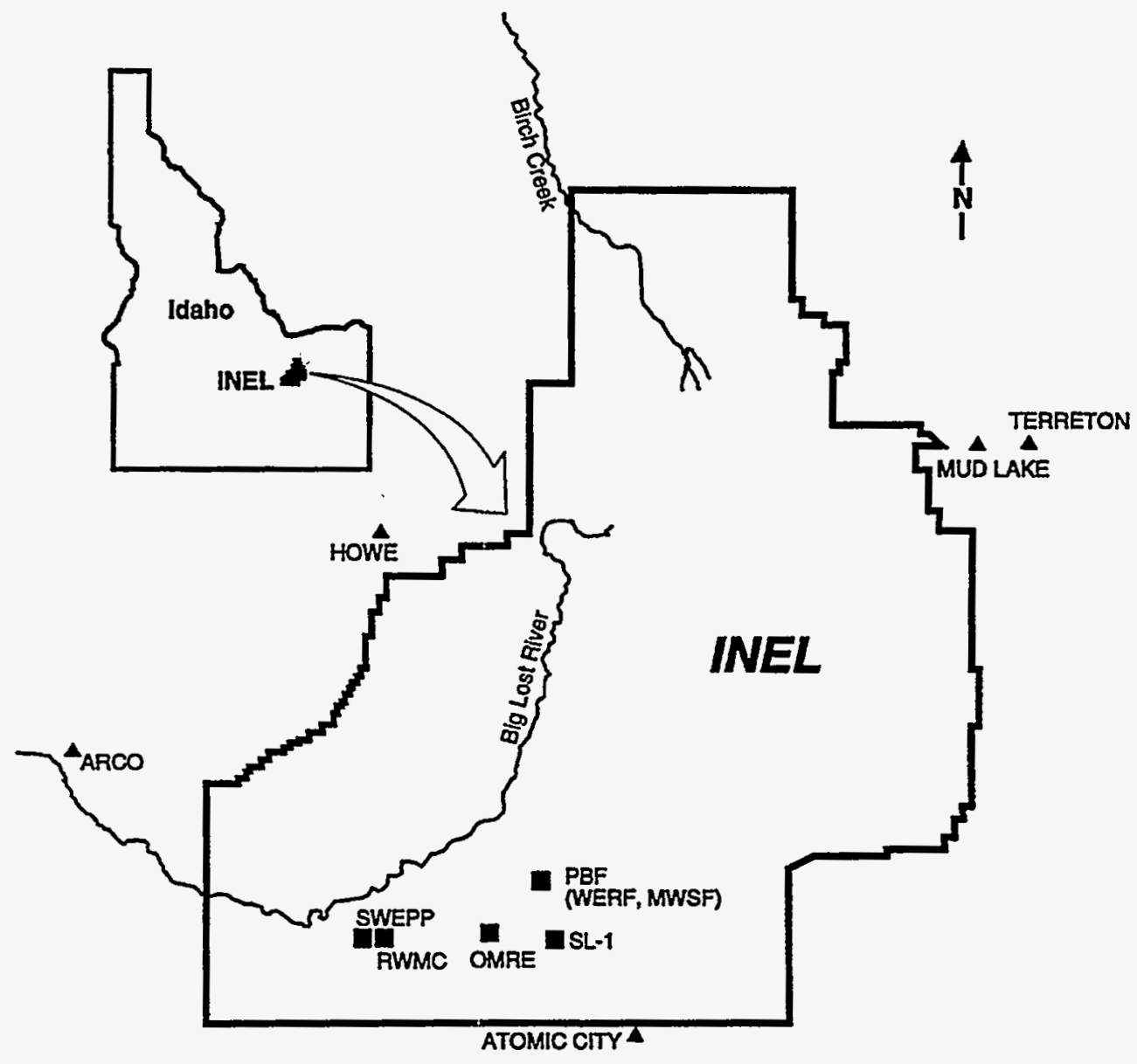

Selected Facilities at the Idaho National Engineering Laboratory

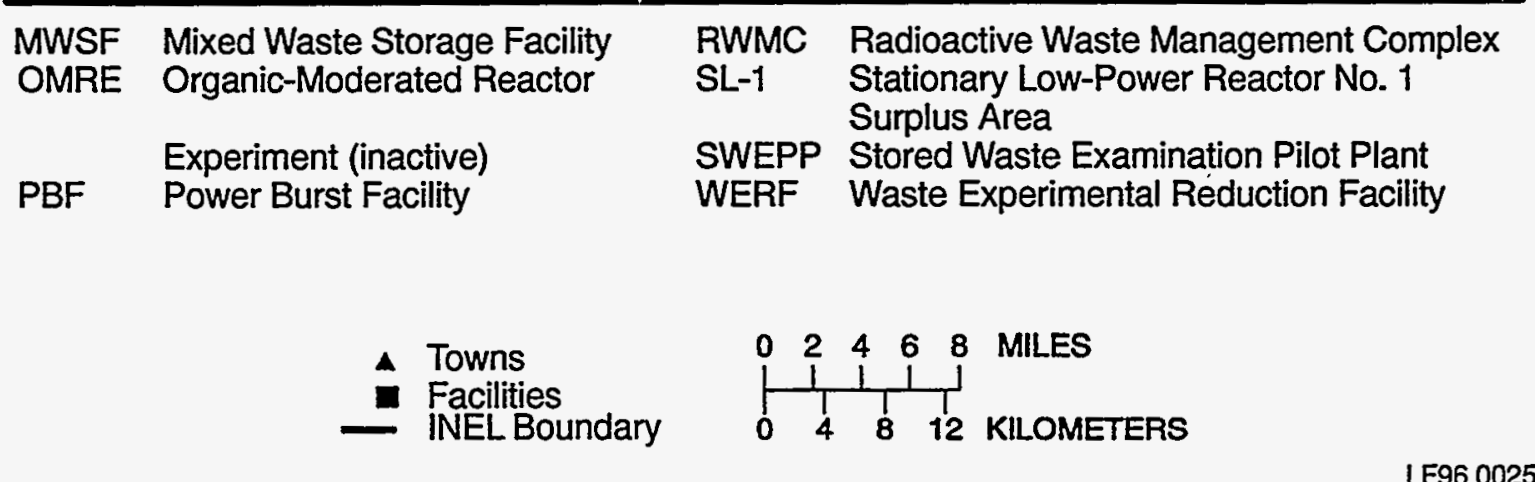

Figure 1. Idaho National Engineering Laboratory location map. 
Biota can affect the integrity of buried contaminated waste by penetrating the soil and allowing water to reach the waste or by transporting radionuclides to the surface. Therefore, RESP routinely collects small mammal and vegetation samples to detect potential biological radionuclide transport. Vegetation sampling is conducted annually at RWMC and WERF. Small mammal sampling and sampling of soil excavated by burrowing animals are conducted only at the RWMC.

Thermoluminescent dosimeters (TLDs) are used to measure cumulative exposures to ambient ionizing radiation at the RWMC and WERF. The TLDs are used to detect changes in ambient exposures attributable to handling, processing, or disposing of radioactive waste. In addition, a surface radiation survey is conducted at the RWMC every six months to monitor all areas within the facility boundary.

The SL-1 surplus area, located near the SL-1 reactor site, contains buried radioactively contaminated building remnants in one pit and two trenches. The OMRE area includes a leach pond and an area formerly occupied by a reactor facility, which was decontaminated and dismantled. The SL-1 and OMRE are nonoperational surplus facilities, and both require less surveillance than the MWSF, RWMC, and WERF. Table 1 summarizes the monitoring activities conducted at the MWSF, OMRE, RWMC, SL-1, and WERF during 1995.

The INEL Project Office of the USGS monitors Eastern Snake River Plain Aquifer groundwater, which is approximately $177 \mathrm{~m}$ (193.6 yd) beneath the RWMC. This monitoring helps determine whether radionuclides and hazardous constituents have migrated from the waste to the groundwater. Water samples are collected quarterly from eight aquifer wells and one perched-water well located in and adjacent to the RWMC Subsurface Disposal Area (SDA). These samples are analyzed for radiological and nonradiological parameters.

\subsubsection{Data Management}

The Environmental Monitoring Information System has been developed for radiological monitoring activities at the INEL. The Environmental Monitoring Information System maintains program-specific databases (i.e., drinking water, effluent, RESP, SESP, etc.), stores and sorts data, provides a method of tracking trends in monitoring data, and helps generate various monitoring reports.

\subsubsection{Quality Assurance}

The Quality Assurance (QA) Program is integrated into all of the measurement programs described in the prior section. The QA Program has been developed to ensure that the sampling methods produce representative samples, to confirm that laboratory analyses are reliable and to verify that the quality of reported results is adequate. Sampling and analysis protocols have been documented in detailed procedures for collecting, analyzing, and reporting sample results. Detailed QA information on the RESP, such as data quality objectives (DQOs) and QA objectives, can be found in the Radiological Environmental Surveillance Program Plan for Waste Management Facilities. ${ }^{8}$ (See Appendix A for QA objectives.)

\subsubsection{Monitoring Activities Review}

Changes in the existing program are made as a result of periodic Monitoring Activities Reviews (MARs). The MAR process involves a technical review by a group of technical experts from the INEL and outside the INEL. The program is reviewed against current regulatory requirements and guidance, recent innovations in methods and equipment, data trends, and data deficiencies. One objective 
considered in the MAR process is the desire to maintain continuity with past designs for trending purposes. Other considerations include logistics, implementing cost, compatibility with ongoing operations, and jurisdictional constraints. Based on the comments of the reviewers, the monitoring program or activity design is revised, or recommended special studies are conducted to further investigate the need for revision.

\subsection{Description of Waste Management Facilities}

\subsubsection{Radioactive Waste Management Complex}

The RWMC occupies 38 hectare (94 acres) of the southwestern part of the INEL (see Figures 2 and 3 ) in the north-central portion of the ESRP. The facility is situated in a small valley surrounded by basaltic ridges rising to $18 \mathrm{~m}$ (19.7 yd) above the landscape. Surface sediments vary in thickness from 0 to $7 \mathrm{~m}(7.7 \mathrm{yd})$ and consist of unconsolidated clay, silt, and gravel. The elevation is $1,527 \mathrm{~m}$ $(1,670 \mathrm{yd})$ above sea level.

DOE uses the RWMC to manage TRU contaminated, solid, and low-level waste generated in national defense and research programs. The facility also supports research and development projects dedicated to shallow land burial technology, waste retrieval and processing technology, and temporary storage of TRU waste destined for a permanent federal repository.

In addition to an administrative area, the RWMC has two operating areas which are the SDA and the Transuranic Storage Area (TSA).

The SDA is a 39 hectare ( 96 acre) area in the western section of the RWMC. It contains an active shallow land burial, subsurface disposal area for the permanent disposal of solid, low-level beta-gamma waste. The area also contains pits and trenches where mixed TRU and LLW were buried between 1952 and 1970. Transuranic waste is contaminated with radionuclides heavier than uranium. Plutonium, for instance, is TRU waste existing in contaminated clothing and equipment. This waste, totalling about $56,634 \mathrm{~m}^{3}\left(74,075 \mathrm{yd}^{3}\right)$ was shipped to the INEL primarily from the Rocky Flats Plant of Golden, Colorado.

Pit 9 is located in the northeast comer of the SDA adjacent to the RWMC. The area is a football field-sized site containing $14,160 \mathrm{~m}^{3}\left(18,519 \mathrm{yd}^{3}\right)$ of radioactive and chemically hazardous waste. Pit 9 was used as a TRU waste disposal site from November 1967 to June 1969. To reduce the risks associated with potential migration of Pit 9 wastes; DOE, Environmental Protection Agency, and the State of Idaho agreed to a Comprehensive Environmental Response, Compensation, and Liability Act interim action. In 1994, Lockheed Environmental Systems and Technologies Company was awarded the contract to clean up Pit 9 . This project is considered to be a technology demonstration. The remediation involves three stages: construction and retrieval, where waste and soil will be physically separated using a remote control system; treatment, where contaminated soils and material will be treated through solvent extraction and chemical leaching; and plasma melter treatment. This project is currently in the construction phase.

Pad A, formerly called the Transuranic Disposal Area, is a prominent waste management area within the SDA. Pad A was originally an asphalt-surfaced area established to store uranium waste, primarily in the form of nitrate salts. The waste contains enriched and depleted uranium. Some waste, which contains TRU elements, was also placed on Pad A from 1972 to 1978. Most of the TRU waste 


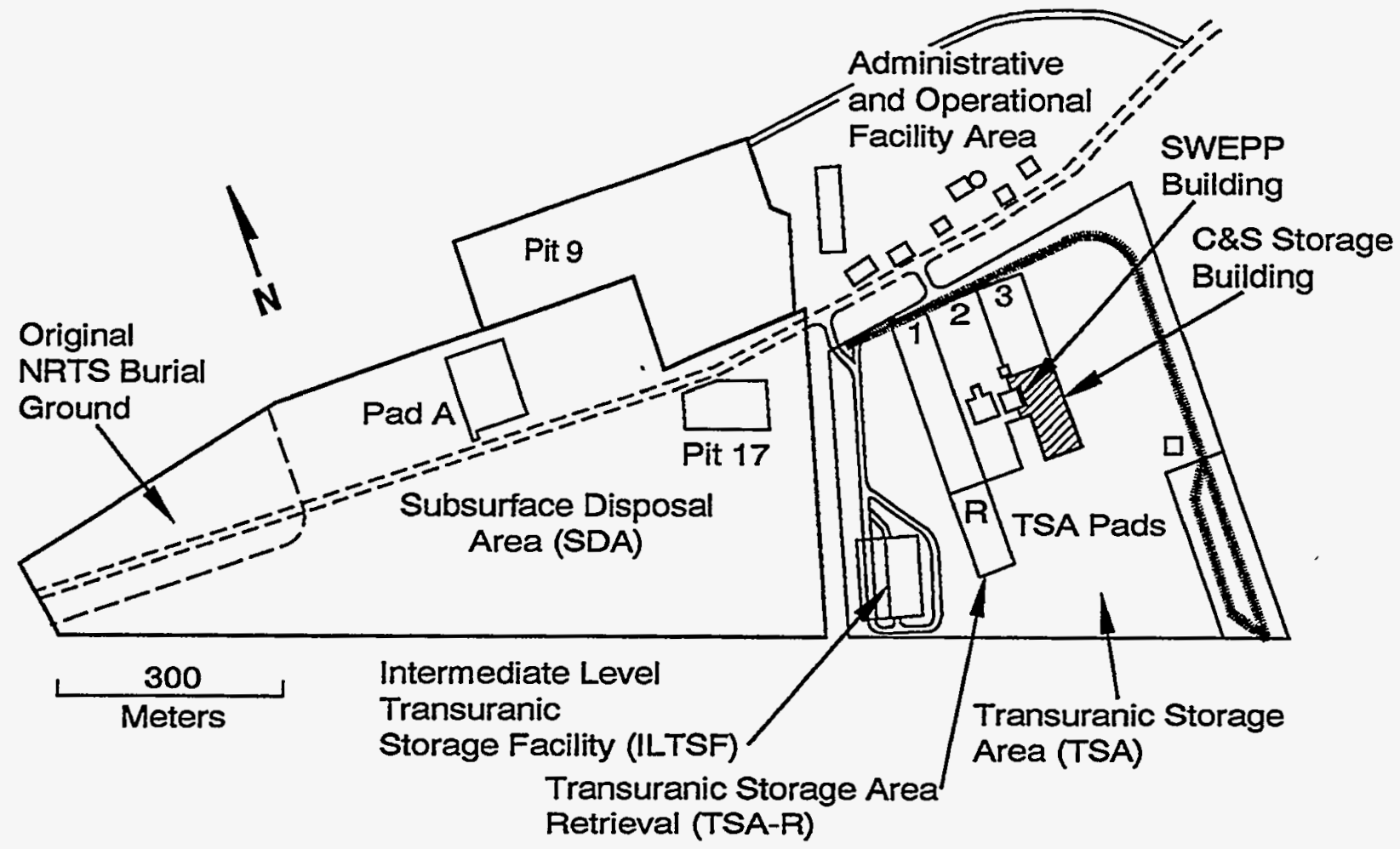

E96 0283

Figure 2. Map of the Radioactive Waste Management Complex.

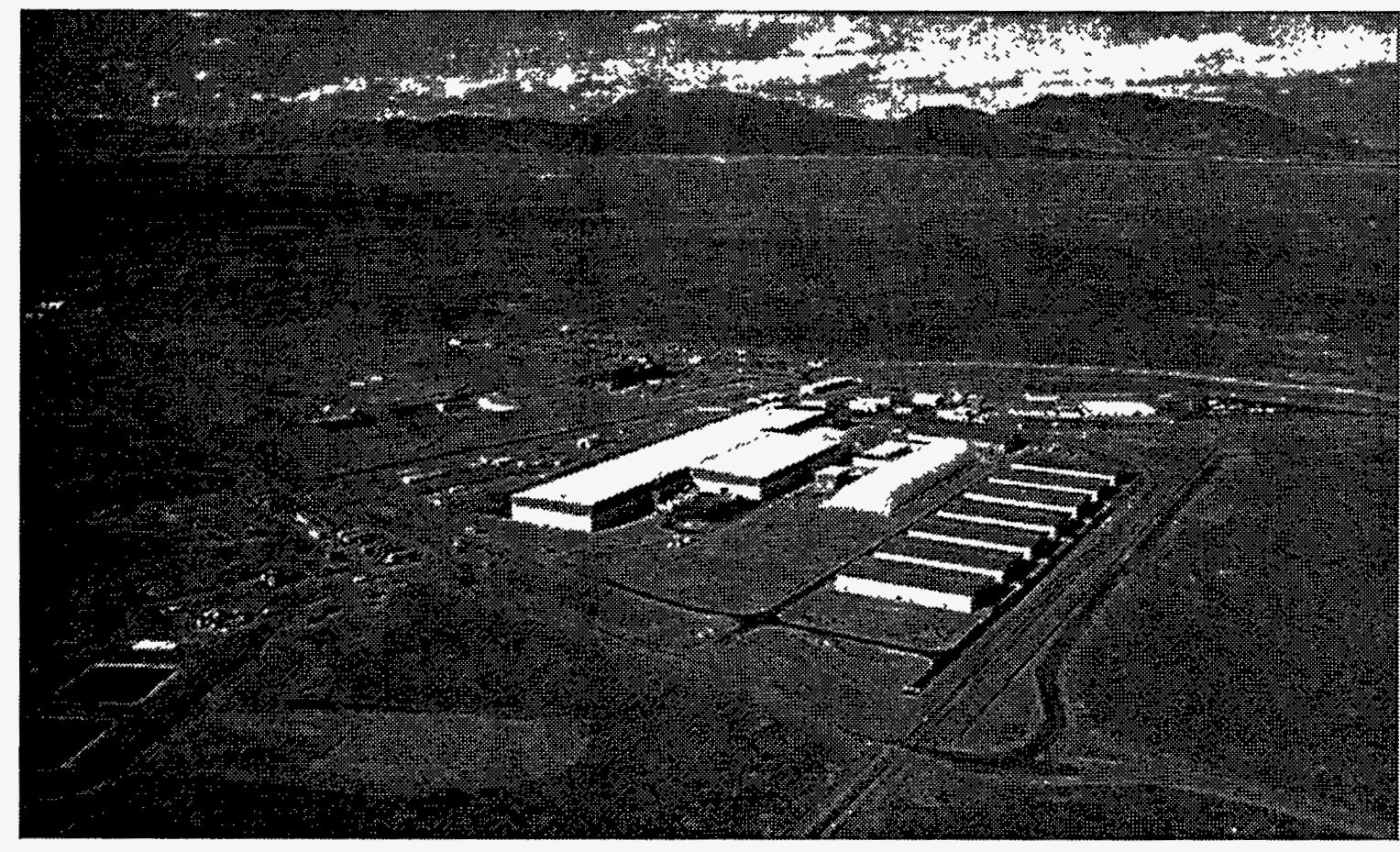

Figure 3. Aerial photograph of the Radioactive Waste Management Complex (photo number 95-942-2-16). 
measures less than $10 \mathrm{nCi} / \mathrm{g}$. However, a number of TRU waste drums are known to measure between 10 and $100 \mathrm{nCi} / \mathrm{g}$, and a very small percentage of drums measure greater than $100 \mathrm{nCi} / \mathrm{g}$. Waste, which contains beryllium, is also stored on Pad A. When the pad was filled with stacked waste drums and boxes, the containers were covered with a 1-m (3 ft) layer of soil. Pad A was closed in November 1978.

The TSA is a 23-hectare (57-acre) area in the southern section of the RWMC dedicated to storage of contact and remote-handled, solid TRU waste. This waste was received at the INEL after 1970 and was placed in retrievable storage. The $65,128 \mathrm{~m}^{3}\left(85,185 \mathrm{yd}^{3}\right)$ of waste is contained in 128,642 drums and 11,468 boxes and is stored in the following facilities:

- TSA-Retrieval Enclosure-Inside the $29,079 \mathrm{~m}^{2}\left(34,778 \mathrm{yd}^{2}\right)$ enclosure, $41,909 \mathrm{~m}^{3}$ $\left(54,815 \mathrm{yd}^{3}\right)$ is stored under layers of soil, wood, and plastic, and another $11,751 \mathrm{~m}^{3}$ $\left(15,370 \mathrm{yd}^{3}\right)$ is stored under plastic.

- Seven Type II Storage Modules-Since December 1994, waste that was previously stored in air support buildings is being moved to these newly permitted storage modules. The Type II modules currently contain over 24,342 containers of waste.

- Two Air Support Buildings-The Certified and Segregated (C\&S) Building and Air Support Building II have provided interim TRU waste storage since 1980 (see Figure 4). The remaining 11,000 containers of waste in the two buildings will be moved to the Type II modules by January 1, 1998.

- Type I Storage Module/Drum Vent Facility-This facility allows drums to be vented to allow aspiration of any existing hydrogen. The Type I Storage Module erected over the existing Drum Vent Facility in 1995 contains a room for collecting the aspirated gases and allows year-around operation.

- The Stored Waste Examination Pilot Plant (SWEPP)-This facility certifies the waste to ensure it meets repository acceptance criteria (see Figure 4). Certified waste will be kept in interim storage in the Type II Storage Modules until the Waste Isolation Pilot Plant (WIPP) in New Mexico opens.

- The TRUPACT Loading Station-This facility is being used to load TRU waste into TRUPACT-II shipping containers for onsite-shipments and will be used to load TRU waste for shipment to WIPP.

\subsubsection{Waste Experimental Reduction Facility}

WERF is located in the south-central portion of the INEL (see Figure 5) about $8 \mathrm{~km}(5.0 \mathrm{mi})$ northeast of the Central Facilities Area (CFA). WERF is located in the decommissioned and modified Special Power Excursion Reactor Test No. 3 (SPERT-III) facility and consists of a concrete block building [Power Excursion Reactor (PER)-609] with high bay and basement operating areas. Incineration and stabilization processes are conducted in this facility. Compacting and sizing activities are performed in a metal building (PER-622), and this building is proposed to house the nonincinerable, mixed LLW treatment activities after upgrades. Transient storage pads for pre- and post-process waste are located adjacent to the facility. 


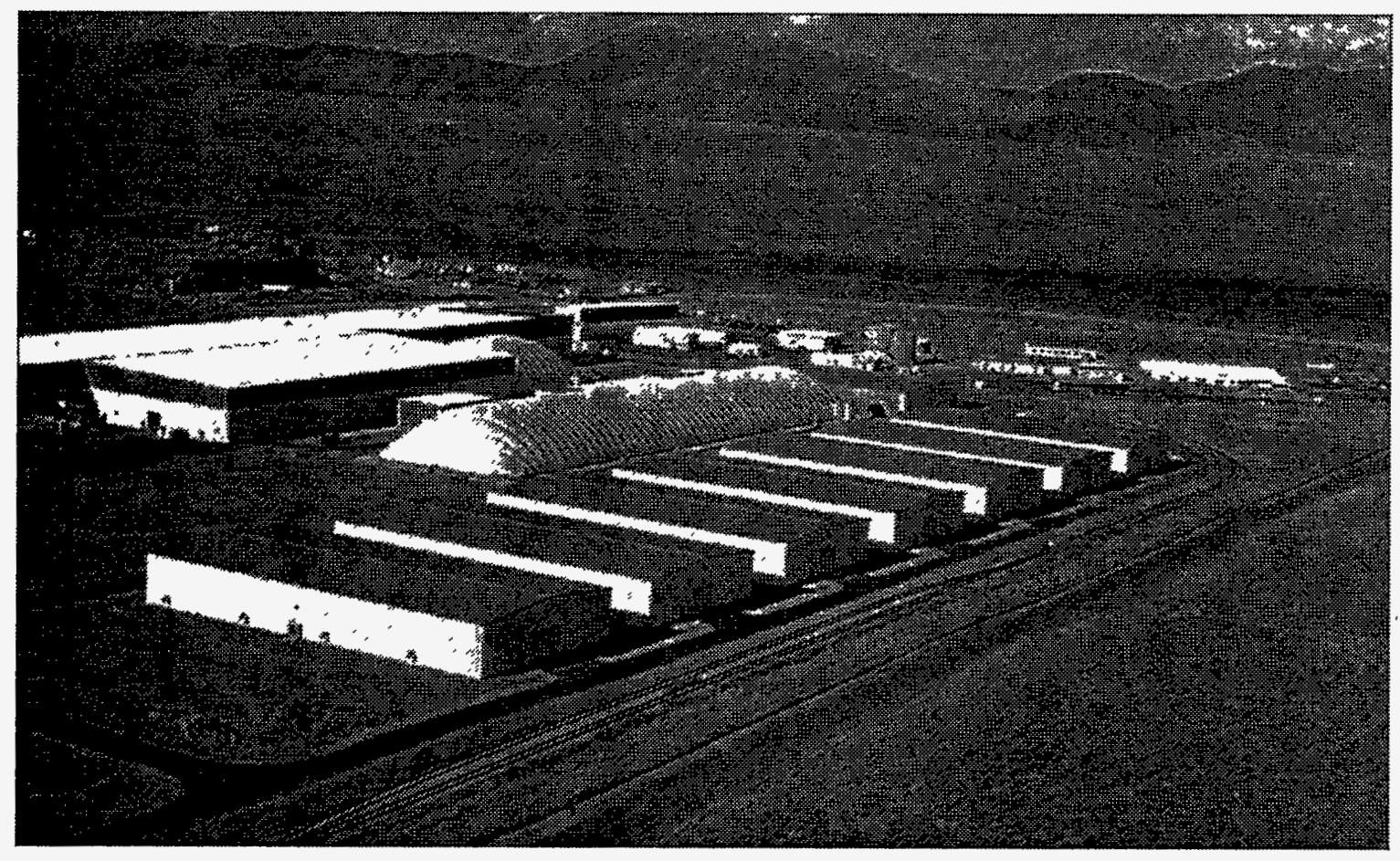

Figure 4. Aerial photograph of the Stored Waste Examination Pilot Plant (photo number 95-942-3-11).

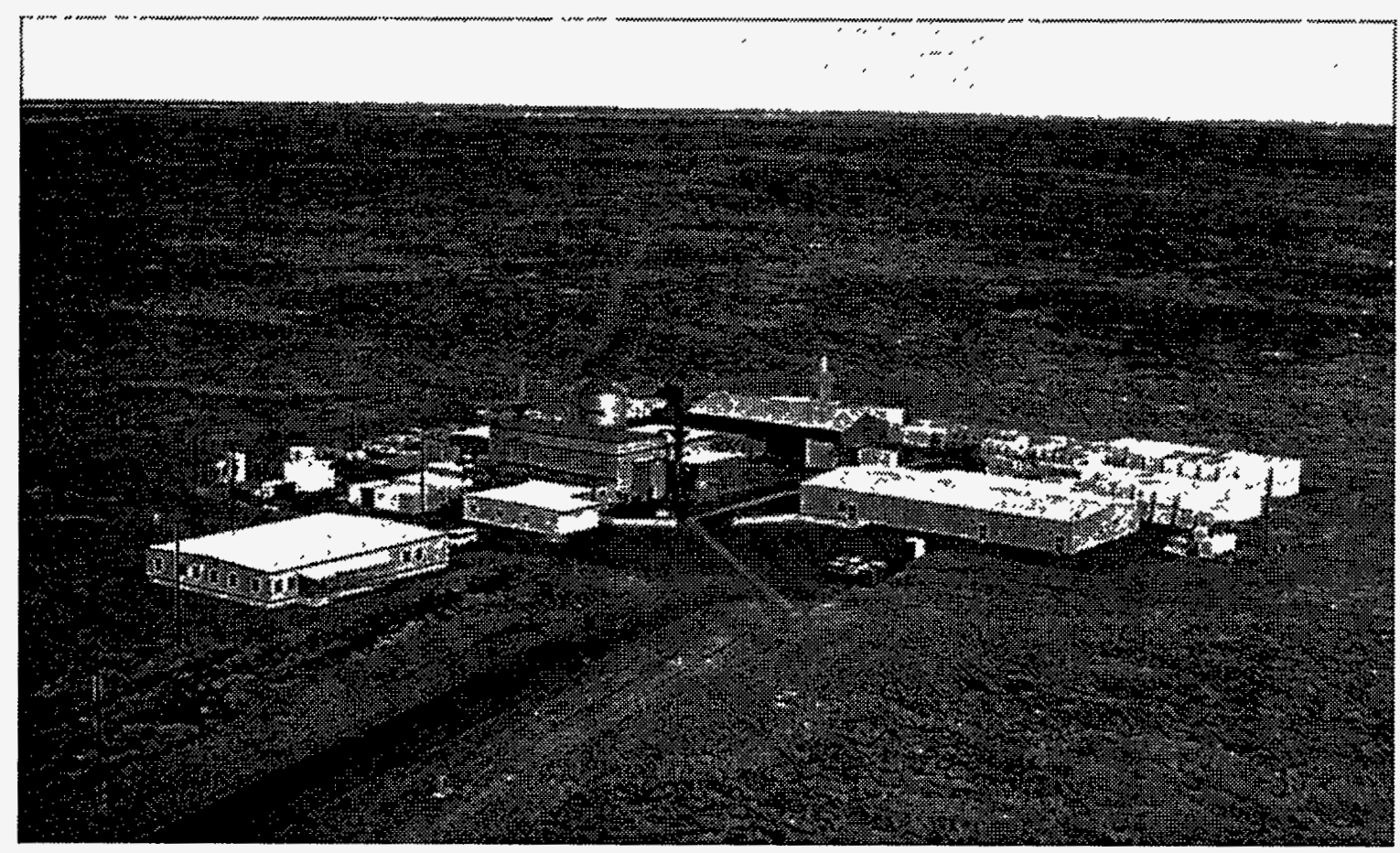

Figure 5. Aerial photograph of the Waste Experimental Reduction Facility (photo number 95-942-3-6). 
Other facilities at WERF include the following:

- $\quad$ PER-623-The WERF Waste Storage Building has been recently constructed for storing mixed waste, hazardous wastes, and contaminated lead.

- $\quad$ PER-635-This building originally housed the size reduction operations and is currently used for equipment storage.

- PER-641-The WERF Operations Support Building was recently constructed to house support personnel.

WERF was established in 1982 to demonstrate that commercially available volume reduction techniques could be used to significantly reduce the volume associated with LLW disposal. Specifically, WERF provides treatment by volume reduction of solid LLW through compaction, incineration, and sizing operations. WERF also provides treatment of liquid LLW, hazardous wastes, and mixed LLW through incineration and stabilization. Exhaust gases from WERF activities are filtered through baghouse and high-efficiency particulate air filters prior to discharge.

\subsubsection{Mixed Waste Storage Facility}

The MWSF is the temporary storage facility for mixed waste at the INEL, and is housed in the decontaminated and dismantled SPERT-IV reactor building (PBF-613). The building, which was constructed in 1960, consists of a high bay and two low-bay wings. The high bay is a $22 \times 15 \times 14-\mathrm{m}$ $(24 \times 16 \times 15 \mathrm{yd})$ steel-girded, reinforced concrete, cinder block structure with a deep basement, and a metal roof. The total capacity of the MWSF, including the Portable Storage Units, is $365,252 \mathrm{~L}$ ( $96,500 \mathrm{gal})$. Cargo containers in the parking area adjacent to the MWSF are used for storing mixed waste solids only, including lead. No flammable liquids or reactive wastes are stored in the cargo containers.

\subsubsection{Stationary Low-Power No. 1 Surplus Area}

The SL-1 Surplus Area is located in the south-central portion of the INEL, about $7.2 \mathrm{~km}$ (4.5 mi) north of the southern INEL boundary. The total area within the SL-1 Surplus Area exclusion fence is about $1 \mathrm{~km}^{2}\left(0.4 \mathrm{mi}^{2}\right)$. No surface facilities have been constructed within the fence. The area contains most of the SL-1 dismantled reactor building, radiologically contaminated equipment, about $750 \mathrm{~m}^{3}$ $\left(981 \mathrm{yd}^{3}\right)$ of radiologically contaminated dirt and gravel, and waste for decontamination in one trench and two pits.

\subsubsection{Organic-Moderated Reactor Experiment}

The OMRE area is located in the south-central portion of the INEL, about $7.6 \mathrm{~km}$ ( $4.7 \mathrm{mi})$ north of the southern INEL boundary, and occupies about $0.7 \mathrm{~km}^{2}\left(0.3 \mathrm{mi}^{2}\right)$. The OMRE project was completed in 1963, and the facility was decontaminated and dismantled in 1979. The building and underground reactor were disassembled; the radiologically contaminated material was disposed at the RWMC, and the uncontaminated parts were sold as scrap. The leach pond was backfilled with soil, and the entire area was revegetated with a mixture of native grasses in 1981. No waste was buried within the OMRE boundaries, and no surface facilities remain there today. 


\section{MONITORING METHODS AND RESULTS}

Section 2 discusses the monitoring methods and results for calendar year 1995 with the major portion addressing radiological monitoring of INEL Waste Management Facilities. Radiological surveillance includes the following topics: (a) airborne particulates, (b) RWMC surface runoff, (c) soils, (d) biota (vegetation and small mammals), (e) penetrating radiation, and ( $f$ ) surface radiation. Table 1 shows the RESP activities performed at these Waste Management Facilities. In addition, Section 2.8 briefly discusses groundwater monitoring at the RWMC by the USGS.

Appendices that discuss Quality Assurance, Appendix A; Detection Limits, Appendix B; Statistical Analysis Methods, Appendix C; and Environmental Standards, Appendix D, are also included. Detailed information on radiological analyses of all sample media is discussed in Appendix B.

\subsection{Overview}

Results from the analysis of samples collected at the RWMC showed an overall increase in the number of positive measurements of Sr-90 and transuranic radionuclides in most media collected from April through September (second and third quarters). No unusual trends were noted in air and water collected during the first and fourth quarters. Vegetation and soils are not collected during those quarters. These concentrations were all below action levels and most concentrations were at or near detection limits. Although only low levels of activity were measured in the samples, the increase in the number of positive measurements is reason for further investigation. During FY 1996, additional samples will be collected from selected media in an effort to further define possible causes. After review of the operational activities at the RWMC, the following activities were identified as candidates for generating resuspension of previously contaminated soils; thereby, increasing the number of positive detections: construction of the TSA Retrieval Building and associated movement of soils and construction of Pit 9 and its associated activities in the northeast corner of the SDA. Media collected at the other monitored facilities showed no unusual trends. The following media sections present the maximum-concentrations and compare them to historical concentrations and alert levels.

\subsection{Ambient Air Monitoring}

In addition to the general RESP objectives, the specific objectives of ambient air sampling are as follows: (a) determine concentrations of airborne radionuclides in the vicinity of INEL Waste Management Facilities, (b) report comparisons of measured concentrations to reference levels based on Derived Concentration Guides (DCGs) for the public given in DOE Order 5400.5, and (c) detect and report significant trends in measured concentrations of airborne radionuclides.

Air is a critical pathway of contaminant migration through the environment at the INEL. 10 Fugitive dusts from the RWMC may contain small amounts of sorbed, man-made radionuclides in addition to naturally occurring radionuclides. The general approach to monitoring an area source, such as the fugitive dusts at the RWMC, is to monitor the facility perimeter.

\subsubsection{Air Monitoring Program Designs and Methods}

The 1983 MAR (EGG 1983a) provides much of the rationale for the current ambient air monitoring design. ${ }^{10}$ As recommended by the MAR, the number of high-volume air monitor locations around the SDA was reduced to seven. A replicate monitor and a control location were also added to the air monitoring system. In addition, high-volume air monitors were replaced in 1986 with 
suspended particulate (SP) air monitors that operate at $0.14 \mathrm{~m}^{3} / \mathrm{min}$ (see Figure 6). Particulate material is collected on a membrane filter (Gelman Model Versapor-1200, $1.2 \mu \mathrm{m}, 102$-mm diameter).

During July 1992, most of the existing SP air monitors were replaced with intermediate-flow $\left(0.11 \mathrm{~m}^{3} / \mathrm{min}\right)$ particulate matter $\leq 10 \mu \mathrm{m}\left(\mathrm{PM}_{10}\right)$ air monitors (see Figures 7 and 8$)$. The $\mathrm{PM}_{10}$ air monitors use the same membrane filter as the SP air monitors, and sample particulates less than $10 \mu \mathrm{m}$ in size, which is considered to be the respirable fraction. The $\mathrm{PM}_{10}$ fraction is also the range of particle sizes that can be transported to offsite locations by wind. Measuring the respirable fraction provides data which meets the general RESP objective for providing data which may be used for dose calculations.

SP air monitor locations remain at RWMC and WERF, where additional coverage helps characterize conditions in the immediate vicinity. SP monitors are placed at locations 2.0, 20.0, and 26.0 of RWMC and location 300 at WERF (see Figures 9 and 10, respectively).

Replicate $\mathrm{PM}_{10}$ samples are collected at location 4.3 at the RWMC as part of the RESP Quality Assurance/Quality Control Program (see Figure 9). Control sample locations 15 and 15.3 for the RWMC are at the Experimental Breeder Reactor No. I (EBR-I) area, approximately $3 \mathrm{~km}$ (1.9 mi) east-northeast of the RWMC. The WERF control sample, location 603.3, serves both MWSF and

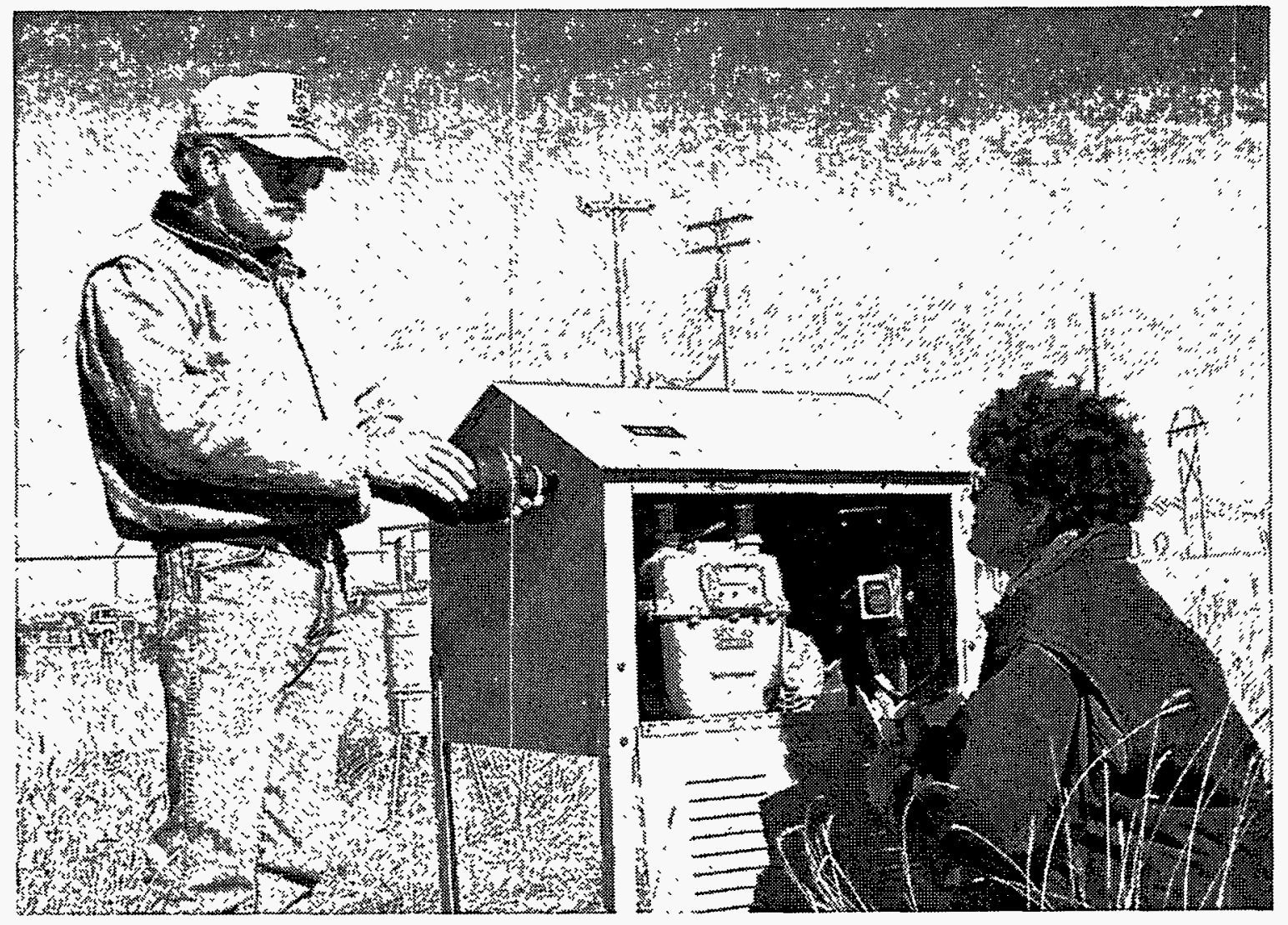

Figure 6. Collecting a particulate air filter from an SP air monitor (photo number DP960014). 


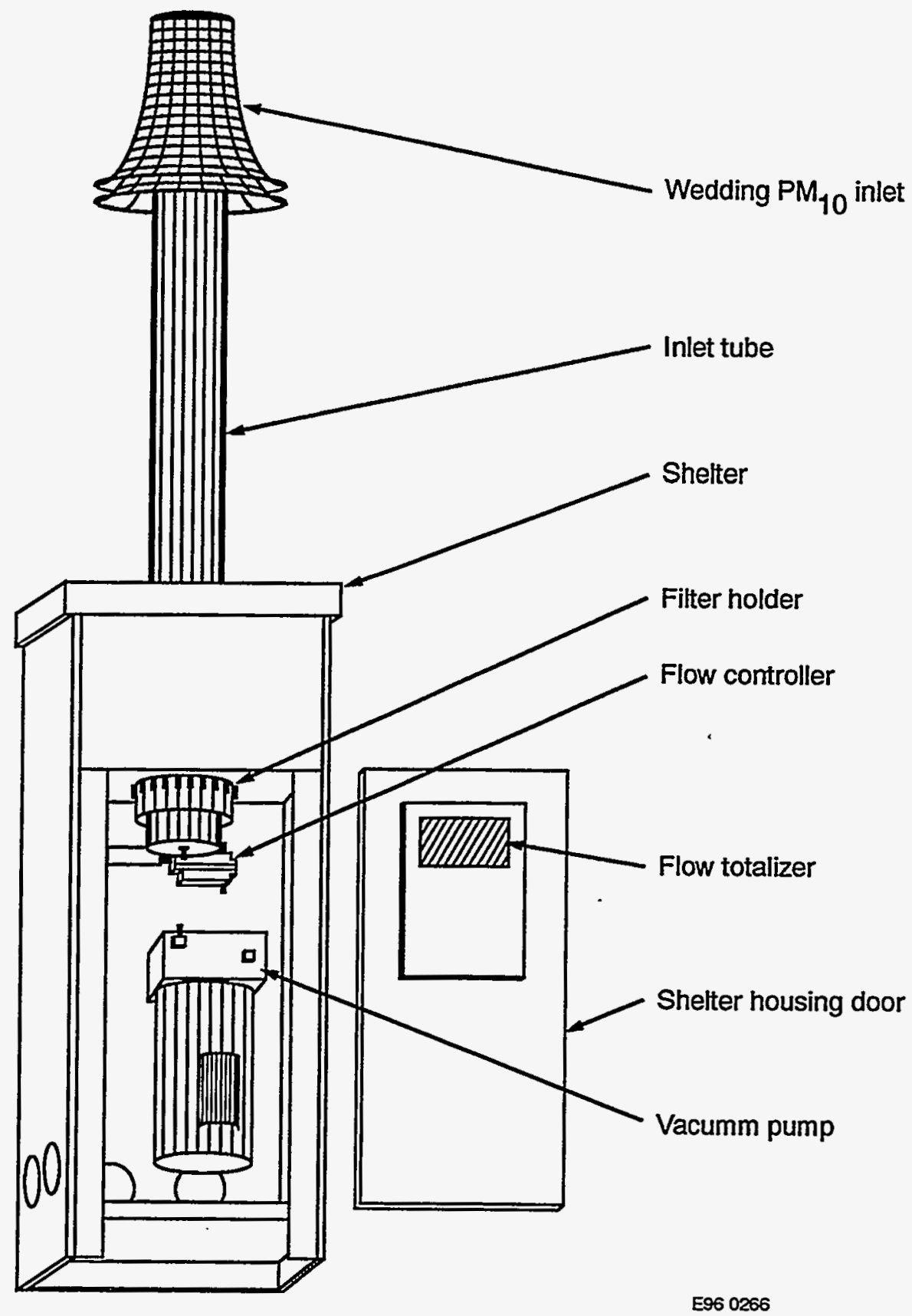

Figure 7. $\mathrm{PM}_{10}$ air monitor. 


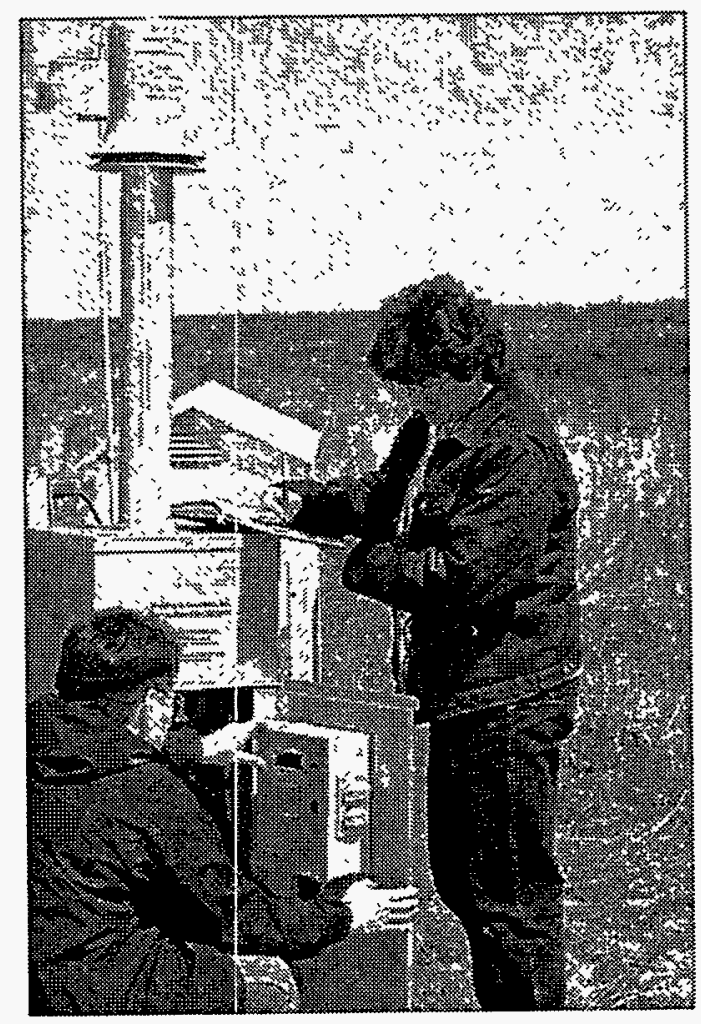

Figure 8. Collecting a particulate air filter from a $\mathrm{PM}_{10}$ air monitor (photo number 95-309-1-1).

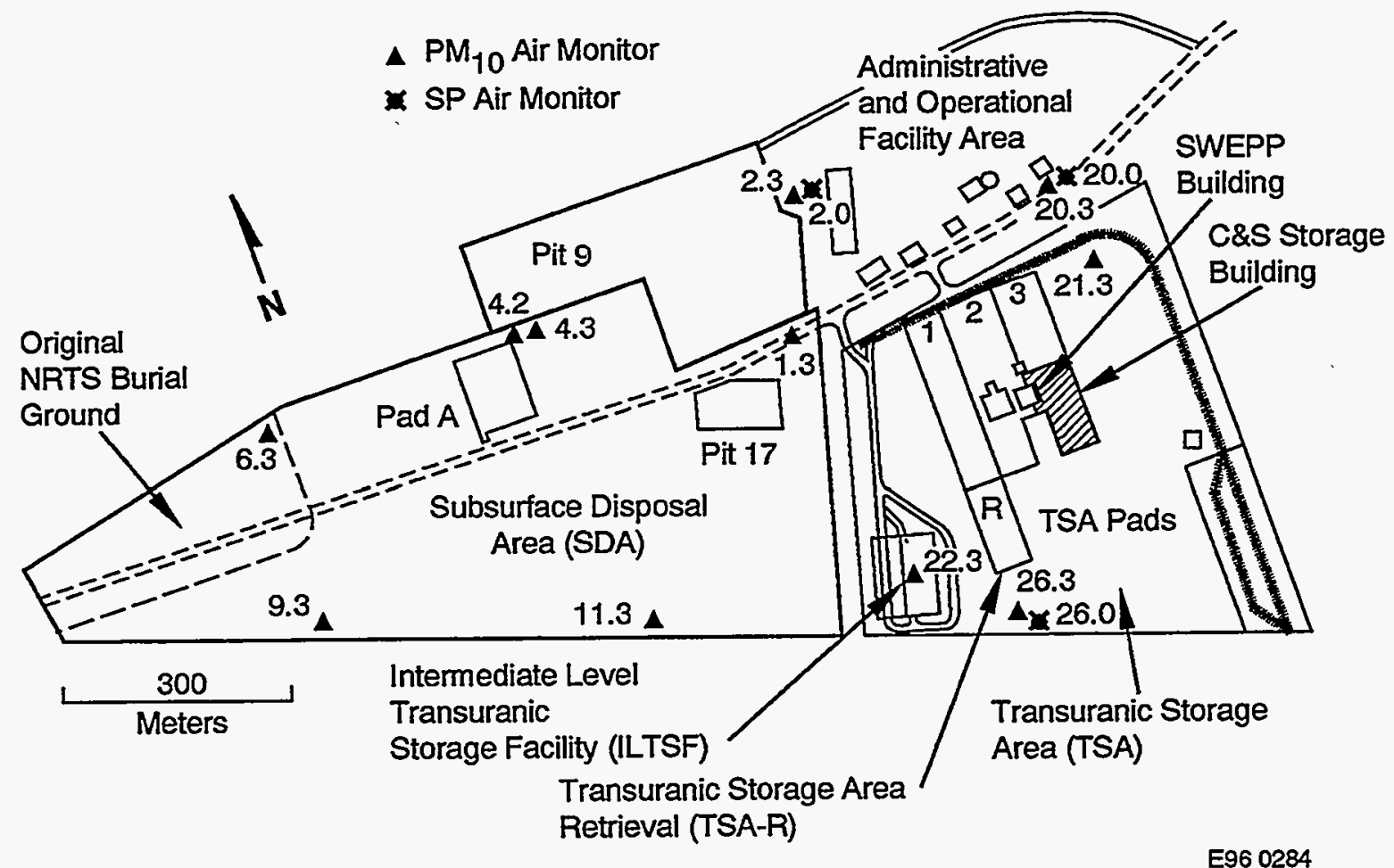

Figure 9. RWMC SP and $\mathrm{PM}_{10}$ air monitoring locations. 


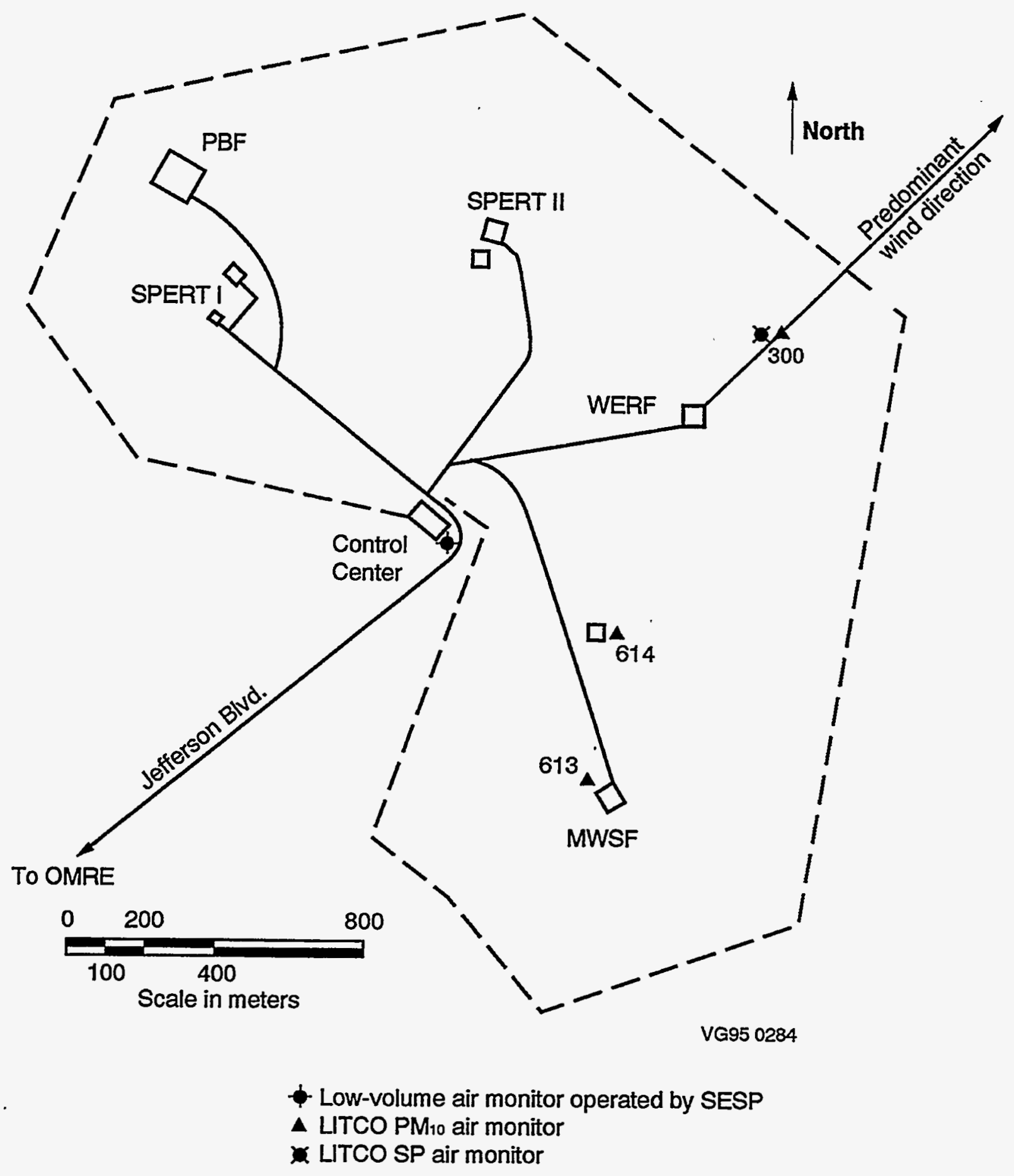

Figure 10. WERF air monitoring locations. 
WERF, and is located next to the INEL Main Gate, Building 603 (see Figure 11). Prevailing wind patterns as well as availability and accessibility of electrical power influenced the selection of monitor locations.

Air filters are collected and analyzed semimonthly for gross-alpha and gross-beta activity, and monthly composites of each location are analyzed quantitatively for gamma-emitting radionuclides. Filters from the RWMC are also composited quarterly by location, and are analyzed for specific alphaand beta-emitting radionuclides. The approach used for data analysis is presented in Appendix C. RESP results are compared to data supplied by SESP for air monitors which are located onsite and offsite.

Gross-alpha analysis provides rapid detection of significant changes in airborne alpha activity at the RWMC. The gross-alpha results are also used as a criteria to screen samples for immediate radiochemical analyses for specific alpha emitters. Results of gross-beta analysis of the air filters are evaluated to determine if there are any significant increases in the sample radioactivity that may require more immediate or more in-depth analysis by gamma spectrometry or radiochemistry. Gross-beta analysis is thus used as a quick and inexpensive screening tool. Both gross-alpha and beta measurements are used to characterize trends in concentrations of radioactivity in the environment.

Gross-beta results are evaluated semimonthly by comparing these results with historical and background data for indicating trends using a log concentration-versus-time plot. RESP compares each plot against control concentrations, detection limits, and alert levels. Alert levels are $25 \%$ of the most restrictive DCGs for the public. Comparisons are made between stations and control monitors, using statistical analysis methods (see Appendix C). The RESP also compares gross-beta activity to the

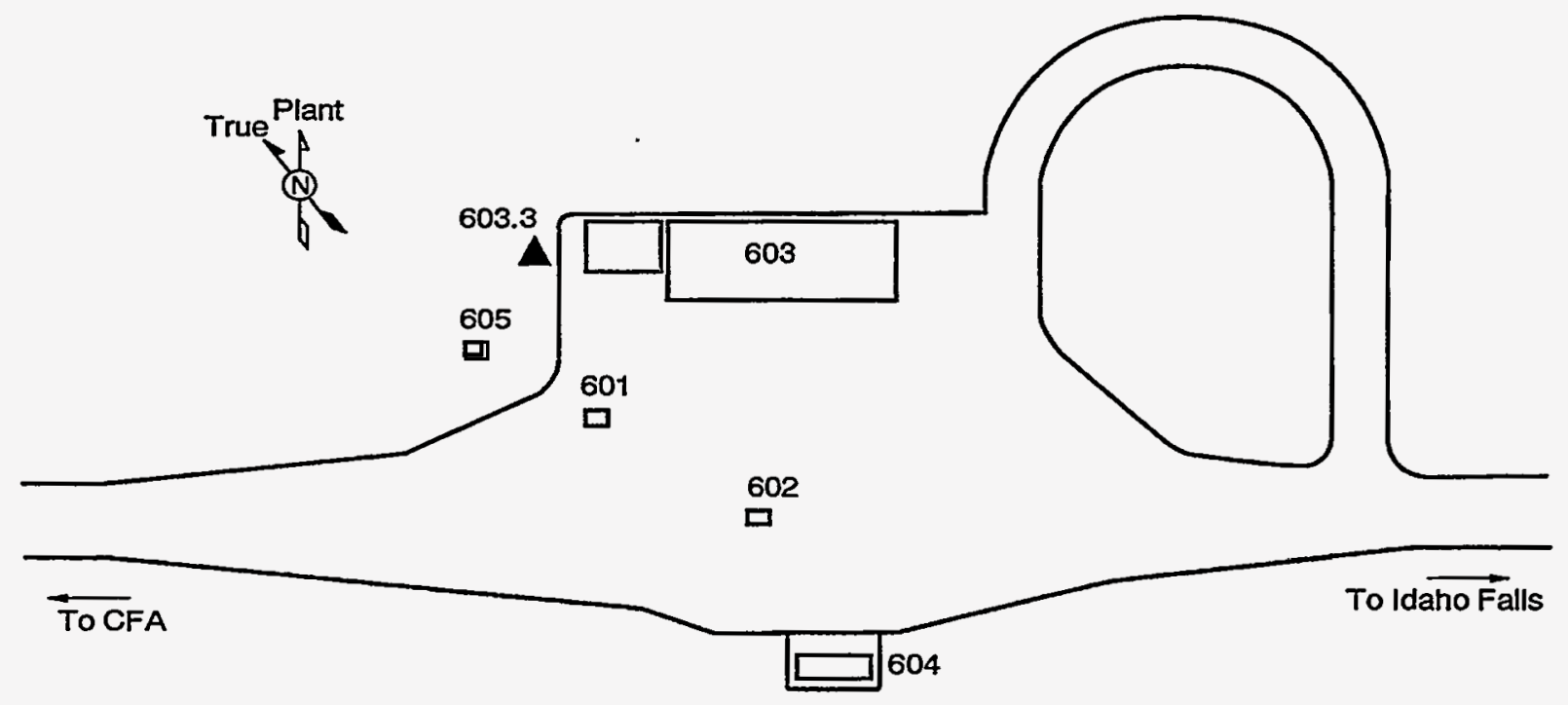

E960281

$\mathrm{PM}_{10}$ air sampler location

Figure 11. WERF air monitoring control location at the Main Guard Gate. 
DCGs for Sr-90, which is the most restrictive DCG for waste-related, beta-emitting radionuclides to be detected at the RWMC (see Appendix D). Pu-241 is a low-energy, beta emitter and has a more restrictive DCG than Sr-90; however, it is generally detected through its alpha- and gamma-emitting daughter, Am-241.

\subsubsection{Trend Analysis}

The RESP PM $\mathrm{PM}_{10}$ monitors are designed to only admit particles less than 10 microns in diameter while the SPs admit larger particles. Concentrations measured by these samplers are not directly comparable. The particle size restriction of the $\mathrm{PM}_{10}$ monitors are appropriate for pathway modeling, since larger particles are not readily transported by wind and do not present an inhalation risk.

To indicate general trends in values over time, data in the graphs were smoothed using polynomial smoothing. Either second- or third-order polynomials were fit to all data sets. In all instances, concentration trends were generally lowest during mid-year with higher values reported during the fall and winter months. These trends are similar in shape to those noted for 1994, where concentrations were generally lowest during mid-year. This trend results from seasonal changes and is consistent with results seen in previous years.

Graphs of gross-alpha and gross-beta concentrations over time from all locations (except for the RWMC and WERF control locations) are given in Figures 12-17.

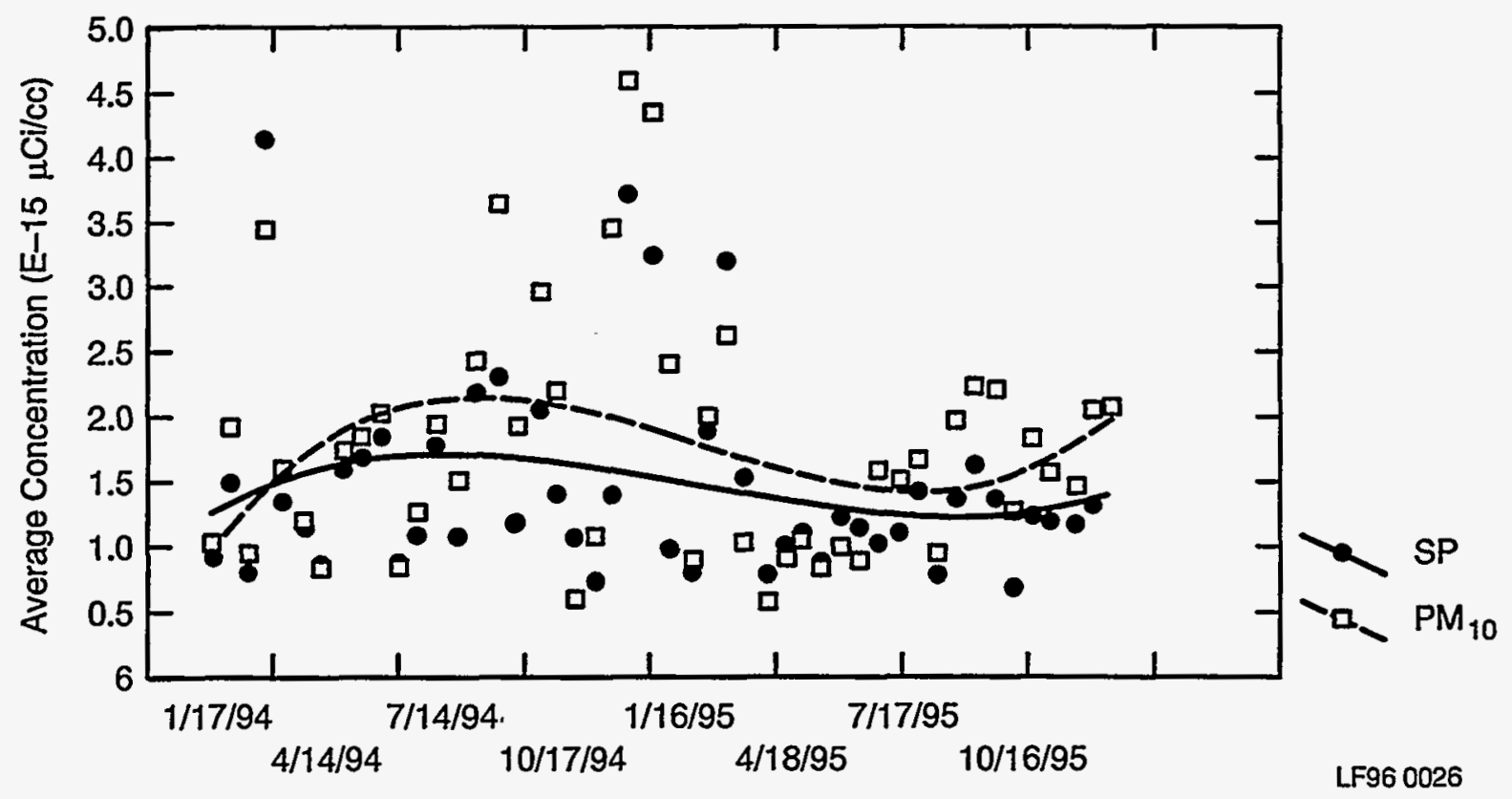

Figure 12. Gross-alpha concentrations by monitor type for Locations $2.0,20.0,26.0$, and 300 using third-order polynomial smoothing. 


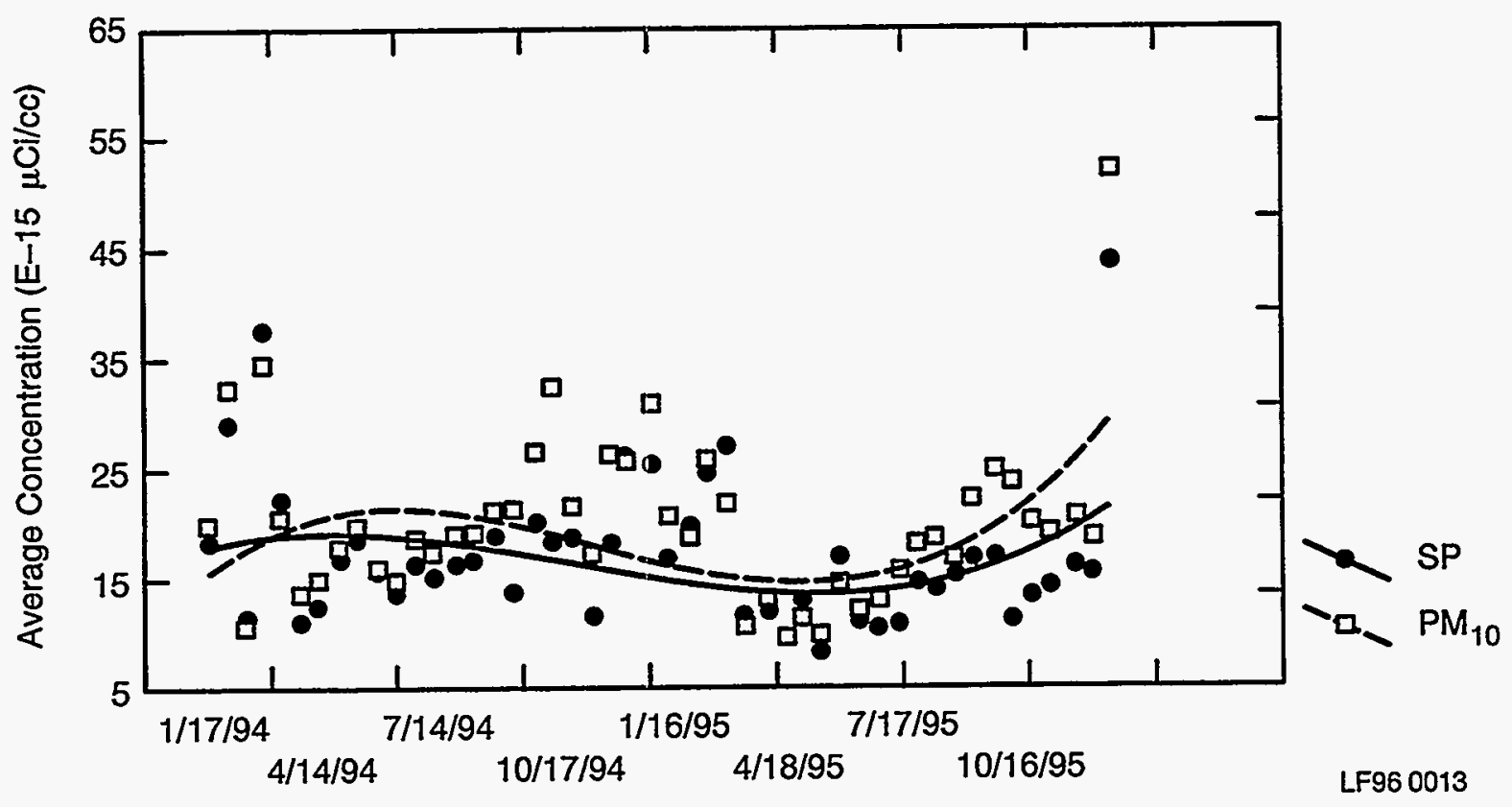

Figure 13. Gross-beta concentrations by monitor type for Locations $2.0,20.0,26.0$, and 300 using third-order polynomial smoothing.

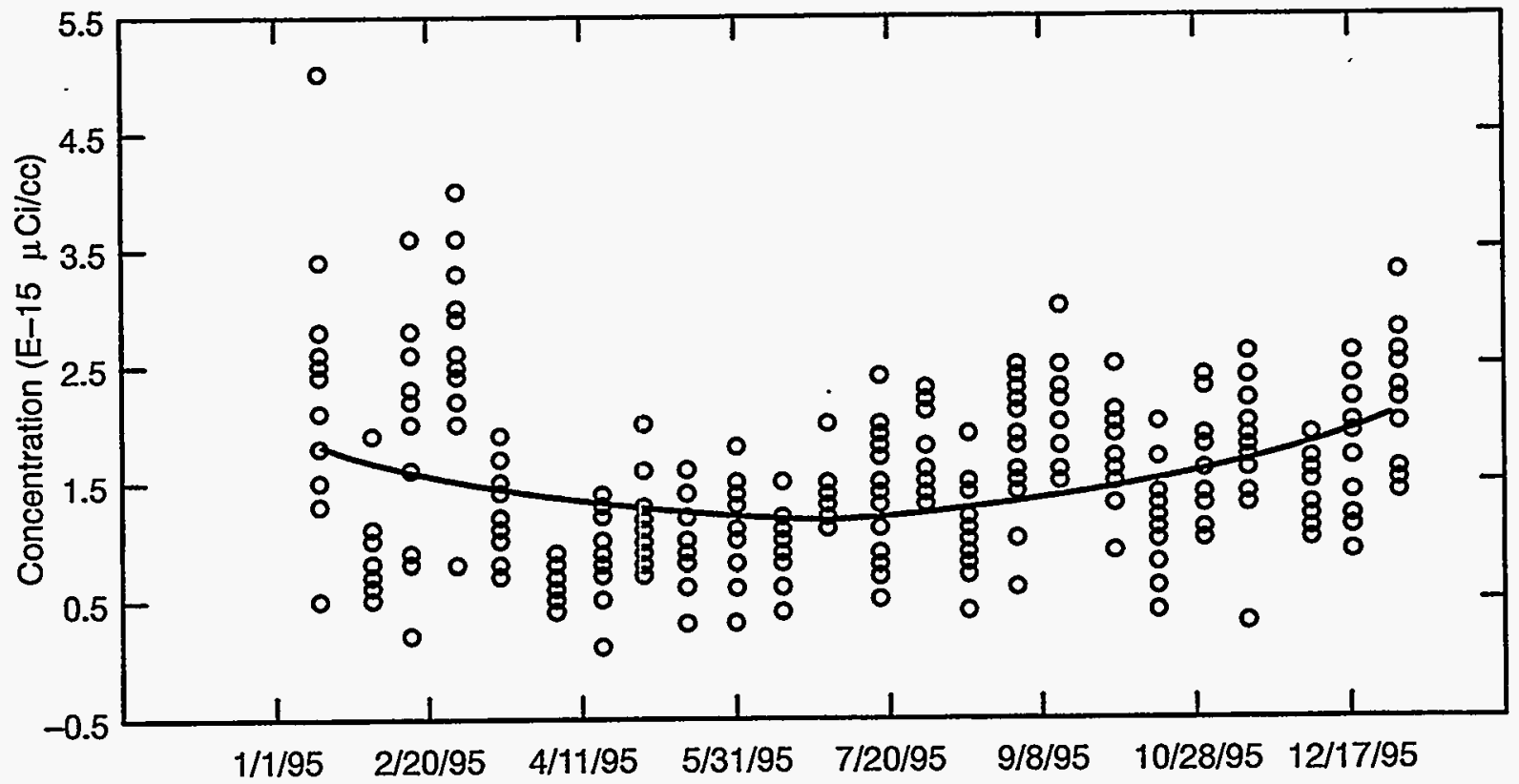

LF96 0008

Figure 14. Gross-alpha concentrations for $\mathrm{PM}_{10}$ air monitors using second-order polynomial smoothing. 


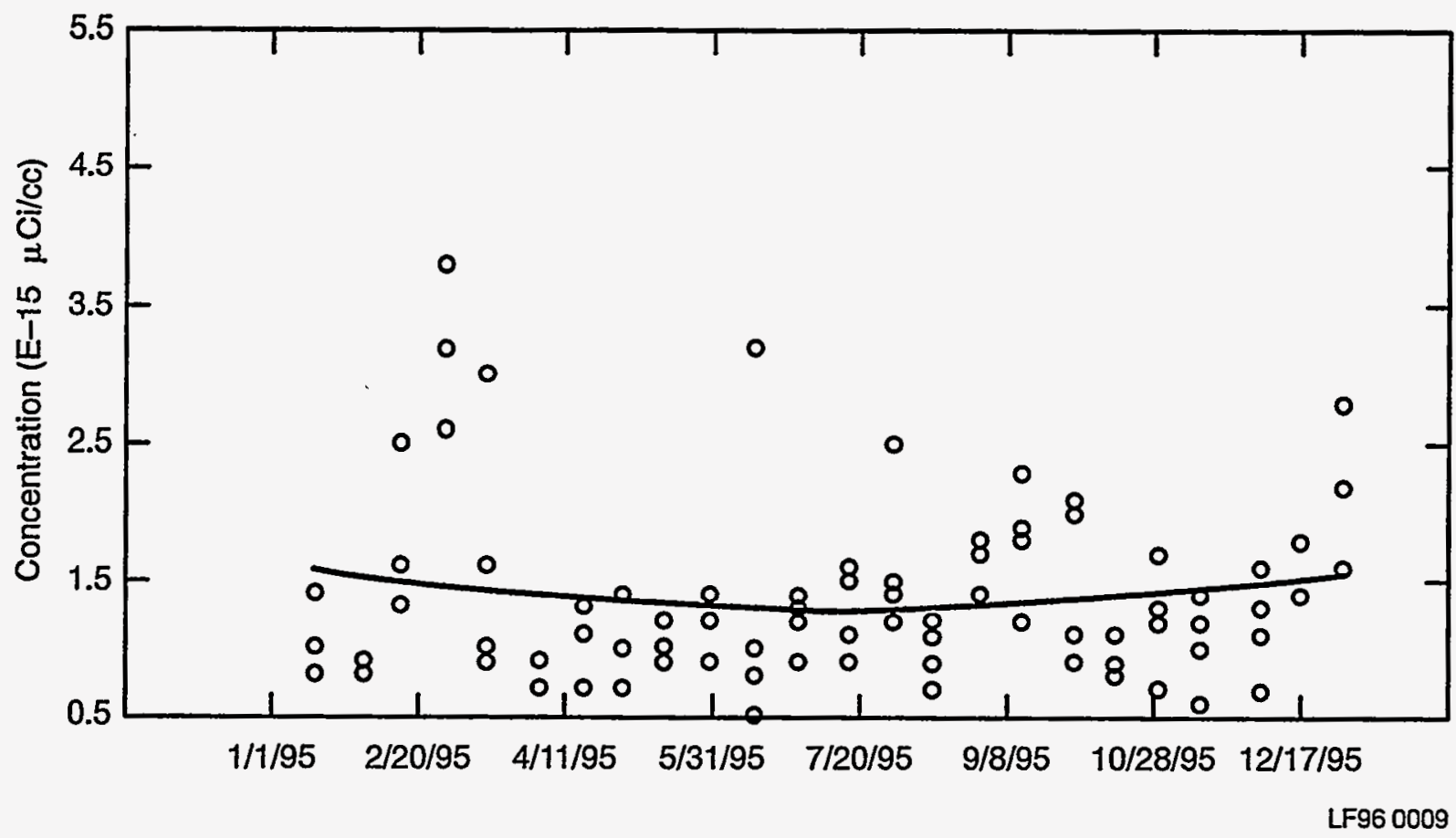

Figure 15. Gross-alpha concentrations for SP air monitors using second-order polynomial smoothing.

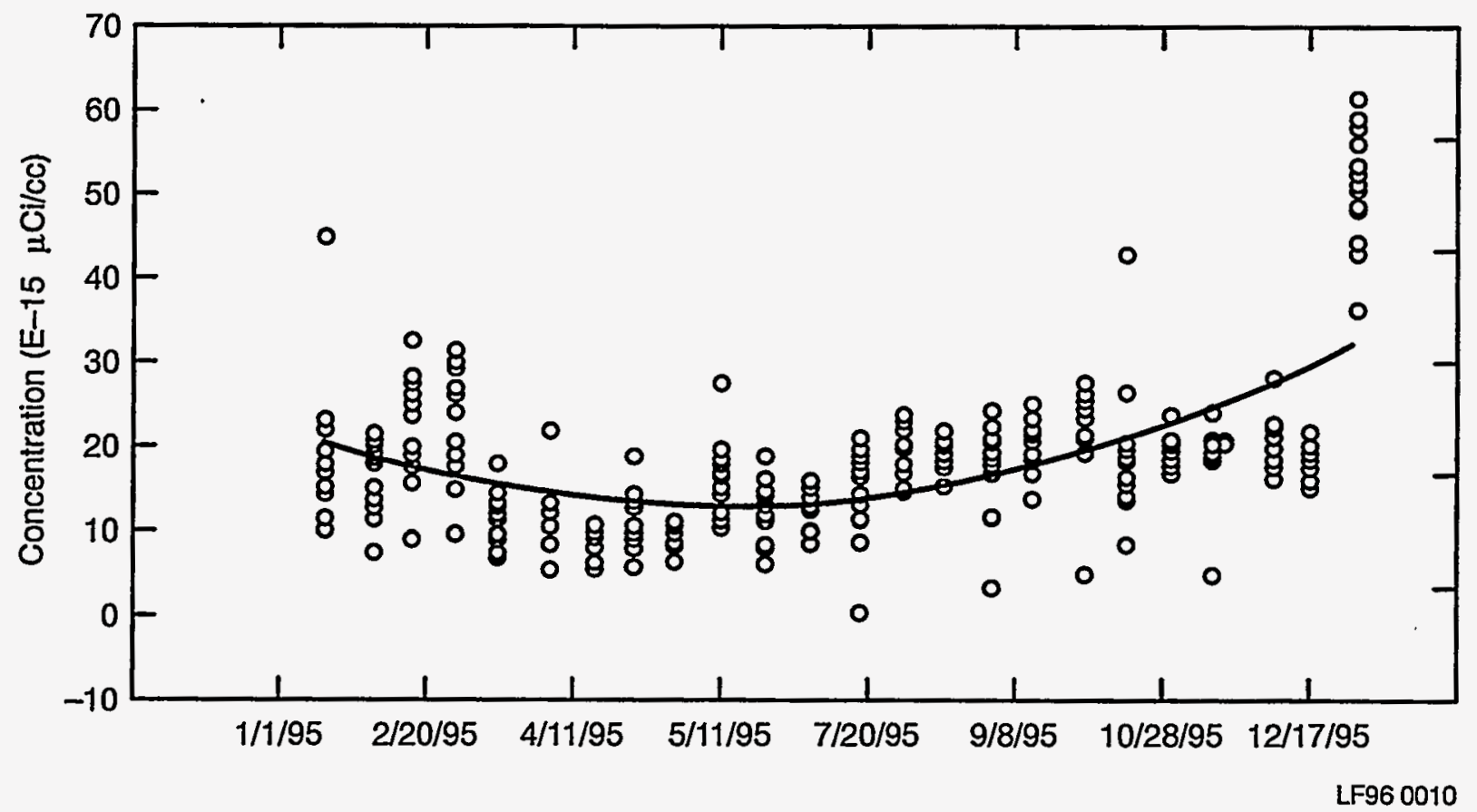

Figure 16. Gross-beta concentrations for $\mathrm{PM}_{10}$ air monitors using second-order polynomial smoothing. 


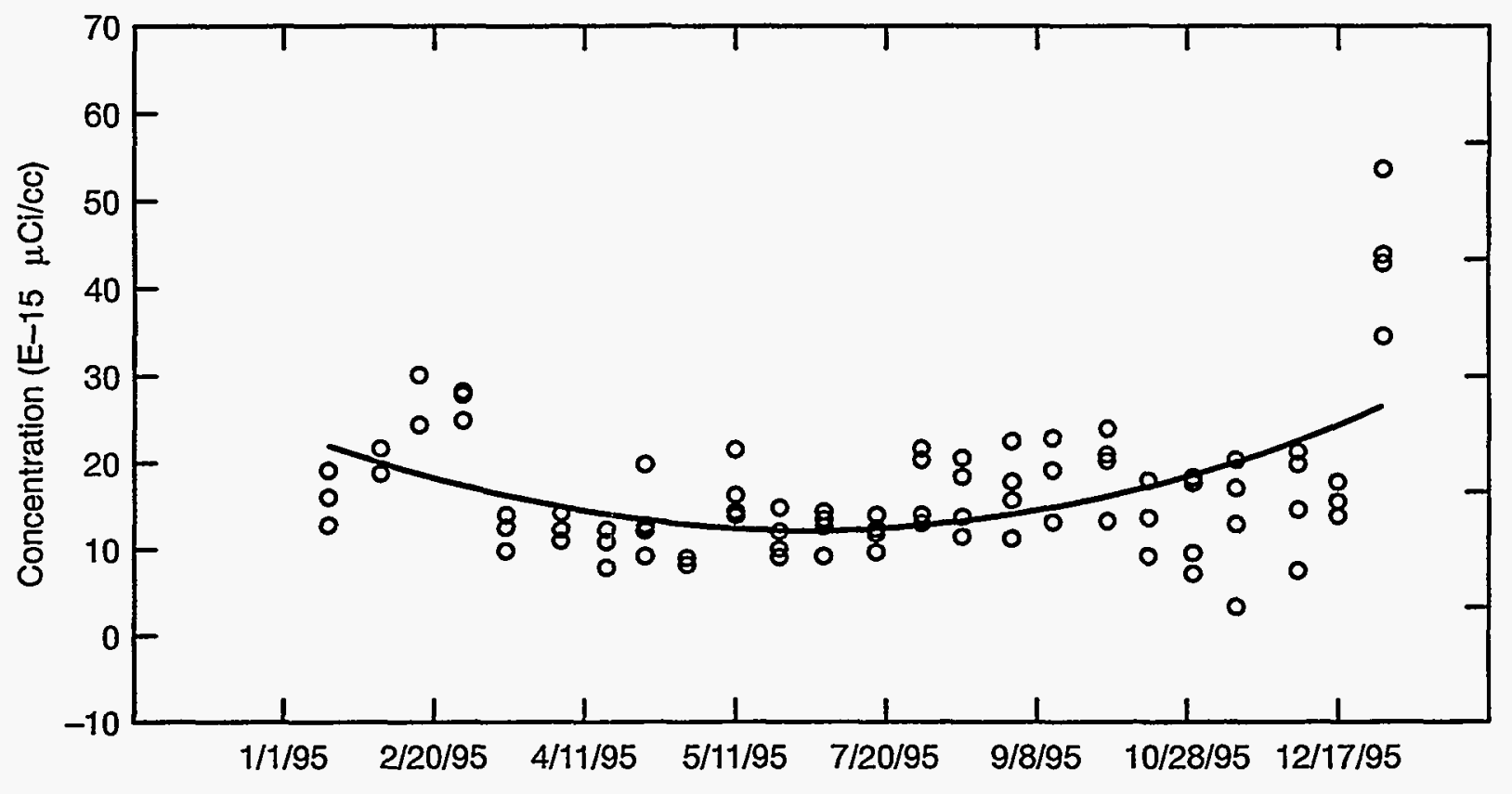

LF96 0011

Figure 17. Gross-beta concentrations for SP air monitors using second-order polynomial smoothing.

\subsubsection{Comparisons by Facility}

A set of box and whisker plots are presented which compare gross-alpha and gross-beta concentrations for each monitor type by facility. Summarized 1994 and 1995 data are presented in Figures 18-21 to provide an indication of short-term changes in levels. Figures 18 and 19 do not include points considered outliers, while Figures 20 and 21 include all points reported for 1994 and 1995. Outlier and non-outlier box and whisker plots are included due to the high values reported for September 1, 1994, at the SDA.

Corresponding summary statistics (e.g., means, medians, maximum, and minimum values) with all 1994 and 1995 data included are given in Tables 2 and 3. Negative concentrations reported by the laboratory were included. These concentrations reflect statistical fluctuations in measuring low-level samples.

As with the 1994 analysis of gross-alpha values, very little variability was seen among facilities during 1995 (see Figures 18 and 20). For the SP monitors, a slight increase in median value from 1994 to 1995 was seen at the SDA; all other locations reported slight decreases. All five locations with $\mathrm{PM}_{10}$ monitors indicated slight decreases in median values from 1994 to 1995 . To test for statistical significance of the variations in medians from 1994 and 1995, the Kruskal-Wallis significance tests was performed for each facility. The changes in median values from 1994 to 1995 for the $\mathrm{PM}_{10}$ monitors located at the SDA and WERF and the SP monitors located at the SWEPP and the SWEPP control location were found to be statistically significant at the .05 level. None of the median changes 


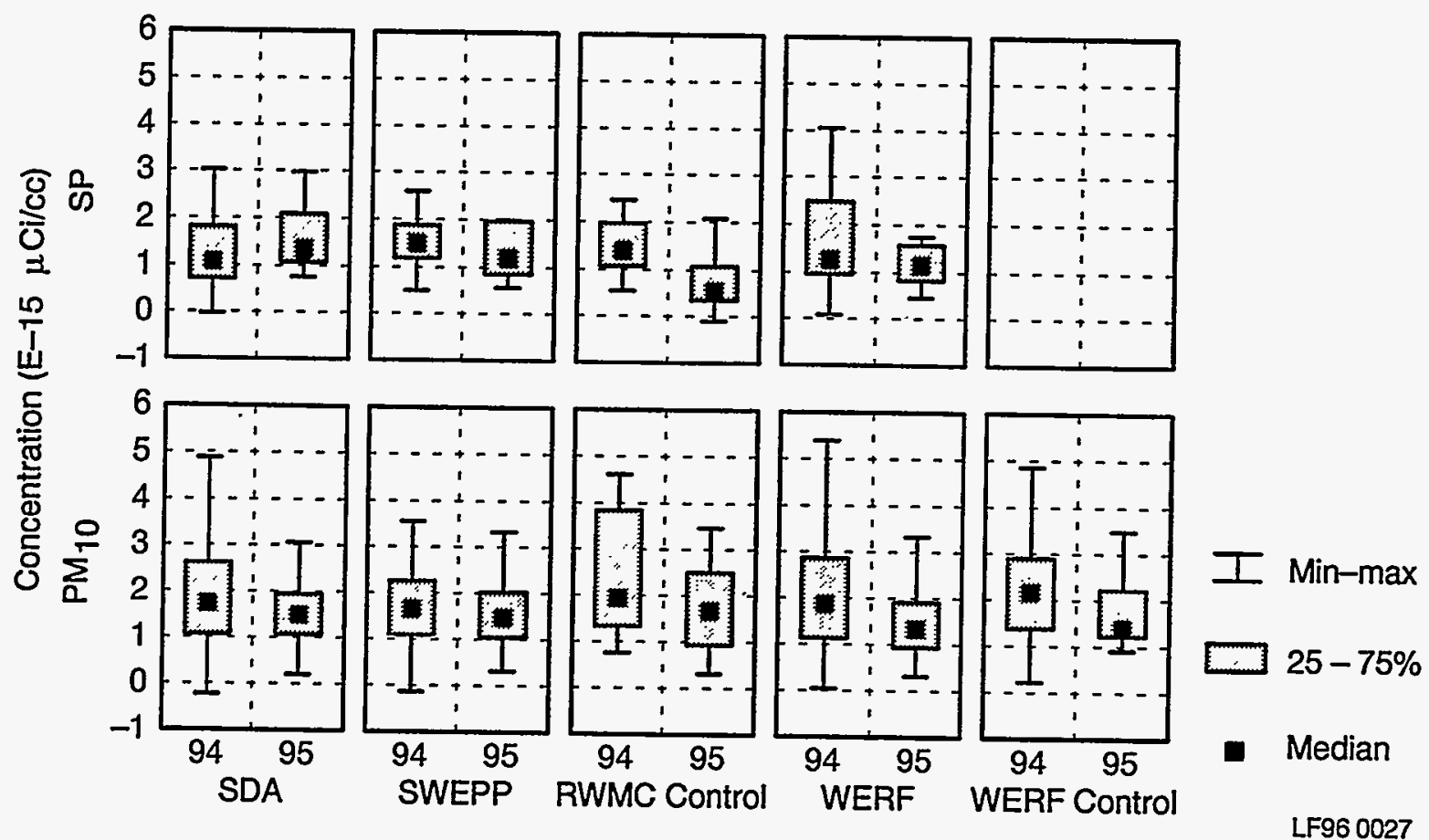

Figure 18. 1994 and 1995 box and whisker plots of the gross-alpha concentrations (non-outlier) by facility and monitor type.

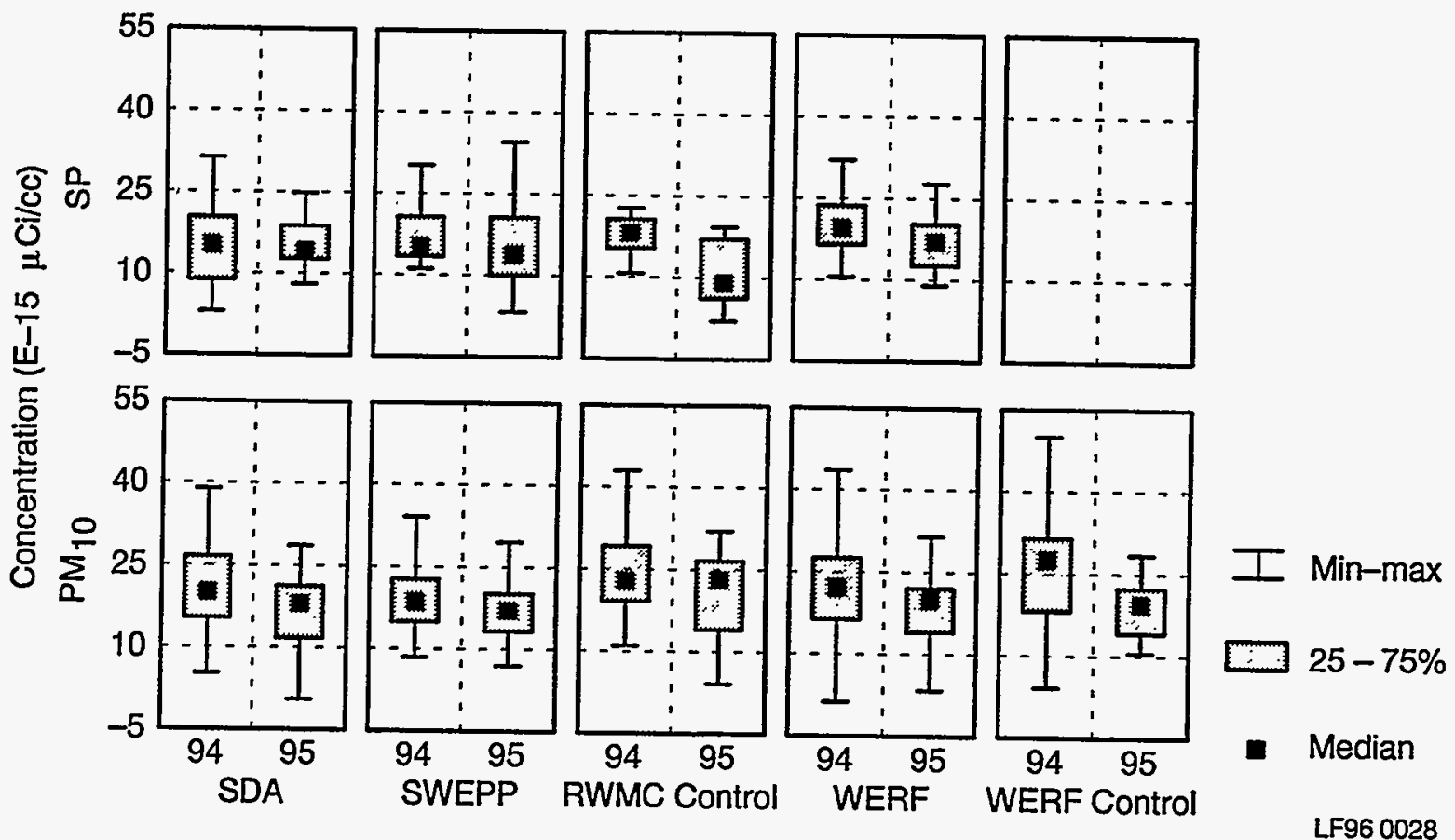

Figure 19. 1994 and 1995 box and whisker plots of the gross-beta concentrations (non-outlier) by facility and monitor type. 


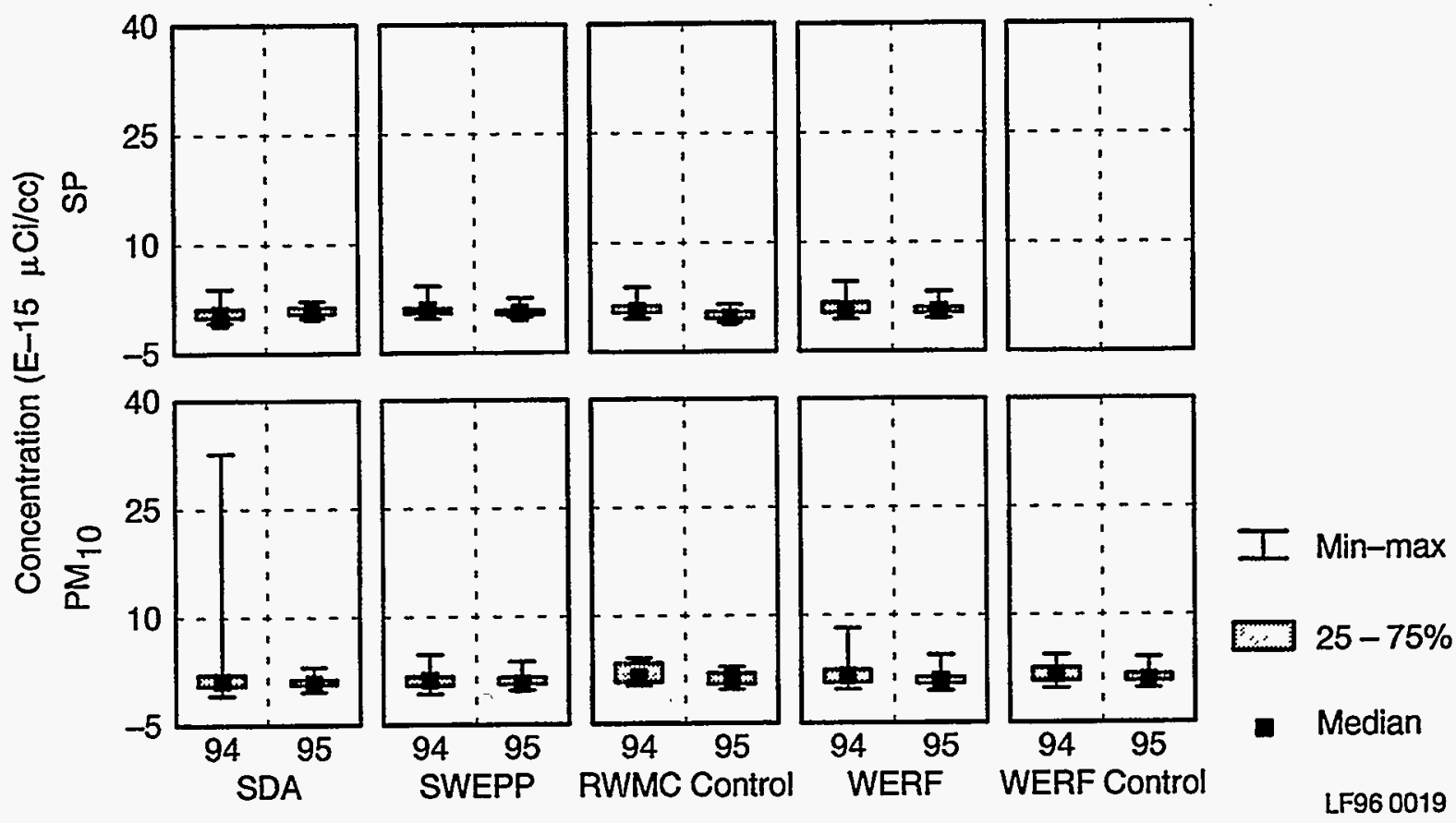

Figure 20. 1994 and 1995 box and whisker plots of the gross-alpha concentrations (outlier) by facility and monitor type.

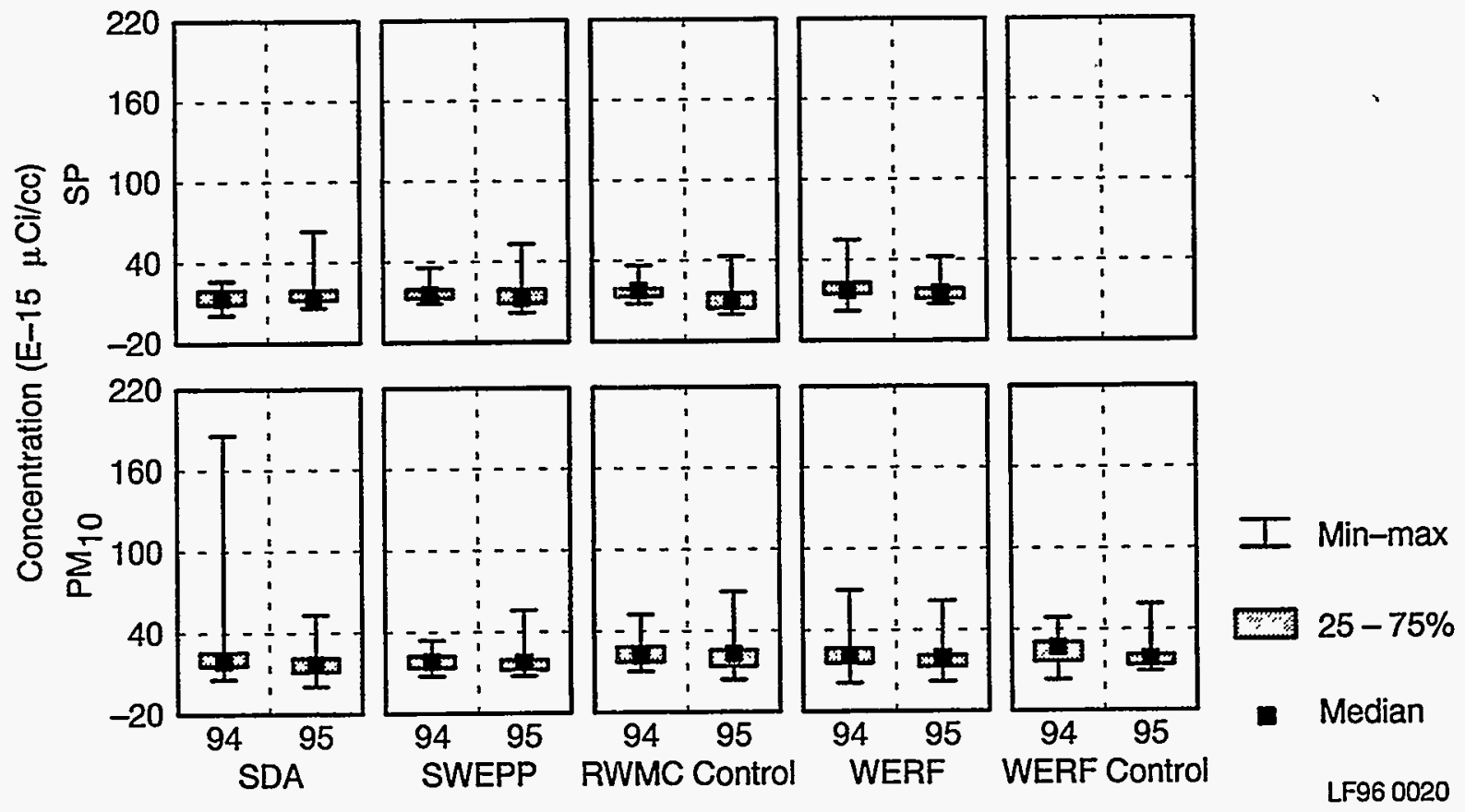

Figure 21. 1994 and 1995 box and whisker plots of the gross-beta concentrations (outlier) by facility and monitor type. 
Table 2. Summary statistics for gross-alpha concentrations ( $\mathrm{E}-15 \mu \mathrm{Ci} / \mathrm{cc}$ ).

\begin{tabular}{clcccccc}
\hline $\begin{array}{c}\text { Monitor } \\
\text { Type }\end{array}$ & Facility & Year & N & Mean & Median & Minimum & Maximum \\
\hline SP & SDA & 94 & 24 & 1.4 & 1.1 & 0.0 & 4.5 \\
& & 95 & 22 & 1.5 & 1.4 & 0.8 & 3.0 \\
& SWEPP & 94 & 31 & 1.8 & 1.5 & 0.5 & 5.2 \\
& & 95 & 42 & 1.3 & 1.2 & 0.6 & 3.2 \\
& WERF & 94 & 23 & 2.8 & 1.3 & 0.1 & 5.2 \\
& & 95 & 24 & 2.3 & 1.2 & 0.5 & 3.8 \\
& SWEPP & 94 & 21 & 1.6 & 1.4 & 0.6 & 4.4 \\
& Control & 95 & 22 & 1.78 & 1.6 & -0.08 & 2.1 \\
PM $_{10}$ & SDA & 94 & 154 & 2.2 & 1.7 & -0.3 & 33.0 \\
& & 95 & 156 & 1.5 & 1.4 & -0.1 & 3.6 \\
& SWEPP & 94 & 92 & 1.8 & 1.6 & -0.2 & 5.3 \\
& & 95 & 92 & 1.5 & 1.4 & 0.3 & 4.0 \\
& WERF & 94 & 64 & 2.3 & 1.8 & 0.0 & 8.5 \\
& & 95 & 72 & 1.5 & 1.3 & 0.3 & 5.0 \\
& SWEPP & 94 & 23 & 2.4 & 1.9 & 0.7 & 4.6 \\
& Control & 95 & 22 & 1.7 & 1.6 & 0.3 & 3.5 \\
& WERF & 94 & 24 & 2.2 & 2.2 & 0.2 & 4.9 \\
& Control & 95 & 23 & 1.8 & 1.4 & 0.9 & 4.5 \\
\hline
\end{tabular}

Table 3. Summary statistics for gross-beta concentrations (E-15 $\mu \mathrm{Ci} / \mathrm{cc})$.

\begin{tabular}{llllcrrc}
\hline $\begin{array}{c}\text { Monitor } \\
\text { Type }\end{array}$ & Facility & Year & N & Mean & Median & Minimum & Maximum \\
\hline SP & SDA & 94 & 24 & 15.4 & 15.4 & 3.1 & 31.4 \\
& & 95 & 22 & 16.5 & 14.2 & 8.0 & 43.1 \\
& SWEPP & 94 & 31 & 17.7 & 15.4 & 11.1 & 36.2 \\
& & 95 & 42 & 16.4 & 13.8 & 3.5 & 53.7 \\
& WERF & 94 & 23 & 21.1 & 19.6 & 4.2 & 56.0 \\
& & 95 & 24 & 17.8 & 17.2 & 9.2 & 43.9 \\
& SWEPP & 94 & 21 & 18.5 & 18.2 & 10.8 & 37.8 \\
& Control & 95 & 22 & 12.2 & 9.2 & 2.0 & 44.1 \\
$\mathrm{PM}_{10}$ & SDA & 94 & 154 & 22.3 & 20.1 & 5.4 & 186.0 \\
& & 95 & 156 & 17.6 & 18.0 & 0.5 & 53.7 \\
& SWEPP & 94 & 92 & 19.1 & 18.5 & 8.5 & 33.7 \\
& & 95 & 92 & 18.4 & 17.0 & 7.1 & 56.3 \\
& WERF & 94 & 65 & 22.6 & 22.1 & 1.4 & 70.0 \\
& & 95 & 72 & 20.5 & 20.0 & 3.5 & 61.7 \\
& SWEPP & 94 & 23 & 25.6 & 22.9 & 10.7 & 53.0 \\
& Control & 95 & 22 & 22.6 & 23.2 & 4.1 & 69.8 \\
& WERF & 94 & 24 & 25.7 & 27.4 & 4.1 & 50.0 \\
& Control & 95 & 23 & 21.1 & 19.6 & 10.7 & 59.2 \\
\hline
\end{tabular}


in gross-alpha concentrations reported for the remaining monitors were found to be statistically significant.

In general, slight decreases in the median gross-beta values from 1994 to 1995 were seen for both $\mathrm{PM}_{10}$ and SP monitors at all facilities (see Figures 19 and 21). The exception to this was for the $\mathrm{PM}_{10}$ monitors at the SWEPP control location where a slight increase was seen. The Kruskal-Wallis test indicated that the only statistically significant median changes occurred with the $\mathrm{PM}_{10}$ monitors located at the SDA, SWEPP, SWEPP control location; and the SP monitor located at the SWEPP control location.

\subsubsection{Radioactive Waste Management Complex}

Figure 9 shows the sampling locations of both RESP and SESP air monitors at the RWMC. EG\&G Idaho has measured gross-beta activity from 1979 through 1993, and Lockheed Martin Idaho has measured this activity since 1994. Quarterly averages of RWMC gross-beta activity (Cs-137 equivalent) since 1985 are given in Figure 22. The rise in beta activity in 1986 is attributed to the fallout from the April 1986 Chernobyl açcident in the Soviet Union.

Figures 23 and 24 show the gross-beta concentration (Cs-137 equivalent) trends at the SDA and SWEPP, respectively, during each semimonthly sampling period during 1995 . The gross-beta data have historically followed a seasonal trend that usually increases during the latter part of the year.

Monthly averages of SESP LV air samples at the RWMC for gross-beta activity are given in Figure 25. SESP data (monthly averages) and RESP data (quarterly averages shown in Figure 22) show similar trends.

Analysis for Gamma-Emitting Radionuclides. Gamma-emitting radionuclides that could be present due to RWMC operations were not detected in either the RESP or SESP air samples collected at the RWMC in 1995. (Radionuclides most likely to be found at the RWMC, and detection limits are listed in Table B-2.)

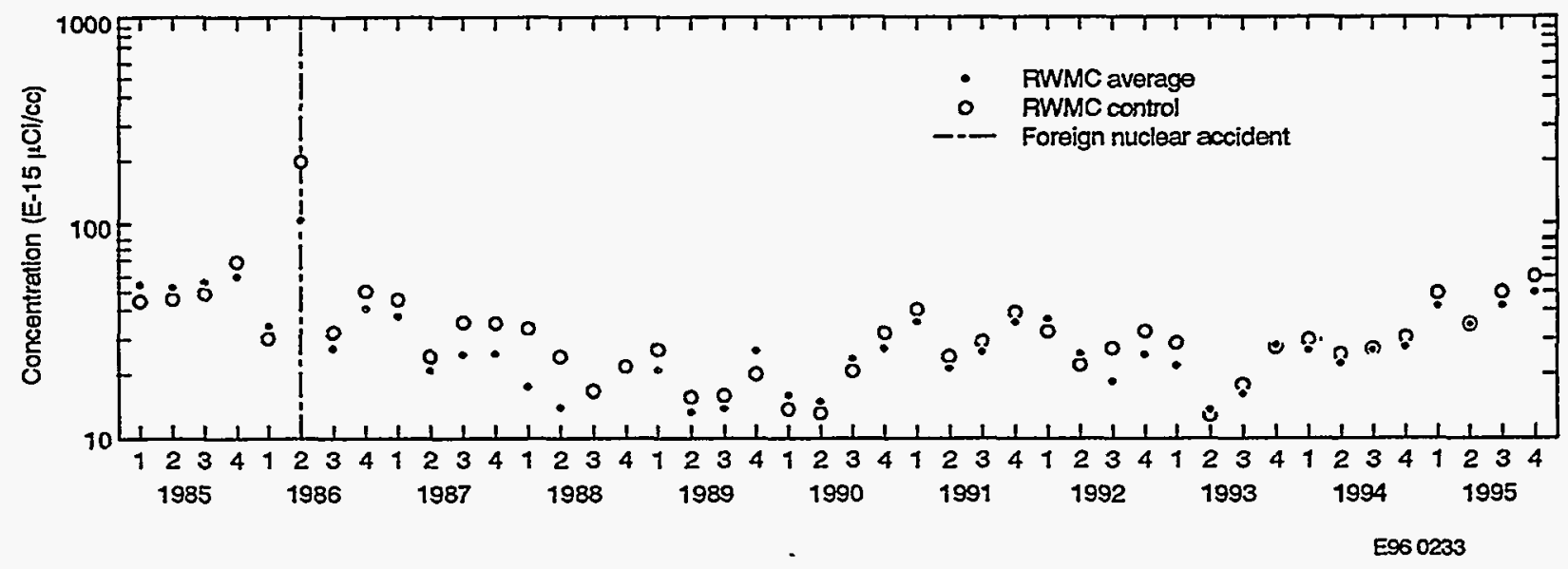

Figure 22. Quarterly averages of RWMC gross-beta air concentrations since 1985. 


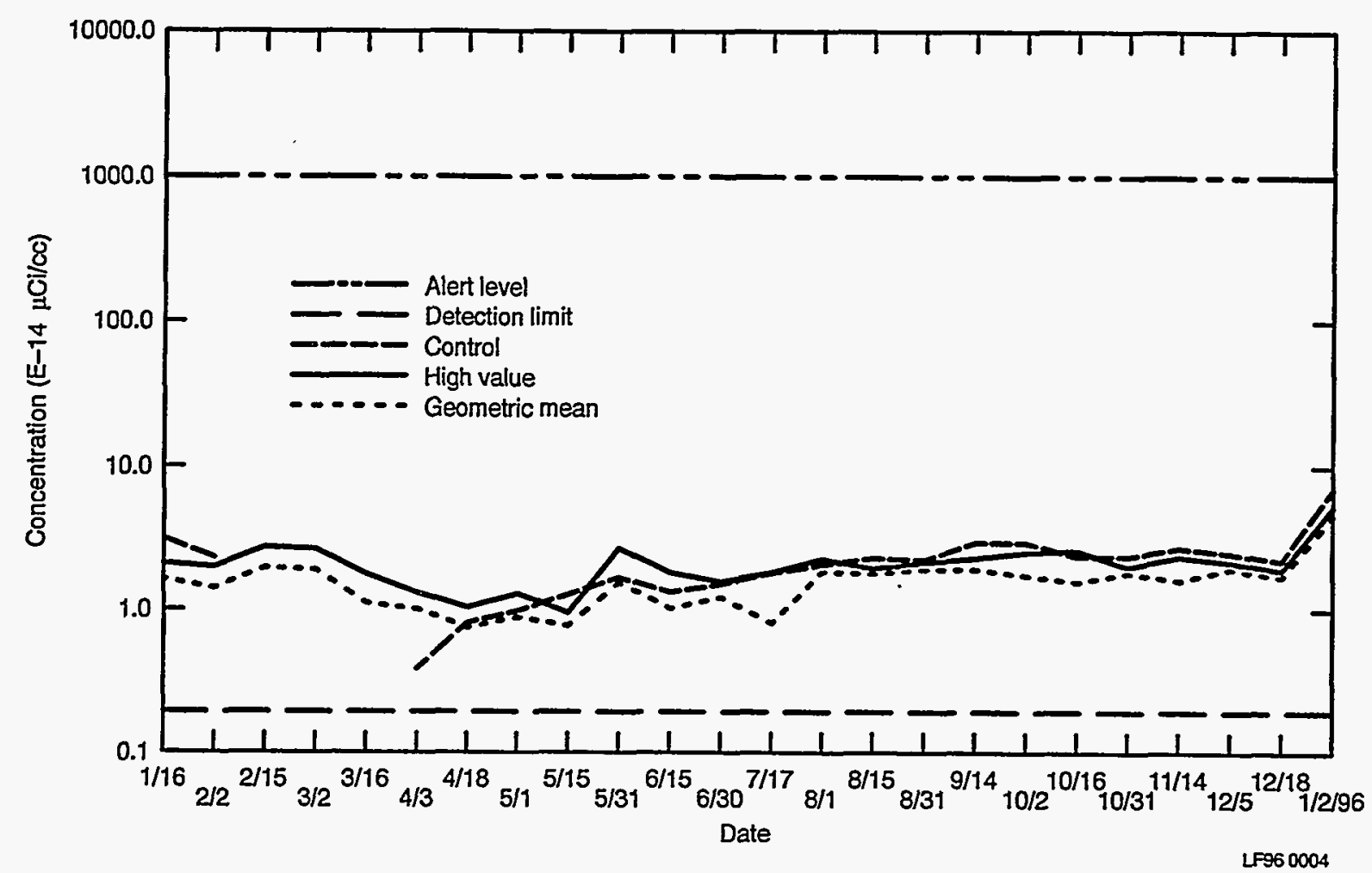

Figure 23. Gross-beta concentration (Cs-137 equivalent) trends for SDA air filters during each semimonthly period of 1995 .

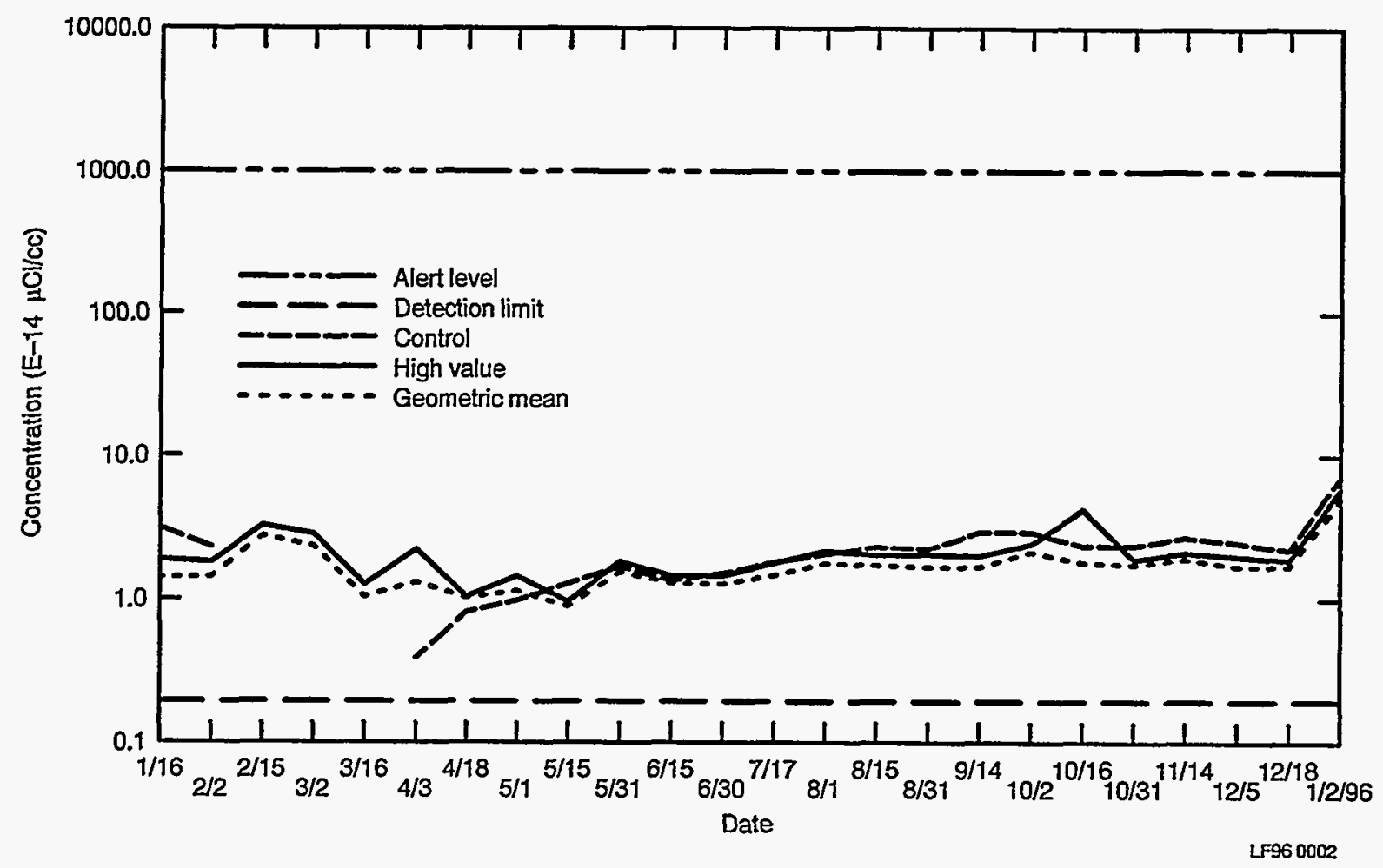

Figure 24. Gross-beta concentration (Cs-137 equivalent) trends for SWEPP air filters during each semimonthly period of 1995 . 


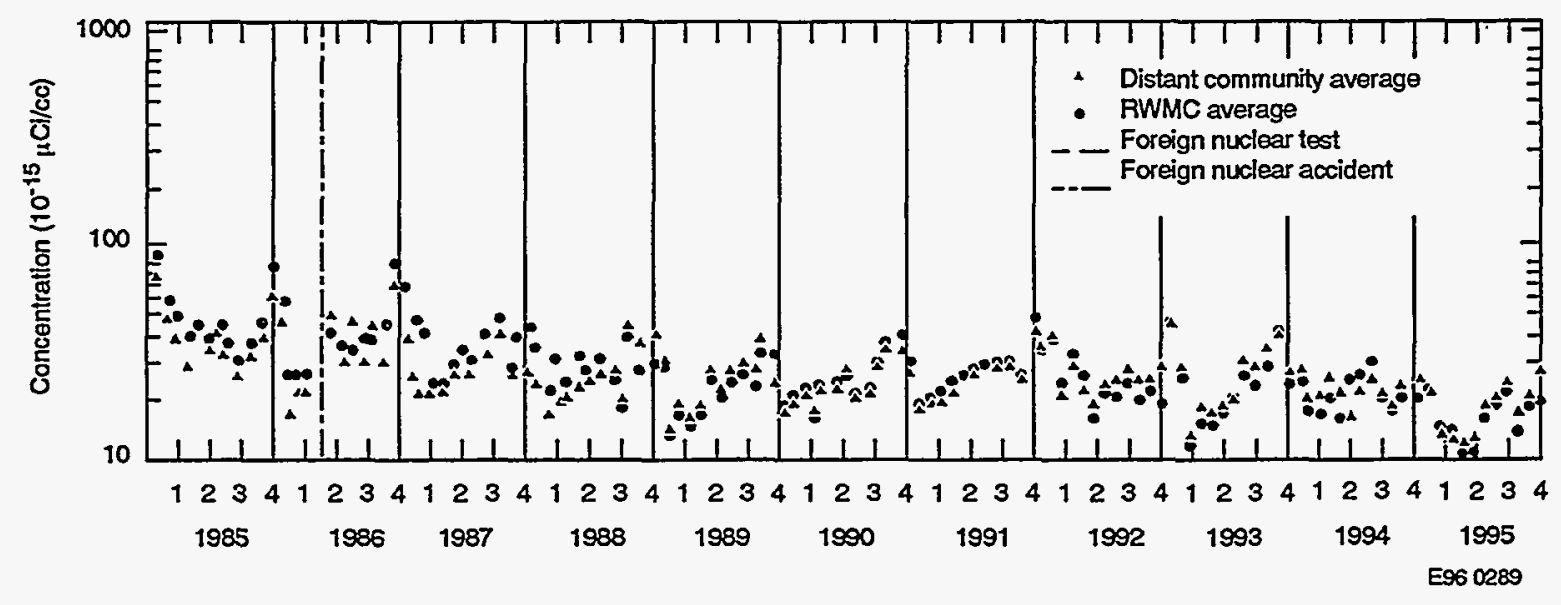

Figure 25. SESP monthly average gross-beta concentrations (LV air monitors).

Analysis for Specific Alpha- and Beta-Emitting Radionuclides. Only four data points for specific alpha- and beta-emitters are collected per location in any year, with results frequently less than the detection limit. In general, trend information cannot be developed over a one-year period, nor is it possible to obtain information regarding the time of a release within a one-quarter period. Analysis of quarterly composited air samples indicates the effectiveness of waste confinement. Figure 26 shows a plot of Am-241 and Pu-239, -240 concentrations measured at all RWMC locations since the first quarter of 1986 and their association to the appropriate DCG. In accordance with DOE Order 5400.5, the DCG for Am-241 and Pu-239, -240 is $2.0 \mathrm{E}-14 \mu \mathrm{Ci} / \mathrm{mL}$.

During the first quarter, Sr-90 was detected at TSA locations 21.3, 22.3 (see Figure 9), and the WERF control location 603.3 (see Figure 11). The maximum concentration was detected at the control location and was $7.0 \pm 1.6 \mathrm{E}-17 \mu \mathrm{Ci} / \mathrm{cc}$. This represents $0.001 \%$ of the applicable DCG and compares to past concentrations seen in this area.

Specific alpha data was invalidated for the second quarter because of evidence of cross-contamination during analysis. Invalidating data was based on quality control (QC) sample results submitted with the data set (see Appendix A).

During the third quarter, Am-241 was detected at locations 2.3 and 2.0. The maximum concentration was $2.0 \pm 0.3 \mathrm{E}-17 \mu \mathrm{Ci} / \mathrm{cc}$. This represents $0.1 \%$ of the applicable DCG. These concentrations are consistent with those seen in the.past. $\mathrm{Pu}-238$ was detected at locations $1.3,4.2$, 21.3 , and 26.0. The maximum concentration was $2.0 \pm 0.3 \mathrm{E}-17 \mu \mathrm{Ci} / \mathrm{cc}(0.07 \%$ of the applicable DCG) at location 4.2. Pu-239, -240 was also seen at locations $1.3,2.0,4.2$, and 21.3. The maximum $\mathrm{Pu}-239,-240$ concentration was $7.4 \pm 0.9 \mathrm{E}-17 \mu \mathrm{Ci} / \mathrm{cc}(0.37 \%$ of the applicable DCG) at location 4.2 . Airborne $\mathrm{Pu}-238$ and Pu-239, -240 were measured during the mid-1980s at these levels and greater. Only a few detections were noted between the mid-1980s and the third quarter of 1995.

Sr-90 was detected during the third quarter at locations $2.3,22.3,26.3$, and 603.3. The maximum concentration occurred at location 26.3 and was $8.0 \pm 1.6 \mathrm{E}-17 \mu \mathrm{Ci} / \mathrm{cc}$. This represents $0.001 \%$ of the applicable DCG. Concentrations at these levels have also been seen in the past. 


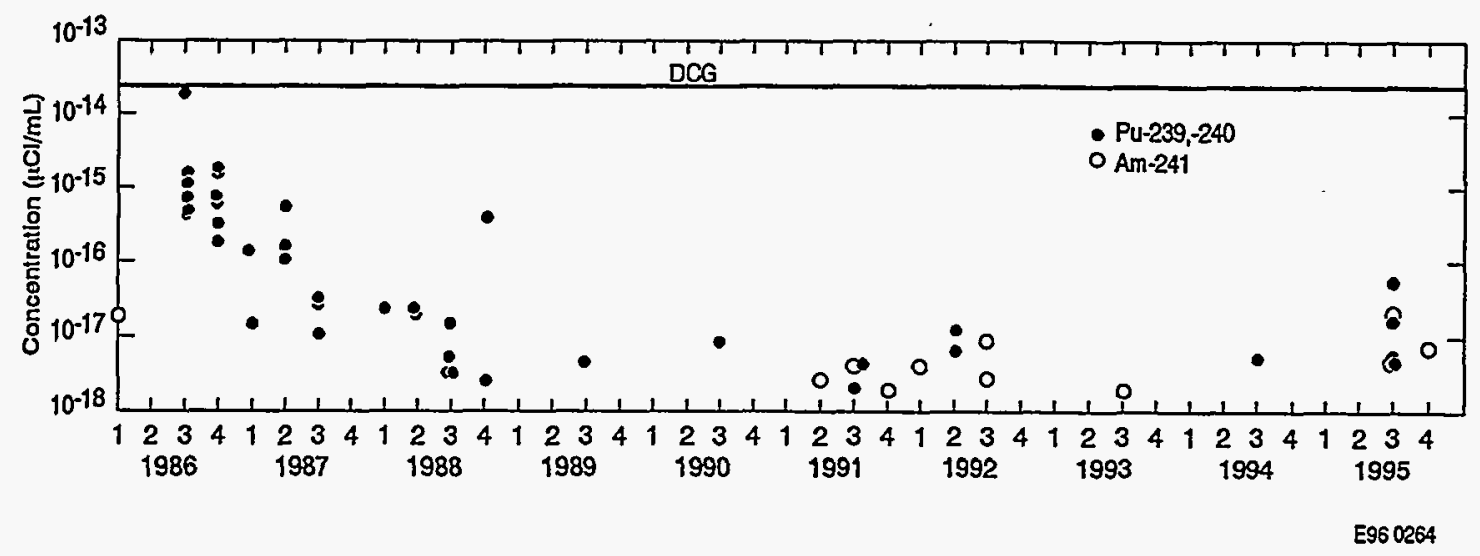

Figure 26. Am-241 and Pu-239, -240 quarterly composite concentrations for air filters at RWMC locations. Second quarter 1995 data was invalidated (see Appendix A).

During the fourth quarter of $1995, \mathrm{Sr}-90$ was detected at locations 9.3 and 26.3. The maximum concentration was $1.4 \pm 0.2 \mathrm{E}-16 \mu \mathrm{Ci} / \mathrm{cc}$. This is $0.002 \%$ of the applicable DCG and was found at location 9.3. These concentrations of airborne St-90 are comparable to previous measurements of $\mathrm{Sr}-90$ around the RWMC. The only other alpha-emitting radionuclide detected was Am-241 at location 2.0 in the fourth quarter. The concentration was $8.0 \pm 1.9 \mathrm{E}-18 \mu \mathrm{Ci} / \mathrm{cc}$ and represents $0.04 \%$ of the applicable DCG. This concentration compares with past Am-241 concentrations reported in the past at the northeast corner.

\subsubsection{Waste Experimental Reduction Facility}

The air monitoring locations around WERF are shown in Figure 10, and the control location is shown in Figure 11. The quarterly average of gross-beta activity for the WERF is shown graphically in Figure 27. The unusually high gross-beta results observed in 1986 are attributed to the Chernobyl accident.

Figure 28 shows the maximum gross-beta activity concentrations and mean gross-beta activity at WERF for each semimonthly period. Monthly mean concentrations were not statistically different from those reported for the control location.

During 1995, there were no detections above background of gamma-emitting radionuclides in WERF monthly air sample composites. Since no known source of TRU radionuclides exists in this area, no specific alpha analyses were performed.

\subsubsection{Mixed Waste Storage Facility}

Figure 10 shows the location of the air monitor at the MWSF. This monitor was installed in October 1986. Airborne gross-alpha and -beta concentrations were measured at normal ambient levels during 1995 (see Figure 29). Man-made, gamma-emitting radionuclides were not detected at the MWSF during 1995. Specific alpha analyses were not performed because no known source of TRU radionuclides exists in this area. 


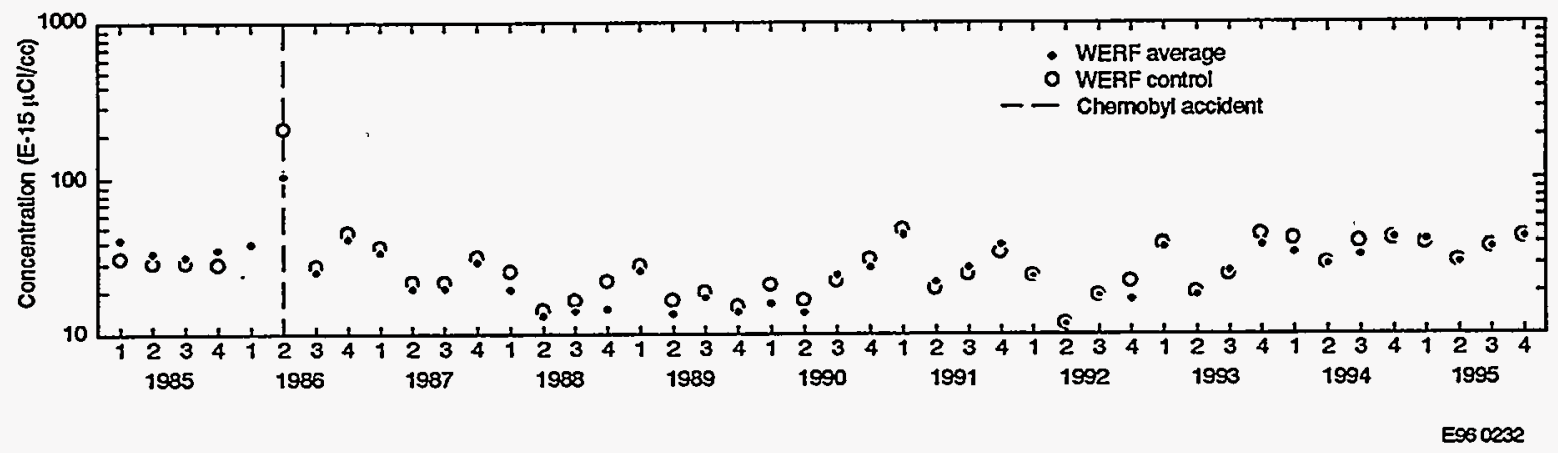

Figure 27. Quarterly average of gross-beta air concentrations measured at WERF.

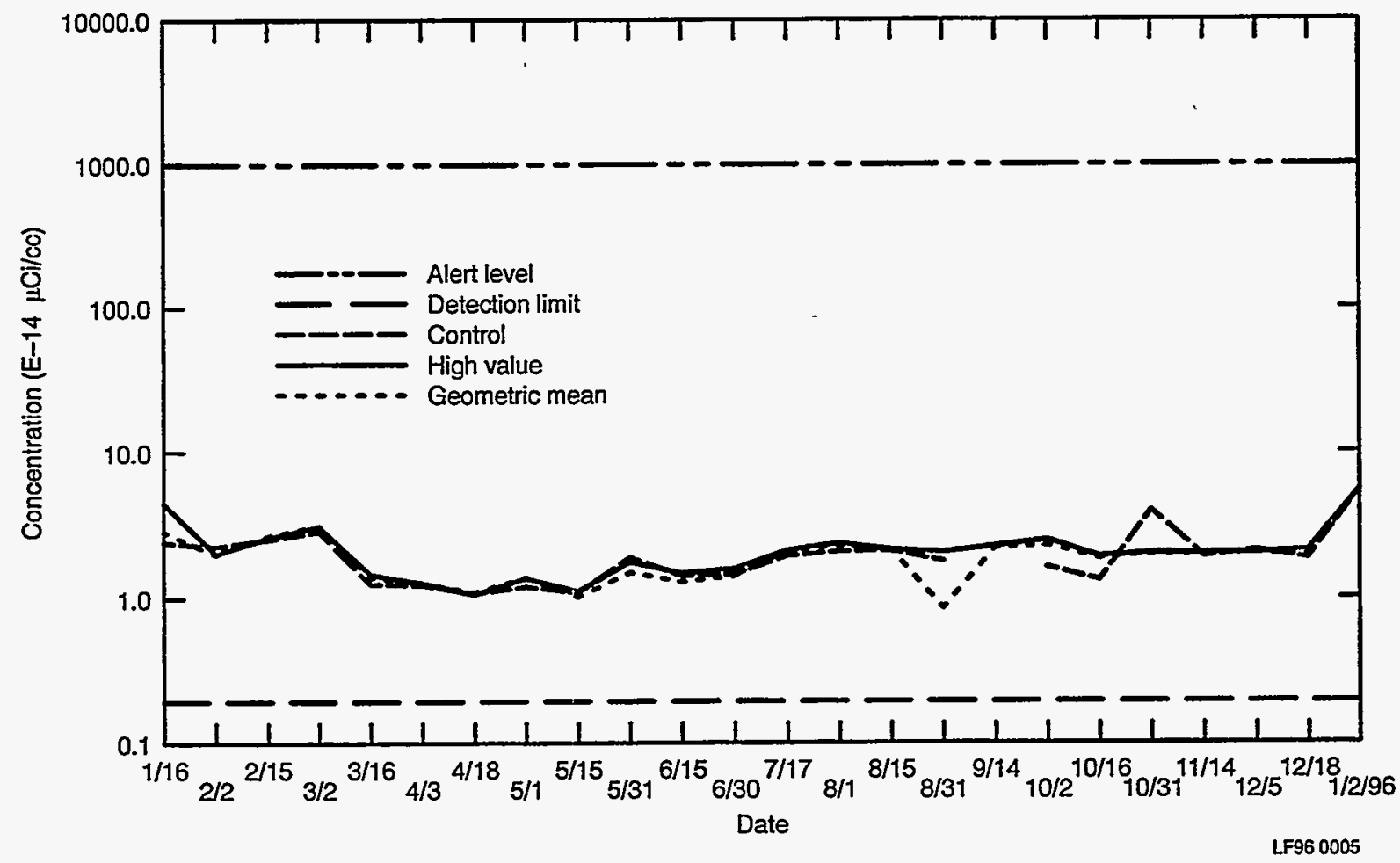

Figure 28. Maximum gross-beta concentrations (Cs-137 equivalent) for WERF air filters during each semimonthly period of 1995 . 


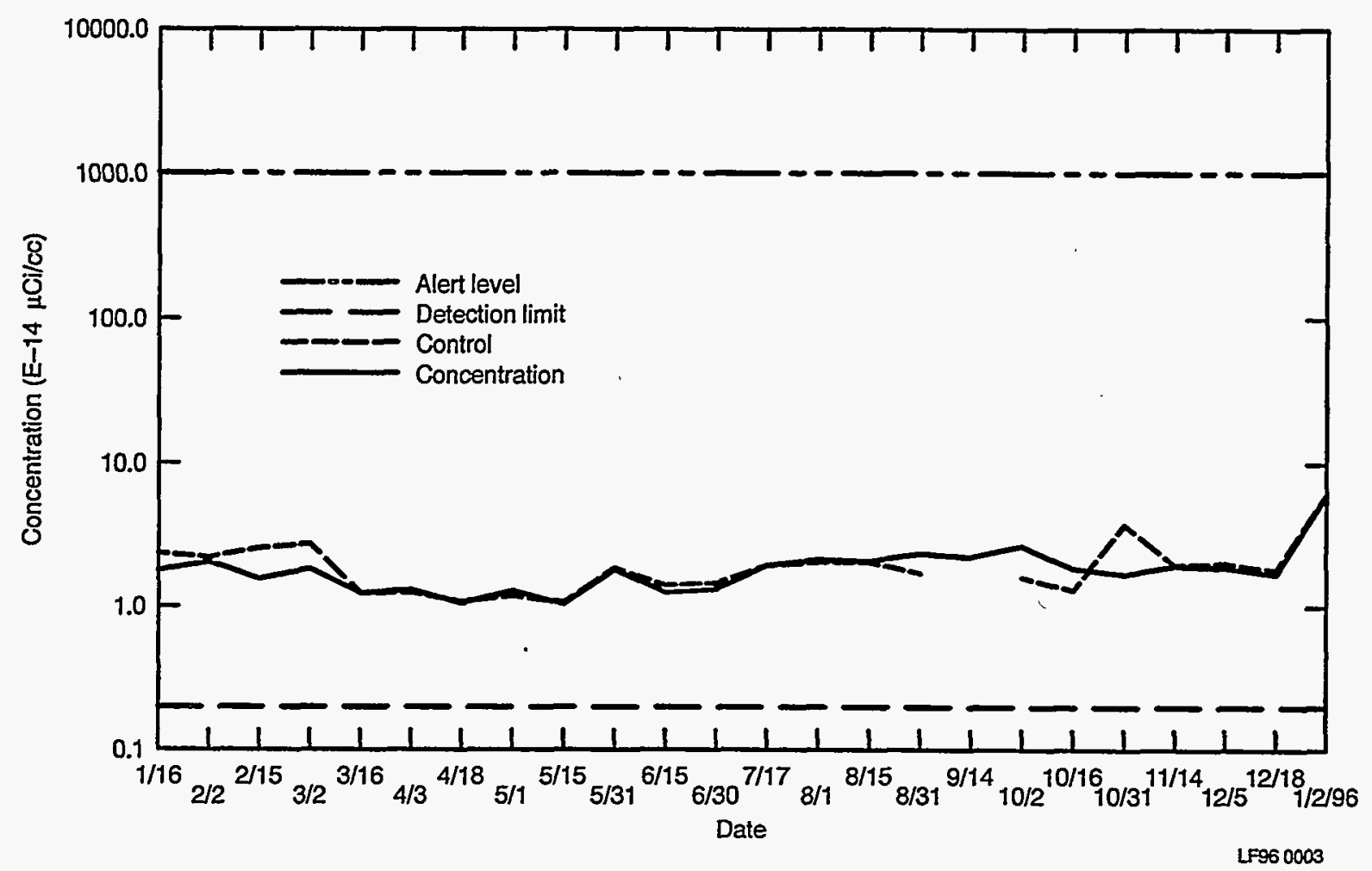

Figure 29. Maximum gross-beta concentrations (Cs-137 equivalent) for MWSF air filters during each semimonthly period of 1995 .

\subsection{Surface Runoff}

Surface runoff is defined as the water from heavy rains or melted snow that flows over the surface. The specific objectives of surface runoff sampling are to (a) determine concentrations of radionuclides in any surface water leaving INEL Waste Management Facilities, (b) report comparisons of measured concentrations against reference levels based on DCGs for the public given in DOE Order 5400.5, and (c) detect and report significant trends in measured concentrations of radionuclides in surface waters leaving INEL Waste Management Facilities.

Each sample was collected in a 4- polyethylene container and preserved with acid. Filter paper pulp tablets were added, and the container was then sealed, dated, and identified by location. The Radiation Measurements Laboratory (RML) analyzed the samples by means of gamma spectrometry, which was performed on both liquid and particulate fractions. Second quarter samples were also submitted for radiochemical analysis. Detection limits for specific radionuclides, including those most likely to be found at the RWMC, are listed in Tables B-1, B-2, and B-3.

\subsubsection{Radioactive Waste Management Complex}

Radionuclides could be transported outside the boundaries of the RWMC via surface runoff. Surface runoff occurs at the SDA only during periods of snowmelt or heavy precipitation. At these times, water is pumped out of the SDA into a drainage canal. Water also runs off of the asphalt pads around TSA and into drainage culverts and the drainage canal, which directs the flow outside the RWMC. The canal carries outside runoff that has been diverted around the RWMC. Ponding of the * runoff in a few low areas may increase subsurface saturation, enhancing subsurface migration. 
Water samples are collected during each quarter when sufficient rain falls or snow melts to produce runoff from the TSA asphalt pads and in the SDA gate ditch. One sample is collected from each of the four culverts that drain off of the TSA asphalt pads. These four sampling points are upstream from a drainage ditch. In addition, a sample is taken at the point of discharge from the SDA near the sump pump.

Figure 30 shows the collection of a surface runoff sample at the RWMC. Surface runoff draining from the SDA is pumped into the SDA/TSA drainage ditch. Sampling at this point allows a direct assessment of radionuclide migration from the SDA via surface runoff. Sampling at the TSA-1, TSA-2, TSA-3, and TSA-4 culverts (see Figure 31) allows similar assessments of these areas. Control samples are collected to determine background concentrations of the radionuclides of interest at locations unaffected by facility operations. The control location is a ponding area $1.9 \mathrm{~km}(1.2 \mathrm{mi})$ north of the RWMC (T-12 Road) and is currently being compared to samples collected at the SDA. The control location established at the rest area on Highway 20 is used for samples collected at the TSA Pad. These locations represent the asphalt or soil surface types (see Figure 32).

Surface runoff samples were collected during the first, second, and fourth quarters of 1995 . No man-made, gamma-emitting radionuclides were detected during 1995 in any of the samples collected.

Surface runoff samples were also submitted during the second quarter and analyzed for specific alpha- and beta-emitting radionuclides. Sr-90 was detected in samples collected at TSA-3, TSA-4, SDA, and the control location at the T-12 road. The maximum concentration detected was $9.0 \pm 1.3 \mathrm{E}-10 \mu \mathrm{Ci} / \mathrm{mL}$ at TSA-4, which represents $0.09 \%$ of the applicable DCG in water. Though Sr-90 is not typically seen in runoff, it is typically detected in surface soils in this area. Due to the increased runoff during 1995 after a drought period, there was an increase in the amount of suspended particulates in the runoff waters collected. Also, see Section 2.1 for discussion on the increased number of positive detections.

$\mathrm{Pu}-239,-240$ was detected at TSA-4 and the SDA. The maximum concentration was $4.0 \pm$ $1.3 \mathrm{E}-11 \mu \mathrm{Ci} / \mathrm{mL}$, which represents $0.13 \%$ of the applicable DCG. Am-241 was also detected at SDA TSA-2, and TSA-4. The maximum Am-241 concentration was $1.3 \pm 0.2 \mathrm{E}-10 \mu \mathrm{Ci} / \mathrm{mL}(0.4 \%$ of the applicable DCG) and was found at the SDA. These concentrations are comparable to those seen in previous years.

\subsubsection{Waste Experimental Reduction Facility}

In the fall of 1994, RESP began collecting quarterly surface runoff samples at the WERF seepage basins (Figure 33). No specific radiochemical analysis was performed on these samples since no source term exists at WERF for these nuclides.

Samples were collected during the first, second, and fourth quarters and were submitted for gamma spectrometry. No man-made, gamma-emitting radionuclides were detected in any of these samples.

\subsection{Soils}

Soil samples help detect potential changes in soil concentrations caused by surface deposits of airborne contamination and help detect the loss of waste confinement. Measurement of surface deposition over a large area, that is relative to the area represented by a soil sample, provides a better indication of waste confinement and potential soil contamination. 


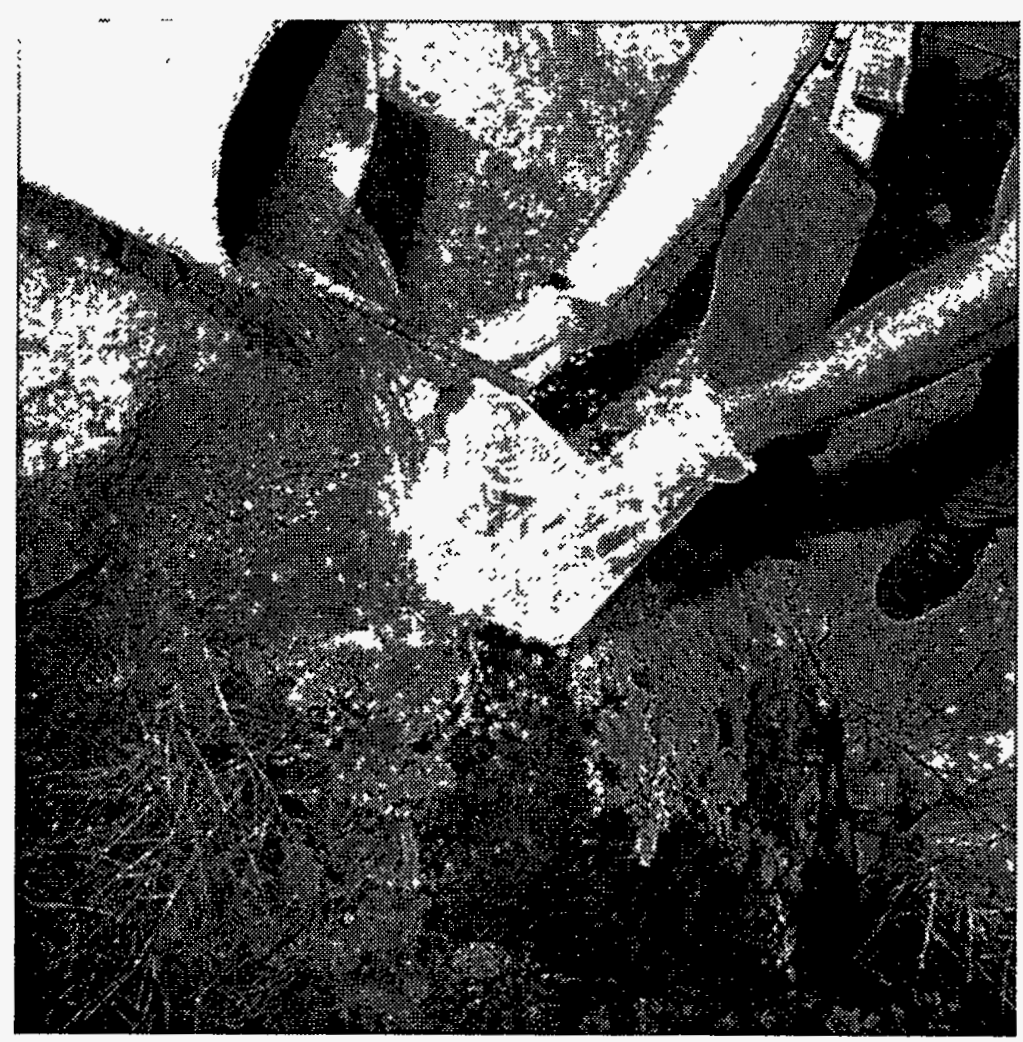

Figure 30. RWMC surface runoff collection (photo number 91-317-1-1).

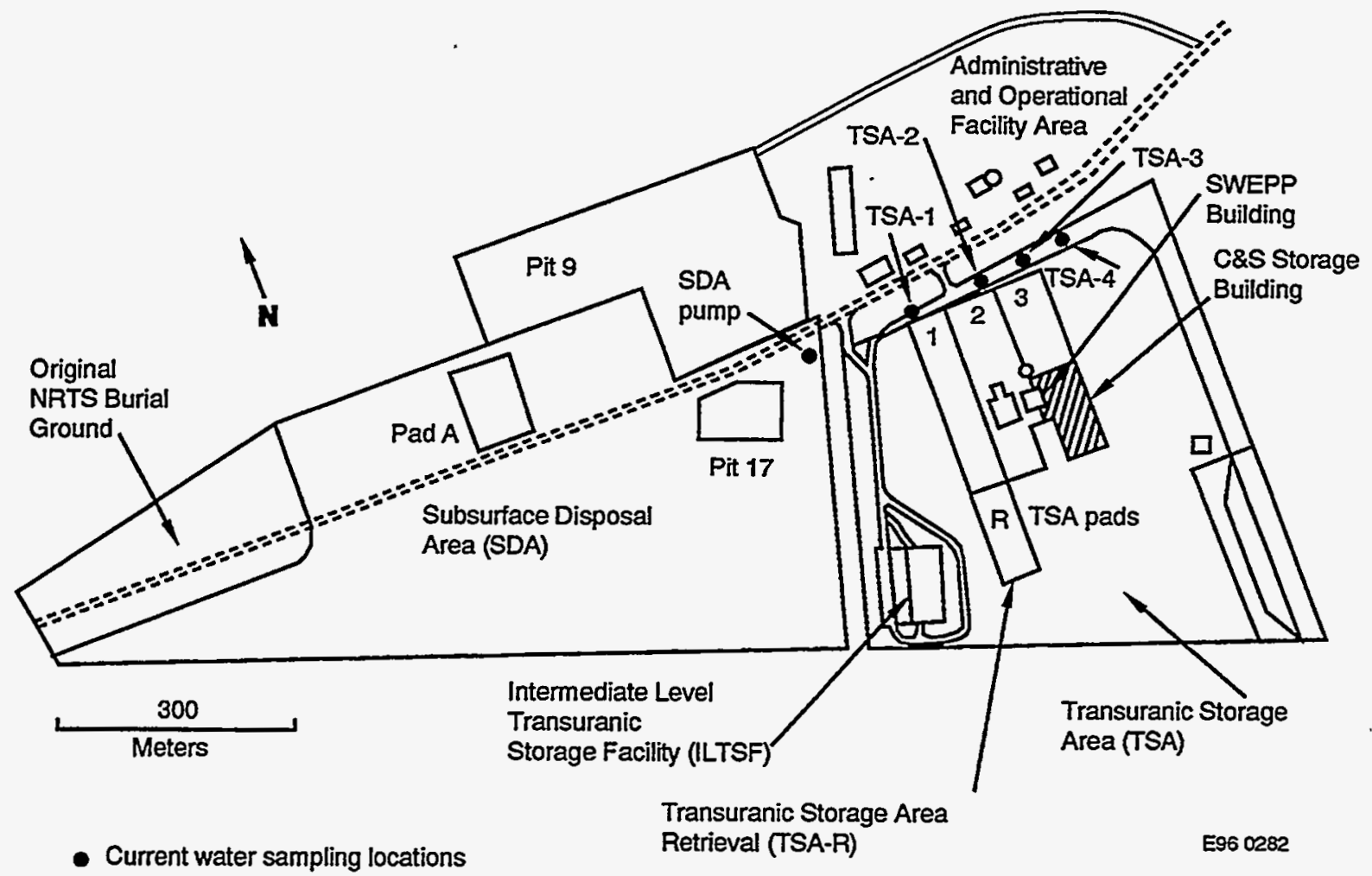

Figure 31. Sampling locations for surface runoff. 


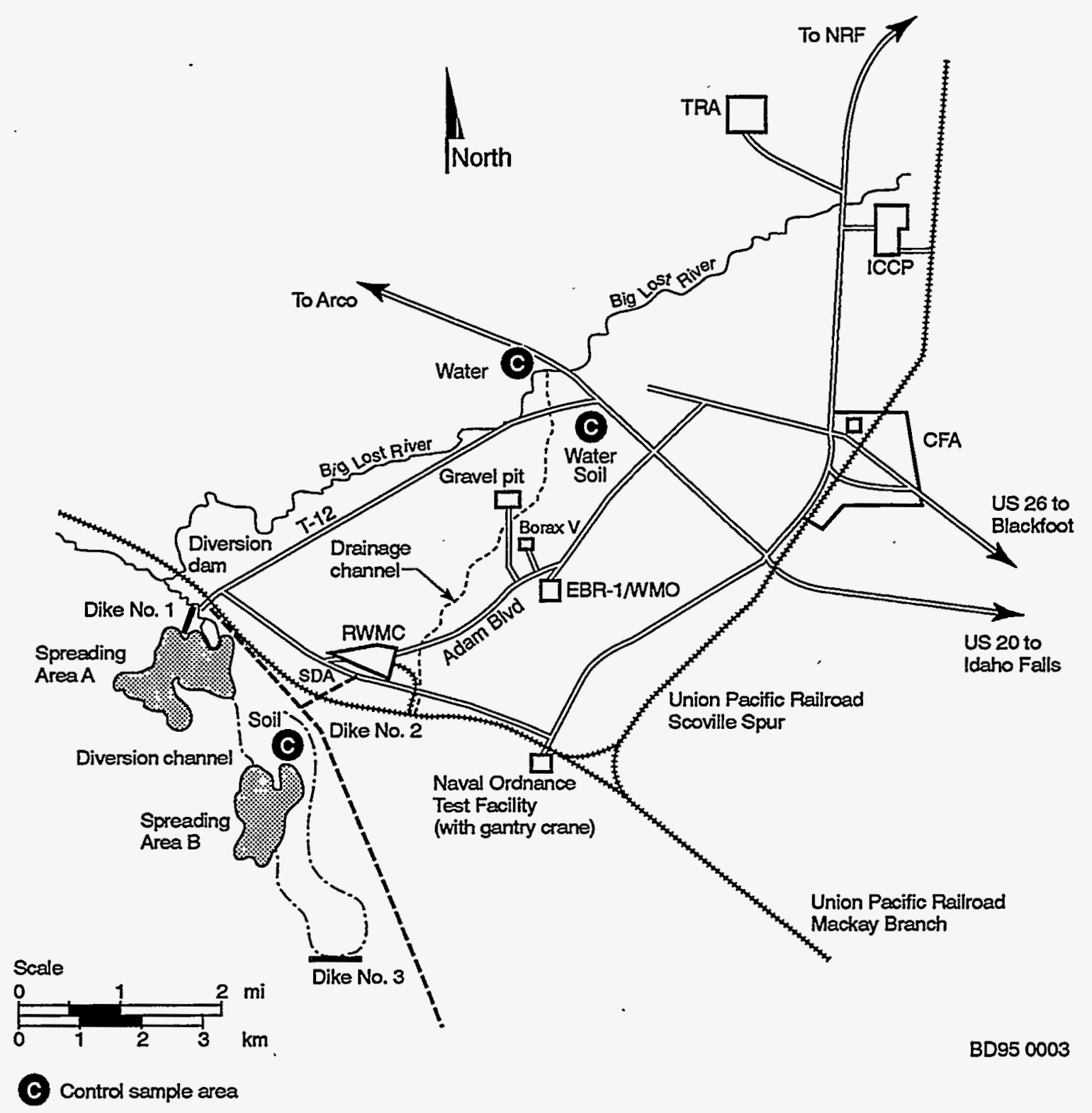

Figure 32. Water and soil control locations. 


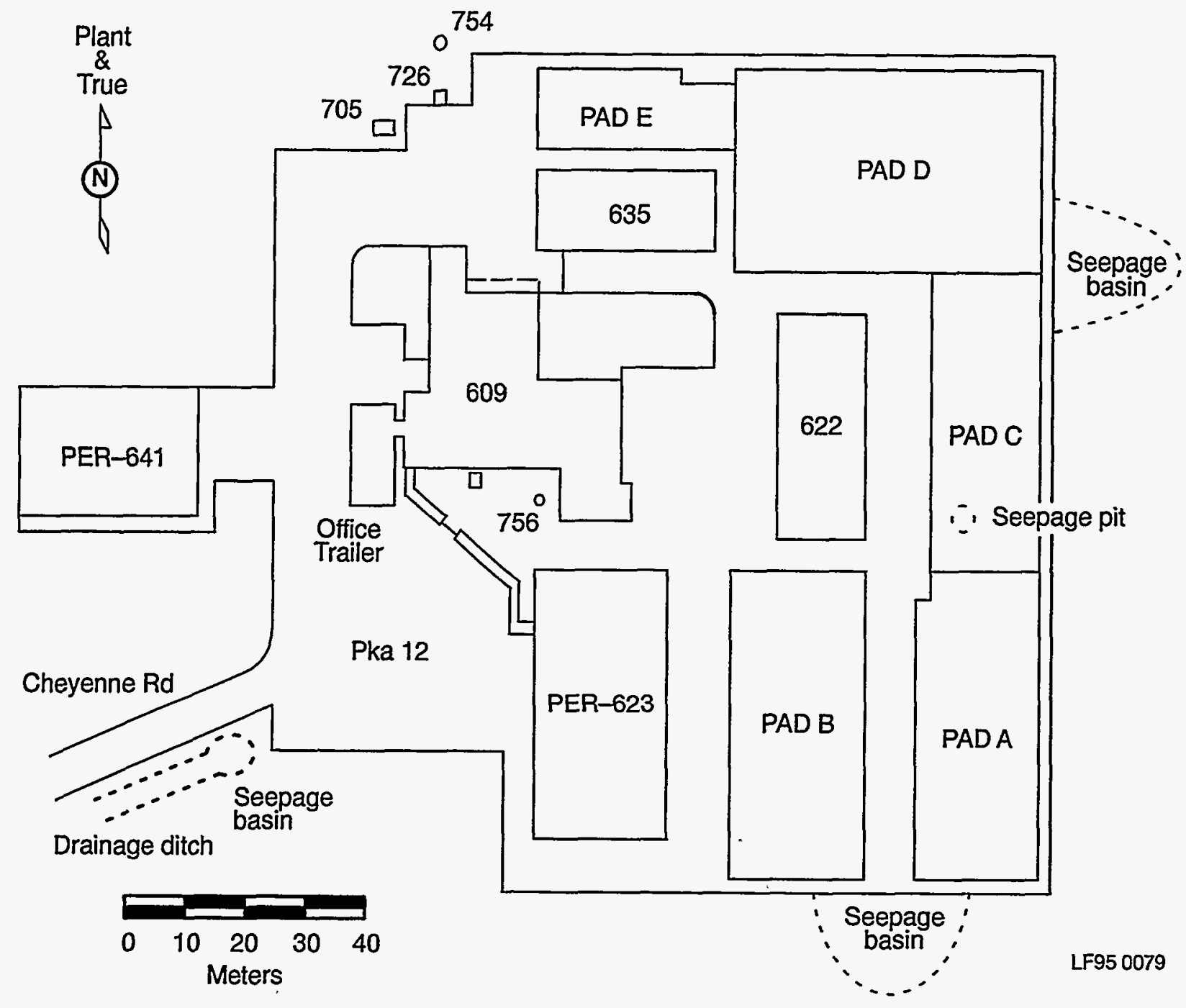

Figure 33. WERF surface runoff sampling locations.

The specific objectives of surface soil sampling activity are to determine concentrations of radionuclides in soils in the vicinity of INEL Waste Management Facilities and to detect and report significant trends in measured concentrations of radionuclides in soils.

At each sampling station, a soil sample is collected at each of the four corners of a $10 \times 10-\mathrm{m}$ $(11 \times 11 \mathrm{yd})$ square and at the center of the square. The samples are then combined to form a single composite sample. A stainless-steel sampling ring and scoop are used to collect a 12-cm (4.7 in) diameter $\times 5-\mathrm{cm}(2$ in) deep sample from these soils (see Figure 34 ).

The samples are dried, weighed, homogenized (ball-milled), screened through a number 35 sieve, and then analyzed by gamma spectrometry and radiochemistry. Specific radionuclides that are most likely to be detected and their detection limits are listed in Tables B-1 and B-2. 


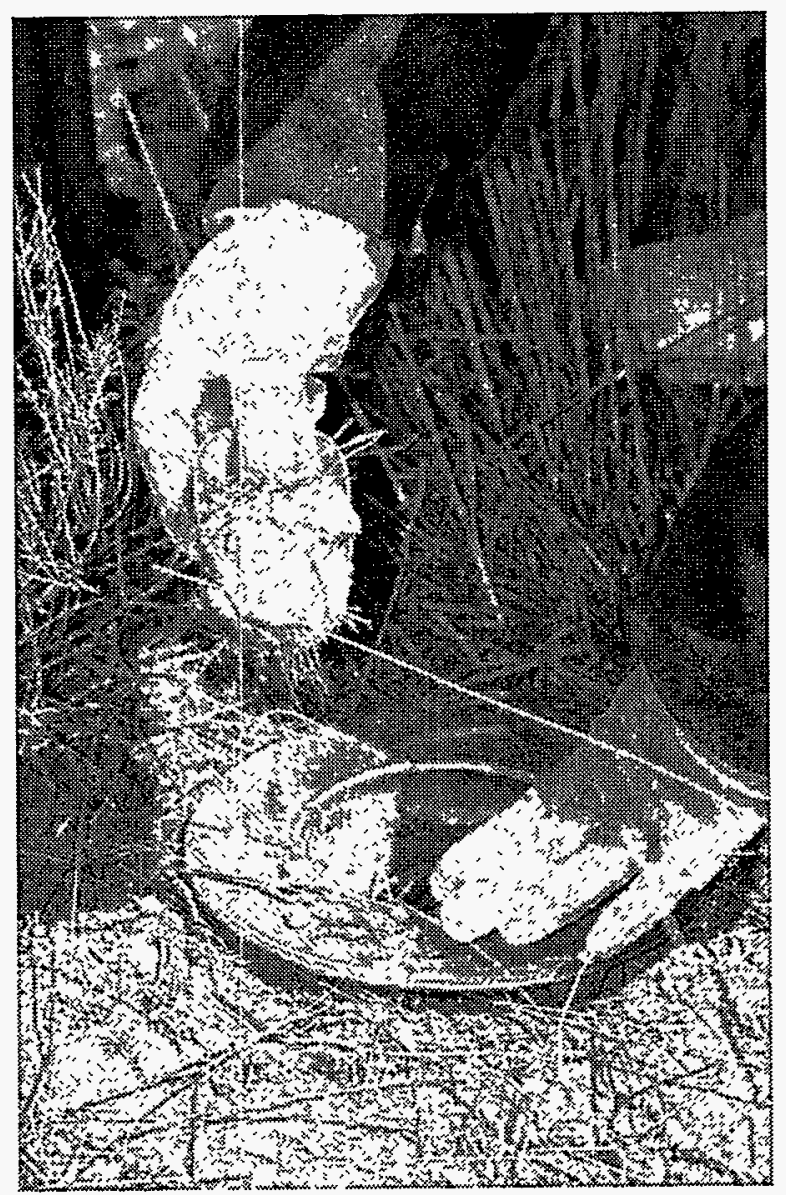

Figure 34. Soil sample collection (photo number 95-309-1-10).

\subsubsection{Radioactive Waste Management Complex}

Surface and near-surface soils at the RWMC have become contaminated as a result of the past flooding of open pits, waste handling, and intruding biota. Of particular concern is the presence of $\mathrm{Pu}-239,-240$ and Am-241 deposited in surface soils in and outside of the northeast corner of the SDA during flooding events. ${ }^{7}$ Wind, water, and biota can transport contaminated soil particulates outside of the RWMC boundaries.

The 1983 MAR provides much of the basis for the current surface soil sampling design. ${ }^{11}$ The MAR recommendations were implemented in 1984. The major design modification implemented from the 1983 MAR was to initiate sampling at randomly selected sampling locations in five permanent plots. These plots represent the five major areas of the RWMC, as categorized according to the types of waste buried, current operational activities, and past flooding events. Those major areas are the active areas, Pad A, inactive areas, previously flooded areas, and TSA (see Figure 35).

Although the original sampling areas defined in the 1983 MAR remained consistent, significant changes to the soil sampling activity were recommended by the 1988 MAR committee. ${ }^{12}$ The major proposed revision was to eliminate routine soil sampling and to replace it with special studies on an as-needed basis. The rationale for this recommendation was twofold: (a) the number of samples collected are probably insufficient for valid data interpretation, and (b) the addition of new soil cover during recontouring of the SDA in 1986 invalidates comparison with past data. 


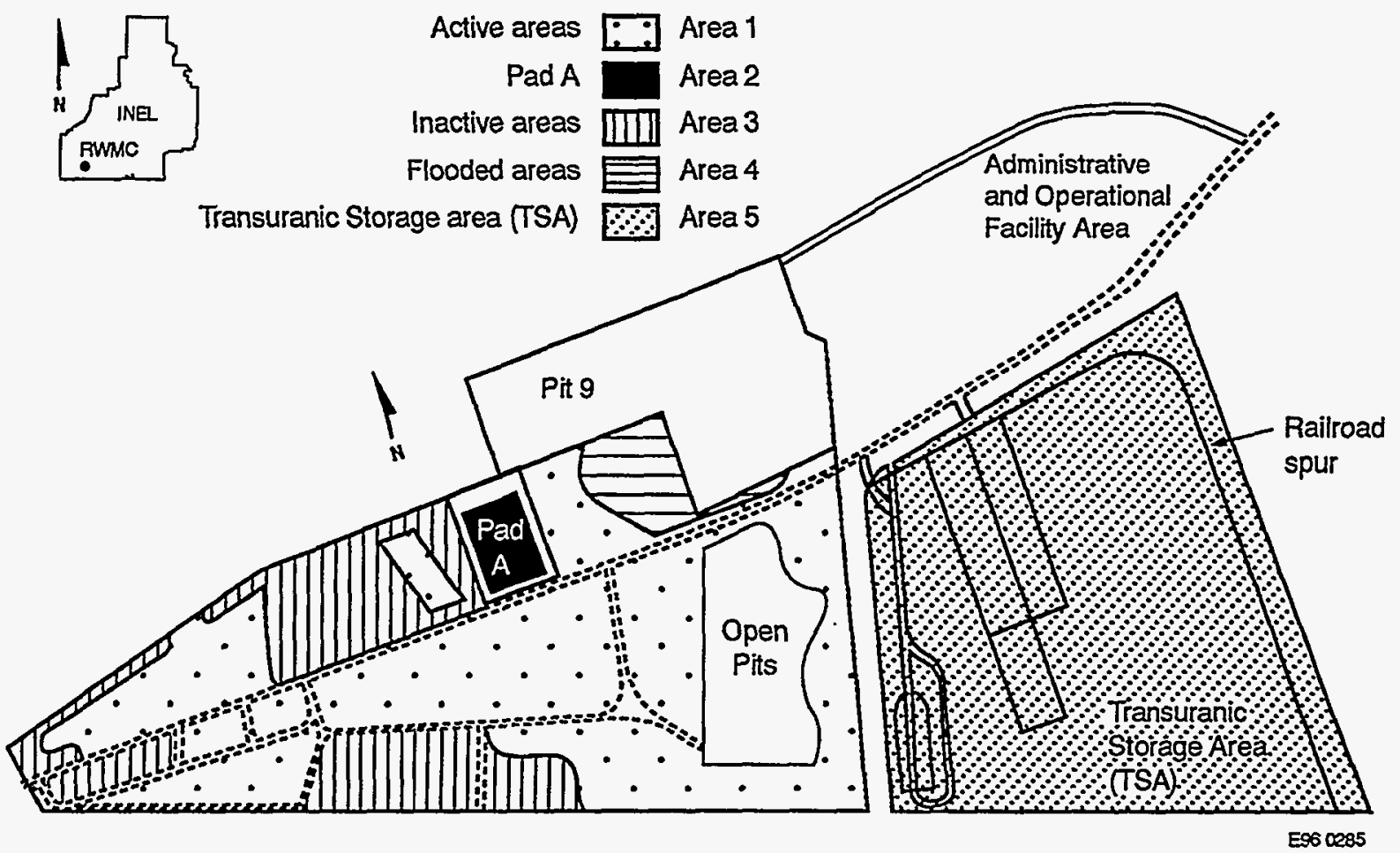

Figure 35. Five major areas of the RWMC used for vegetation, mammal, and soil collection.

RESP began collecting sample sets for data on the new soil cover on a triennial basis to establish a baseline. The collection effort began in 1991 at SDA and in 1992 at SWEPP. While additional soil is still being added to the SDA, RESP will continue to sample every three years to re-establish a baseline for SDA soil concentrations.

A second sample set for TSA was collected during 1995. The only gamma-emitting radionuclide detected in the TSA soils was Cs-137. The maximum concentration for Cs-137 was $9.9 \pm 0.7 \mathrm{E}-7$ $\mu \mathrm{Ci} / \mathrm{g}$ and was collected from location 1 (see Figure 36). This concentration is consistent with those found in disturbed surface soils across the INEL. Concentrations at these levels are attributable to fallout and are not a result of INEL operations.

Results of analyses for specific alpha- and beta-emitting nuclides are shown in Table 4. Table 4 shows only those concentrations considered above the level of detection. As shown in Table 4, the maximum concentration for Sr-90 was $6.7 \pm 0.7 \mathrm{E}-7 \mu \mathrm{Ci} / \mathrm{g}$ which was detected at the $\mathrm{T}-12 \mathrm{road}$. The $\mathrm{T}-12$ road functions as the control location for TSA (see Figure 32). Pu-239, -240 and Am-241 were found in TSA soils with a maximum concentration of $2.7 \pm 0.5 \mathrm{E}-8 \mu \mathrm{Ci} / \mathrm{g}$ for $\mathrm{Pu}-239,-240$ at location 11 (see Figure 36) and $3.4 \pm 0.6 \mathrm{E}-8 \mu \mathrm{Ci} / \mathrm{g}$ for Am-241 at location 13. These concentrations are considerably less than the Environmental Concentration Guidelines (see Table 4) for soil that corresponds to a 50-year dose commitment of $100 \mathrm{mrem} / \mathrm{yr}$ to a homesteader (see Appendix D). These concentrations are comparable to historical data and were at or near the detection limits.

\subsubsection{Waste Experimental Reduction Facility}

Routine soil samples are collected from the 11 WERF locations shown in Figure 37. Control samples for WERF are collected near the Main Gate, Building 603 (see Figure 11). No samples were collected during 1995. The next sample collection is scheduled for the summer of 1996. 


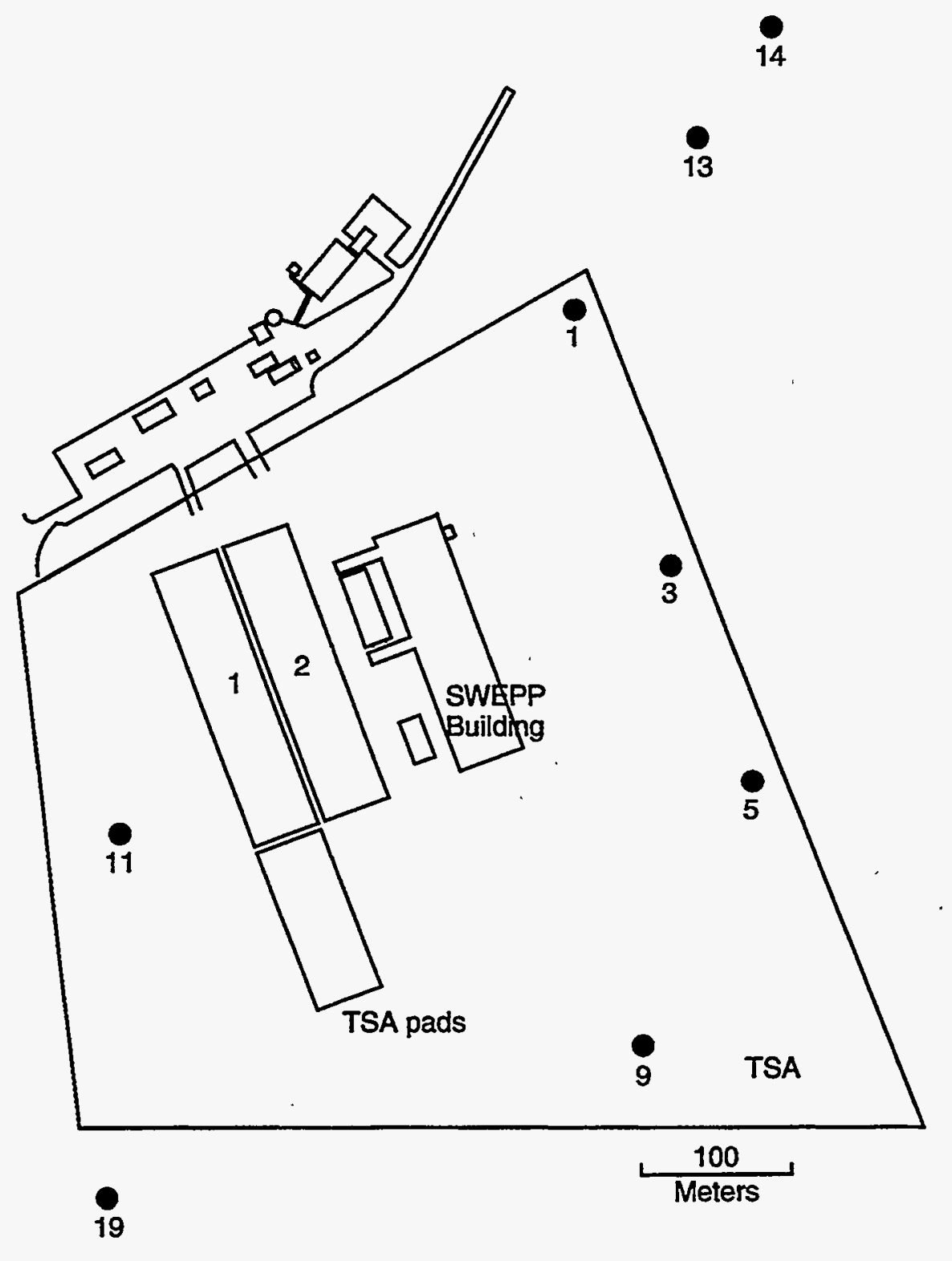

20

M92 0242

Figure 36. General TSA soil locations. 


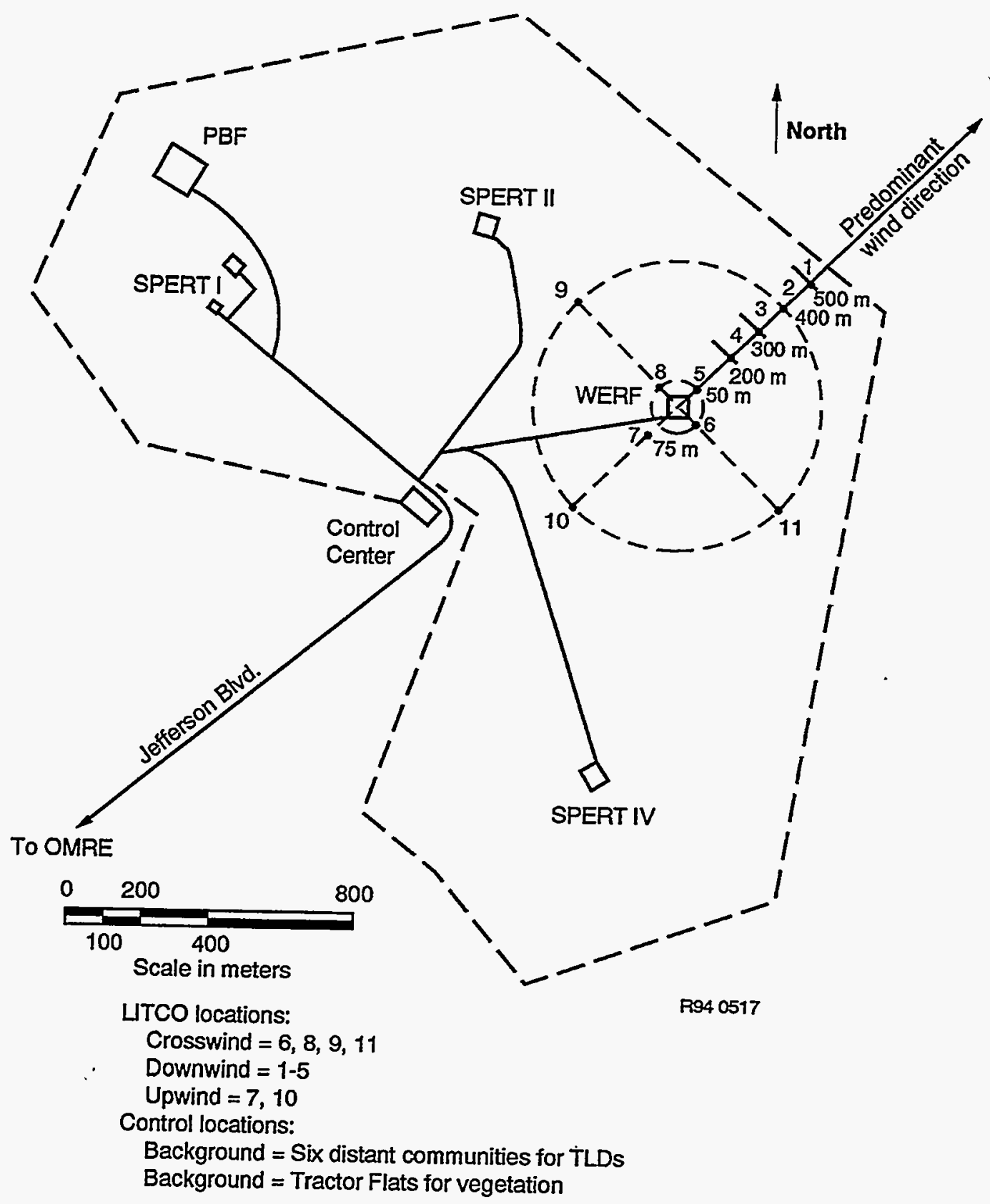

Figure 37. WERF TLD, soil, and vegetation locations. 
Table 4. Specific radionuclide results for TSA soils.

\begin{tabular}{|c|c|c|c|c|}
\hline \multirow[t]{2}{*}{ Location } & \multicolumn{4}{|c|}{ Concentration $(\mu \mathrm{Cj} / \mathrm{g})$} \\
\hline & Sr-90 & $\mathrm{Pu}-238^{\mathrm{a}}$ & Pu-239, -240 & Am-241 \\
\hline 1 & $5.6 \pm 0.6 \mathrm{E}-7$ & & & $3.4 \pm 0.8 \mathrm{E}-8$ \\
\hline 3 & $4.4 \pm 0.5 \mathrm{E}-7$ & & $1.8 \pm 0.5 \mathrm{E}-8$ & \\
\hline 5 & $3.6 \pm 0.4 \mathrm{E}-7$ & & $9.0 \pm 2.0 \mathrm{E}-9$ & \\
\hline 9 & $3.1 \pm 0.4 \mathrm{E}-7$ & & & \\
\hline 11 & $9.0 \pm 3.0 \mathrm{E}-8$ & & $2.7 \pm 0.5 \mathrm{E}-8$ & \\
\hline $11 \mathrm{R} 2$ & $3.2 \pm 0.6 \mathrm{E}-7$ & & & \\
\hline 13 & $4.7 \pm 0.5 \mathrm{E}-7$ & & $2.2 \pm 0.4 \mathrm{E}-8$ & $3.4 \pm 0.6 \mathrm{E}-8$ \\
\hline 19 & $4.4 \pm 0.5 \mathrm{E}-7$ & & & \\
\hline Control & $6.7 \pm 0.7 \mathrm{E}-7$ & & $2.5 \pm 0.7 \mathrm{E}-8$ & \\
\hline$E C G^{b}$ & $6.0 \mathrm{E}-6$ & & $8.0 \mathrm{E}-5$ & $4.0 \mathrm{E}-5$ \\
\hline $\begin{array}{l}\% \text { of ECG for } \\
\text { maximum } \\
\text { concentration }\end{array}$ & 11.2 & & .03 & .09 \\
\hline $\begin{array}{l}\text { a. Analyses for } \\
\text { b. ECG = Envir } \\
\text { ment of } 100 \text { mrer } \\
\text { assumes uniform }\end{array}$ & $\begin{array}{l}\text { how no positive } \\
\text { Concentration } \\
\text { homesteader be } \\
\text { lation of an area }\end{array}$ & $\begin{array}{l}\text { is greater th } \\
\text {. These co } \\
\text { n the first y } \\
\text { for subsist }\end{array}$ & $\begin{array}{l}\text { s the analytical } u \\
\text { ns correspond to } \\
\text { release of the fac } \\
\text { ing. }\end{array}$ & $\begin{array}{l}\text { nty. } \\
\text { ear dose commit- } \\
\text { his concentration }\end{array}$ \\
\hline
\end{tabular}

\subsection{Biotic Surveillance}

Plants and animals present potential pathways for radionuclides to migrate away from facilities at which radioactive contaminated wastes are stored. Several studies, that were previously performed by RESL and are currently done by the Environmental Science and Research Foundation, indicate that small burrowing mammals, such as deer mice, transport radionuclides. ${ }^{13}$ Uptake of radionuclides by vegetation at the RWMC has also been documented by RESL. ${ }^{14}$

Routine biotic monitoring was not conducted prior to 1983 . Some preliminary data on radionuclide concentrations in deer mice and crested wheatgrass were collected by EG\&G Idaho during fiscal year 1982. Visual inspections of biotic activity began in April 1983.

A detailed long-range plan for biotic monitoring, including procedures for routine monitoring, was completed in the fall of $1983 .{ }^{15}$ The sampling design involved sampling biota at the five major areas designated for soil sampling (see Figure 35).

The specific objectives of routine biotic surveillance are to (a) determine if biota are transporting radionuclides from buried waste or contaminated soil, (b) identify biotic conditions which may 
compromise waste confinement at waste storage and disposal facilities, and (c) detect and report significant trends in radionuclide concentrations in biotic samples.

\subsubsection{Vegetation}

Three subsamples are collected from each of the sampling locations and combined into one composite sample. The method of collection and the species alternates each year. Crested wheatgrass is collected in odd-numbered years and is clipped at ground level within a $1 \times 1-\mathrm{m}(1.1 \times 1.1 \mathrm{yd})$ frame. Russian thistle is collected in even-numbered years, and the entire plant is pulled up within a $1 \times 1-\mathrm{m}(1.1 \times 1.1 \mathrm{yd})$ frame (see Figure 38$)$. Either rabbitbrush or sagebrush is collected in odd-numbered years by clipping $20 \%$ of the branches from the designated plants. Thus, the same plant can be sampled biennially.

The samples are oven-dried, milled, and weighed before they are submitted to the RML for gamma spectrometry analyses. Based on gamma analyses, selected samples are submitted to the Radiation and Environmental Measurement Systems for specific alpha and beta analyses.

Prior to 1990, RESP performed specific radiochemical analysis only if gamma spectrometry indicated the presence of Am-241. If Am-241 was not detected in any sample, then one sample from the previously flooded area of SDA was submitted for this analysis. In 1990, RESP concluded that this practice restricted the accumulation of an adequate baseline of such data, against which comparisons could be made in future years. The program subsequently began submitting at least one sample from each of the five major areas for radiochemical analysis annually.

RWMC. Crested wheatgrass was collected in 1995 from four of the five major areas of the RWMC (see Figure 35). The TSA Pad was not sampled due to construction on the Pad. No man-made, gamma activity was detected in any of the samples collected.

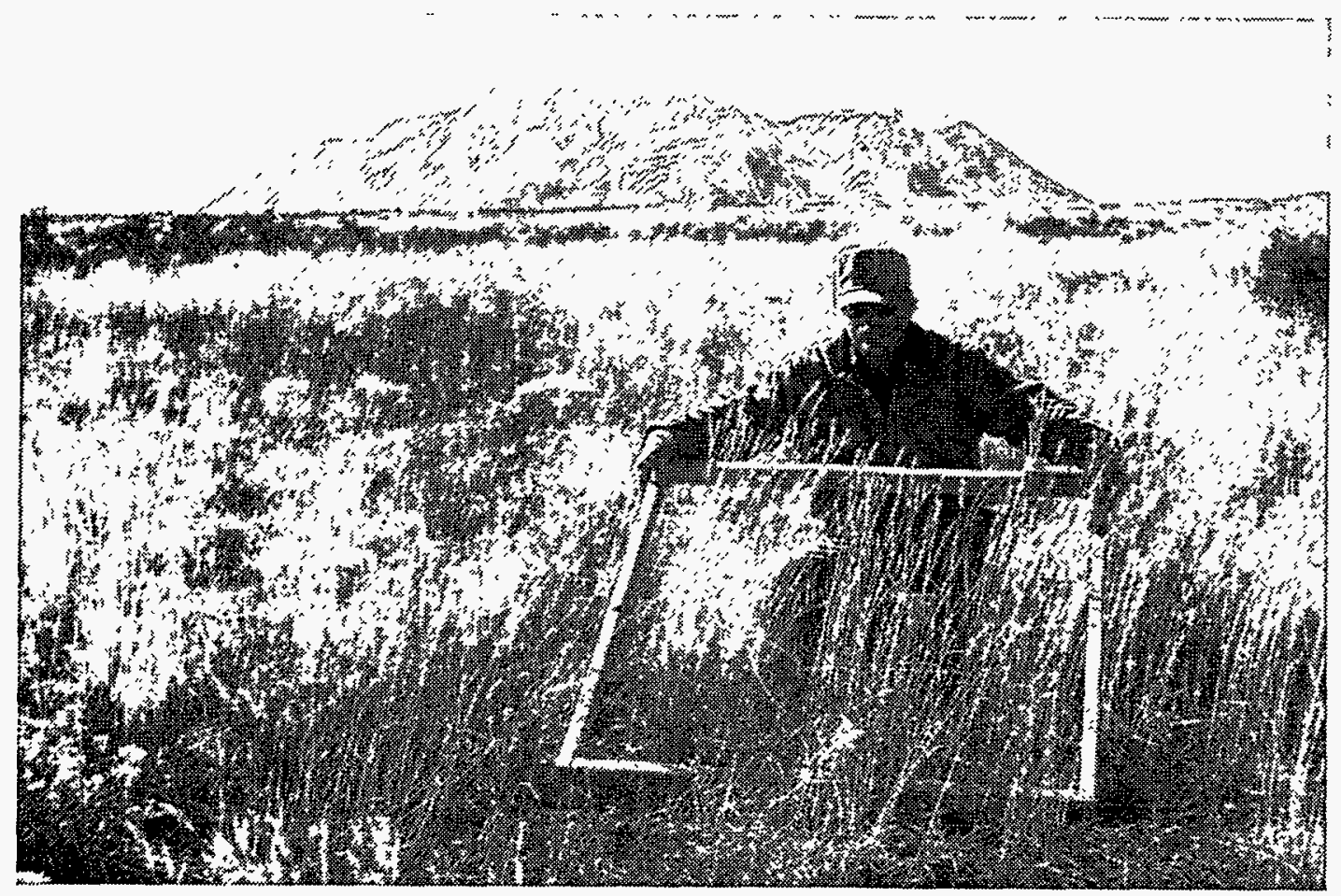

Figure 38. Collecting vegetation at the RWMC (photo number DP960016). 
Control samples were collected near Frenchman's cabin, located approximately $11 \mathrm{~km}$ (6.8 mi) south of the SDA at the base of the Big Southern Butte. Samples selected for specific alpha- and beta-emitting radionuclides were submitted for analysis. $\mathrm{Pu}-239,-240$ were detected in samples collected from areas one and three (see Figure 35). The maximum concentration was $3.8 \pm 0.8 \mathrm{E}-9 \mu \mathrm{Ci} / \mathrm{g}$ at area three. Am-241 was also detected at areas one and three with the maximum concentration of $1.8 \pm 0.3 \mathrm{E}-8 \mu \mathrm{Ci} / \mathrm{g}$ occurring in area one. These concentrations fell within RESL's range of results for vegetation samples collected at the RWMC. ${ }^{14}$ These activities probably result from deposition as opposed to uptake in the vegetation. Sr-90 results were invalidated due to evidence of cross-contamination during analysis.

Perennials were also scheduled to be collected during 1995. However, due to increased operational activity and the disturbance of the ground cover in and around the RWMC, representative samples could not be obtained; thus, no samples were collected during 1995.

WERF. Vegetation collection at WERF began in 1984 and is performed every three years. The next sagebrush samples are scheduled to be collected in 1996 (see Figure 37).

\subsubsection{Radioactivity in Small Mammals}

RESP has routinely sampled small mammals at the RWMC to evaluate confinement integrity of buried waste. The species for collection, as well as the method of collection, alternates each year. Deer mice are collected in odd-numbered years, and ground squirrels are collected in even-numbered years. The population of the small mammals was not sufficient for collecting a representative sample in each of the five major sample areas in accordance with the current procedure. The procedures for sampling small mammals at the RWMC will be evaluated during 1996. The sampling frequency for RWMC small mammals could be based on small mammal activity rather than collecting samples on a routine basis.

\subsubsection{Soil Excavated by Small Mammals}

Samples of soil excavated by burrowing animals was scheduled to be collected during 1995 at the RWMC from each of the five major areas (see Figure 35). No samples were collected due to lack of small mammal burrows.

\subsection{Penetrating Radiation}

TLDs are used to measure cumulative exposures to ambient ionizing radiation. Figure 39 shows the placement of a TLD.

TLDs are sensitive to beta energies greater than $200 \mathrm{KeV}$ and to gamma energies greater than $10 \mathrm{KeV}$. The TLD packets contain five lithium fluoride chips and are placed about $1 \mathrm{~m}$ (1.1 yd) above the ground at specified locations. The five chips provide replicate measurements at each location. The TLD packets are replaced in May and November of each year. The sampling periods for 1995 were from November 1994 to May 1995 and from May to November 1995.

The specific objectives of penetrating radiation monitoring are to (a) characterize direct radiation levels at specific points of interest at INEL Waste Management Facilities, and (b) detect and report significant trends in measured levels of penetrating radiation.

\subsubsection{Trend Analysis}

TLD cumulative 6-month exposure data for 1986 through 1995 from SDA, TSA, and WERF are presented in Figure 40. Data from the distant communities are excluded from the trend chart. To 


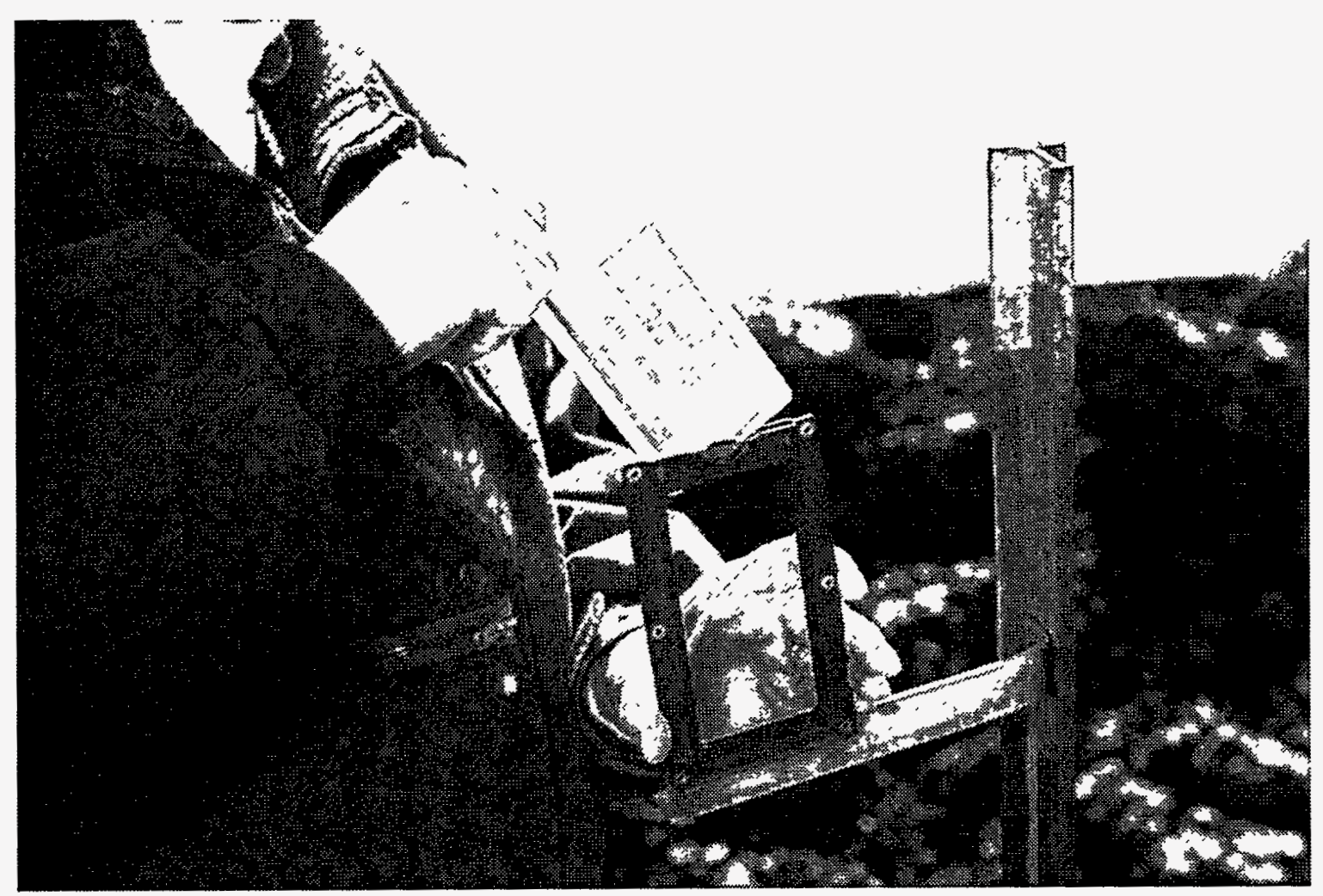

Figure 39. Placement of a TLD at a facility perimeter station (photo number DP960019).

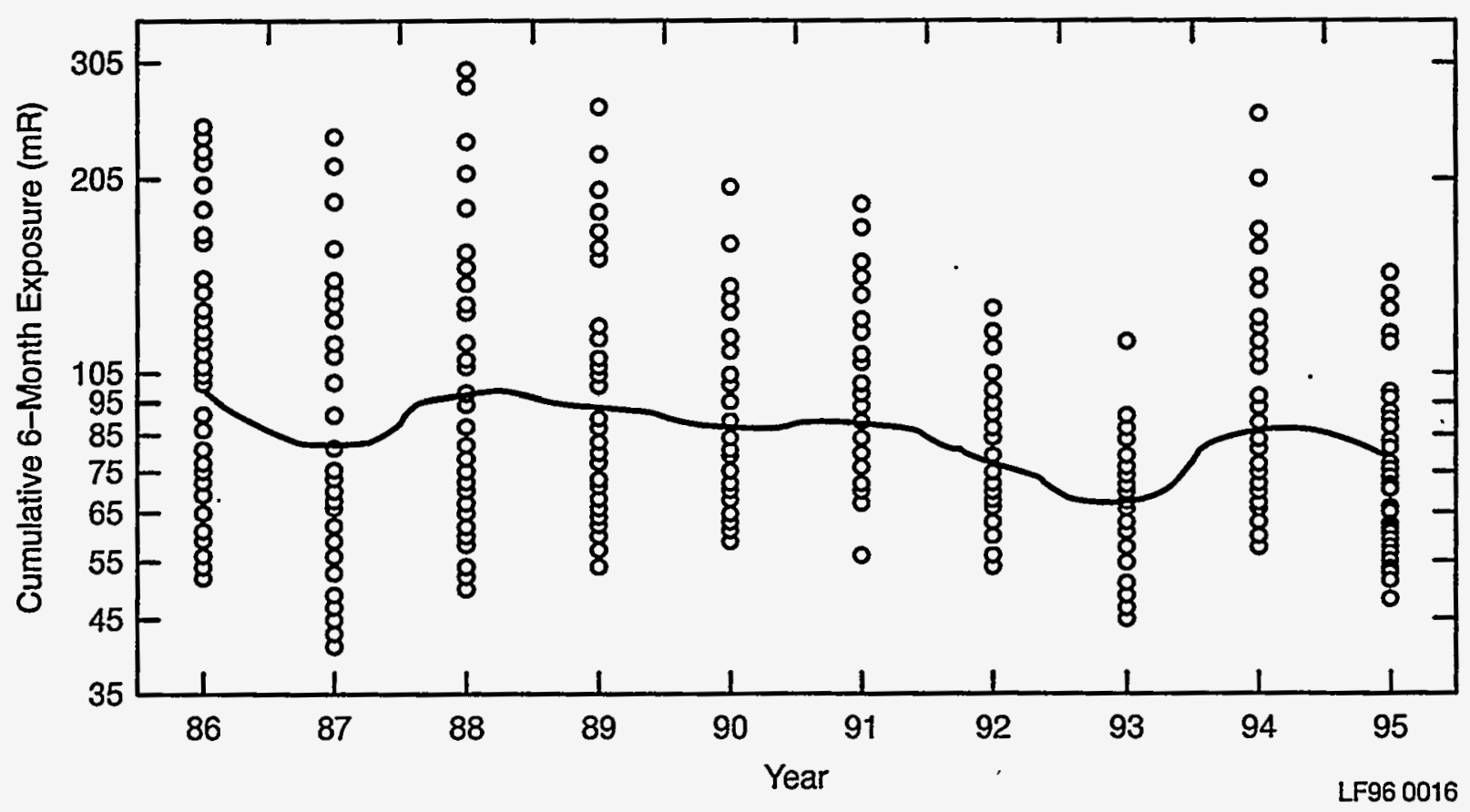

Figure 40. TLD exposure data from SDA, TSA, and WERF using negative exponential smoothing. 
indicate the general trend in values over time, data in the graph were smoothed using negative exponential smoothing. The data are plotted on a logarithmic scale to give a clearer picture of the trends. Although there has been some cycling of values, the general trend in the graph indicates a gradual decline in TLD exposures over time.

\subsubsection{Statistical Comparisons by Facility}

The summary statistics (e.g., means, medians, maximum, and minimum values) for 1995 TLD exposures are given in Table 5. Additionally, box and whisker plots of the TLD exposure by facility (including the distant communities) are provided for both 1994 and 1995 (Figures 41 and 42, respectively). The 1994 TLD exposures are included to provide an indication of short term changes in levels.

The median 1995 exposure value for the TSA facility grouping increased from the median exposure value calculated for 1994, while the median exposures for the distant communities, and the SDA and WERF facilities decreased from 1994.

\subsubsection{Seasonal Change}

The box and whisker plot of the 1995 TLD exposure data by season (including all facilities and the distant communities) indicates that the median exposure value for the fall measurement period ending in November of 1995 was significantly greater than that from the spring measurement period ending in May of 1995 (Figure 43). This difference (tested using the Kruskal-Wallis test) was found to be statistically significant (at the .05 level). The 1994 box and whisker plot of TLD exposure by season is provided as Figure 44, for comparison purposes.

Table 5. Summary statistics for 1995 TLD 6-month exposures (all concentration values are mR).

\begin{tabular}{lcccccc}
\hline Facility & Season & N & Mean & Median & Minimum & Maximum \\
\hline SDA & Spring & 19 & 83.1 & 77.0 & 60 & 140 \\
& Fall & 18 & 121.1 & 114.5 & 58 & 256 \\
TSA & Spring & 12 & 74.3 & 71.5 & 66 & 97 \\
& Fall & 11 & 88.5 & 89.0 & 72 & 118 \\
WERF & Spring & 11 & 71.8 & 67.0 & 63 & 85 \\
& Fall & 11 & 68.1 & 66.0 & 58 & 81 \\
Distant & Spring & 7 & 64.6 & 63.0 & 60 & 71 \\
Communities & Fall & 6 & 61.2 & 61.0 & 56 & 70 \\
\hline
\end{tabular}




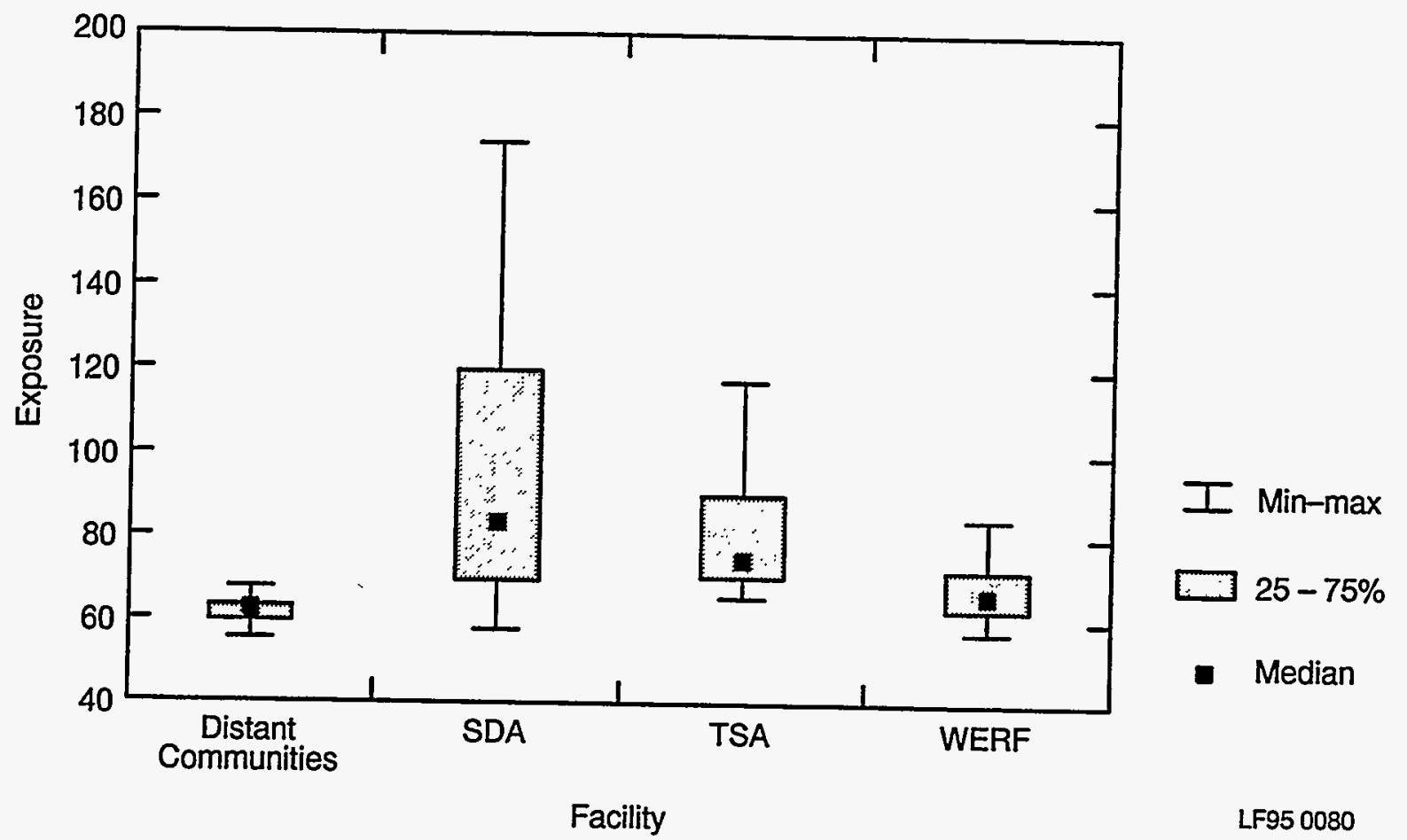

Figure 41 . 1994 box and whisker plots of the TLD exposure by facility.

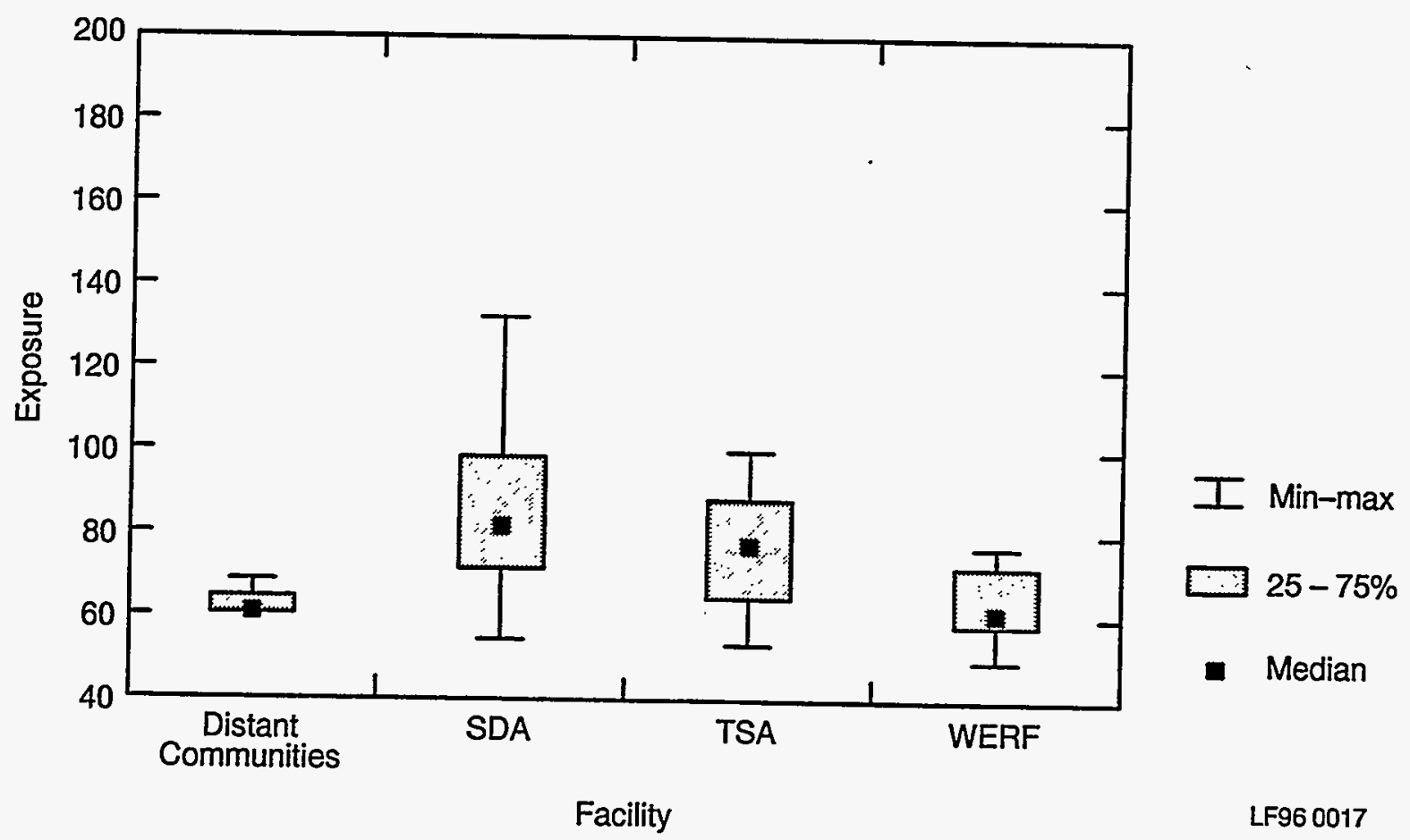

Figure 42. 1995 box and whisker plots of the TLD exposure by facility. 


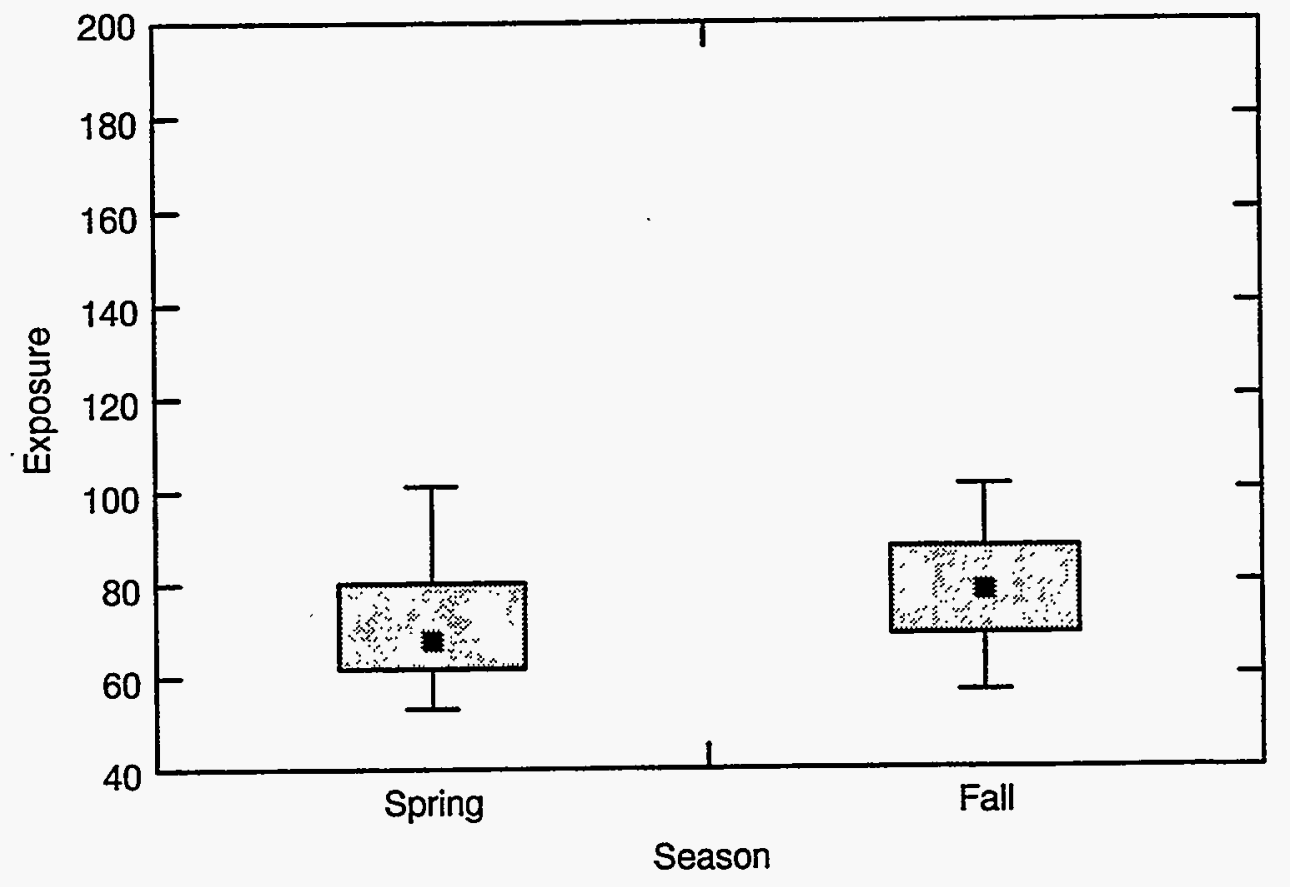

I Min-max

$25-75 \%$

- Median

LF96 0018

Figure 43. 1995 exposure trends for the spring and fall average TLD measurements.

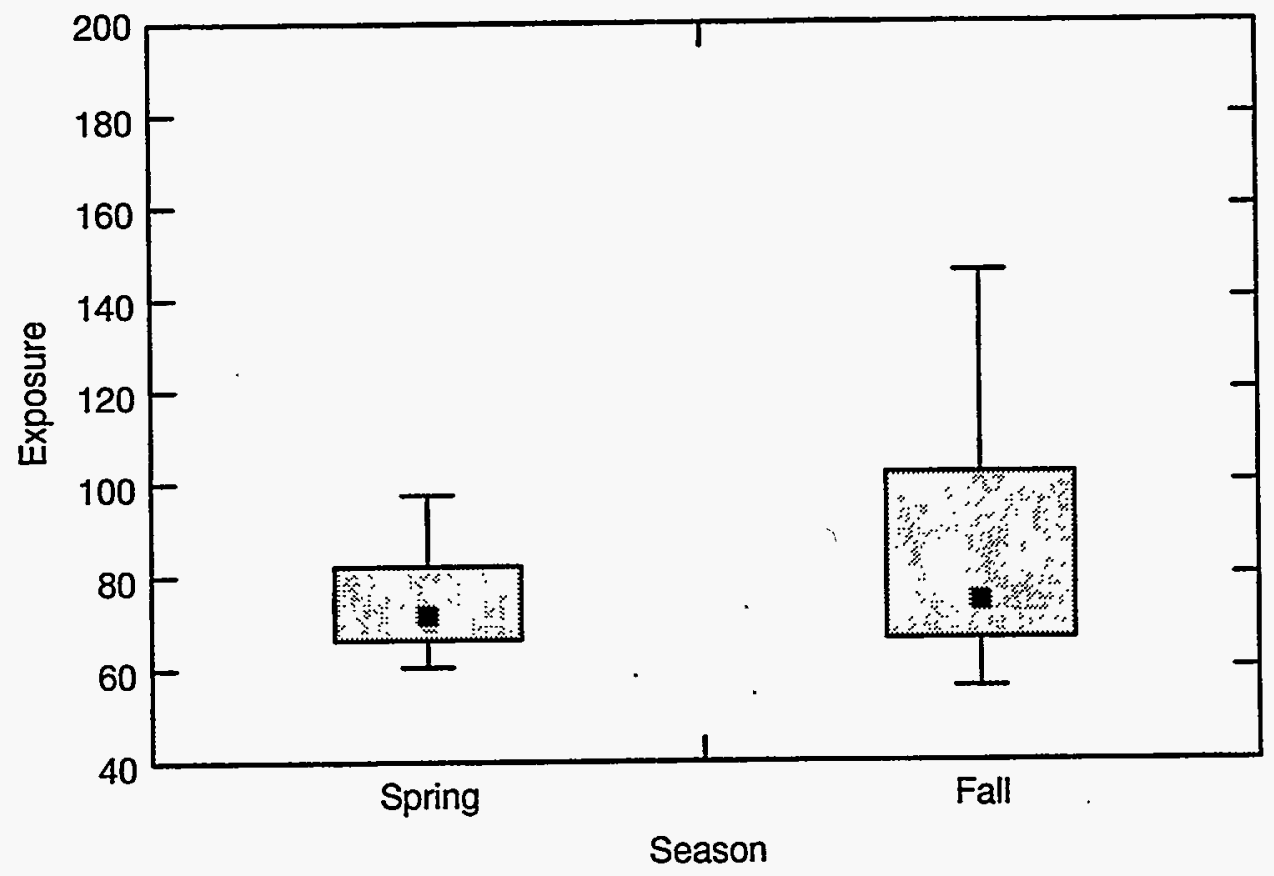

I Min-max

$25-75 \%$

- Median

LF95 0081

Figure 44. 1994 exposure trend for the spring and fall average TLD measurements. 


\subsubsection{Radioactive Waste Management Complex}

RESP placed TLD packets at five locations around the RWMC and at two locations on the TSA fence. TLD packets were placed at 24 other locations by SESP. (See Figure 45 for all locations.) The locations at Stations 1, 31, 33, and 35 were changed slightly in November 1988 and are now labeled 1B, 31B, 33B, and 35B. SESP locations 3A through 31A were moved in May 1988 because a new fence was installed, and the dike was raised around the SDA. Two additional locations, Stations 46 and 47, were added to the perimeter of the RWMC in May 1989, and thus, a total of 31 locations were monitored.

Background exposure results from penetrating radiation from natural terrestrial sources (rocks and soil), cosmic radiation, fallout from testing of nuclear weapons, and local industrial processes. The background exposures used in this report are exposure averages measured by TLDs in the seven Snake River Plain communities located outside the INEL boundary. Background exposures were measured at Aberdeen, Blackfoot, Craters of the Moon National Monument, Idaho Falls, Minidoka, Rexburg, and Roberts.

Station 33B showed the highest exposure in the first reporting period of 1995, and Station 35B showed the highest exposure during the second period of 1995 . However, 35B was missing during the first collection for 1995. These stations measure exposures associated with the active disposal pit and operational activities in that area. In addition, measured exposures at many stations in the proximity of the active pit have decreased during the second reporting period. This decrease is attributed to the additional soil placed over waste in the active disposal pit.

Figures 46 through 53 show the six-month exposures for the past 11 years as measured by TLDs along the following RWMC SDA borders: northwest, northeast, south, southwest, southeast, west, and east. Average distant-community background exposure is shown on each graph for comparison.

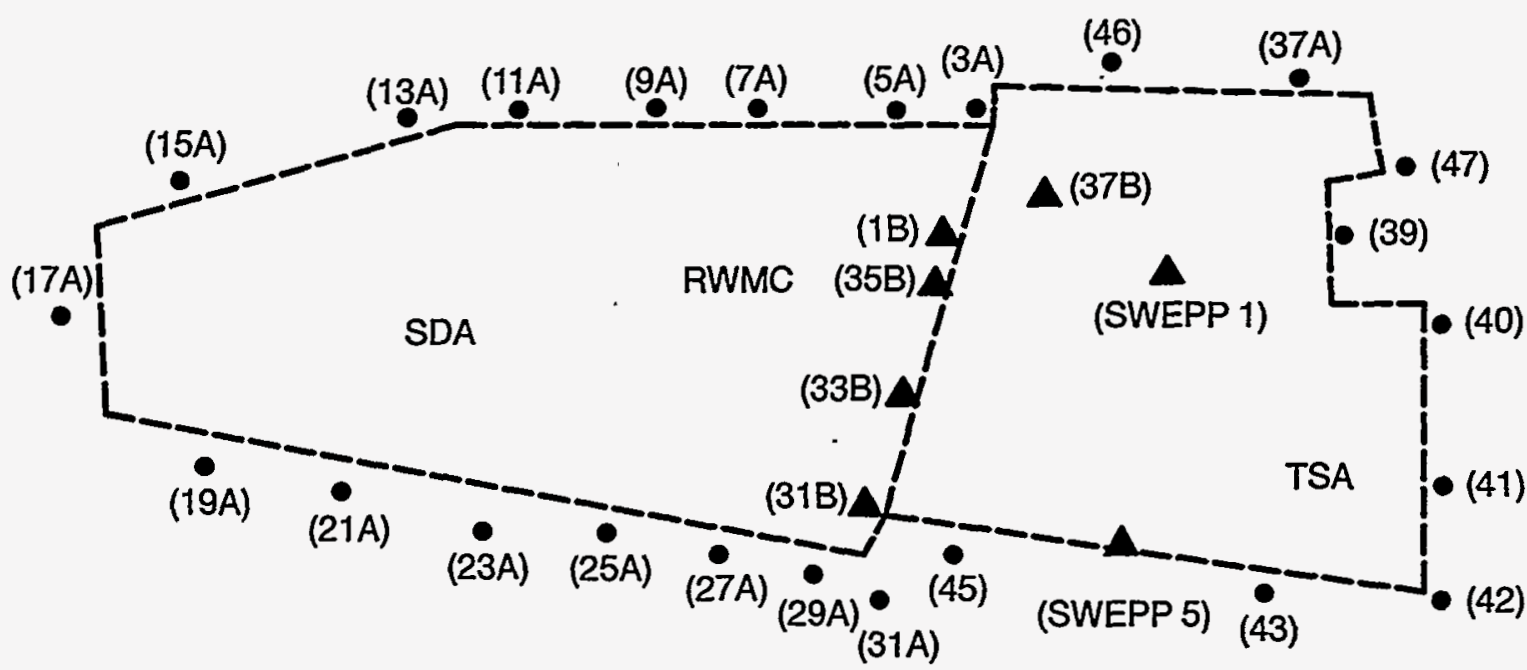

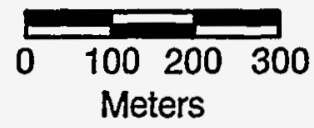

$(31 \mathrm{~A})$
- SESP TLD location

- RESP TLD location

Figure 45. RWMC TLD locations. 


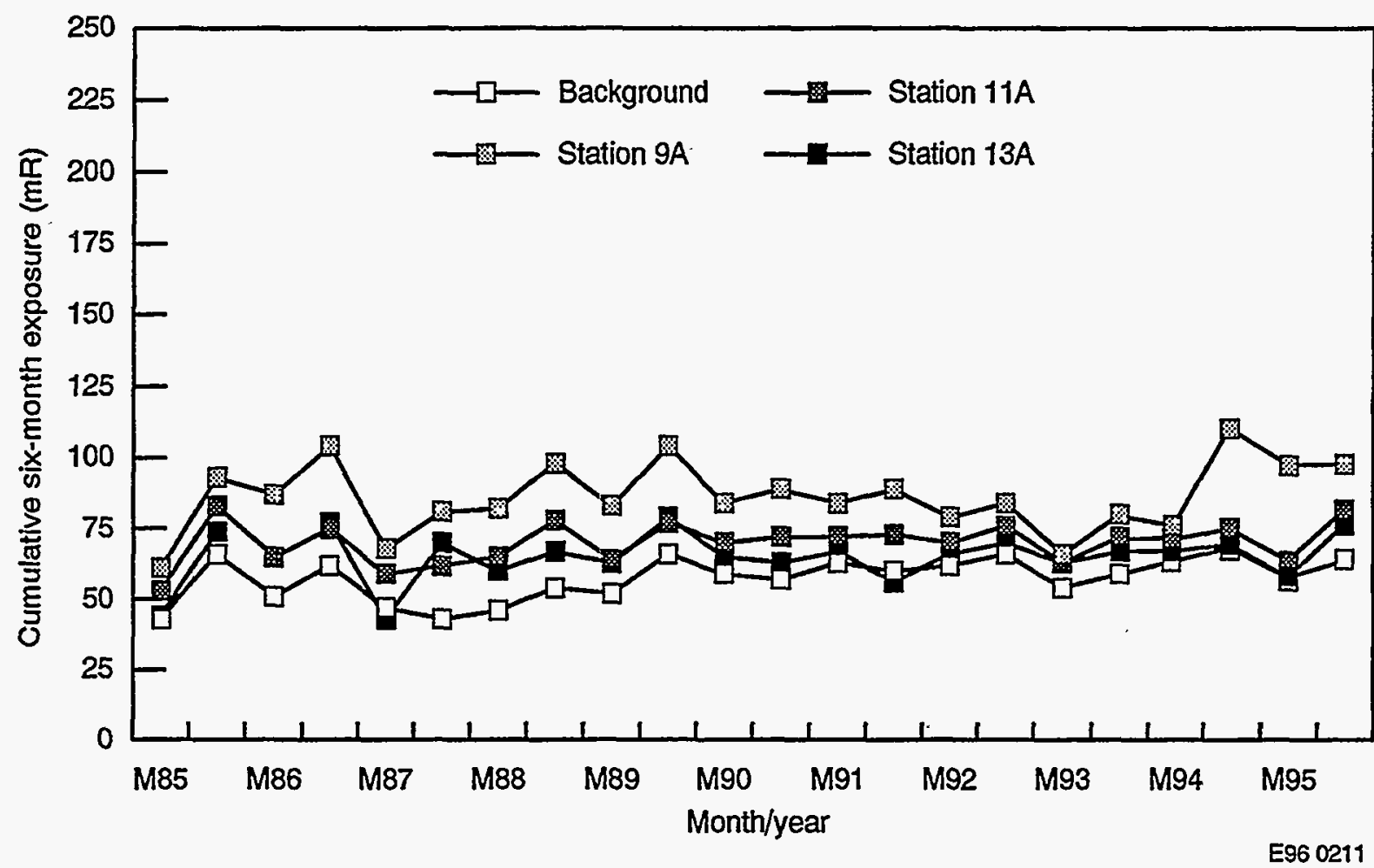

Figure 46. Six-month exposures measured by TLDs on the northwest border of the SDA.

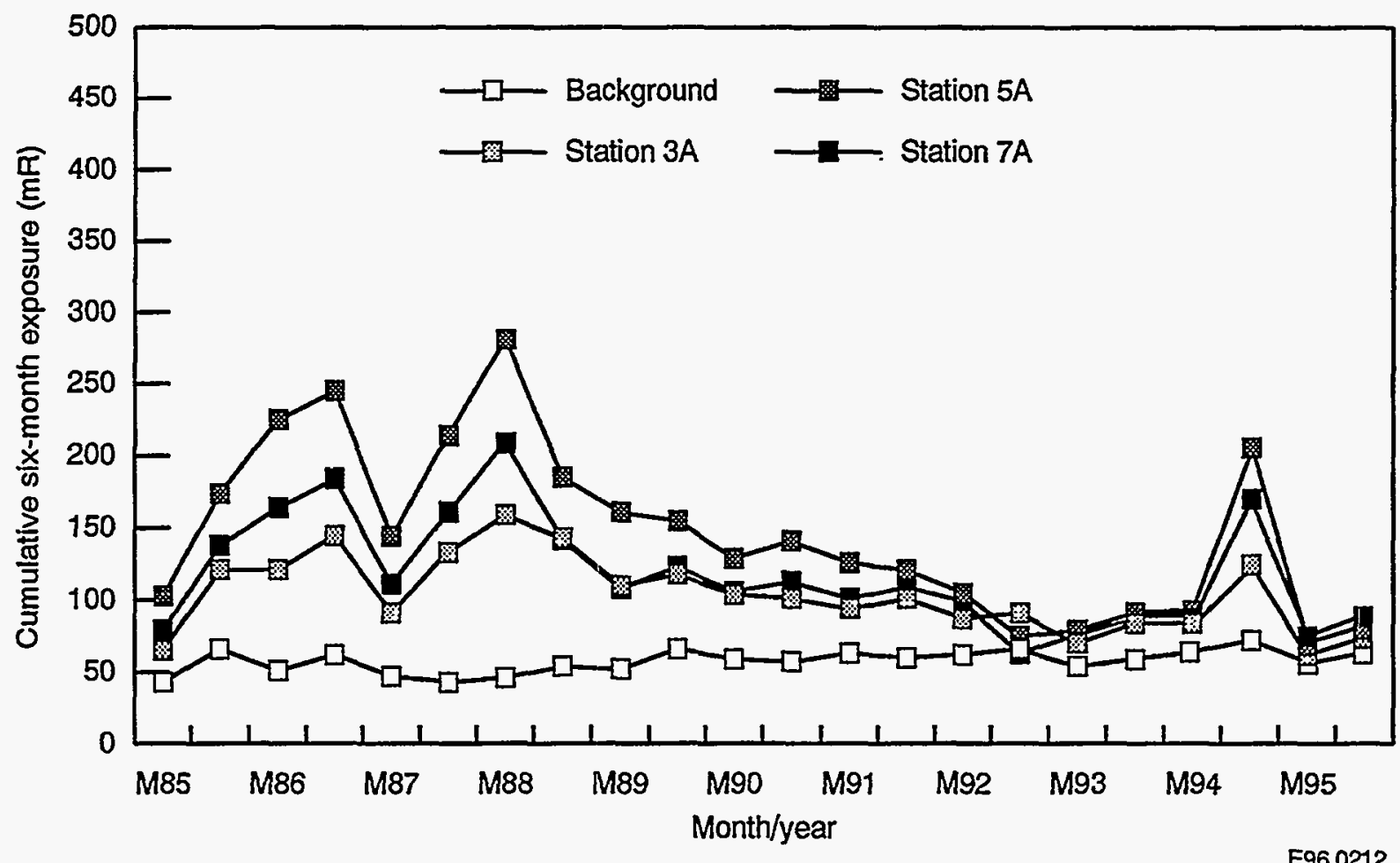

Figure 47. Six-month exposures measured by TLDs on the northeast border of the SDA. 


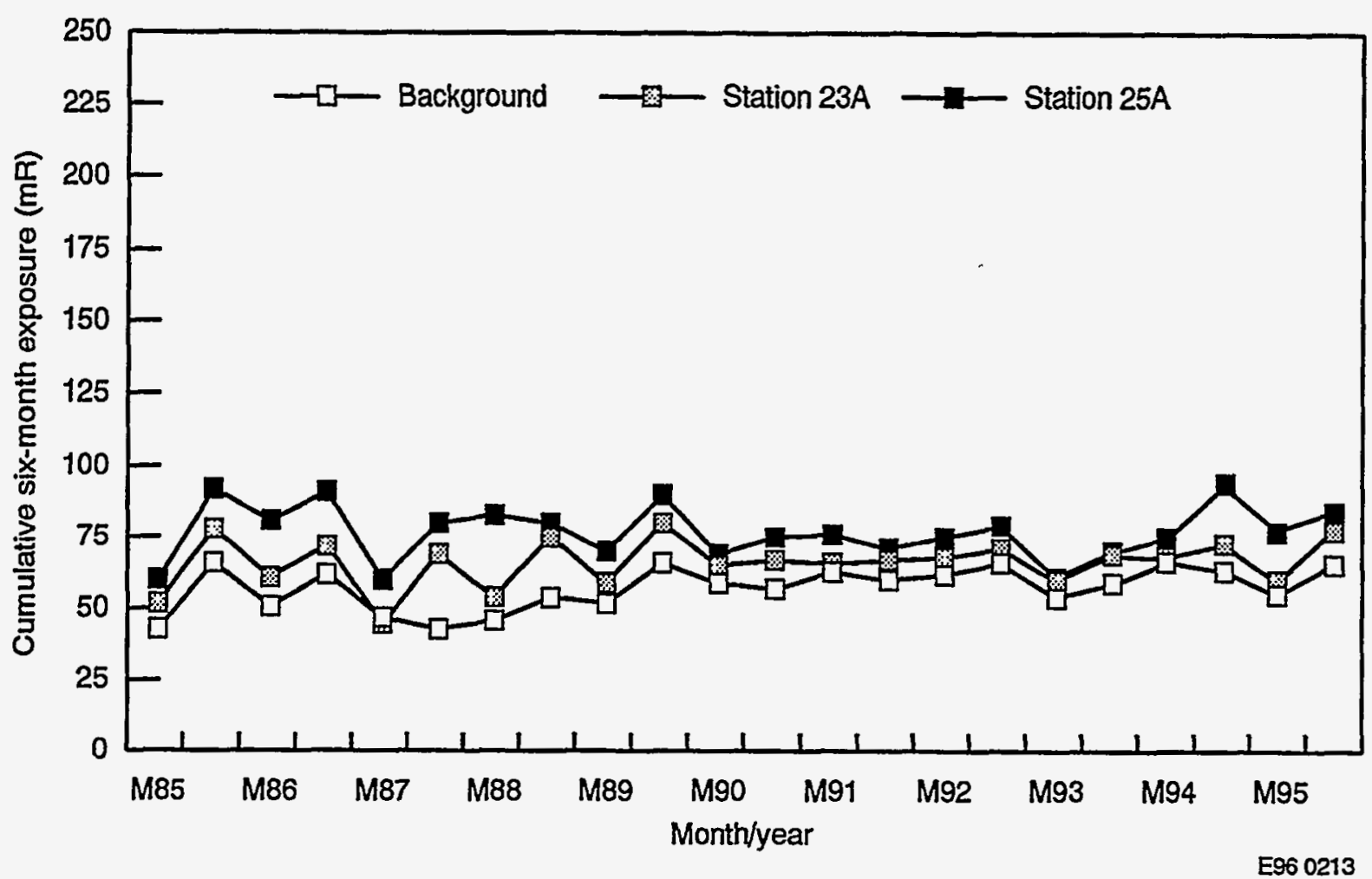

Figure 48. Six-month exposures measured by TLDs on the south border of the SDA.

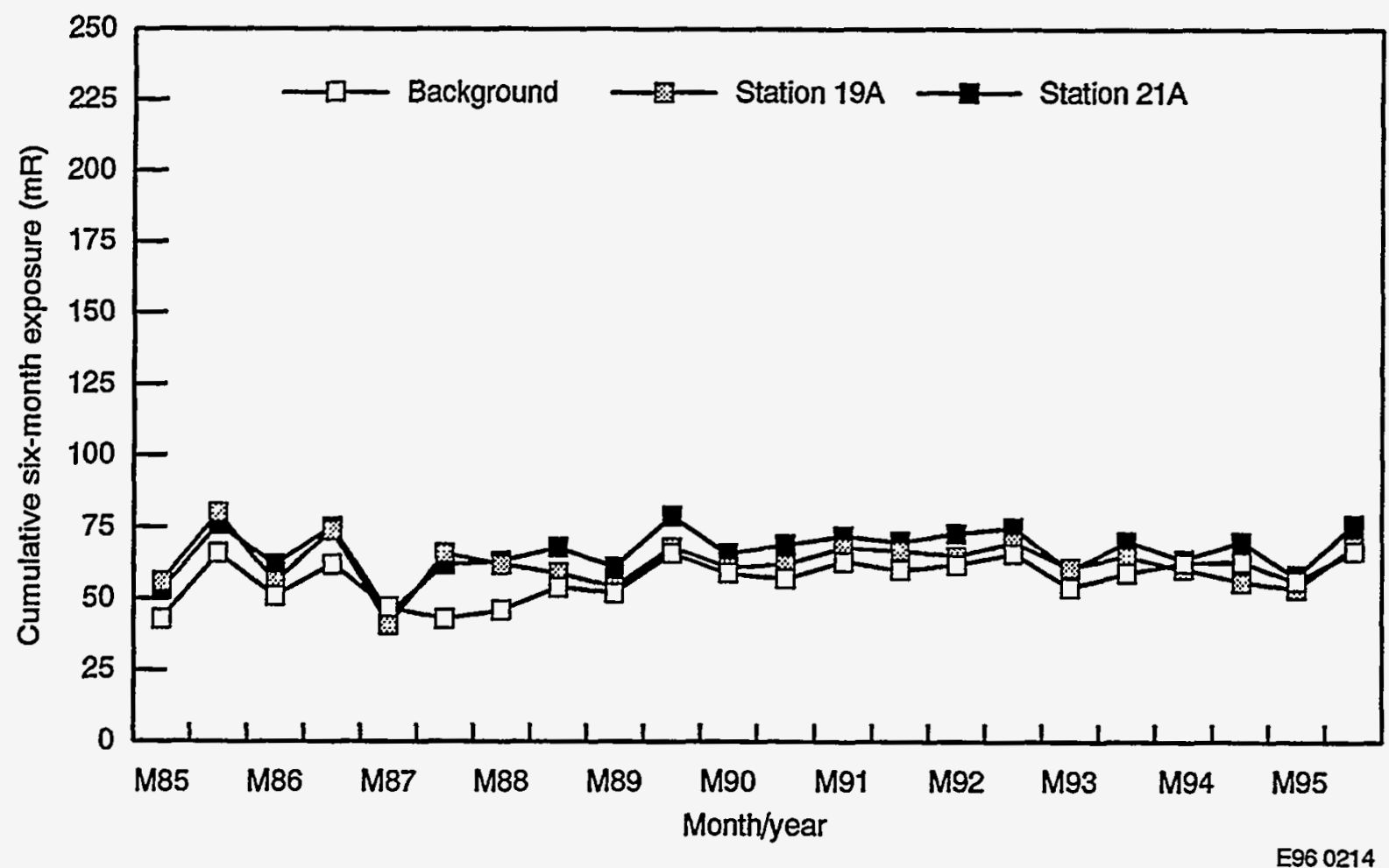

Figure 49. Six-month exposures measured by TLDs on the southwest border of the SDA. 


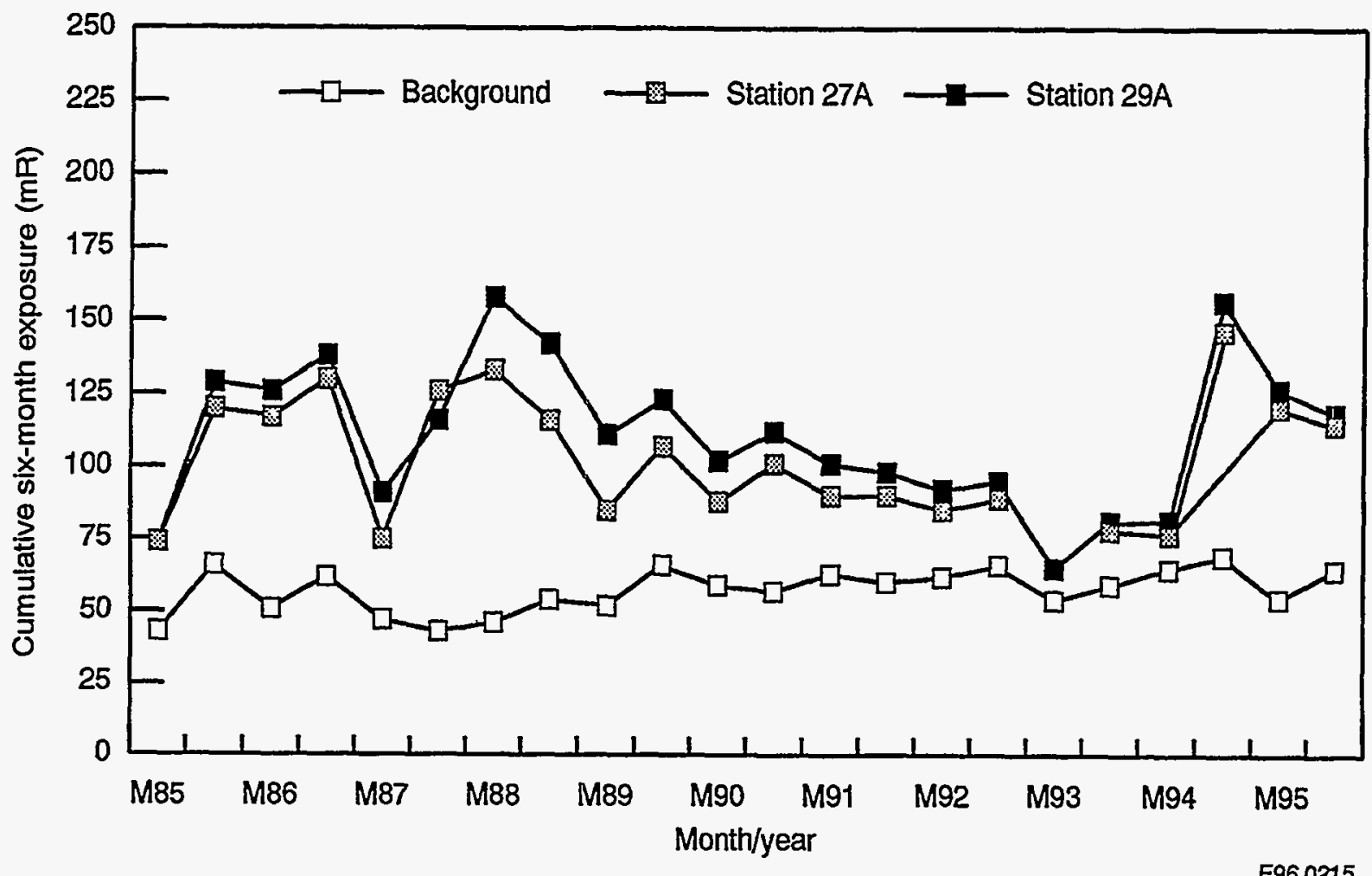

Figure 50. Six-month exposures measured by TLDs on the southeast border of the SDA.

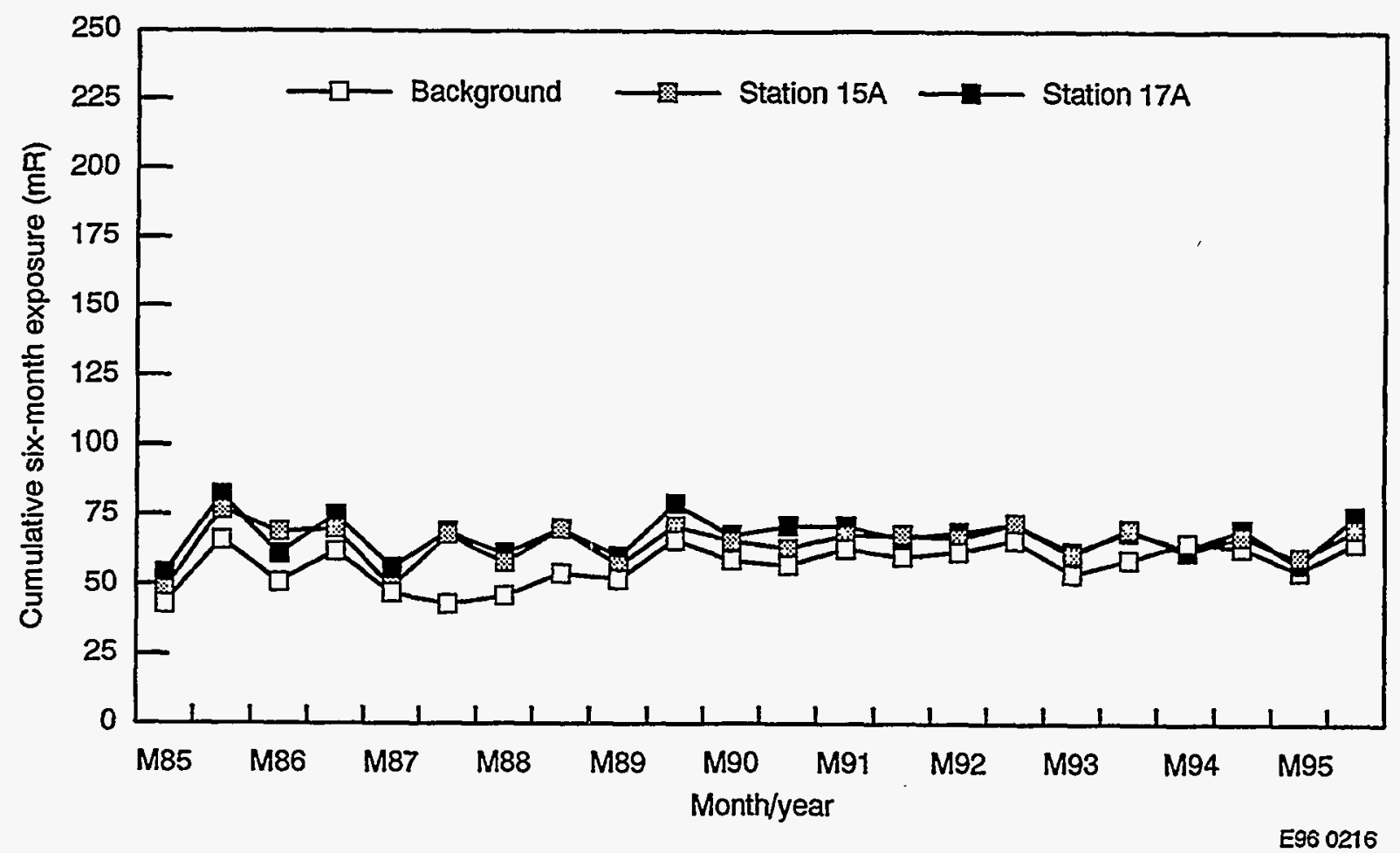

Figure 51. Six-month exposures measured by TLDs on the west border of the SDA. 


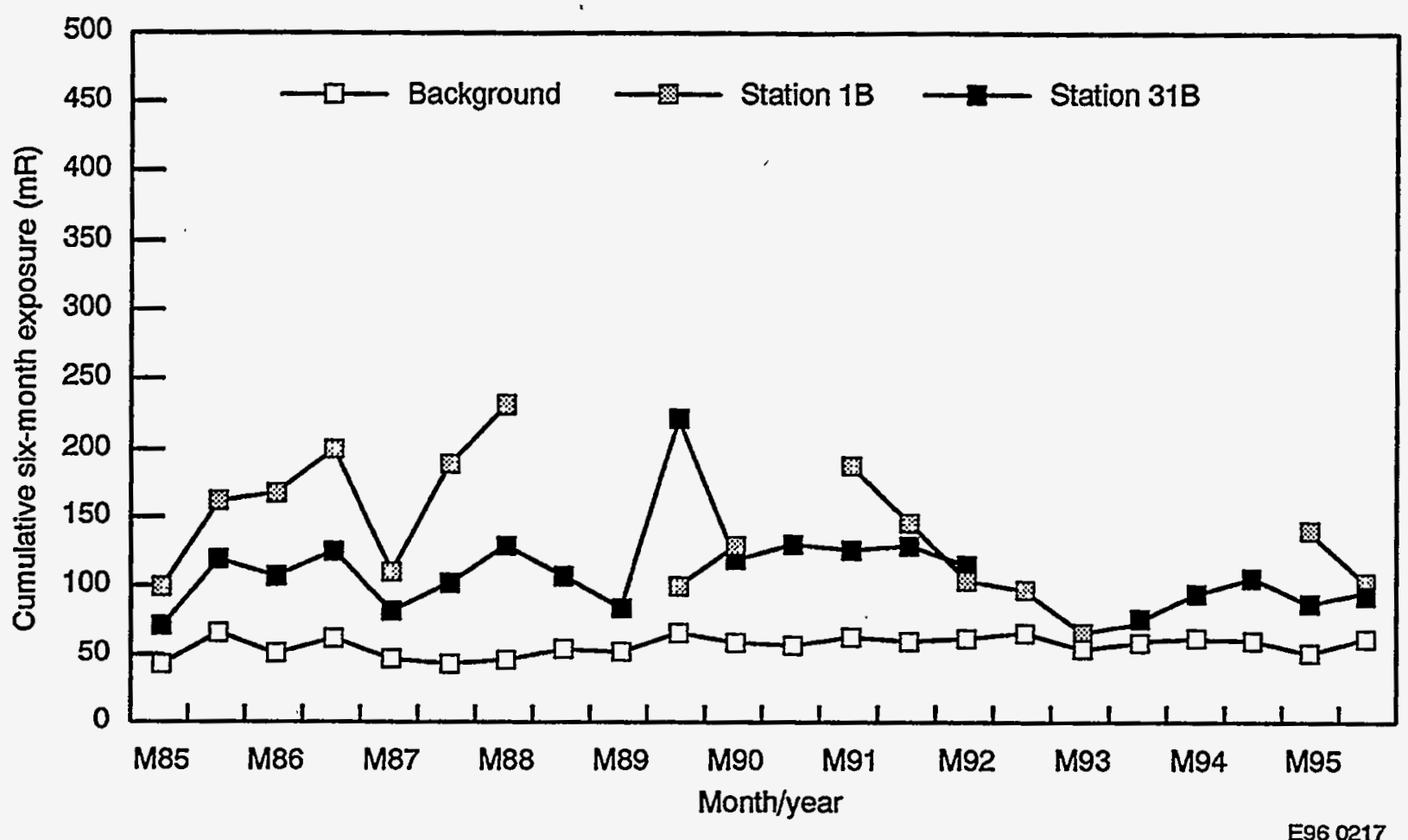

Figure 52. Six-month exposures measured by two of the four TLDs on the east border of the SDA near the active pits.

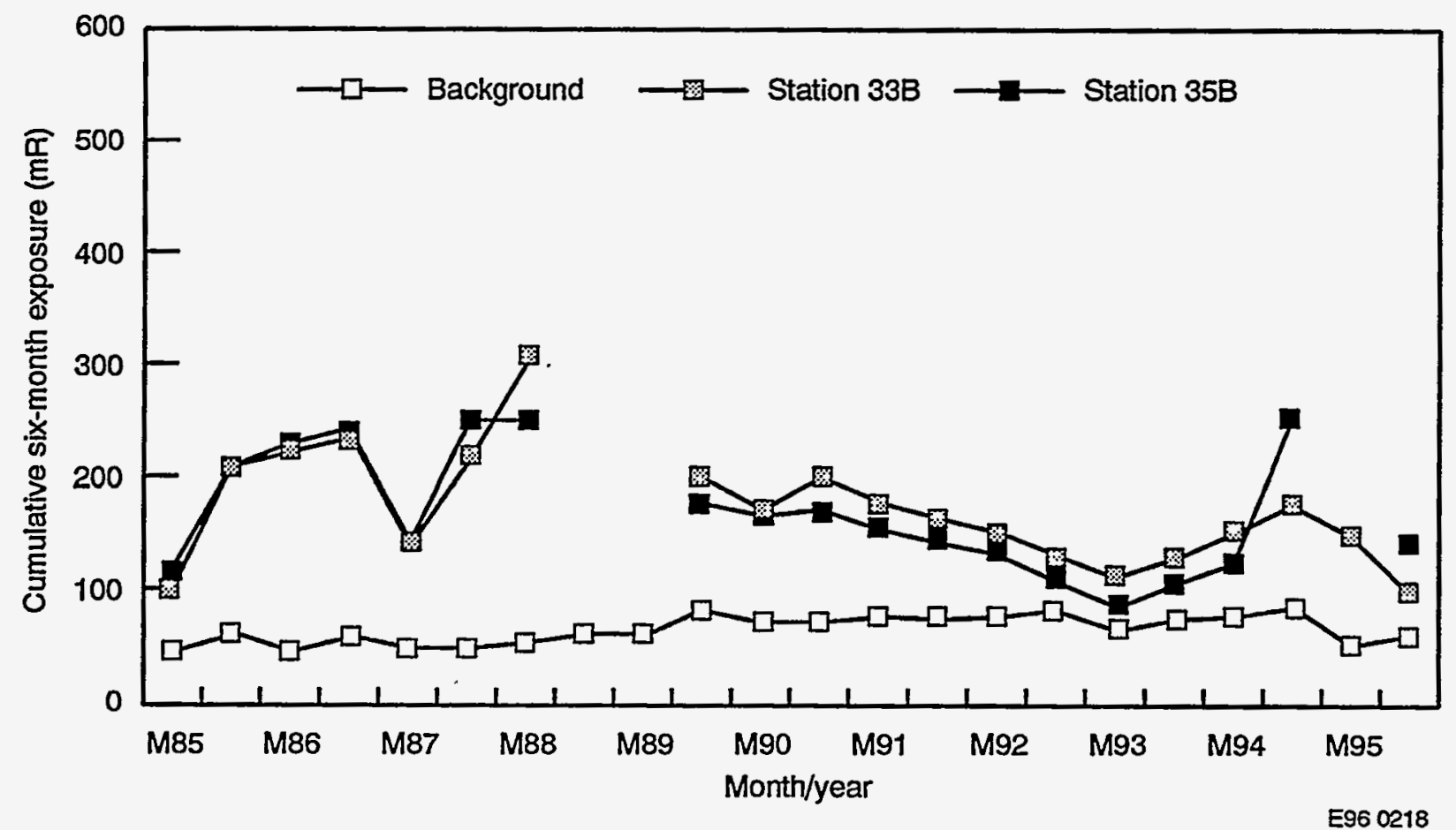

Figure 53. Six-month exposures measured by two of the four TLDs on the east border of the SDA near the active pits. 
Several general observations can be made about the data presented in Figures 46 through 53. First, there is a decreasing trend in exposures over time at most locations around the SDA, especially from 1974 through 1980. (Refer to the 1991 Annual Report ${ }^{16}$ for plotted data beginning approximately in 1973.) Except for the increased exposure around the active pit during 1994, decreases can generally be attributed to the following: (a) changes in operational activities, (b) placement of additional soil over pits and trenches, and (c) radioactive decay of the radionuclides in waste already buried. Many exposures have decreased to near background exposures and tend to vary directly with background exposures.

Approximately $0.6 \mathrm{~m}(2 \mathrm{ft})$ of soil cover was added to the northern half of the SDA in 1976. From 0.3 to $2 \mathrm{~m}$ ( 1 to $7 \mathrm{ft}$ ) of soil cover was added to most of the remaining portion of the SDA in the early 1980 s. In the late 1980 s and early 1990 s, recontouring projects have increased the soil cover over the majority of the SDA.

The second observation indicates that in past years, exposures are generally lower from November through May than from May through November. Lower exposures are attributed to decreased waste handling, increased snow cover, and increased soil moisture.

A general increase was noted at the RWMC during 1994 due to operational activities. These activities were the storage of higher level waste in the bulk waste area within the active disposal pit and waste movement from the Intermediate-Level Transuranic Storage Facility to the C\&S building during the second reporting period of 1994. Most exposures decreased from fall 1994 to spring 1995 and continued a slight decrease from spring 1995 to fall 1995. This decrease is likely due to waste in the active pit being covered with additional soil. Exposures at some stations on the east side of the TSA area increased and are expected to continue to increase as the amount of waste in the Type II storage buildings increases.

Figure 46 plots exposures measured at Stations 9A, 11A, and 13A (along the northwest SDA border). Station $9 \mathrm{~A}$ is located near the west end of $\mathrm{Pad} \mathrm{A}$, and Stations $11 \mathrm{~A}$ and $13 \mathrm{~A}$ are located along the northern part of the original burial ground (operated from 1952 through 1957). This area contains buried LLW intermixed with TRU waste. The exposures at Station 9A have generally decreased over time. Exposures have decreased at Stations $11 \mathrm{~A}$ and $13 \mathrm{~A}$ over the years and remain at or near background levels for both 1995 reporting periods. However, Station 9A increased to approximately twice background during the second reporting period of 1994 due to the operational activities discussed previously. Exposures at Station 9A decreased again during 1995 due to additional soil cover.

Exposures measured at Stations 3A, 5A, and 7A (northeast SDA border) are plotted in Figure 47. Station $3 A$ is located near Pit 9, which contains TRU waste, and Station $5 \mathrm{~A}$ is located near Pit 8 , which contains LLW. Both pits were closed in 1969; however, Pit 9 is currently in the construction phase for clean up. Station 7A is located near the east end of Pad A. During 1985 through 1988, waste was temporarily stored east of these locations and contributed to the increased exposure rate during those years. Exposures returned to twice background from 1989 to the spring of 1994, and increased to nearly three times background during the second reporting period of 1994 . This most recent increase is also due to previously discussed operational activities. During 1995, exposures returned to at or near background levels for both reporting periods.

Figure 48 shows exposures measured at Stations $23 \mathrm{~A}$ and $25 \mathrm{~A}$, which are located along the south-central border of the SDA. The trenches near these stations contain LIW intermixed with TRU waste and were closed in 1959. With the exception of the second reporting period in 1994 for 
Station $25 \mathrm{~A}$, the exposures at these stations have generally decreased over time, and Station $23 \mathrm{~A}$ remains at or near background exposure levels. Exposure levels during 1994 increased due to operational activities in the second reporting period and have decreased during 1995 in proportion to all stations in the proximity of the active pit.

Figure 49 shows exposures measured at Stations $19 \mathrm{~A}$ and $21 \mathrm{~A}$, which are located along the southwest border of the SDA. These stations are located near soil vaults, which are cylindrical holes drilled into the ground. Soil vaults have been designed for disposal of special wastes with radiation levels exceeding $500 \mathrm{mR} / \mathrm{h}$ at $0.91 \mathrm{~m}$ (30 ft). The soil vaults in this area have been closed since 1979 . Since 1982, exposures have continued to be consistently near the background exposure levels.

The exposures plotted in Figure 50 are for Stations 27A and 29A, which are located on the southeast border of the SDA, south of Pit 17 (which is active). Since the early 1980s, before Pit 17 was actively used, the exposures at $27 \mathrm{~A}$ and $29 \mathrm{~A}$ remained consistent at two times the background exposure levels. Until the second reporting period of 1994, exposures have been decreasing and approaching background levels. As stated previously, these stations also showed an increase during the second reporting period of 1994 and a decrease during both 1995 reporting periods due to their proximity to the active pit.

Figure 51 presents plots of exposures measured at Stations 15A and 17A, which are located on the west SDA border (next to the original burial ground). Exposures at these stations have been variable due to operational activities, but generally have decreased over time. Current exposures remain consistent and are at or near background levels.

Figures 52 and 53 show exposures at Stations 1B, 31B, 33B, and 35B (along the east SDA border). These are the closest stations to the pits that have been active since 1974. Generally, exposures measured at these stations have been the highest observed at the SDA and vary with the proximity and intensity of operational activity. Data are no longer available from Stations $1,31,33$, and 35 due to construction in the area. However, data are reported for the second half of 1989 through the present at Stations $1 \mathrm{~B}, 31 \mathrm{~B}, 33 \mathrm{~B}$, and 35B. These locations are $15 \mathrm{~m}$ (16.4 yd) east of the original locations and are closer to the Intermediate-Level Transuranic Storage Facility at TSA. The exposure during the first reporting period for Station 33B was the highest noted in 1995. These stations are in close proximity to the active pit area and also showed an increase in the second reporting period of 1994 and a decrease during both reporting periods of 1995.

Figures 54 through 58 are plots of exposures measured by TLDs along the north, south, and east borders of the TSA, respectively.

Exposures measured at Stations 37A, 39, and SWEPP 1, which are located along the north border of the TSA, are plotted in Figure 54. The exposures at these locations are variable over time. These stations are near an area where incoming shipments are placed until the waste can be disposed. These waste shipments are, in effect, point sources of radiation. Another factor in the variability of the past years exposures at these stations was the temporary storage of waste on the asphalt pad in the TSA area during the late 1980s. Exposures at Station 37A have been decreasing and are approaching background levels. No waste has been stored in this area for the past four years. The exposures at Station 39 and SWEPP 1 have been consistent during the past four years and are approaching the background levels. 


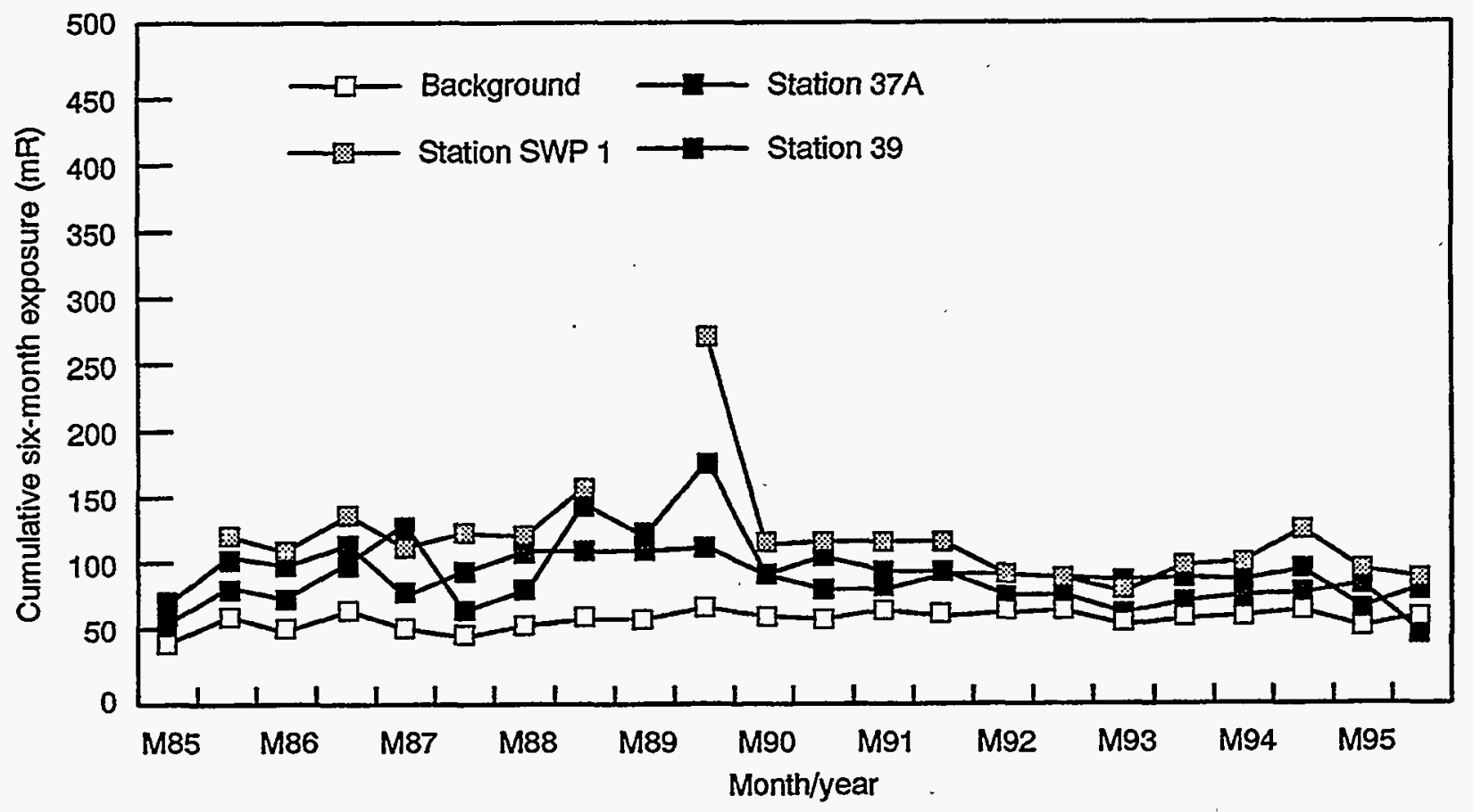

Figure 54. Six-month exposures measured by TLDs on the north border of the TSA.

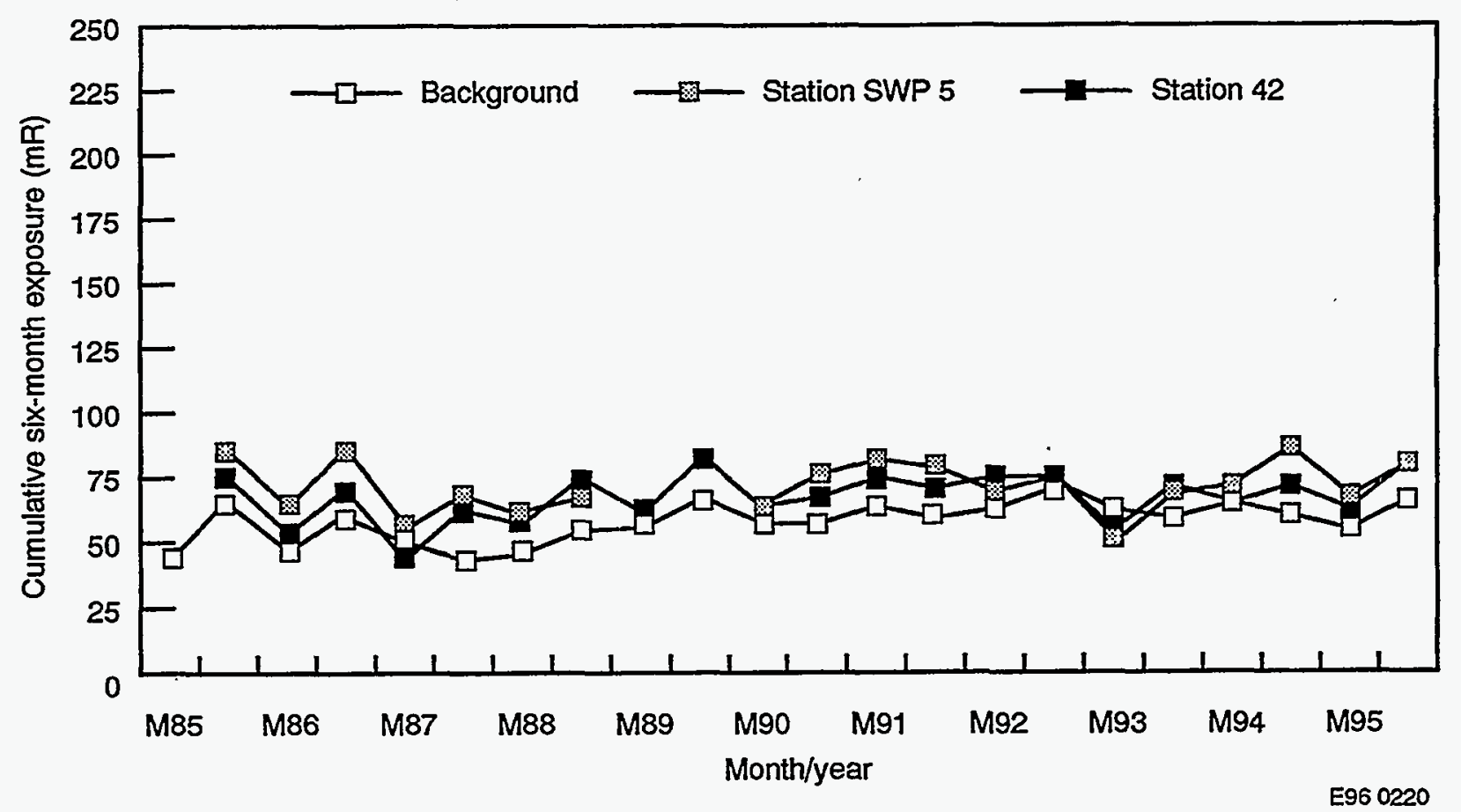

Figure 55. Six-month exposures measured by two of the four TLDs on the south and southeast borders of the TSA. 


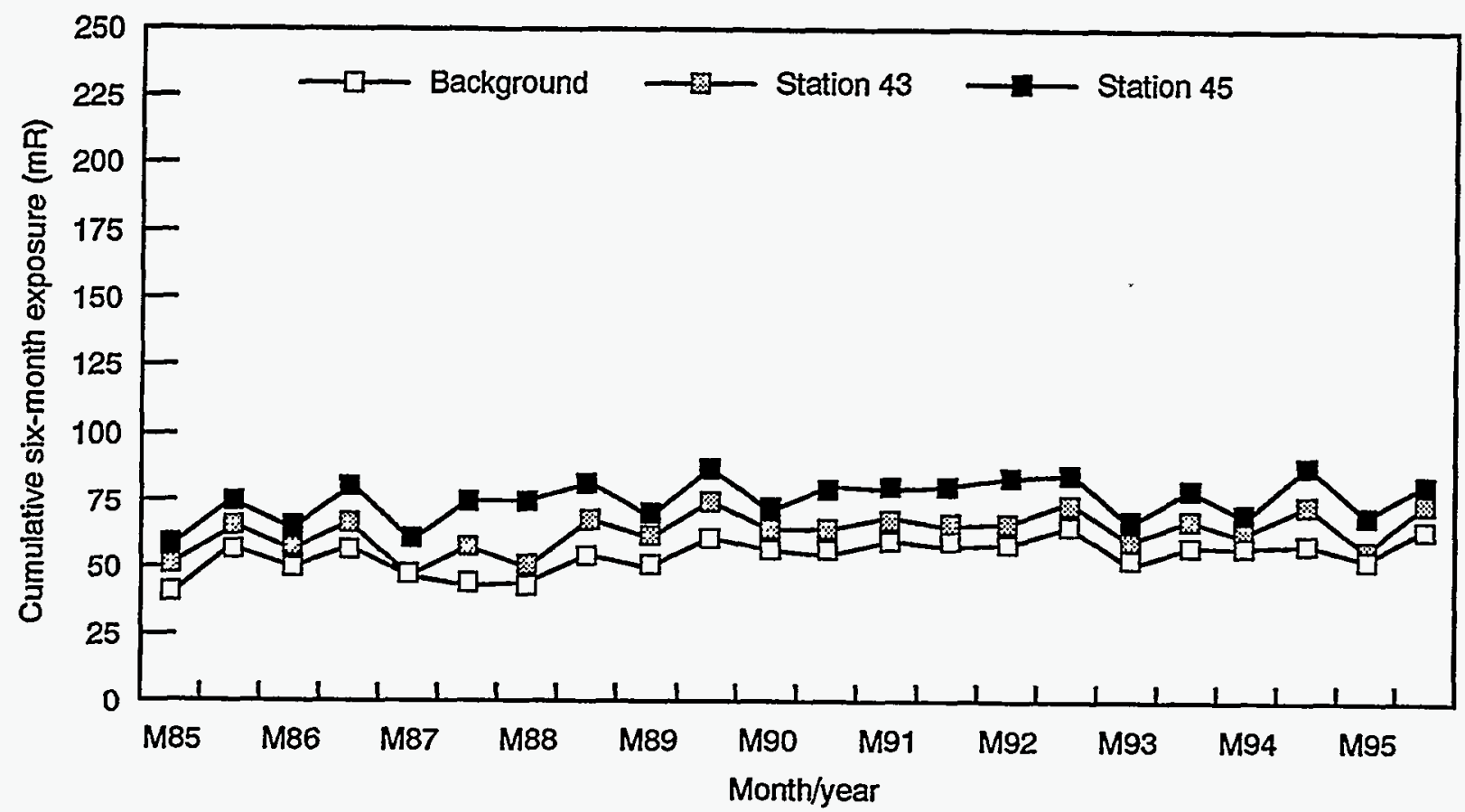

Figure 56. Six-month exposures measured by TLDs on the south border of the TSA.

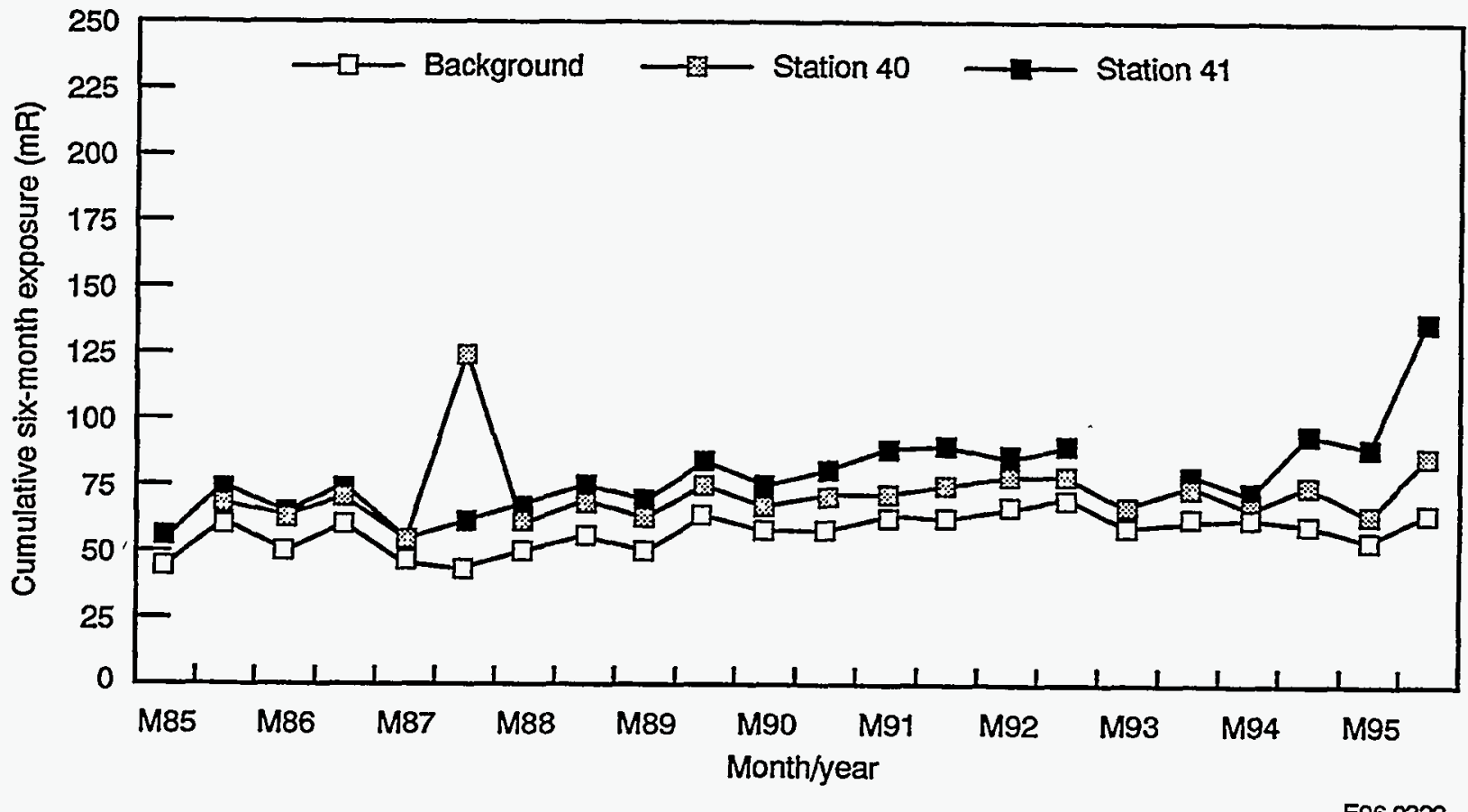

Figure 57. Six-month exposures measured by TLDs on the east and northeast borders of the TSA. 


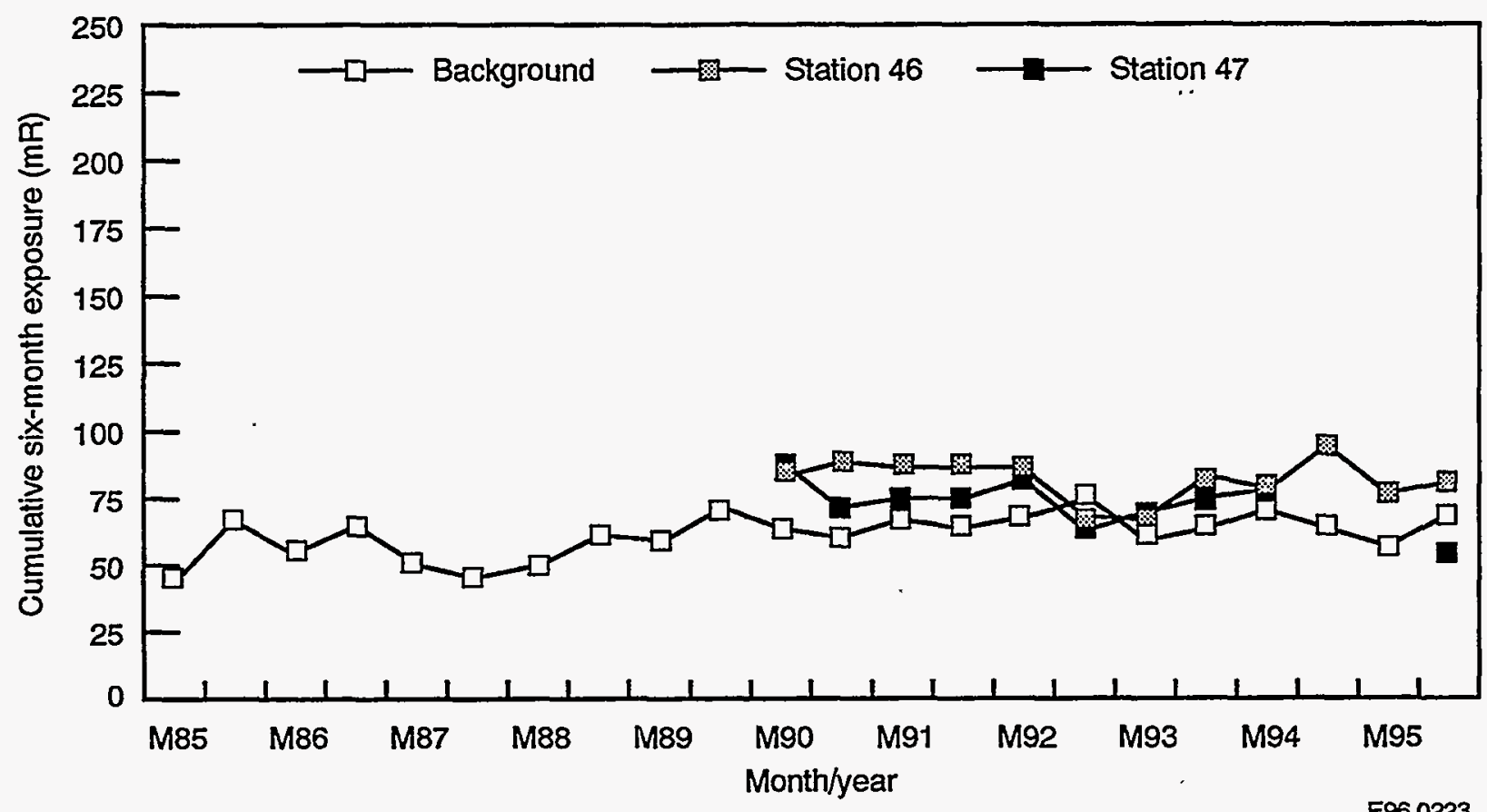

Figure 58. Six-month exposures measured by TLDs north of TSA.

Exposures measured at Stations SWEPP 5, 42, 43, and 45, which are located along the south and southeast borders of the TSA, are shown in Figures 55 and 56. These exposures are consistently low and usually vary directly with background exposures. However, these stations also showed a slight increase during the second reporting period of 1994 and returned to at or near background levels during 1995.

Exposures measured at Stations 40 and 41 , which are located along the east and northeast borders of the TSA, are shown in Figure 57. Station 41 exposures are fairly consistent and are close to background exposures. Station 40 showed a large increase during the second half of 1987, and then returned to its typical range. The 1987 increase has been attributed to the temporary storage of drums near the drum venting station during that year. Exposures at Station 40 and 41 increased significantly due to waste being moved from the TSA-Retrieval Enclosure to building WMF-628. The exposures in this area are likely to continue to increase as the amount of waste in the Type II storage buildings increases.

Figure 58 shows exposures measured at Stations 46 and 47, located along the north border of TSA. In May 1989, the security fence was increased in size, and these two stations were added. These exposures have been fairly consistent with background exposures. However, Station 46 also showed the same, slight increase during the second reporting period of 1994. Exposure data were not reported for Station 47 during the second reporting period of 1994 or the first reporting period of 1995 because the TLD could not be located during change outs. Exposures at Station 46 returned to near background for both reporting periods of 1995, and the data point reported for Station 47 during the second period of 1995 also showed background levels. 


\subsubsection{Waste Experimental Reduction Facility}

Figure 37 shows the locations of the 11 TLD stations located around the WERF. Figures 59 through 63 show the six-month exposures measured by TLDs located in the WERF area.

Figures 59 and 60 show the exposures measured at Stations 1,2,3, and 4, which are located northeast of WERF along the predominant wind direction. Stations $1,2,3$, and 4 are located $500 \mathrm{~m}$ (547 yd), $400 \mathrm{~m}$ (437 yd), $300 \mathrm{~m}$ (328 yd), and $200 \mathrm{~m}$ (219 ft) from WERF, respectively. Exposure levels at these stations remain at or near background with the exception of Station 4, which showed an increase during the first reporting period in 1994. Station 4 is located in the proximity where waste is stored. However, the associated uncertainty on this data point was higher than normal. Exposures during both reporting periods of 1995 returned to background levels.

Figures 61 and 62 show the exposures measured at Stations 5,6,7, and 8, which are located $50 \mathrm{~m}$ (55 yd) from WERF in the following directions, respectively: northeast, southeast, southwest, and northwest. Stations 5 and 8 are located near an area where waste is stored prior to processing. Some variability in exposures, especially at Station 5 , is due to temporary parking and storing waste shipments in those areas; these waste shipments are, in effect, point sources of radiation. This accounts for the increase in exposures at Stations 5 and 8 during 1988 and the continued increase at Station 5 during 1989. Waste stored in the storage area adjacent to Station 8 was removed during the second half of 1989. Part of the waste stored near Station 5 was removed in 1990. Stations 5 and 6 were removed during 1992 due to construction in the area and was replaced during 1993 at the same locations. Exposures at these locations returned to near background levels during 1995. Exposures at Stations 7 and 8 are close to background exposures; however, a slight increase was noted during the first reporting period of 1995 at Station 8 . This increase is likely due to a waste shipment being parked in this area. Exposures at Stations 5 and 6 increased during 1994 due to additional waste being stored in these areas and returned to background levels during both reporting periods of 1995.

Figure 63 shows the exposures measured at Stations 9, 10, and 11; which are located $400 \mathrm{~m}$ (437 yd) from the WERF area in the following directions; respectively: northwest, southwest, and southeast. The exposures at each of these stations have remained fairly consistent over time and remain consistent with background exposures.

\subsection{Surface Radiation}

To conduct the surface gamma-radiation surveys, a vehicle-mounted roadway monitor-number one (VRM-1) gamma-radiation detector system using plastic scintillation detectors (shown in

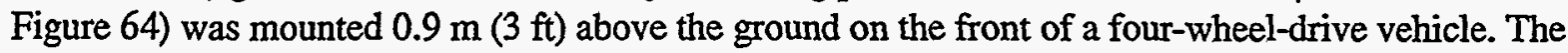
vehicle was driven at approximately $5 \mathrm{~km} / \mathrm{h}(3 \mathrm{mph})$ across each area. As radiation levels greater than background levels were identified, the vehicle was stopped and the area was surveyed with a gamma-sensitive portable instrument. Any areas exceeding the facility limits were marked with flagged stakes for subsequent covering with additional soil.

\subsubsection{Radioactive Waste Management Complex}

The contact radiation readings of the 1995 spring and fall surveys at the RWMC are shown in Figure 65 . All areas surveyed outside of the active pit were below the limit of $1 \mathrm{mR} / \mathrm{h}$ at $0.9 \mathrm{~m}(3 \mathrm{ft})$, as specified by the RWMC Project Directives. ${ }^{17}$ The $1-\mathrm{mR} / \mathrm{h}$ criterion at $0.9 \mathrm{~m}(3 \mathrm{ft})$ ensures that personnel are not subjected to significant radiation exposure. 


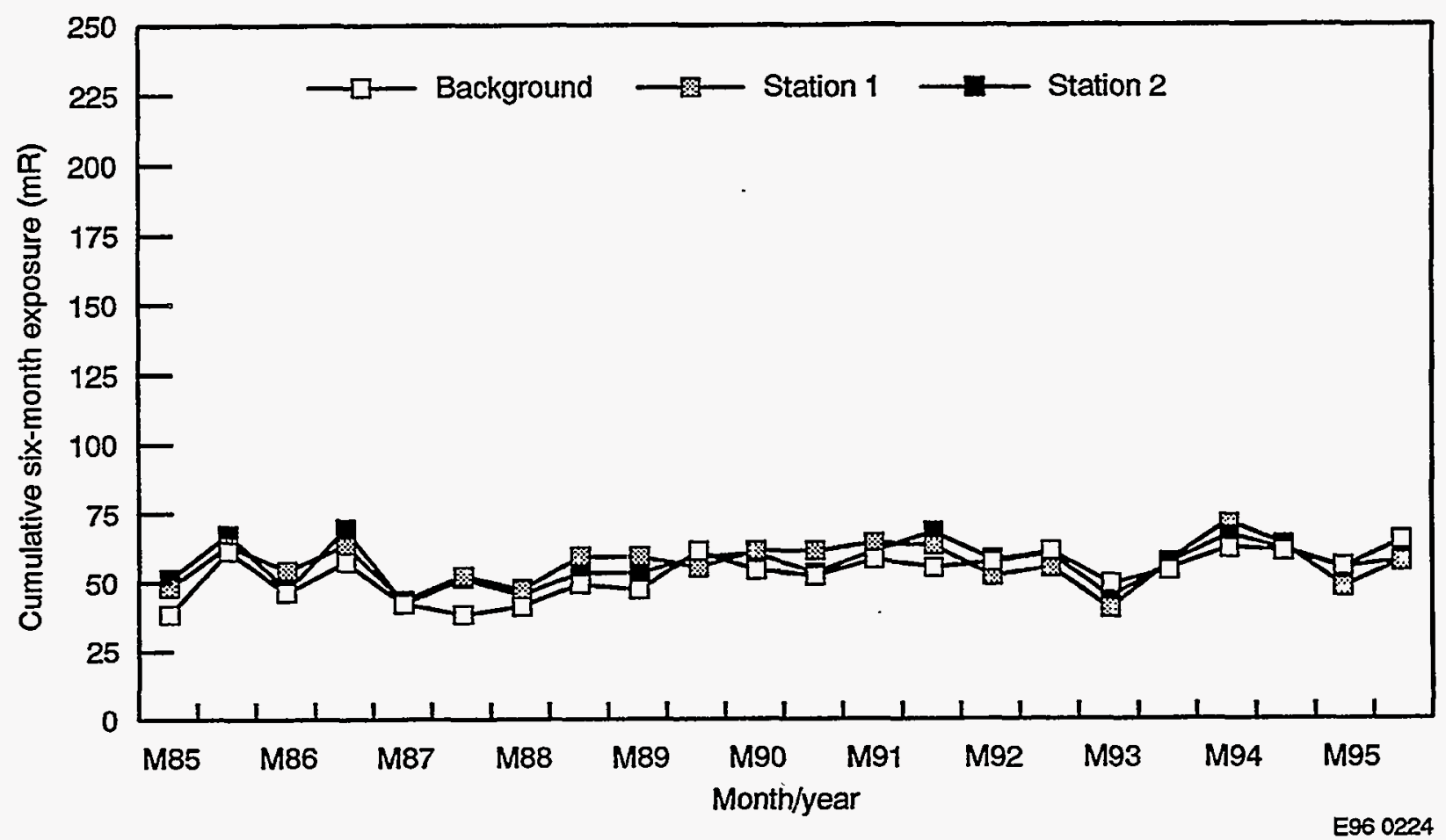

Figure 59. Six-month exposures measured by TLDs located 500 and $400 \mathrm{~m}$ northeast of WERF.

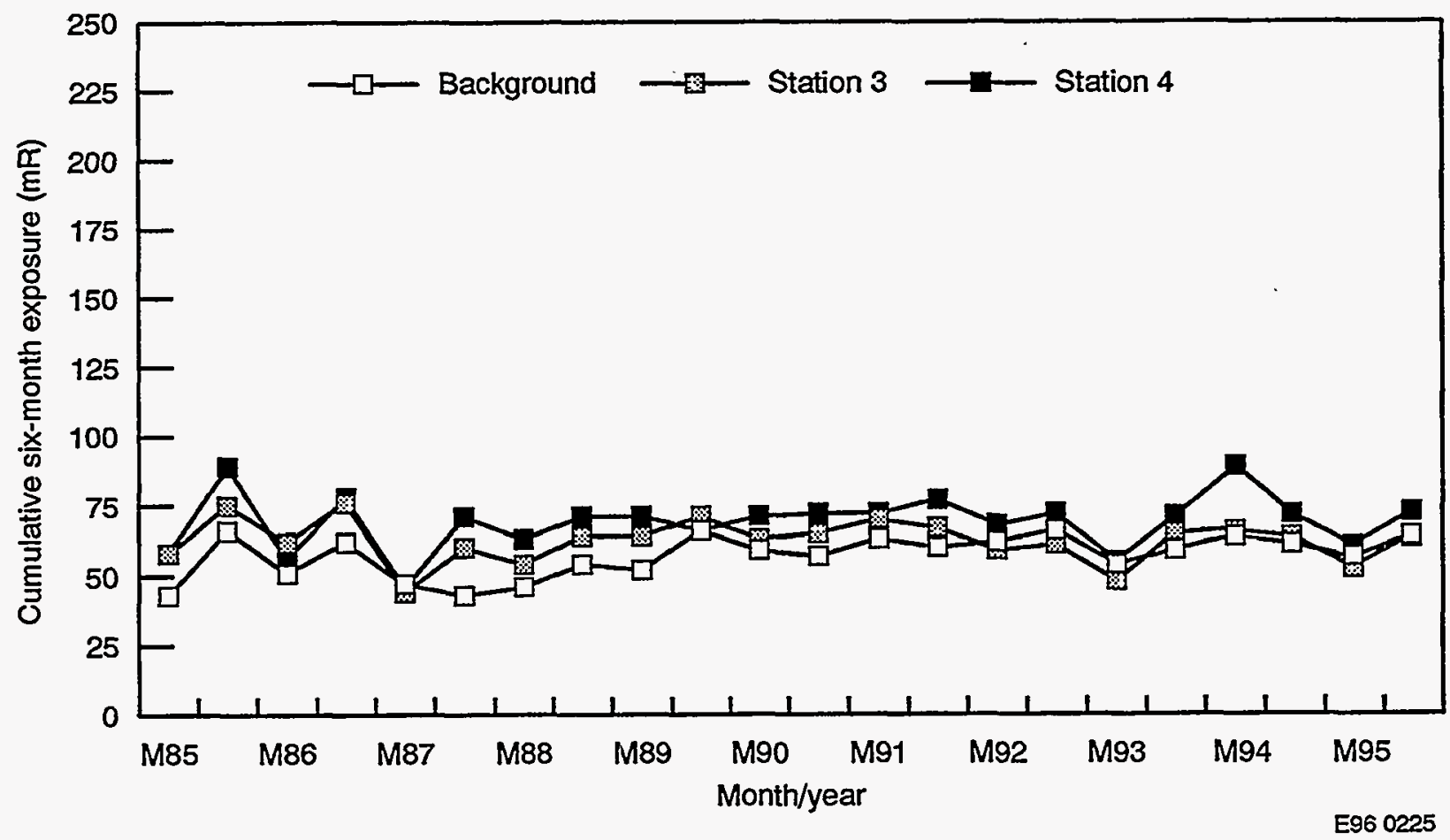

Figure 60. Six-month exposures measured by TLDs located 300 and $200 \mathrm{~m}$ northeast of WERF. 


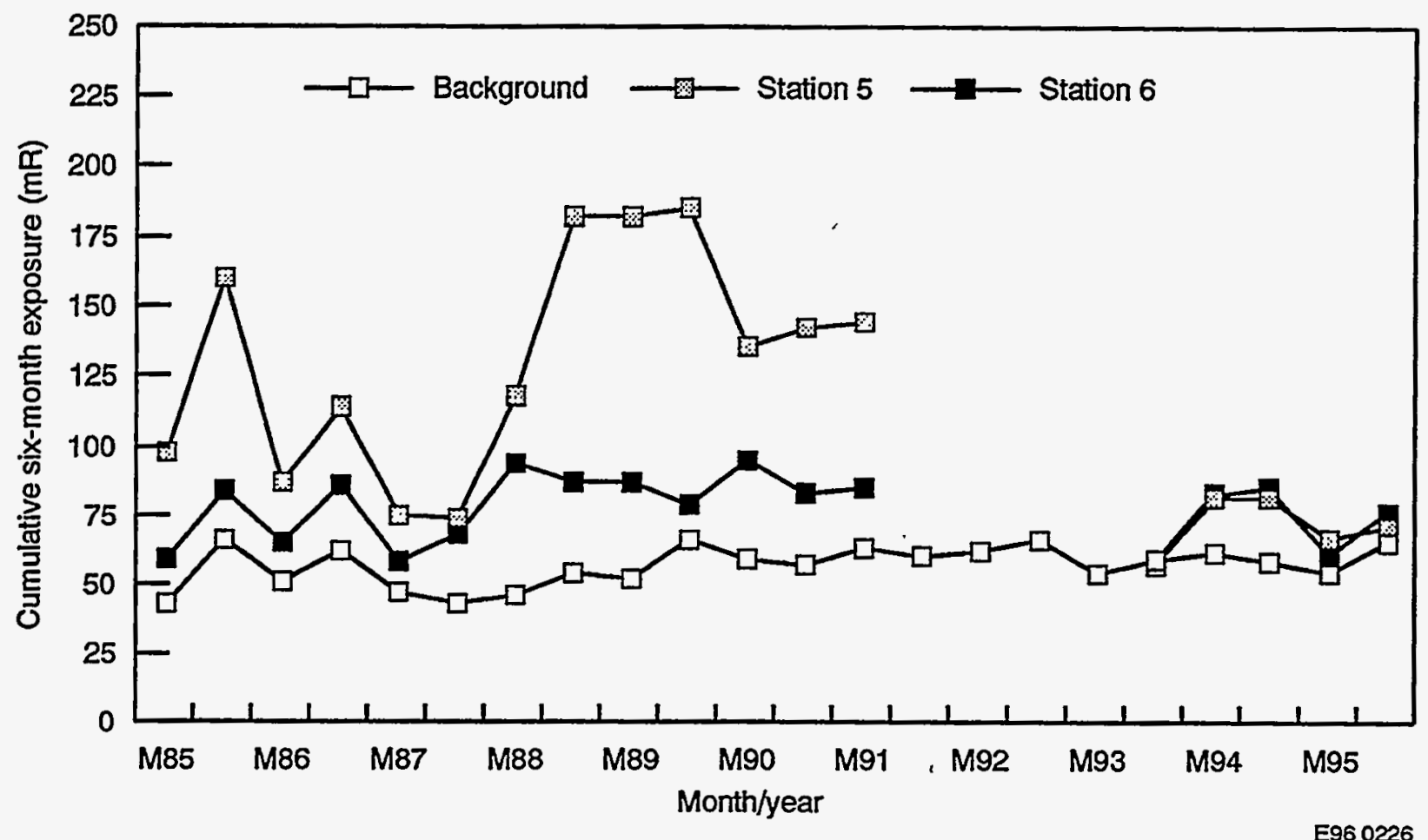

Figure 61. Six-month exposures measured by TLDs located northeast and southeast of the 50-m perimeter around WERF.

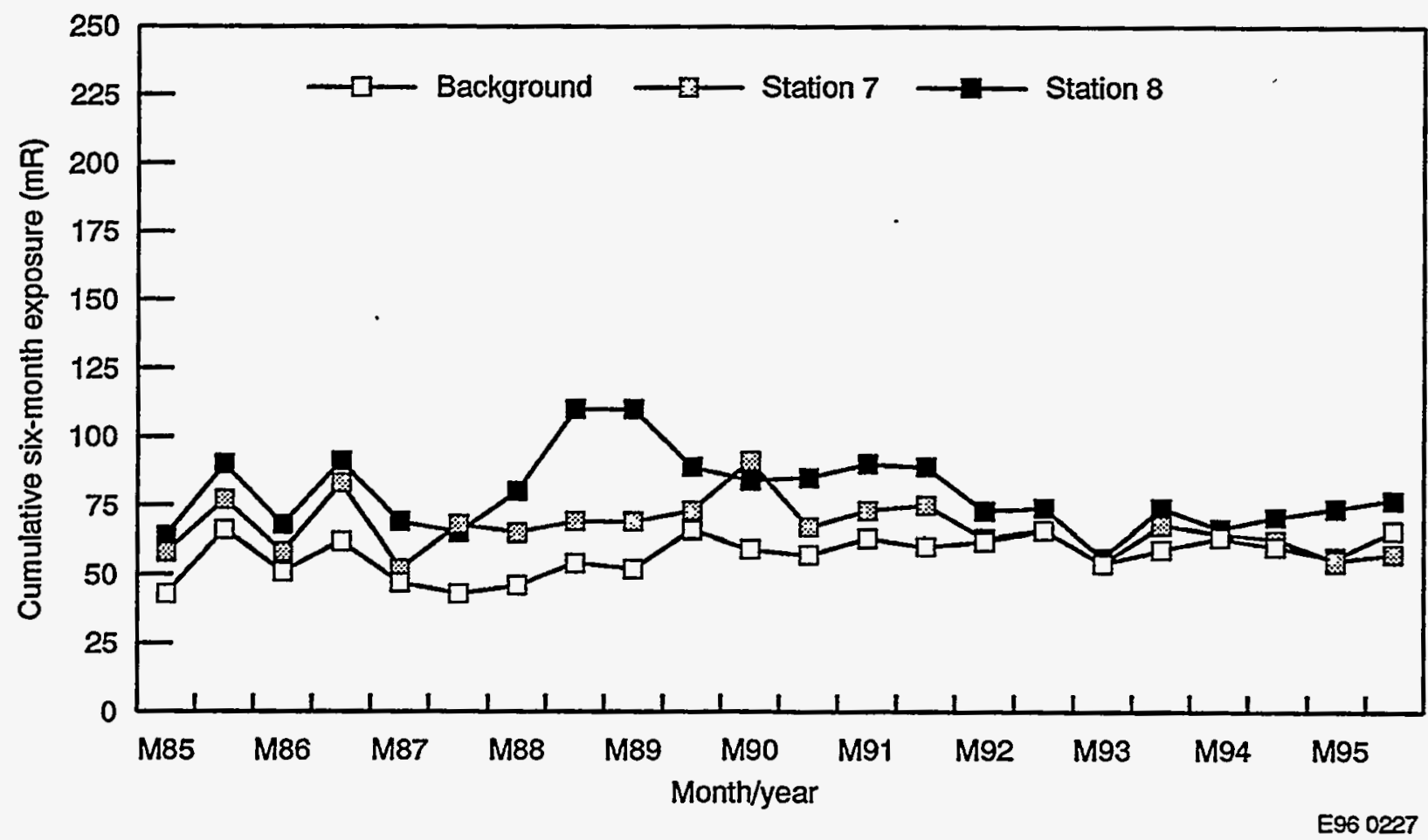

Figure 62. Six-month exposures measured by TLDs located northwest and southwest of the 50 -m perimeter around WERF. 


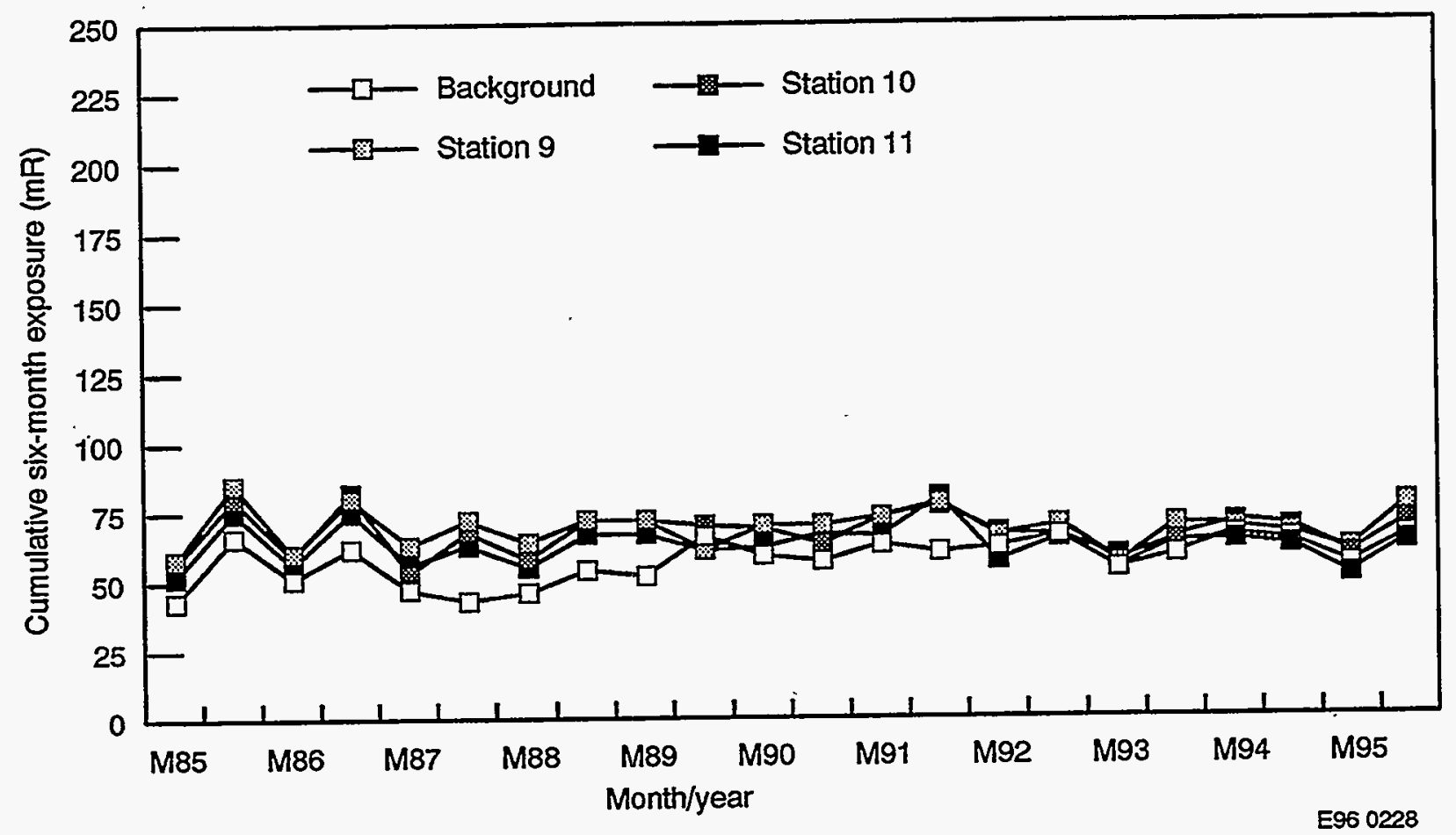

Figure 63. Six-month exposures measured by TLDs located northwest, southwest, and southeast of the perimeter around WERF.

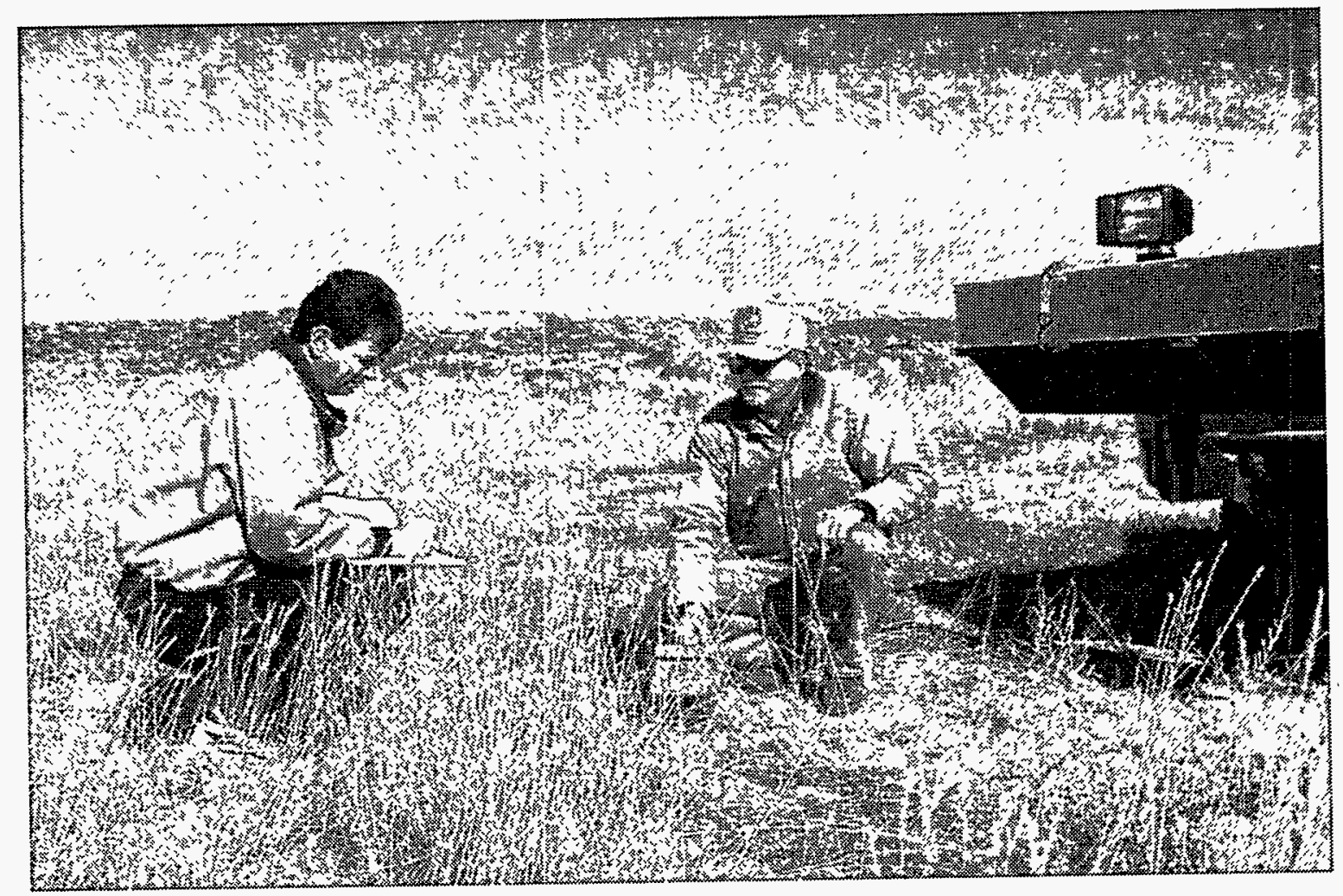

Figure 64. VRM-1 and HHD-440 meter radiation detector system (photo number DP960017). 

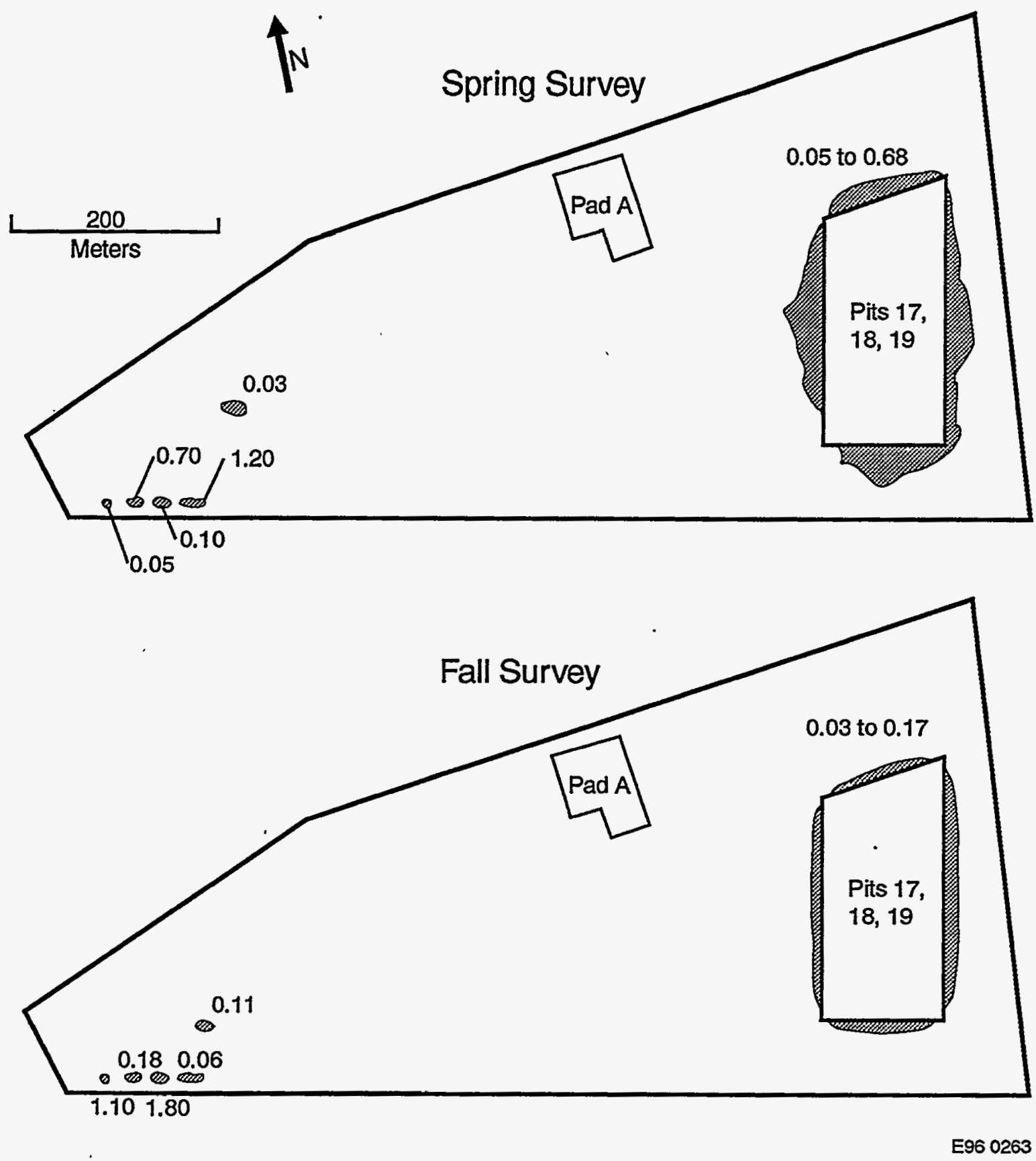

NOTE: All values are in $\mathrm{mR} / \mathrm{h}$ and are read at contact with the exception of the range identified for the parameter of the open pit.

Figure 65. Results of 1995 spring and fall RWMC surface radiation surveys. 
Background radiation levels $(0.008 \mathrm{mR} / \mathrm{h})$ were exceeded in several locations. The locations of these areas were documented and will be surveyed again in the future. With the exception of the area around the active pit, the highest reading noted in both surveys was $1.80 \mathrm{mR} / \mathrm{h}$ at contact and $0.40 \mathrm{mR} / \mathrm{h}$ at $0.91 \mathrm{~m}$ ( $3 \mathrm{ft})$. This location was found along Soil Vault Row 7.

The decreased radiation levels shown on the sides of the active pit from spring to fall were a result of soil added during the summer of 1995 . No new areas were identified during either the spring or fall survey that had not already been identified in earlier surveys.

\subsubsection{Stationary Low-Power Reactor No. 1}

The SL-1 area location is shown in Figure 1. Results of the spring and fall surface radiation surveys of the SL-1 surplus area identified no areas that exceeded the action level of $20 \mathrm{mR} / \mathrm{h}$ gamma at or near contact. During the fall survey, one particle was identified that exceeded the criteria. It was located in the southwest comer of the burial ground, and was a beta particle reading $500 \mathrm{mR} / \mathrm{hr}$, open window, at contact. The Radiological Control Technician supporting the survey remediated the particle.

\subsubsection{Organic-Moderated Reactor Experiment}

The OMRE survey was not conducted during 1995 due to equipment problems with the global positioning radiometric scanner (see Figure 66). This survey will be conducted in the spring of 1996 and results reported in the 1996 annual report.

\subsection{Groundwater}

The USGS routinely samples groundwater from monitoring wells located in and adjacent to the RWMC (see Figure 67). Immediately surrounding the RWMC are USGS Wells 87, 88, 89, 90, 117, 119 , and 120, which penetrate the Eastern Snake River Plain aquifer approximately $180 \mathrm{~m}(591 \mathrm{ft})$ beneath the surface. USGS Well 92, located in the west central portion of the SDA, is used for collecting perched groundwater samples and monitoring the depth to perched water. In 1973, the well was sealed with expanding concrete at a dense basaltic zone about $65 \mathrm{~m}(213 \mathrm{ft})$ below the surface, so that perched water could accumulate. Due to the removal of water during sampling, the water level varies between 63.3 and $64.0 \mathrm{~m}(207.7$ and $210.0 \mathrm{ft})$ below the surface.

Each quarter, the USGS measures specific conductance, $\mathrm{pH}$, temperature, and chloride, as well as H-3 and Sr-90. During 1995, samples from Wells 87, 88, 89, 90, 117, 119, 120, and the RWMC Production Well were analyzed for gamma-emitting radionuclides (i.e., Co-60 and Cs-137), and TRU radionuclides ( $\mathrm{Pu}-238, \mathrm{Pu}-239,-240$, and $\mathrm{Am}-241)$. The RWMC Production Well is sampled monthly for purgeable organic compounds while all other wells, except Well 92, are sampled quarterly. Well 92 was not sampled during 1995 for any constituents due to the insufficient amount of water in the well.

Since operations began at the INEL in the 1950s, wastewater disposal at the INEL has increased the specific conductance of groundwater in the vicinity of INEL facilities. The background specific conductance of water from the Eastern Snake River Plain at the INEL generally ranged from $178-860 \mu \mathrm{S} / \mathrm{cm} .{ }^{18}$ This range was compared to the specific conductance measurements of water samples collected from wells at the RWMC in 1995 (see Table 6). These specific conductance measurements are comparable to those made in previous years. 


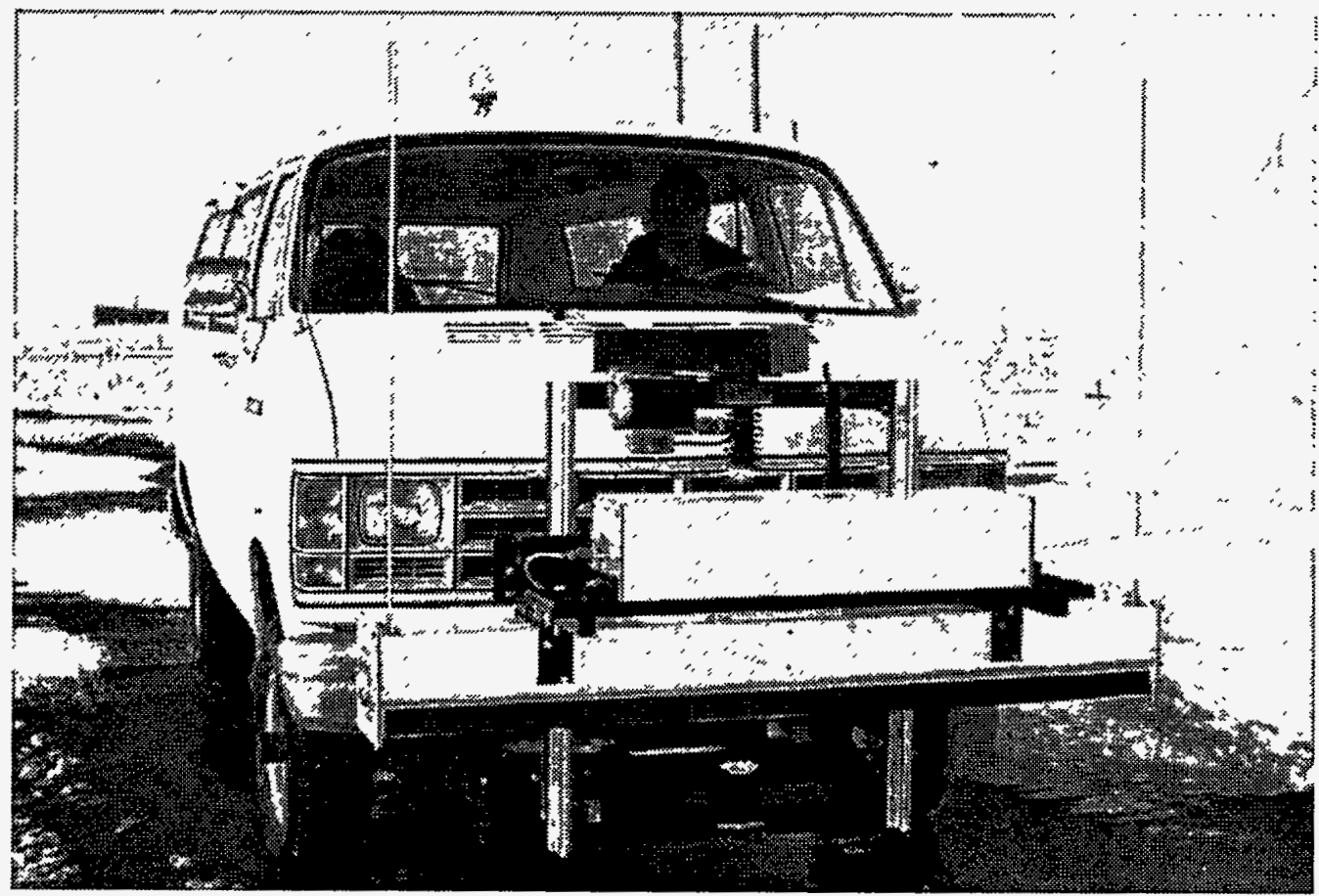

Figure 66. Global positioning system (photo number 92-561-1-2).

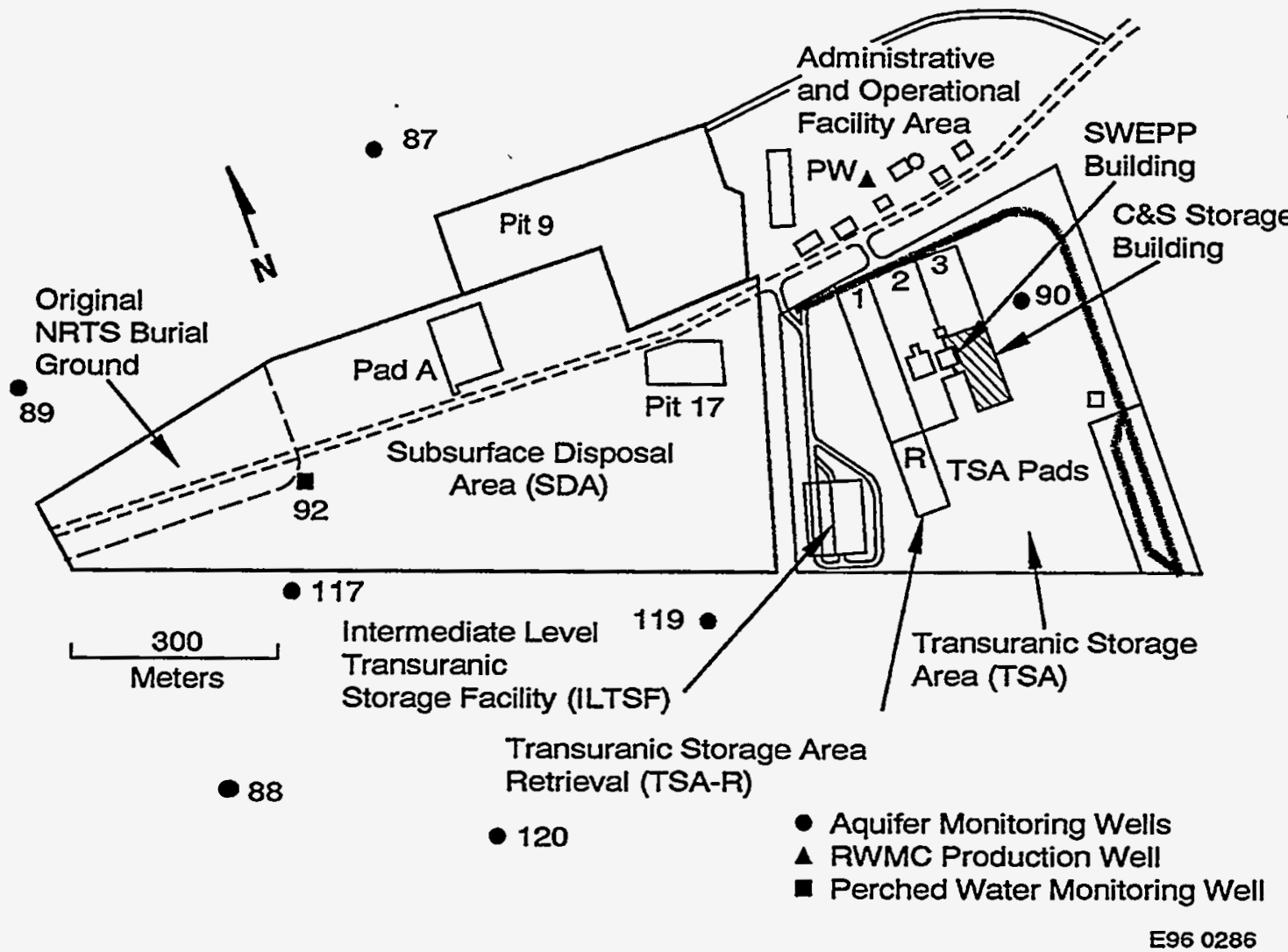

Figure 67. USGS well locations. 
Table 6. Results of chemical analyses of subsurface water at the RWMC in 1995.

\begin{tabular}{|c|c|c|c|c|}
\hline \multirow[b]{2}{*}{ Well } & \multirow[b]{2}{*}{ Month Sampled } & \multirow{2}{*}{$\begin{array}{c}\text { Specific } \\
\text { Conductance } \\
\mu S / \mathrm{cm}\end{array}$} & \multicolumn{2}{|c|}{ Concentration (mg/L) } \\
\hline & & & $\mathrm{Cl}^{-}$ & $\mathrm{Na}^{+}$ \\
\hline \multirow[t]{4}{*}{87} & January & 350 & 14 & $一^{a}$ \\
\hline & April & 360 & 15 & 11 \\
\hline & July & 350 & 12 & - \\
\hline & October & 352 & 13 & 10 \\
\hline \multirow[t]{4}{*}{88} & January & 571 & 83 & - \\
\hline & April & 581 & 83 & - \\
\hline & July & 580 & 83 & - \\
\hline & October & 586 & 82 & 44 \\
\hline \multirow[t]{4}{*}{89} & January & 384 & 13 & - \\
\hline & April & 387 & 39 & - \\
\hline & July & 385 & 38 & - \\
\hline & October & 379 & 37 & 20 \\
\hline \multirow[t]{4}{*}{90} & January & 361 & 14 & - \\
\hline & April & 370 & 14 & - \\
\hline & July & 366 & 14 & - \\
\hline & October & 370 & 15 & 9.1 \\
\hline \multirow[t]{4}{*}{117} & January & 272 & 39 & 一 \\
\hline & April & 275 & 14 & - \\
\hline & July & 275 & 13 & 一 \\
\hline & October & 277 & 13 & 11 \\
\hline \multirow[t]{4}{*}{119} & January & 271 & 8.5 & 一 \\
\hline & April & 279 & 9.6 & - \\
\hline & July & 273 & 9.5 & - \\
\hline & October & 277 & 8.7 & 11 \\
\hline
\end{tabular}


Table 6. (continued).

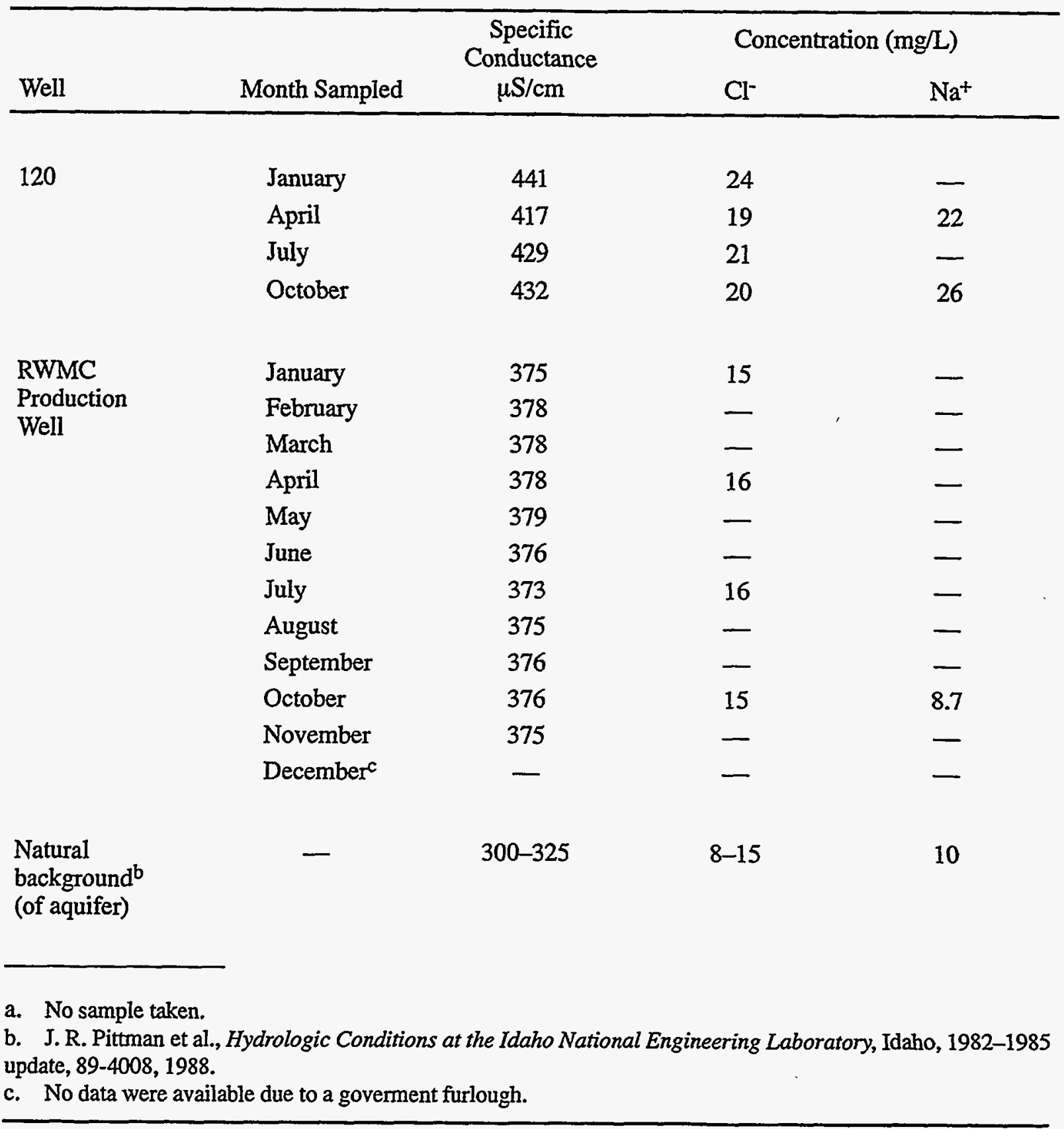

The chloride concentration (see Table 6) was also above background levels ( $8-15 \mathrm{mg} / \mathrm{L}$ ) but well below the secondary maximum contaminant level, which is $250 \mathrm{mg} / \mathrm{L}$ for chloride. The elevated chloride concentrations may be attributed to the same cause as the high sodium concentrations. Both the chloride and sodium concentrations are comparable to concentrations from previous years at these well locations.

During 1995, analyses for stable Na-22 were conducted (see Table 6). Water from some of the RWMC monitoring wells contained sodium concentrations that exceeded the background level of $10 \mathrm{mg} / \mathrm{L}$ (shown in Table 6). Sodium concentrations have fluctuated in water from these wells. One possible cause for these fluctuations is the method used to construct the wells. During construction, the 
wells were pressure-grouted to prevent water from cascading from perched zones down to the SRPA. The grout mixture could contribute to higher sodium concentrations.

Approximately $330,000 \mathrm{~L}$ (87,179 gallons) of organic waste were disposed prior to 1970 at the RWMC. ${ }^{19}$ These buried wastes included about $92,000 \mathrm{~L}$ (24,304 gallons) of carbon tetrachloride, $148,000 \mathrm{~L}$ (39,098 gallons) of lubricating oil, and about 95,000 L (25,097 gallons) of other organic compounds, including trichloroethane, trichloroethylene, perchloroethylene, toluene, and benzene.

Table 7 shows the 1995 concentrations of volatile organic compounds (VOCs) at USGS monitoring wells. The 1995 results are comparable to previous data, with the exception of carbon tetrachloride in Wells 87,88 , and 90 at the RWMC. No MCLs for VOCs or radiological constituents were exceeded during 1995. Although no MCLs were exceeded, carbon tetrachloride concentration levels appeared to gradually increase in these three wells over the past three years (see Figure 68). The results of the gamma spectrometry analysis performed on well samples taken in 1995 showed no positive detections of any gamma-emitting radionuclide.

Tritium was detected in Well 87, Well 90, and in the RWMC Production Well (see Table 8). The maximum concentration of tritium was $1.7 \mathrm{E}-6 \mu \mathrm{Ci} / \mathrm{mL}$ in the RWMC Production Well with a standard deviation of $0.2 \mathrm{E}-6 \mu \mathrm{Ci} / \mathrm{mL}$. This concentration is well below the DCG for the public (less than $0.1 \%$ of the DCG, as shown in Table D-1). Tritium concentrations in these wells are plotted in Figure 69. The source of the tritium is attributed to past disposal of wastewater from operations at the Idaho Chemical Processing Plant (ICPP) and Test Reactor Area (TRA) as reported by Orr and Cecil. ${ }^{18}$

In 1994, Pu-238 was detected in Well 92 at a concentration of $3.9 \pm 0.5 \mathrm{E}-10 \mu / \mathrm{mL}$. This concentration is $1 \%$ of the DCG for Pu-238. Again, Well 92 was not sampled in 1995 because of the lack of water.

Sr-90 was detected in a duplicate sample collected at Well 87. The concentration was $2.7 \pm 0.8$ $\mathrm{E}-9 \mu \mathrm{Ci} / \mathrm{mL}$, which is $0.27 \%$ of the DCG. Other radionuclides were not detected in the wells in any quarter. Additional information regarding the RWMC wells may be found in the Compliance Monitoring Annual Report, ${ }^{20}$ the INEL Site Environmental Report, ${ }^{21}$ and, the Environmental Restoration reports. These reports are available through Administrative Records Document Control. 
Table 7. Concentrations $(\mu \mathrm{g} / \mathrm{L})$ of selected volatile organic compounds in groundwater.

\begin{tabular}{|c|c|c|c|c|c|c|c|c|c|c|}
\hline $\begin{array}{c}\text { Well } \\
\text { Identifier }\end{array}$ & $\begin{array}{c}\text { Date } \\
\text { Sampled }\end{array}$ & $\begin{array}{l}\text { Carbon } \\
\text { Tetra- } \\
\text { chloride }\end{array}$ & $\begin{array}{l}\text { Chloro- } \\
\text { form }\end{array}$ & $\begin{array}{c}1,1,1- \\
\text { Trichloro- } \\
\text { ethane }\end{array}$ & $\begin{array}{l}\text { Trichloro- } \\
\text { ethylene }\end{array}$ & $\begin{array}{l}\text { Tetrachlo- } \\
\text { roethylene }\end{array}$ & $\begin{array}{l}\text { Dichloro- } \\
\text { difluoro- } \\
\text { methane }\end{array}$ & Toluene & $\begin{array}{l}\text { 1,1- } \\
\text { Dichloro- } \\
\text { ethane }\end{array}$ & $\begin{array}{c}1,1- \\
\text { Dichloro- } \\
\text { ethylene }\end{array}$ \\
\hline \multirow[t]{4}{*}{87} & $1 / 95$ & 1.9 & $<0.2$ & 0.2 & 0.4 & $<0.2$ & $<0.2$ & $<0.2$ & $<0.2$ & $<0.2$ \\
\hline & $4 / 95$ & 1.6 & $<0.2$ & $<0.2$ & 0.4 & $<0.2$ & $<0.2$ & $<0.2$ & $<0.2$ & $<0.2$ \\
\hline & $7 / 95$ & 1.6 & $<0.2$ & $<0.2$ & 0.5 & $<0.2$ & $<0.2$ & $<0.2$ & $<0.2$ & $<0.2$ \\
\hline & $10 / 95$ & 1.7 & $<0.2$ & $<0.2$ & 0.4 & $<0.2$ & $<0.2$ & $<0.2$ & $<0.2$ & $<0.2$ \\
\hline \multirow[t]{4}{*}{$88^{a}$} & $1 / 95$ & 1.6 & 0.4 & 0.2 & 0.7 & $<0.2$ & $<0.2$ & $<0.2$ & $<0.2$ & $<0.2$ \\
\hline & $4 / 95$ & 1.6 & 0.4 & 0.2 & 0.7 & $<0.2$ & $<0.2$ & $<0.2$ & $<0.2$ & $<0.2$ \\
\hline & $7 / 95$ & 1.6 & 0.4 & 0.2 & 0.8 & $<0.2$ & $<0.2$. & $<0.2$ & $<0.2$ & $<0.2$ \\
\hline & $10 / 95$ & 1.9 & 0.4 & 0.2 & 0.8 & $<0.2$ & $<0.2$ & $<0.2$ & $<0.2$ & $<0.2$ \\
\hline \multirow[t]{4}{*}{89} & $1 / 95$ & $-b$ & - & - & - & - & - & - & - & - \\
\hline & $4 / 95$ & $<0.2$ & $<0.2$ & $<0.2$ & $<0.2$ & $<0.2$ & $<0.2$ & $<0.2$ & $<0.2$ & $<0.2$ \\
\hline & $7 / 95$ & - & - & - & - & - & - & - & 一 & - \\
\hline & $10 / 95$ & $<0.2$ & $<0.2$ & $<0.2$ & $<0.2$ & $<0.2$ & $<0.2$ & $<0.2$ & $<0.2$ & $<0.2$ \\
\hline \multirow[t]{4}{*}{90} & $1 / 95$ & 2.2 & $<0.2$ & 0.3 & 0.8 & $<0.2$ & $<0.2$ & $<0.2$ & $<0.2$ & $<0.2$ \\
\hline & $4 / 95$ & 1.9 & $<0.2$ & 0.3 & 0.8 & $<0.2$ & $<0.2$ & $<0.2$ & $<0.2$ & $<0.2$ \\
\hline & $7 / 95$ & 1.8 & $<0.2$ & 0.3 & 0.8 & $<0.2$ & $<0.2$ & $<0.2$ & $<0.2$ & $<0.2$ \\
\hline & $10 / 95$ & 2.2 & 0.2 & 0.3 & 0.9 & $<0.2$ & $<0.2$ & $<0.2$ & $<0.2$ & $<0.2$ \\
\hline \multirow[t]{4}{*}{117} & $1 / 95$ & - & - & - & - & - & - & - & - & - \\
\hline & $4 / 95$ & $<0.2$ & $<0.2$ & $<0.2$ & $<0.2$ & $<0.2$ & $<0.2$ & $<0.2$ & $<0.2$ & $<0.2$ \\
\hline & $7 / 95$ & - & - & - & - & - & - & - & - & - \\
\hline & $10 / 95$ & $<0.2$ & $<0.2$ & $<0.2$ & $<0.2$ & $<0.2$ & $<0.2$ & $<0.2$ & $<0.2$ & $<0.2$ \\
\hline \multirow[t]{2}{*}{119} & $1 / 95$ & - & - & - & - & - & - & - & - & - \\
\hline & $4 / 95$ & $<0.2$ & $<0.2$ & $<0.2$ & $<0.2$ & $<0.2$ & $<0.2$ & $<0.2$ & $<0.2$ & $<0.2$ \\
\hline
\end{tabular}


Table 7. (continued).

\begin{tabular}{|c|c|c|c|c|c|c|c|c|c|c|}
\hline $\begin{array}{c}\text { Well } \\
\text { Identifier }\end{array}$ & $\begin{array}{c}\text { Date } \\
\text { Sampled }\end{array}$ & $\begin{array}{l}\text { Carbon } \\
\text { Tetra- } \\
\text { chloride }\end{array}$ & $\begin{array}{l}\text { Chloro- } \\
\text { form }\end{array}$ & $\begin{array}{l}1,1,1- \\
\text { Trichloro- } \\
\text { ethane }\end{array}$ & $\begin{array}{l}\text { Trichloro- } \\
\text { ethylene }\end{array}$ & $\begin{array}{l}\text { Tetrachlo- } \\
\text { roethylene }\end{array}$ & $\begin{array}{l}\text { Dichloro- } \\
\text { difluoro- } \\
\text { methane }\end{array}$ & Toluene & $\begin{array}{l}1,1- \\
\text { Dichloro- } \\
\text { ethane }\end{array}$ & $\begin{array}{c}1,1- \\
\text { Dichloro- } \\
\text { ethylene }\end{array}$ \\
\hline \multirow{6}{*}{120} & $7 / 95$ & - & - & - & - & - & - & - & - & - \\
\hline & $10 / 95$ & $<0.2$ & $<0.2$ & $<0.2$ & $<0.2$ & $<0.2$ & $<0.2$ & $<0.2$ & $<0.2$ & $<0.2$ \\
\hline & $1 / 95$ & 0.7 & $<0.2$ & $<0.2$ & $<0.2$ & $<0.2$ & $<0.2$ & $<0.2$ & $<0.2$ & $<0.2$ \\
\hline & $4 / 95$ & 0.4 & $<0.2$ & $<0.2$ & $<0.2$ & $<0.2$ & $<0.2$ & $<0.2$ & $<0.2$ & $<0.2$ \\
\hline & $7 / 95$ & 0.5 & $<0.2$ & $<0.2$ & $<0.2$ & $<0.2$ & $<0.2$ & $<0.2$ & $<0.2$ & $<0.2$ \\
\hline & $10 / 95$ & 0.7 & $<0.2$ & $<0.2$ & $<0.2$ & $<0.2$ & $<0.2$ & $<0.2$ & $<0.2$ & $<0.2$ \\
\hline \multirow{11}{*}{$\begin{array}{l}\text { RWMC } \\
\text { Production } \\
\text { Well }\end{array}$} & $1 / 95$ & 4.1 & 0.5 & 0.6 & 1.7 & 0.2 & $<0.2$ & $<0.2$ & $<0.2$ & $<0.2$ \\
\hline & $2 / 95$ & 2.8 & 0.5 & $<0.5^{\mathrm{c}}$ & 1.7 & $<0.2$ & $<0.2$ & $<0.2$ & $<0.2$ & $<0.2$ \\
\hline & $3 / 95$ & 3.5 & 0.5 & 0.5 & 1.8 & $<0.2$ & $<0.2$ & $<0.2$ & $<0.2$ & $<0.2$ \\
\hline & $4 / 95$ & 3.8 & 0.5 & 0.5 & 1.9 & $<0.2$ & $<0.2$ & $<0.2$ & $<0.2$ & $<0.2$ \\
\hline & $5 / 95$ & 3.4 & 0.5 & 0.5 & 1.8 & $<0.2$ & $<0.2$ & $<0.2$ & $<0.2$ & $<0.2$ \\
\hline & $6 / 95$ & 3.7 & 0.6 & 0.5 & 1.9 & $<0.2$ & $<0.2$ & $<0.2$ & $<0.2$ & $<0.2$ \\
\hline & $7 / 95$ & 2.6 & 0.5 & 0.4 & 1.6 & $<0.2$ & $<0.2$ & $<0.2$ & $<0.2$ & $<0.2$ \\
\hline & $8 / 95$ & 3.7 & 0.5 & 0.5 & 1.8 & $<0.2$ & $<0.2$ & $<0.2$ & $<0.2$ & $<0.2$ \\
\hline & 9/95 & 4.0 & 0.5 & 0.6 & 1.9 & 0.2 & $<0.2$ & $<0.2$ & $<0.2$ & $<0.2$ \\
\hline & $10 / 95$ & 3.8 & 0.5 & 0.5 & 1.7 & 0.2 & $<0.2$ & $<0.2$ & $<0.2$ & $<0.2$ \\
\hline & $\begin{array}{l}11 / 95 \\
12 / 95^{d}\end{array}$ & 3.8 & 0.5 & 0.5 & 1.6 & $<0.2$ & $<0.2$ & $<0.2$ & $<0.2$ & $<0.2$ \\
\hline
\end{tabular}

a. Tests specific to pumps and instrumentation were conducted on Well 88 during Febuary 1992. The results of these tests are reported in a USGS report titled Purgeable Organic Compounds in the Ground Water at the Idaho National Engineering Laboratory, 1990-1992. ${ }^{19}$

b. No samples were collected.

c. The minimum detectable limit was raised due to laboratory contamination.

d. Samples were not analyzed due to the government furlough. 


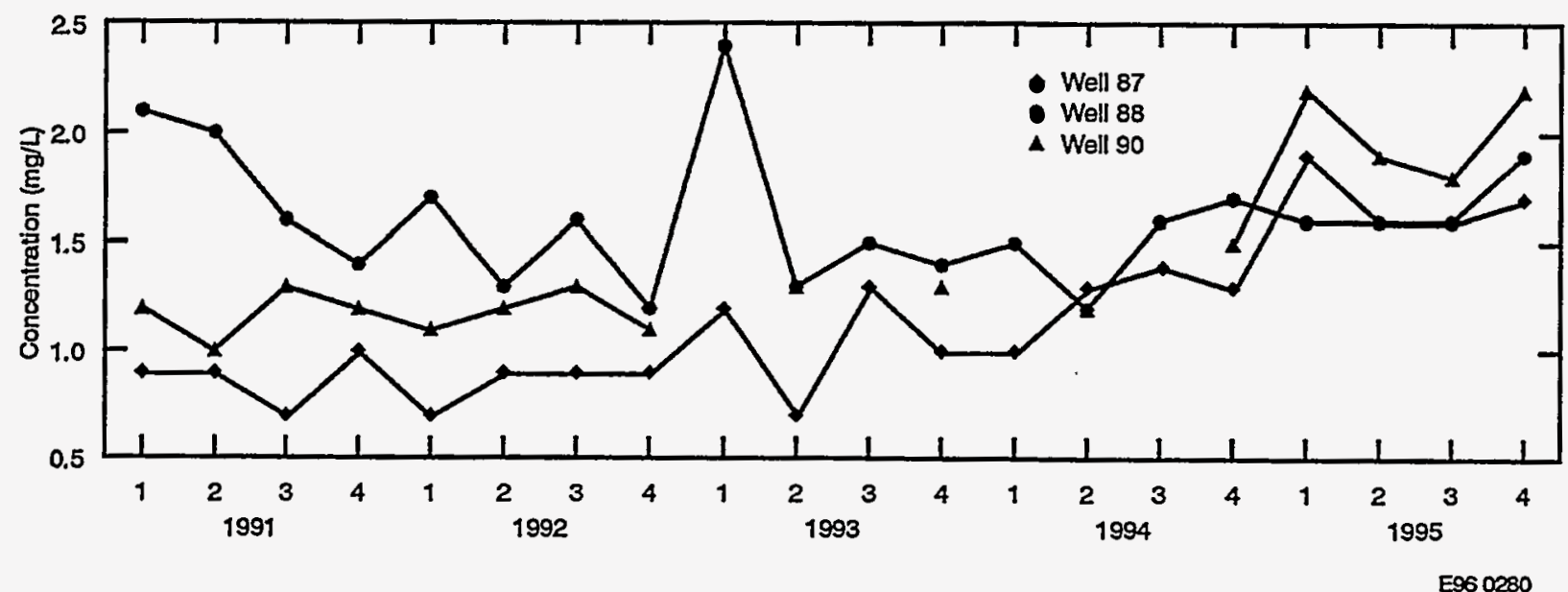

Figure 68. Carbon tetrachloride concentrations in Wells 87, 88, and 90.

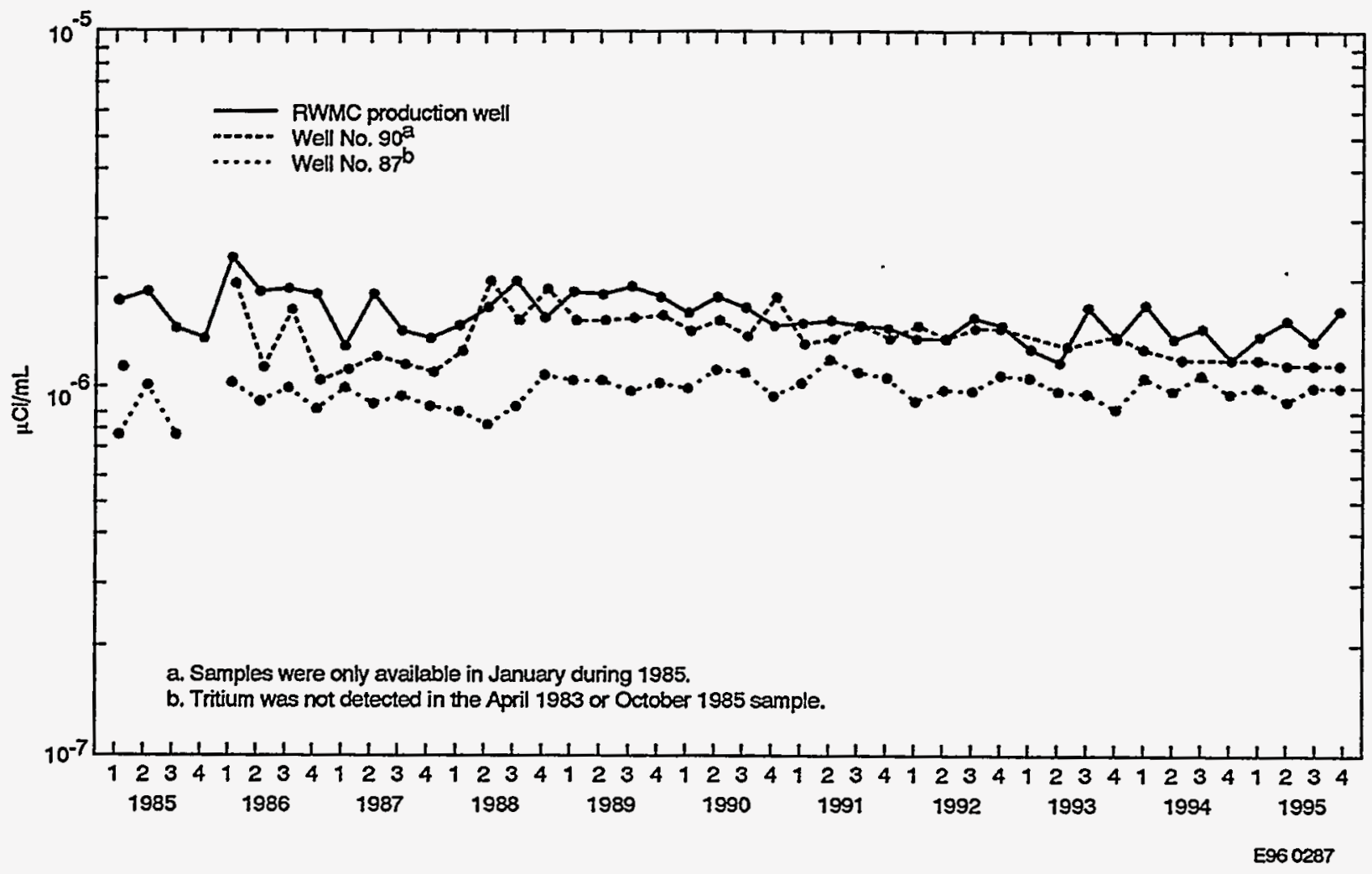

Figure 69. Tritium concentrations in RWMC wells. 
Table 8. Results of radiochemical analyses of RWMC subsurface water.

\begin{tabular}{|c|c|c|c|c|}
\hline Well & Month Sampled & Radionuclide $^{\mathrm{a}}$ & $\begin{array}{l}\text { Concentration } \\
\text { (E-6 } \mu \mathrm{Ci} / \mathrm{mL})\end{array}$ & Percentage of $D C G^{c}$ \\
\hline \multirow[t]{5}{*}{87} & January & $\mathrm{H}-3$ & $1 \pm 0.2$ & 0.05 \\
\hline & & Sr-90 & $2.7 \pm 0.8$ & 0.27 \\
\hline & April & $\mathrm{H}-3$ & $0.7 \pm 0.2$ & 0.04 \\
\hline & July & $\mathrm{H}-3$ & $1 \pm 0.2$ & 0.05 \\
\hline & October & $\mathrm{H}-3$ & $1 \pm 0.2$ & 0.05 \\
\hline \multirow[t]{4}{*}{$88^{\mathrm{d}}$} & January & - & - & - \\
\hline & April & - & - & - \\
\hline & July & 一 & 一 & - \\
\hline & October & - & 一 & - \\
\hline \multirow[t]{4}{*}{$89^{d}$} & January & - & - & - \\
\hline & April & - & - & - \\
\hline & July & - & - & - \\
\hline & October & - & 一 & - \\
\hline \multirow[t]{4}{*}{$90^{\mathrm{a}}$} & January & $\mathrm{H}-3$ & $1.3 \pm 0.2$ & 0.07 \\
\hline & April & $\mathrm{H}-3$ & $1.2 \pm 0.2$ & 0.06 \\
\hline & July & $\mathrm{H}-3$ & $1.2 \pm 0.2$ & 0.06 \\
\hline & October & $\mathrm{H}-3$ & $1.2 \pm 0.2$ & 0.06 \\
\hline \multirow[t]{4}{*}{$117^{d}$} & January & - & - & - \\
\hline & April & - & 一 & - \\
\hline & July & - & - & - \\
\hline & October & - & - & - \\
\hline \multirow[t]{4}{*}{$119^{d}$} & January & - & - & - \\
\hline & April & - & 一 & 一 \\
\hline & July & - & - & - \\
\hline & October & - & - & 一 \\
\hline \multirow[t]{4}{*}{$120^{\mathrm{d}}$} & January & - & - & - \\
\hline & April & - & - & - \\
\hline & July & - & - & - \\
\hline & October & - & - & - \\
\hline \multirow[t]{4}{*}{ RWMC Prod } & January & $\mathrm{H}-3$ & $1.5 \pm 0.2$ & 0.08 \\
\hline & April & $\mathrm{H}-3$ & $1.6 \pm 0.2$ & 0.08 \\
\hline & July & $\mathrm{H}-3$ & $1.4 \pm 0.2$ & 0.07 \\
\hline & October & $\mathrm{H}-3$ & $1.7 \pm 0.2$ & 0.09 \\
\hline
\end{tabular}

a. No radionuclides detected other than tritium. (See Tables B-1 and B-2 for limits of detection for other radionuclides.)

b. The \pm values are experimental random uncertainties in the counting measurement process and represent one standard deviation.

c. Derived Concentration Guide values for the public are based on the dose conversion factors provided in DOE Order 5400.5, "Radiation Protection of the Public and the Environment," February 8, 1990.

d. All radionuclides were below 3 times the analytical uncertainty. 


\section{REFERENCES}

1. K. L. Clawson, G. E. Start, and N. R. Ricks, Climatography of the Idaho National Engineering Laboratory, 2nd Edition, DOE/ID-12118, December 1989.

2. R. McBride, W. R. French, A. H. Dahl, and J. E. Detmer, Vegetation Types and Surface Soils of the Idaho National Engineering Laboratory Site, IDO-12084, 1978.

3. L. E. Adams, D. H. Janke, and P. T. Dickman, Annual Report-1978 Environmental Surveillance Report of the INEL Radioactive Waste Management Complex, TREE-1357, 1979.

4. C. R. Groves, The Ecology of Small Mammals on the Subsurface Disposal Area Idaho National Engineering Laboratory, M.S. Thesis, Idaho State University, 1981.

5. Department of Energy, "General Environmental Protection Program," DOE Order 5400.1, November 9, 1988.

6. Department of Energy, "Radioactive Waste Management," DOE Order 5820.2A, September 26, 1988.

7. O. D. Markham, K. W. Puphal, and T. D. Filer, "Plutonium and Americium Contamination Near a Transuranic Storage Area in Southeastern Idaho," Journal of Environmental Quality, 7, July/ September 1978, pp. 422-428.

8. EG\&G Idaho, Inc., Environmental Surveillance Handbook, "Radiological and Environmental Surveillance Program Plan for Waste Management Facilities," July 1994.

9. Department of Energy, "Radiation Protection of the Public and the Environment," DOE Order 5400.5, January 7, 1993.

10. EG\&G Idaho, Inc., Modifications to RWMC Air Monitoring Activities Recommended by the Monitoring Activities Review, August 23, 1983.

11. EG\&G Idaho, Inc., 1983a, Modifications to RWMC Soil Monitoring Activities Recommended by the Monitoring Activities Review, August 23, 1983.

12. EG\&G Idaho, Inc., 1989, Monitoring Activities Review of the Environmental Monitoring Program, EGG-ESQ-8406.

13. W. J. Arthur and O. D. Markham, Small Mammal Soil Burrowing as a Radionuclide Transport Vector at a Radioactive Waste Disposal Area in Southeastern Idaho, 1982.

14. W. J. Arthur, "Radionuclide Concentrations in Vegetation at a Solid Radioactive Disposal Area in Southeastern Idaho," Journal of Environmental Quality, 11, 1982, pp. 394-398.

15. EG\&G Idaho, Inc., 1983d, Environmental Monitoring for the Waste Experimental Reduction Facility at the Idaho National Engineering Laboratory, RHB-132-83.

16. EG\&G Idaho, Inc., Annual Report-1991 Environmental Surveillance for Waste Management Facilities at the Idaho National Engineering Laboratory, EGG-2679 (91), August 1992. 
17. EG\&G Idaho, Inc., RWMC Project Directives, PD-RS-6.1, "Radiation and Contamination Control," January 10, 1995.

18. B. R. Orr and L. D. Cecil, Hydrologic Conditions and Distribution of Selected Chemical Constituents in Water, Snake River Plain Aquifer, Idaho National Engineering Laboratory, Idaho, 1986 to 1988, U.S. Geological Survey Water-Resources Investigations Report 91-4047, 1991.

19. L. J. Mann and L. L. Knobel, Purgeable Organic Compounds in Ground Water at the Idaho National Engineering Laboratory, Idaho, U.S. Geological Survey Open-File Report 87-776 (DOE/D-22074), p 23, 1987.

20. Lockheed Martin Idaho Technologies Company, Calendar Year 1995 Compliance Monitoring Report, INEL-95/0255(95), August 1996.

21. Environmental Science and Research Foundation, Idaho National Engineering Laboratory Site Environmental Report for Calendar Year 1995, DOE/ID-12082(95), July 1996. 
Appendix A

Quality Assurance 
A-2

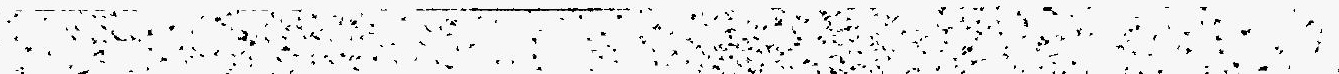




\section{Appendix A}

\section{Quality Assurance}

\section{INTRODUCTION}

The Quality Assurance (QA) Program helps maintain an adequate level of data reliability and provides for measurement of reliability in order for the program can determine if it can accept the data. The QA Program also indicates deficiencies in the sampling, analyzing, and reporting processes so that corrective actions can be taken.

The Radiological Environmental Surveillance Program (RESP) QA Program is implemented in the RESP procedures and program plan, which specifically address the following:

- Program objectives, basis, design, and description

- Organizational structure and responsibilities of managerial and program personnel

- Configuration-controlled procedures, which describe all quality-affecting aspects of monitoring activities, including sample custody, calibration of equipment, and preventive maintenance

- Maintenance pertaining to monitoring activities, such as logbooks, data sheets, and calibration records

- Data reduction, analysis, and independent validation procedures

- Quality control (QC) samples such as field replicates, spiked samples, known standards, and blanks used to assess the accuracy and precision of monitoring data and to identify specific processes (i.e., in field operations or laboratory performance) that are adversely affecting data quality

- Internal and independent audits.

An independent reviewer validates and verifies RESP data in accordance with EMSP 15.1. ${ }^{2}$ The validation and verification review determines if the precision, accuracy, representativeness, comparability, and completeness of the data meet the program's requirements. This review covers field, laboratory, and data management operations. Data that meet the requirements may be reported, without qualifications or limitations, as representative of the amounts or concentrations of radioactive materials in the environment.

\section{RESP FIELD QUALITY ASSURANCE AND QUALITY CONTROL PROGRAM}

Quality control checks on RESP field operations include internal and independent reviews of the procedures, conformance of field operations to procedures, and external reviews (referred to as monitoring activity reviews) of the overall program. These reviews provide information required to evaluate the representativeness and comparability of the RESP data. The adequacy of field operations, as they affect the precision and accuracy of the RESP data, are evaluated with QC samples. Field replicates help identify potential problems with field operations. Statistically significant differences in field blanks indicate (but do not confirm) that the sampling program design or execution is insufficient to produce data that meet the RESP's objectives for precision and accuracy. Discrepancies in results of QC samples are investigated and corrective actions are initiated accordingly to ensure that the RESP's objectives are met. 


\section{RESP QA AND QC PROGRAM FOR LABORATORY ANALYSES}

RESP submits QC samples such as field replicates, spiked samples, known standards, and blanks to the program's laboratories to assess the accuracy and precision of monitoring data. Quality control samples also help identify specific processes (i.e., in field operations or laboratory performance) that adversely affect data quality.

\section{Laboratory Participation In Quality Control Programs}

The Lockheed Martin Idaho Technologies Company Analytical Laboratories department analyzes all of RESP's samples as specified in the statements of work. The Lockheed Martin Idaho laboratories participate in several QA programs, which verify all of the methods used to analyze environmental samples. These programs include the DOE/Environmental Measurements Laboratory (EML) QA Program, the EPA-Environmental Measurements Systems Laboratory (EMSL) QA Program, and several Idaho National Engineering Laboratory (INEL) customer QA programs. The following sections briefly describe these programs.

\section{DOE-EML Quality Assurance Program}

DOE-EML administers the DOE-EML QA Program. Laboratories engaged in the radiochemical analysis of environmental samples for DOE and DOE contractors are required to participate in this program. Samples containing between 0.01 and $100 \mathrm{~Bq} /$ reporting unit of alpha-, beta- or gamma-emitting radionuclides in water, soil, air filters, tissue, or vegetation matrices are provided to the laboratory twice a year. The accepted true value of the radionuclide content of the samples is determined by multiple analyses by EML. Analytical Laboratories analyze the samples using established procedures and any special preparation or analysis suggestsed by EML. The program sponsor controls data handling and sample results and provides Lockheed Martin Idaho line supervision a comparison of the results obtained from the participating laboratories.

\section{EPA Quality Assurance Program}

The U. S. Environmental Protection Agency (EPA) Environmental Measurement Systems Laboratory (EMSL) administers the EPA QA Program on a national scale. Many laboratories engaged in the radiochemical analysis of environmental samples participate in this program. Samples containing between 0.02 and $100 \mathrm{pCi}$ of alpha-, beta-, or gamma-emitting radionuclides in water or air filters are provided throughout the year. Analytical laboratories analyzes the samples using established procedures, and any suggested special preparation or analysis provided by the EPA. The program sponsor controls data han-

dling and sample results and provides Lockheed Martin Idaho line supervision a comparison of the results obtained by participating laboratories.

\section{RESP and Other Laboratory Quality Assurance Program}

RESP conducts the QA Program that support the Radioactive Waste Management Complex, the Decontamination and Dismantlement Program, and others. Blind QC samples are prepared to RESP general specifications and are submitted to the laboratory with field samples. The QC samples contain radionuclides that might be present, including a variety of alpha-, beta-, and gamma-emitting radionuclides. These radionuclides are added to water, soil, biotic, and air filter matrices to produce samples with appropriate concentrations to test the laboratory's accuracy and sensitivity. RESP controls and reports the data handling and QC sample results. 
The results of QC sample analyses and laboratory performance during calendar year 1995 (CY-1995) are presented in the Radiation Measurements Laboratory Quality Assurance and Quality Control Report for 1994/19953 for both EML and EMSL results. With few exceptions, the laboratories met the performance objectives specified by the EML and EMSL. The EML results for the laboratory are also available in the INEL Site Environmental Report for Calendar Year 1995. ${ }^{4}$

Two levels of activity are necessary to check both the stated detection limits and to determine the accuracy and precision with which larger activities can be measured. The lower level consists of activities from about 1.5 to 5 times the stated absolute detection limits to maximize the influence of backgrounds, blanks, and interferences from the sample on the net activity being measured. Specifically, no attempt is made to verify stated detection limits by analysis of blanks due to the large statistical uncertainties of net results obtained from subtracting blanks from samples that are also blank. The higher level consists of sufficient activity to permit relative standard deviations of 1 to $5 \%$ to minimize statistical uncertainties and make clearer the precision and accuracy being obtained. The RESP detects extremely low environmental concentrations in sample media; therefore, it is important that RESP QC sample sets include blanks for detecting cross-contamination problems in the laboratory. If cross-contamination occurs, the validity of the data generated in the same analytical batch is questionable. In general, these data are impossible to recover because a reliable relationship between the observed and true values does not exist.

\section{RESP QC SAMPLE RESULTS FOR FY 95}

During 1995, RESP submitted spiked vegetation samples and spiked air filters to the laboratory. The results for radiochemical analyses of spiked vegetation samples are presented in Table A-1. The analyses of vegetation samples, with the exception of the analysis for Sr-90 met the RESP objective for accuracy in accordance with the RESP Program Plan. Sr-90 results were invalidated due to evidence of cross-contamination during analysis. The results of these analyses are presented in Table A-2. The results for the agreement ratio do not show acceptable agreement for Am-241 or Pu-239. The results for Sr-90 and Pu-238 show acceptable agreement.

\section{RESP CALENDAR YEAR 1995 QA AND DATA VALIDATION SUMMARY}

RESP staff and the RESP's independent data reviewer, reviewed the CY-1995 QC sample data for all of the QC sample programs (as summarized by the RML in INEL-96/092', and in letters MWH-14-95, MWH-16-95, MWH-01-96). With the exception of the radiochemical analyses of second quarter air samples, and Sr-90 analysis for vegetation, the data met the RESP's objectives for data quality. A set of QC samples ( 2 spiked samples and a blank) was submitted with the second quarter ambient air samples. The reported results indicated the presence of Sr-90 and transuranic radionuclides in the blank. This evidence of cross-contamination was considered sufficient reason to invalidate the data set. The data set could not be corrected and rendered suitable for reporting because of the unpredictable nature of cross-contamination. A set of QC samples were also submitted with annual vegetation samples ( 2 spiked samples and a blank). Sr-90 was detected in the blank and Sr-90 results were also invalidated as a result of evidence of cross-contamination. The remaining vegetation analyses met the objectives for data quality. 
Table A-1. Results of radiochemical analysis of spiked vegetation submitted by RESP in 1995.

\begin{tabular}{|c|c|c|c|c|c|c|}
\hline QC Sample & Nuclide & $\begin{array}{c}\text { Spike Conc. } \\
(\mu \mathrm{Ci} / \mathrm{g})\end{array}$ & $\begin{array}{l}\text { Spike } \\
\text { Uncert. } \\
(\mu \mathrm{Ci} / \mathrm{g})\end{array}$ & $\begin{array}{c}\text { Lab Conc. } \\
(\mu \mathrm{Ci} / \mathrm{g})\end{array}$ & $\begin{array}{l}\text { Lab Uncert. } \\
\qquad(\mu \mathrm{Ci} / \mathrm{g})\end{array}$ & $\begin{array}{c}\text { Agreement } \\
\text { Ratio }\end{array}$ \\
\hline 95R06V01 & $\mathrm{Pu}-239$ & $2.40 \mathrm{E}-08$ & $5.00 \mathrm{E}-10$ & 2.30E-08 & $3.00 \mathrm{E}-09$ & 0.96 \\
\hline 95R06V01 & $\mathrm{Pu}-238$ & 2.21E-08 & $4.00 \mathrm{E}-10$ & 2.00E-08 & 2.00E-09 & 0.9 \\
\hline 95R06V01 & Am-241 & $1.47 \mathrm{E}-08$ & $3.00 \mathrm{E}-10$ & $1.50 \mathrm{E}-08$ & 2.00E-09 & 1.02 \\
\hline 95R06V01 & Sr-90 & $9.60 \mathrm{E}-08$ & 2.00E-09 & $7.80 \mathrm{E}-10$ & $7.00 \mathrm{E}-09$ & 0.81 \\
\hline $95 \mathrm{R} 06 \mathrm{~V} 02^{\mathrm{a}}$ & $\mathrm{Pu}-239$ & $0.00 \mathrm{E}-00$ & $0.00 \mathrm{E}-00$ & $\mathrm{BDL}^{\mathrm{b}}$ & $N A^{c}$ & NA \\
\hline 95R06V02 & $\mathrm{Pu}-238$ & $0.00 \mathrm{E}-00$ & $0.00 \mathrm{E}-00$ & $\mathrm{BDL}$ & NA & NA \\
\hline 95R06V02 & Am-241 & $0.00 \mathrm{E}-00$ & $0.00 \mathrm{E}-00$ & $\mathrm{BDL}$ & $\mathrm{NA}$ & NA \\
\hline 95R06V02 & Sr-90 & $0.00 \mathrm{E}-00$ & $0.00 \mathrm{E}-00$ & $2.90 \mathrm{E}-08$ & $6.00 \mathrm{E}-09$ & NA \\
\hline 95R06V03 & Pu-239 & 8.79E-09 & $1.80 \mathrm{E}-10$ & 8.00E-09 & $1.20 \mathrm{E}-09$ & 0.91 \\
\hline 95R06V03 & $\mathrm{Pu}-238$ & 1.08E-08 & $2.00 \mathrm{E}-10$ & $1.00 \mathrm{E}-08$ & $1.40 \mathrm{E}-09$ & 0.92 \\
\hline 95R06V03 & Am-241 & 8.62E-09 & $1.80 \mathrm{E}-09$ & 2.00E-09 & $3.00 \mathrm{E}-09$ & $0.23^{d}$ \\
\hline 95R06V03 & Sr-90 & 4.69E-08 & 1.00E-09 & 7.10E-08 & 7.00E-09 & 1.51 \\
\hline \multicolumn{7}{|c|}{$\begin{array}{ll}\text { a. } & \text { Blank sample. } \\
\text { b. } & \text { Result reported below detection limit. } \\
\text { c. Not applicable. } \\
\text { d. The laboratory reported a low yield for this sample. }\end{array}$} \\
\hline
\end{tabular}


Table A-2. Results of radiochemical analysis of spiked air filters submitted by RESP in 1995 .

\begin{tabular}{|c|c|c|c|c|c|c|}
\hline QC Sample & Nuclide & $\begin{array}{l}\text { Spike Conc. } \\
(\mu \mathrm{Ci} / \mathrm{cc})\end{array}$ & $\begin{array}{c}\text { Spike } \\
\text { Uncert. } \\
(\mu \mathrm{Ci} / c c)\end{array}$ & $\begin{array}{l}\text { Lab Conc. } \\
(\mu \mathrm{Ci} / \mathrm{cc})\end{array}$ & $\begin{array}{l}\text { Lab Uncert. } \\
\qquad(\mu \mathrm{Ci} / \mathrm{cc})\end{array}$ & $\begin{array}{c}\text { Agreement } \\
\text { Ratio }\end{array}$ \\
\hline 16 (low) & Sr-90 & $6.84 \mathrm{E}-16$ & $1.68 \mathrm{E}-14$ & $9.60 \mathrm{E}-16$ & $4.00 \mathrm{E}-14$ & 0.841 \\
\hline 17 (high) & & 6.77E-13 & $1.81 \mathrm{E}-17$ & $5.70 \mathrm{E}-13$ & $1.00 \mathrm{E}-16$ & 1.404 \\
\hline 18 (blank) & & $0.00 E+00$ & $0.00 \mathrm{E}+00$ & 4.10E-16 & $6.00 \mathrm{E}-17$ & \\
\hline 16 (low) & Am-241 & $1.95 \mathrm{E}-16$ & $3.66 \mathrm{E}-18$ & 4.10E-16 & $5.00 \mathrm{E}-17$ & 2.103 \\
\hline 17 (high) & & $5.28 \mathrm{E}-13$ & $7.76 \mathrm{E}-15$ & - $^{a}$ & - & \\
\hline 18 (blank) & & $0.00 \mathrm{E}+00$ & $0.00 E+00$ & $3.50 \mathrm{E}-16$ & $5.00 \mathrm{E}-17$ & \\
\hline 16 (low) & $\mathrm{Pu}-238$ & $1.99 \mathrm{E}-16$ & $2.80 \mathrm{E}-15$ & $3.00 \mathrm{E}-16$ & $4.00 \mathrm{E}-17$ & \\
\hline 17 (high) & & $2.17 \mathrm{E}-13$ & $3.02 \mathrm{E}-18$ & 一 & - & 1.507 \\
\hline 18 (blank) & & $0.00 \mathrm{E}+00$ & $0.00 \mathrm{E}+00$ & $1.40 \mathrm{E}-16$ & $2.00 \mathrm{E}-17$ & \\
\hline 16 (low) & $\mathrm{Pu}-239$ & $2.01 E-16$ & $4.95 \mathrm{E}-18$ & $4.30 \mathrm{E}-16$ & $5.00 \mathrm{E}-17$ & 2.137 \\
\hline 17 (high) & & $9.91 \mathrm{E}-13$ & 2.33E-14 & - & - & \\
\hline 18 (blank) & & $0.00 \mathrm{E}+00$ & $0.00 \mathrm{E}+00$ & $4.30 \mathrm{E}-16$ & $6.00 \mathrm{E}-17$ & \\
\hline
\end{tabular}


A-8

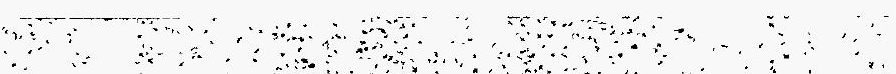




\section{REFERENCES}

1. Environmental Surveillance Handbook, Lockheed Martin Idaho Technologies Company, current issue.

2. EMSP-15.1, "Validating and controlling Data Originating from EM Sampling Efforts," Environmental Monitoring Administration Manual, Lockheed Martin Idaho Technologies Company, March 4, 1994.

3. Radiation Measurements Laboratory, Radiation Measurements Laboratory Quality Assurance and Quality Control Report for 1994/1995, INEL-96/096, Draft June 1996.

4. Environmental Science and Research Foundation, Idaho National Engineering Laboratory Site Environmental Report for Calendar Year 1995, DOE/ID-12082(95), July 1996. 


\section{Appendix B}

\section{Detection Limits}

B-1 
B-2 


\section{Appendix B}

\section{Detection Limits}

\section{RADIOCHEMICAL ANALYSIS DETECTION LIMITS}

Tables B-1, B-2 and B-3 list approximate detection limits of present methods used to analyze the samples discussed in this report. These limits are based on sample sizes and forms as described in this report. Actual detection limits may vary depending upon background, yield, counting time, and sample volume.

The detection limits given in Table B-1 in terms of activity per unit weight or volume are derived from the total activities in microcuries $(\mu \mathrm{Ci})$ that must be present in the sample aliquot. The detection limits are calculated under the following conditions: a counting time of 1000 minutes, a counting efficiency of about $25 \%$, a chemical yield of about $80 \%$, clean detector and reagent blanks that give not more than about 5 counts in 1,000 minutes in any given energy interval, and the calculation performed according to the definition of detection limits given by L. A. Currie.

detection limit $=\frac{2.71+4.66 B^{1 / 2}}{t \times E \times Y \times 2.22 E+6} \mu C i$

where

$\mathrm{B}=$ the total background and blank correction

$\mathrm{t}=$ the counting time in minutes

$\mathrm{E}=$ the counting efficiency as a fraction

$\mathrm{Y}=$ the chemical yield as a fraction

$2.22 \mathrm{E}+6=$ the $\mathrm{dpm} / \mu \mathrm{Ci}$.

These absolute detection limits, in terms of total microcuries per sample, are approximately $3 \mathrm{E}-6$ for Sr-90 and approximately 3 E-8 for all alpha-emitting nuclides. To determine the detection limits as activity concentration, as given in Table B-1, the absolute detection limits must be divided by the sample size taken for analysis. On samples, the activity found is divided by the actual sample size analyzed or reported in terms of total activity per sample. 
Table B-1. RESP samples for radiochemical analysis.

\begin{tabular}{|c|c|c|c|c|}
\hline Media & Sample description & Method of treatment & \multicolumn{2}{|c|}{$\begin{array}{l}\text { Detection limits } \\
(\mu \mathrm{Ci} / \mathrm{g} \text { or } \mathrm{mL})\end{array}$} \\
\hline Air & $\begin{array}{l}\text { Sampled } \\
\text { approximately at } \\
4 \text { cfm for } 2 \text { weeks on } \\
\text { Versapor } 1,200 \text { filters, } \\
6 \text { filters per quarter } \\
\text { for a total of } \\
\sim 1.7 \mathrm{E}+10 \text { cc of air. }\end{array}$ & $\begin{array}{l}\text { Dry ash, dissolve and } \\
\text { analyze the total sample } \\
\text { of } 6 \text { filters. }\end{array}$ & $\begin{array}{l}\text { Sr-90 } \\
\mathrm{Pu}-238 \\
\mathrm{Pu}-239 \\
\text { Am-241 }\end{array}$ & $\begin{array}{l}3.5 \mathrm{E}-17 \\
2 \mathrm{E}-18 \\
2 \mathrm{E}-18 \\
2 \mathrm{E}-18\end{array}$ \\
\hline Water & $\begin{array}{l}\text { 4-L collapsible } \\
\text { polyethylene } \\
\text { container containing } \\
25 \mathrm{~mL} \text { of conc. } \\
\mathrm{HNO}_{3} \text { and } 2 \\
\text { Whatman ashless } \\
\text { filter tablets for } \\
4,000 \mathrm{~mL} \text { water. }\end{array}$ & $\begin{array}{l}\text { Separate and dissolve } \\
\text { paper pulp, reconstitute } \\
\text { sample, and boil down to } \\
100 \mathrm{~mL} \text {. Analyze } \\
1 / 2 \text { sample or } 2-\mathrm{L} \\
\text { equivalent. }\end{array}$ & $\begin{array}{l}\mathrm{Sr}-90 \\
\mathrm{Pu}-238 \\
\mathrm{Pu}-239 \\
\mathrm{Am}-241\end{array}$ & $\begin{array}{l}3 \mathrm{E}-10 \\
2 \mathrm{E}-11 \\
2 \mathrm{E}-11 \\
2 \mathrm{E}-11\end{array}$ \\
\hline Soil & $\begin{array}{l}\text { At least } 25 \mathrm{~g} \text { in } \\
\text { appropriate container. } \\
\text { Larger quantities are } \\
\text { permissible if } \\
\text { convenient. }\end{array}$ & Analyze 10 -g sample. & $\begin{array}{l}\mathrm{Sr}-90 \\
\mathrm{Pu}-238 \\
\mathrm{Pu}-239 \\
\mathrm{Am}-241\end{array}$ & $\begin{array}{l}6 \text { E-8 } \\
3 \text { E-9 } \\
3 \text { E-9 } \\
3 \text { E-9 }\end{array}$ \\
\hline Vegetation & $\begin{array}{l}\text { 16-oz squat jar filled } \\
\text { to rim below threads } \\
\text { (avg wt } 150 \mathrm{~g} \text { ). }\end{array}$ & $\begin{array}{l}\text { Dry ash and dissolve the } \\
\text { total sample completely. } \\
\text { Analyze the equivalent } \\
\text { of } 50 \mathrm{~g} \text { of original } \\
\text { sample. }\end{array}$ & $\begin{array}{l}\mathrm{Sr}-90 \\
\mathrm{Pu}-238 \\
\mathrm{Pu}-239 \\
\mathrm{Am}-241\end{array}$ & $\begin{array}{l}1.2 \mathrm{E}-8 \\
6 \mathrm{E}-10 \\
6 \mathrm{E}-10 \\
6 \mathrm{E}-10\end{array}$ \\
\hline $\begin{array}{l}\text { Animal } \\
\text { Tissue }\end{array}$ & $\begin{array}{l}\text { 16-oz squat jar } \\
\text { containing } 10 \text { dried } \\
\text { deer mice, or } 1 \text { dried } \\
\text { ground squirrel (avg } \\
\text { wts: mice, } 170 \mathrm{~g} \text {; } \\
\text { squirrel, } 100 \mathrm{~g} \text { ). }\end{array}$ & $\begin{array}{l}\text { Dry ash, dissolve, and } \\
\text { analyze the equivalent of } \\
50 \mathrm{~g} \text { of the original } \\
\text { sample. }\end{array}$ & $\begin{array}{l}\mathrm{Sr}-90 \\
\mathrm{Pu}-238 \\
\mathrm{Pu}-239 \\
\mathrm{Am}-241\end{array}$ & $\begin{array}{l}1.2 \mathrm{E}-8 \\
6 \mathrm{E}-10 \\
6 \mathrm{E}-10 \\
6 \mathrm{E}-10\end{array}$ \\
\hline
\end{tabular}


Table B-2. RESP air, water, and soil samples for gamma spectrometry.

\begin{tabular}{|c|c|c|c|c|c|c|c|c|}
\hline \multirow[b]{2}{*}{ Radionuclides } & \multicolumn{2}{|c|}{ Air filters } & \multicolumn{2}{|c|}{ Water filtrate } & \multicolumn{2}{|c|}{ Water insoluble } & \multicolumn{2}{|c|}{ Soils } \\
\hline & $\begin{array}{c}10^{-9} \\
\mathrm{pCi} / \mathrm{mL} \\
\end{array}$ & $\begin{array}{l}\text { Total } \\
\text { pCi }\end{array}$ & $\begin{array}{c}10^{-2} \\
\mathrm{pCi} / \mathrm{mL} \\
\end{array}$ & $\begin{array}{c}\text { Total } \\
\mathrm{pCi} \\
\end{array}$ & $\begin{array}{c}10^{-4} \\
\mathrm{pCi} / \mathrm{mL}\end{array}$ & $\begin{array}{c}\text { Total } \\
\mathrm{pCi}\end{array}$ & $\mathrm{pCi} / \mathrm{g}$ & $\begin{array}{r}\text { Total } \\
\mathrm{pCi}\end{array}$ \\
\hline $\begin{array}{l}\text { Sc-46 } \\
\text { Cr-51 } \\
\text { Mn-54 } \\
\text { Co-58 }\end{array}$ & $\begin{array}{l}1 \\
5 \\
0.5 \\
0.5\end{array}$ & $\begin{array}{l}6 \\
3 \\
3 \\
3\end{array}$ & $\begin{array}{l}0.2 \\
1.1 \\
0.5 \\
0.09\end{array}$ & $\begin{array}{c}8 \\
44 \\
20 \\
3.6\end{array}$ & $\begin{array}{r}5 \\
20 \\
3 \\
4\end{array}$ & $\begin{array}{l}2 \\
8 \\
1.2 \\
1.6\end{array}$ & $\begin{array}{l}0.19 \\
0.5 \\
0.1 \\
0.1\end{array}$ & $\begin{array}{r}120 \\
300 \\
60 \\
60\end{array}$ \\
\hline $\begin{array}{l}\mathrm{Fe}-59 \\
\mathrm{Co}-60 \\
\mathrm{Zn}-65 \\
\mathrm{Nb}-94 \\
\mathrm{Nb}-95\end{array}$ & $\begin{array}{l}0.9 \\
0.8 \\
1 \\
0.5 \\
0.5\end{array}$ & $\begin{array}{l}5.4 \\
4.8 \\
6 \\
3 \\
3\end{array}$ & $\begin{array}{l}1.5 \\
0.8 \\
0.5 \\
0.15 \\
0.11\end{array}$ & $\begin{array}{r}60 \\
32 \\
20 \\
6 \\
4.4\end{array}$ & $\begin{array}{r}7 \\
6 \\
15 \\
4 \\
80\end{array}$ & $\begin{array}{l}2.8 \\
2.4 \\
6 \\
1.6 \\
32\end{array}$ & $\begin{array}{l}0.11 \\
0.2 \\
0.2 \\
0.1 \\
0.1\end{array}$ & $\begin{array}{r}60 \\
120 \\
120 \\
60 \\
60\end{array}$ \\
\hline $\begin{array}{l}\mathrm{Zr}-95 \\
\mathrm{Ru}-103 \\
\mathrm{Ru}-106 \\
\mathrm{Ag}-110 \mathrm{~m} \\
\mathrm{Sb}-124\end{array}$ & $\begin{array}{l}0.8 \\
0.7 \\
5 \\
0.5 \\
0.5\end{array}$ & $\begin{array}{c}4.8 \\
4.2 \\
30 \\
3 \\
3\end{array}$ & $\begin{array}{l}0.3 \\
0.16 \\
0.12 \\
0.15 \\
0.13\end{array}$ & $\begin{array}{l}8 \\
6.4 \\
4.8 \\
6 \\
5.2\end{array}$ & $\begin{array}{r}7 \\
4 \\
40 \\
5 \\
5\end{array}$ & $\begin{array}{c}2.8 \\
1.6 \\
1.6 \\
20 \\
2\end{array}$ & $\begin{array}{l}0.11 \\
0.1 \\
0.5 \\
0.1 \\
0.1\end{array}$ & $\begin{array}{r}60 \\
60 \\
300 \\
60 \\
60\end{array}$ \\
\hline $\begin{array}{l}\text { Sb-125 } \\
\text { Cs-134 } \\
\text { Cs-137 } \\
\text { Ce-141 } \\
\text { Ce-144 }\end{array}$ & $\begin{array}{l}1.5 \\
0.6 \\
0.8 \\
0.9 \\
5\end{array}$ & $\begin{array}{l}9 \\
3.6 \\
4.8 \\
5.4 \\
30\end{array}$ & $\begin{array}{l}0.3 \\
0.09 \\
0.3 \\
0.3 \\
1.0\end{array}$ & $\begin{array}{l}12 \\
3.6 \\
12 \\
12 \\
40\end{array}$ & $\begin{array}{r}15 \\
4 \\
20 \\
6 \\
20\end{array}$ & $\begin{array}{l}6 \\
1.6 \\
8 \\
2.4 \\
8\end{array}$ & $\begin{array}{l}0.2 \\
0.1 \\
0.1 \\
0.1 \\
0.4\end{array}$ & $\begin{array}{r}120 \\
60 \\
60 \\
60 \\
240\end{array}$ \\
\hline $\begin{array}{l}\text { Eu-152 } \\
\text { Eu-154 } \\
\text { Eu-155 } \\
\text { Hf-181 } \\
\text { Ta-182 }\end{array}$ & $\begin{array}{l}2 \\
2 \\
2 \\
0.6 \\
2\end{array}$ & $\begin{array}{l}12 \\
12 \\
12 \\
3.6 \\
12\end{array}$ & $\begin{array}{l}0.5 \\
0.3 \\
0.8 \\
0.12 \\
0.5\end{array}$ & $\begin{array}{l}20 \\
12 \\
32 \\
4.8 \\
20\end{array}$ & $\begin{array}{r}15 \\
15 \\
10 \\
6 \\
20\end{array}$ & $\begin{array}{l}6 \\
6 \\
4 \\
2.4 \\
8\end{array}$ & $\begin{array}{l}0.2 \\
0.3 \\
0.3 \\
0.1 \\
0.4\end{array}$ & $\begin{array}{r}120 \\
180 \\
180 \\
60 \\
240\end{array}$ \\
\hline $\begin{array}{l}\text { Hg-203 } \\
\text { Am-241 } \\
\text { Gross Beta } \\
\text { Gross Alpha }\end{array}$ & $\begin{array}{l}0.5 \\
4 \\
9.5 \\
3.3\end{array}$ & $\begin{array}{r}3 \\
24\end{array}$ & $\begin{array}{l}0.15 \\
1.5\end{array}$ & $\begin{array}{r}6 \\
60\end{array}$ & $\begin{array}{r}2 \\
40\end{array}$ & $\begin{array}{l}0.8 \\
16\end{array}$ & $\begin{array}{l}0.1 \\
1.2\end{array}$ & $\begin{array}{r}60 \\
700\end{array}$ \\
\hline
\end{tabular}


Table B-3. RESP biotic samples for gamma spectrometry.

\begin{tabular}{|c|c|c|c|c|}
\hline \multirow[b]{2}{*}{ Radionuclides } & \multicolumn{2}{|c|}{ Small mammals } & \multicolumn{2}{|c|}{ Vegetation } \\
\hline & $\mathrm{pCi} / \mathrm{g}$ & $\begin{array}{l}\text { Total } \\
\text { pCi }\end{array}$ & $\mathrm{pCi} / \mathrm{g}$ & $\begin{array}{l}\text { Total } \\
\text { pCi }\end{array}$ \\
\hline Sc-46 & 0.2 & 12 & 0.07 & 12 \\
\hline $\mathrm{Cr}-51$ & 1.4 & 84 & 0.4 & 67 \\
\hline $\mathrm{Mn}-54$ & 0.18 & 11 & 0.05 & 8.4 \\
\hline $\mathrm{Co}-58$ & 0.3 & 18 & 0.05 & 8.4 \\
\hline $\mathrm{Fe}-59$ & 0.6 & 36 & 0.08 & 14 \\
\hline Co- 60 & 1 & 60 & 0.1 & 17 \\
\hline $\mathrm{Zn}-65$ & 0.7 & 42 & 0.13 & 22 \\
\hline $\mathrm{Nb}-94$ & 0.2 & 12 & 0.05 & 8.4 \\
\hline $\mathrm{Nb}-95$ & 0.2 & 12 & 0.04 & 6.7 \\
\hline $\mathrm{Zr}-95$ & 0.3 & 18 & 0.07 & 12 \\
\hline Ru-103 & 0.2 & 120 & 0.04 & 6.7 \\
\hline Ru-106 & 2 & 12 & 0.5 & 84 \\
\hline $\mathrm{Ag}-110 \mathrm{~m}$ & 0.2 & 12 & 0.05 & 8.4 \\
\hline Sb-124 & 0.2 & 12 & 0.04 & 6.7 \\
\hline $\mathrm{Sb}-125$ & 0.7 & 42 & 0.11 & 18 \\
\hline Cs-134 & 0.3 & 18 & 0.04 & 6.7 \\
\hline Cs-137 & 1.3 & 78 & 0.13 & 22 \\
\hline Ce-141 & 0.2 & 12 & 0.05 & 8.4 \\
\hline $\mathrm{Ce}-144$ & 1.1 & 66 & 0.16 & 27 \\
\hline Eu-152 & 0.6 & 36 & 0.1 & 17 \\
\hline Eu-154 & 0.7 & 42 & 0.15 & 25 \\
\hline Eu-155 & 0.6 & 36 & 0.1 & 17 \\
\hline Hf-181 & 0.2 & 12 & 0.04 & 6.7 \\
\hline $\mathrm{Ta}-182$ & 1.1 & 66 & 0.3 & 50 \\
\hline $\mathrm{Hg}-203$ & 0.16 & 96 & 0.05 & 8.4 \\
\hline Am-241 & 2 & 120 & 0.3 & 50 \\
\hline
\end{tabular}




\section{GAMMA SPECTROMETRIC ANALYSIS DETECTION LIMITS}

Tables B-2 and B-3 give absolute detection limits in the right-hand column for each sample type. The absolute detection limits are the total activities that should be present in the sample aliquot taken for analysis. These activities should be detected under the counting conditions described and calculated according to the definition of L. A. Currie. This definition is as follows:

detection limit $=\frac{2.71+4.66 B^{1 / 2}}{t \times E \times P \times 2.22}$

where

B = the total correction in counts (Compton, background, blanks, etc., for the same counting time)

$\mathrm{t}=$ the counting time in minutes

$\mathrm{E}=$ the counting efficiency as a fraction

$\mathrm{P}=$ the gamma-ray emission probability for the particular gamma ray being measured

$2.22=$ the $\mathrm{dpm} / \mathrm{pCi}$.

The figures in the left-hand column of each sample type give the same detection limits expressed in terms of $\mathrm{pCi}$ /unit weight or volume for the average sample sizes expected to be analyzed. Because the absolute detection limits must remain constant for a given counting time and efficiency, the detection limits in terms of concentrations become higher or lower as the sample size actually used in the analysis becomes smaller or larger. Table B-4 presents descriptions of environmental monitoring samples for gamma spectrometry analysis and counting conditions for stated detection limits. 
Table B-4. Description of RESP samples for gamma spectrometry analysis.

\begin{tabular}{|c|c|c|}
\hline Media & Sample Description & Counting Conditions \\
\hline $\mathrm{Air}$ & $\begin{array}{l}\text { Sampled at approximately } 4 \mathrm{cfm} \text { for } \\
2 \text { weeks on } 4 \text { in. Versapor } 1200 \mathrm{mem} \text { - } \\
\text { brane filters for a total of } 3 \times 10^{9} \mathrm{cc} \\
\text { per filter. }\end{array}$ & $\begin{array}{l}\text { Monthly composite samples of two 4-in. } \\
\text { filters containing a total of about } 6 \times \\
10^{9} \mathrm{cc} \text { of air are held flat over the detec- } \\
\text { tor and counted for } 12 \text { to } 16 \text { hours } \\
\text { depending on the detector system used. }\end{array}$ \\
\hline Water & $\begin{array}{l}\text { 4-L collapsible polyethylene container } \\
\text { containing } 25 \mathrm{~mL} \text { of conc. } \mathrm{HNO}_{3} \text { and } \\
\text { two Whatman ashless filter paper tablets } \\
\text { for } 4000 \mathrm{~mL} \text { of water. }\end{array}$ & $\begin{array}{l}\text { The sample is shaken vigorously to dis- } \\
\text { lodge all material from the sides and bot- } \\
\text { tom of the container and filter. The fil- } \\
\text { trate is transferred to a } 4 \mathrm{~L} \text { Marinelli bea- } \\
\text { ker and counted for } 16 \text { hours. The filter } \\
\text { and paper pulp are also counted for } \\
16 \text { hours in contact with detector. Sample } \\
\text { size, } 4000 \mathrm{~mL} \text {. }\end{array}$ \\
\hline Soil & $\begin{array}{l}\text { 16-oz squat jar filled to the bead below } \\
\text { the threads after settling. }\end{array}$ & $\begin{array}{l}\text { The sample is counted in the squat jar } \\
\text { for } 2 \text { hours with the jar being rotated as } \\
\text { close to the detector as possible. Sample } \\
\text { size approximately } 700 \mathrm{~g} \text {. }\end{array}$ \\
\hline Vegetation & $\begin{array}{l}\text { 16-oz squat jar filled to the bead below } \\
\text { the threads after settling. }\end{array}$ & $\begin{array}{l}\text { The dry sample is counted in the squat } \\
\text { jar for } 16 \text { hours with the jar being rotated } \\
\text { as close to the detector as possible. Sam- } \\
\text { ple size about } 150 \mathrm{~g} \text {, average. }\end{array}$ \\
\hline
\end{tabular}




\section{Appendix C}

Statistical Analysis Methods

C-1 
C-2 


\section{Appendix C}

\section{Statistical Analysis Methods}

\section{General}

This appendix summarizes the statistical methods used to analyze of the Radiological and Environmental Surveillance Program (RESP) airborne particulate and penetrating radiation data presented in the text of this report. Specifically, these methods are used for determining long-term trends and for determining differences between groupings (i.e., by monitor type, by facility, or by season) of data are addressed. These methods are detailed in Blackwood. ${ }^{1}$

\section{Data Pretreatment and Validation}

Prior to using data for comparative purposes, data are prescreened to ensure no gross data errors occur, such as transcription errors, missing values, out of range data points, and data points that do not meet other specific criteria. Initial screening includes eliminating data from instruments that do not meet the minimum required operating characteristics as specified in the data quality objectives.

Once the basic checks for errors and operating criteria are complete, the data are screened for outliers. Graphical techniques (e.g., probability plots, stem and leaf plots, box plots, and other exploratory data analysis techniques) are the primary tools used for detecting potential data outliers. In cases where outliers are traceable to a specific error, a corrected value may be used to replace the outlier. If no correction is possible, then the point is deleted from the data set; however, outliers with unattributable causes are rarely eliminated from the data set. Such outliers may be truly accurate data measurements indicative of unusual but important phenomena. In these cases, two sets of analyses are performed with the outliers, one with and one without, which provides results that can be compared.

\section{Trend Analysis}

To visually evaluate long-term trends, cumulative data are presented graphically. For RESP gross-alpha and gross-beta air data, concentration data for specific locations are plotted over the year of interest. Four concentration versus time plots are provided, separated by monitor and analysis type. Within each plot, data are smoothed using polynomial smoothing, and lines indicating the polynomial fit to the data are presented to provide a general indication of the trend in concentrations over the year.

For TLD data, cumulative six-month exposure data from specific locations, with background (or distant community) data excluded, are plotted over time. All historical data are smoothed and plotted on a logarithmic scale to give an indication of the trend over time.

\section{Comparisons Between Groupings}

\section{Penetrating Radiation Data from TLDs}

Differences in yearly TLD data, either seasonally or by facility location, are analyzed using the nonparametric Kruskal-Wallis test for differences in medians. Nonparametric analyses are performed since the data are not expected to follow a normal distribution. Changes among groups are considered to be statistically significant if the p-value, associated with the null hypothesis, is less than 0.05 . The 
null hypothesis is that the different samples in the groupings were from the same distribution or from distributions with the same median.

The statistical significance of changes seen in median exposure values from the previous year to the current year is determined by facility. Facility groupings consist of background (or distant community) data, as well as individual RESP locations. Since TLDs are changed out every six months, the significance of the differences in median seasonal exposure values (either spring or fall) is also of interest.

Box and whisker plots are used to graphically display the differences in median values between groups (either by facility or season). For each grouping, the median value is shown on the box and whisker plots, along with a box indicating the 25th to 75th percentile range. The whiskers on the plots indicate the (non-outlier) minimum and maximum values within each grouping. For the box and whisker plots, outliers are defined as those data values greater than 1.5 times the range of the box.

\section{Airborne (Gross-Alpha and Gross-Beta) Data}

Differences in year-to-year median concentrations for facility groupings of airborne data are also analyzed using the Kruskal-Wallis test for differences in medians. Data from the current year are grouped by facility for each contaminant and monitor type (i.e., gross-alpha or gross-beta and $\mathrm{PM}_{10}$ or SP monitor) and compared to the same groupings using data from the previous year. Differences in groupings are also graphically displayed using the box and whisker plots discussed above. 


\section{REFERENCES}

1. Blackwood, L. G., Statistical Analysis Methods for Data From the EG\&G Idaho Environmental Unit Radiological Environmental Surveillance Program, EG\&G Idaho, Inc., EGG-0-RAAM-10785, 1993. 


\section{Appendix D}

\section{Environmental Standards}

D-1 


\section{D-2}




\section{Appendix D}

\section{Environmental Standards}

\section{RADIOLOGICAL SURVEILLANCE AT WASTE MANAGEMENT FACILITIES}

Radionuclide concentrations in air and groundwater samples collected at MWSF, RWMC, and WERF are compared with Derived Concentration Guide (DCG) values for air and water. ${ }^{1}$ The DCG values listed are provided as reference values for conducting radiological protection programs at operational DOE facilities and sites.

Table D-1 lists applicable DCGs. The DCGs represent the concentrations of radioactivity in air inhaled or water ingested continuously during a year that resulted in a 100-mrem, 50-year committed effective dose equivalent (EDE). The DCGs are used as a point of reference only. Comparing individual measurements to the DCGs gives the maximum dose a person could receive at the location where the sample was collected, given the following two assumptions: (1) the concentration was at the DCG level continuously for the entire year, and (2) the person receiving the exposure was at that location for the entire year, continually drinking the water or inhaling the air. In practice, DCGs are rarely, if ever, exceeded for even a short period of time during the year. In addition, the radionuclide concentration at any area accessible to the public will be even less due to the dispersion from the facility boundary (where the sample was collected) to the site boundary (the closest location where the public has unrestricted access). ${ }^{2}$

Table D-2 lists environmental concentration guidelines for the radionuclides in soil that are most likely to be found in environmental samples collected at the RWMC. The concentration guides in Table D-2 are based on a homestead scenario. This scenario considers the radiation dose to the homesteader from inhalation and ingestion of radionuclides, as well as external radiation. Since the hypothetical homesteader is assumed to live on a uniformly contaminated area, that is large enough for subsistence farming. This scenario results in very conservative concentration guides. The homestead scenario overestimates the actual doses that would be received by off-homestead individuals from radionuclides in soil at the RWMC.

\section{GROUNDWATER}

The environmental regulations that apply to the Drinking Water Program are as follows: the Federal Safe Drinking Water Act, ${ }^{3}$ Code of Federal Regulations (40 CFR Parts 141-143);4,5,6 the Idaho Regulations for Public Drinking Water Systems, IDAPA 16.01.08000-.08999;7 DOE Order 5400.5; ${ }^{8}$ and Environmental Compliance Planning Manual. ${ }^{9}$

In addition to the eighteen regulated VOCs (see Table D-3), unregulated organic compounds are monitored and reported. 
Table D-1. Derived Concentration Guides.

\begin{tabular}{|c|c|c|}
\hline \multirow[b]{2}{*}{ Radionuclide } & \multicolumn{2}{|c|}{ DCGs for the public ${ }^{a, b}$} \\
\hline & $\begin{array}{l}\text { DCG for air } \\
(\mu \mathrm{Ci} / \mathrm{mL})\end{array}$ & $\begin{array}{l}\text { DCG for water } \\
(\mu \mathrm{Ci} / \mathrm{mL})\end{array}$ \\
\hline $\mathrm{H}-3$ & $1 \mathrm{E}-7$ & $2 \mathrm{E}-3$ \\
\hline $\mathrm{Sc}-46$ & $6 \mathrm{E}-10$ & $2 \mathrm{E}-5$ \\
\hline $\mathrm{Cr}-51$ & $5 \mathrm{E}-8$ & $1 \mathrm{E}-3$ \\
\hline $\mathrm{Mn}-54$ & $2 E-9$ & 5 E-5 \\
\hline $\mathrm{Co}-58$ & 2 E-9 & $4 \mathrm{E}-5$ \\
\hline $\mathrm{Fe}-59$ & 8 E-10 & $2 E-5$ \\
\hline $\mathrm{Co}-60$ & $8 \mathrm{E}-11$ & $5 \mathrm{E}-6$ \\
\hline $\mathrm{Zn}-65$ & $6 \mathrm{E}-10$ & $9 \mathrm{E}-6$ \\
\hline Sr-90 & 9 E-12 & $1 \mathrm{E}-6$ \\
\hline $\mathrm{Nb}-95$ & 3 E-9 & $6 E-5$ \\
\hline $\mathrm{Zr}-95$ & $6 \mathrm{E}-10$ & $4 E-5$ \\
\hline $\mathrm{Ru}-103$ & 2 E-9 & $5 \mathrm{E}-5$ \\
\hline $\mathrm{Ru}-106$ & $3 \mathrm{E}-11$ & $6 \mathrm{E}-6$ \\
\hline $\mathrm{Ag}-110 \mathrm{~m}$ & $2 \mathrm{E}-10$ & $1 \mathrm{E}-5$ \\
\hline $\mathrm{Sb}-125$ & 1 E-9 & 5 E-5 \\
\hline $\mathrm{I}-129$ & $7 \mathrm{E}-11$ & $5 \mathrm{E}-7$ \\
\hline $\mathrm{I}-131$ & $4 E-10$ & $3 \mathrm{E}-6$ \\
\hline Cs-134 & 2 E-10 & $2 \mathrm{E}-6$ \\
\hline Cs-137 & $4 \mathrm{E}-10$ & $3 \mathrm{E}-6$ \\
\hline Ce-141 & $1 E-9$ & $5 \mathrm{E}-5$ \\
\hline Ce-144 & 3 E-11 & $7 \mathrm{E}-6$ \\
\hline Eu-152 & $5 \mathrm{E}-11$ & $2 E-5$ \\
\hline Eu-154 & $5 \mathrm{E}-11$ & $2 E-5$ \\
\hline Ra-226 & $1 \mathrm{E}-\dot{12}$ & $1 \mathrm{E}-7$ \\
\hline $\mathrm{Pu}-238$ & 3 E-14 & $4 E-8$ \\
\hline Pli-239c & $2 \mathrm{E}-14$ & $3 \mathrm{E}-8$ \\
\hline Am-241 & 2 E-14 & $3 \mathrm{E}-8$ \\
\hline U-235 & $1 \mathrm{E}-13$ & $6 E-7$ \\
\hline $\mathrm{U}-238$ & $1 \mathrm{E}-13$ & $6 \mathrm{E}-7$ \\
\hline Gross Alphac & $2 \mathrm{E}-14$ & \\
\hline Gross Betac & $9 E-12$ & \\
\hline
\end{tabular}

a. This table contains the air and water DCGs based on concentrations that could be continuously inhaled or ingested, respectively, and do not exceed an effective dose equivalent of $100 \mathrm{mR} / \mathrm{yr}$.

b. DCGs apply to radionuclide concentrations in excess of those occurring naturally or due to fallout.

c. The DCGs of Pu-239 and Sr-90 are the most restrictive for alpha- and beta-emitting nuclides, respectively, and are appropriate to use for gross alpha and gross beta DCGs. 
Table D-2. Environmental Concentration Guidelines for common radionuclides found in environmental soil samples collected at the RWMC.

\begin{tabular}{|c|c|}
\hline Radionuclide & $\begin{array}{c}\text { Environmental } \\
\text { concentration } \\
\text { guides for soil } \\
(\mu \mathrm{Ci} / \mathrm{g})\end{array}$ \\
\hline $\mathrm{Mn}-54$ & $4 \mathrm{E}-6$ \\
\hline $\mathrm{Co}-58$ & 4 E-6 \\
\hline $\mathrm{Co}-60$ & 1 E-6 \\
\hline $\mathrm{Ru}-106$ & $2 E-5$ \\
\hline Sb-125 & 8 E-6 \\
\hline Cs-134 & 2 E-6 \\
\hline Cs-137 & 6 E-6 \\
\hline $\mathrm{Ce}-144$ & $6 E-5$ \\
\hline Eu-152 & 3 E-6 \\
\hline Am-241 & $4 \mathrm{E}-5$ \\
\hline Sr-90 & $6 \mathrm{E}-6$ \\
\hline $\mathrm{U}-232$ & $2 \mathrm{E}-6$ \\
\hline U-233 & $2 E-4$ \\
\hline $\mathrm{U}-234$ & $2 E-4$ \\
\hline U-235 & $2 E-5$ \\
\hline & $\cdot$ \\
\hline U-238 & $1 \mathrm{E}-4$ \\
\hline $\mathrm{Pu}-238$ & $8 \mathrm{E}-5$ \\
\hline $\mathrm{Pu}-239,-240$ & $8 \mathrm{E}-5$ \\
\hline
\end{tabular}

a. See Reference 2. Concentrations correspond to a 50-yr dose commitment of $100 \mathrm{mrem} / \mathrm{yr}$ to a homesteader beginning in the first year after release of facility. This concentration assumes uniform contamination of an area adequate for subsistence farming. 
Table D-3. Standards for volatile organic compounds.

\begin{tabular}{|c|c|}
\hline REGUL & $\begin{array}{l}\text { is } \\
\text { num contaminant level } \\
(\mathrm{mg} / \mathrm{L})\end{array}$ \\
\hline Benzene & 0.005 \\
\hline Vinyl Chloride & 0.002 \\
\hline Carbon Tetrachloride & 0.005 \\
\hline 1,2-Dichloroethane & 0.005 \\
\hline Trichloroethylene & 0.005 \\
\hline 1,1-Dichloroethylene & 0.007 \\
\hline 1,2,4-Trichlorobenzene & 0.07 \\
\hline 1,1,1-Trichloroethane & 0.200 \\
\hline 1,1,2-Trichloroethane & 0.005 \\
\hline para-Dichlorobenzene & 0.075 \\
\hline cis-1,2-Dichloroethylene & 0.07 \\
\hline 1,2-Dichlorpropane & 0.005 \\
\hline Dichloromethane & 0.005 \\
\hline Ethylbenzene & 0.7 \\
\hline Monochlorobenzene & 0.1 \\
\hline O-Dichlorobenzene & 0.6 \\
\hline Styrene & 0.1 \\
\hline Tetrachloroethylene & 0.005 \\
\hline Toluene & 1.0 \\
\hline Trans-1,2-Dichloroethylene & 0.1 \\
\hline Xylenes (total) & 10.0 \\
\hline \multicolumn{2}{|c|}{ UNREGULATED VOCs WITH NO MCL } \\
\hline Chloroform & O-Chlorotoluene \\
\hline Chlorobenzene & P-Chlorotoluene \\
\hline Bromodichloromethane & Bromobenzene \\
\hline Chlorodibromomethane & 1,3-Dichloropropene \\
\hline Bromoform & 1,2,4-Trimethylbenzene \\
\hline M-Dichlorobenzene & 1,2,4-Trichlorobenzene \\
\hline 1,1-Dichloropropane & 1,1-Dichloroethane \\
\hline 1,1,1,2-Tetrachloroethane & 1,1,2,2-Tetrachloroethane \\
\hline Chloroethane & 1,3-Dichloropropane \\
\hline 2,2-Dichloropropane & Chloromethane \\
\hline Bromomethane & Isopropylbenzene \\
\hline 1,2,3-Trichlorobenzene & Tert-Butylbenzene \\
\hline N-Butylbenzene & SEC-Butylbenzene \\
\hline N-Propylbenzene & Fluorotrichloromethane \\
\hline Naphthalene & Dichlorodifluoromethane \\
\hline Hexachlorobutadiene & Bromochloromethane \\
\hline 1,3,5-Trimethylbenzene & 1,2,3-Trichloropropane \\
\hline P-I propyltoluene & \\
\hline
\end{tabular}


The INEL is a nuclear facility, which implies that radiological contamination of the drinking water is possibile. Because of the possibility of radiological contaminants, Lockheed Martin Idaho monitors for gross alpha, gross beta, and tritium (see Table D-4), as recommended in IDAPA 16.01.08100,06.

Table D-4. Applicable radiological drinking water standards.

\begin{tabular}{lc}
\hline Parameter & $\begin{array}{c}\text { Maximum contaminant level } \\
(\mathrm{pCi} / \mathrm{L})\end{array}$ \\
\hline Gross Alpha & 15 \\
Gross Beta & 50 \\
Tritium & 20,000 \\
\hline
\end{tabular}




\section{REFERENCES}

1. DOE Order 5400.5, "Radiation Protection of the Public and the Environment," Department of Energy, February 8, 1990.

2. EG\&G Idaho, Inc., Development of Criteria for Release of Idaho National Engineering Laboratory Sites Following Decontamination and Decommissioning, EGG-2400, August 1986.

3. Public Law 99-339, Safe Drinking Water Act Amendments of 1986, June 19, 1986.

4. Code of Federal Regulations, 40 CFR 141, "National Primary Drinking Water Standards," Office of the Federal Register, July 1, 1992.

5. Code of Federal Regulations, 40 CFR 142, "National Primary Drinking Water Regulations Implementation," Office of the Federal Register, July 1, 1992.

6. Code of Federal Regulations, 40 CFA 143, "National Secondary Drinking Water Regulations," Office of the Federal Register, July 1, 1992.

7. Idaho Regulations for Public Drinking Water Systems, IDAPA 16.01.08000-.08999, December 5, 1992.

8. DOE Order 5400.5, Change 2, "Radiation Protection of the Public and the Environment," U.S. Department of Energy, January 7, 1993.

9. Environmental Compliance Planning Manual at the Idaho National Engineering Laboratories, Volumes I, II, and III, U.S. Department of Energy Idaho Operations Office, April 1991. 


\section{D-10}

